\title{
SHORT NOTES ON ALASKAN GEOLOGY 1991
}

Professional Report 111
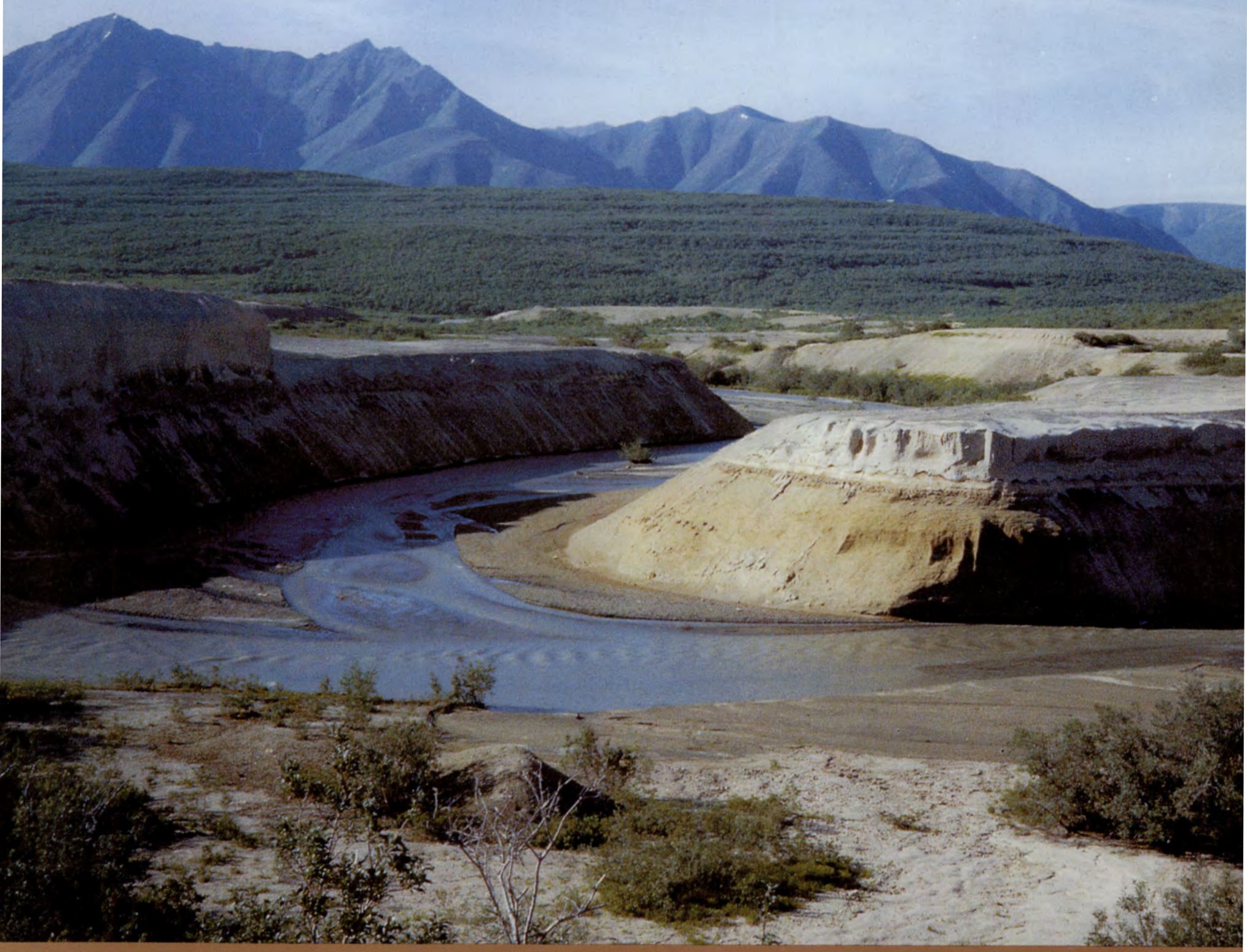

Published by

STATE OF ALASKA

DEPARTMENT OF NATURAL RESOURCES

DIVISION OF GEOLOGICAL \& GEOPHYSICAL SURVEYS

THOMAS E. SMITH

STATE GEOLOGIST

1991 


\section{EDITORIAL POLICY}

"Short Notes on Alaskan Geology" is a collection of brief contributions describing recent geological investigations of limited scope. This publication is widely distributed to a state, national, and international audience that represents industry, academia, government agencies, and the general public. Manuscripts are accepted for consideration with the understanding that they have not been previously published and are not being submitted for publication elsewhere, that all persons listed as authors have given their approval for submission of the paper, and that any person cited as a source of personal communication has approved such a citation. Authors are encouraged to suggest appropriate reviewers and provide reviewer's telephone numbers.

\section{SUBMISSION OF MANUSCRIPTS}

Authors should submit three paper copies of their draft manuscripts to Short Notes Editor, Alaska Division of Geological and Geophysical Surveys, 794 University Avenue, Suite 200, Fairbanks, Alaska 99709-3645. Contributors should retain one copy of all materials submitted; DGGS is not responsible for materials lost in the mail. In general, articles are limited to no more than 10 manuscript pages (about 2,000 words of text), including references, figures, and tables.

All draft manuscripts will be examined and approved by the DGGS editor and at least two technically-competent reviewers. After technical reviews are completed, copies of review forms and reviewed manuscript pages will be returned to the author for revision (if required) and resubmittal. Conflicts between reviewers and authors must be resolved to the satisfaction of the DGGS editor before final acceptance of manuscripts. Final submittals must be provided as double-spaced paper copy and on high-density PC diskette (Microsoft Word or Word Perfect). Questions should be directed to the DGGS editor [(907) 474-7147] prior to mailing. Substantial changes by the authorwhether scientific or editorial - are not permitted after the manuscript is in galley form.

\section{TEXT PREPARATION}

Manuscripts should be double spaced with 1-inch margins on all sides. The title page should include the title of the article and the name(s) and affiliation(s) of the author(s). Because of the brevity of Short Notes articles, tables of contents, lists of illustrations, and abstracts are not accepted. Words to be printed in italics should be typed in italics.

Specific guidelines for units of measure, abbreviations, references, etc. are provided in "Suggestions to Authors of Reports of the United States Geological Survey (7th edition)" or "Government Printing Office Style Manual 1973." Potential authors are also encouraged to consult the latest issue of Short Notes for information.

\section{PREPARATION OF ILLUSTRATIONS}

All figures should be provided in camera-ready form. Computer-generated illustrations are acceptable. Line figures are generally published in black and white, but color art may be accepted with the understanding that the author will pay additional costs (color separation and printing) for colored figures. Current page-cost information can be obtained from the DGGS editor. Maximum size for figures is 6.5 by 8.5 inches. Large foldouts are not accepted. 


\section{SHORT NOTES ON ALASKAN GEOLOGY 1991}

\section{Edited by Richard D. Reger}

Cover and layout designed by Ann-Lillian C. Schell

Professional Report 111

Recent research on Alaskan geology 


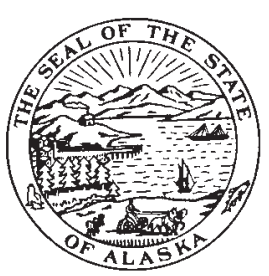

STATE OF ALASKA Walter J. Hickel, Governor

DEPARTMENT OF NATURAL RESOURCES Harold C. Heinze, Commissioner

DIVISION OF GEOLOGICAL \& GEOPHYSICAL SURVEYS

Thomas E. Smith, Director and State Geologist

DGGS publications may be inspected at the following locations. Address mail orders to the Fairbanks office.

\footnotetext{
Alaska Division of Geological \& Geophysical Surveys

Attn: Publications

794 University Avenue, Suite 200

Fairbanks, Alaska 99709-3645

400 Willoughby Avenue, 3rd floor Juneau, Alaska 99801

U.S. Geological Survey Earth Science Information Center 605 West 4th Avenue, Room G84 Anchorage, Alaska 99501-2299

4230 University Drive, Room 101 Anchorage, Alaska 99508
}

This publication, released by the Division of Geological \& Geophysical Surveys, was produced and printed in Delta Junction, Alaska at a cost of \$8 per copy. Publication is required by Alaska Statute 41, "to determine the potential of Alaskan land for production of metals, minerals, fuels, and geothermal resources; the location and supplies of groundwater and construction materials; the potential geologic hazards to buildings, roads, bridges, and other installations and structures; and shall conduct such other surveys and investigations as will advance knowledge of the geology of Alaska."

\section{FOREWORD}

The Division of Geological and Geophysical Surveys is pleased to reintroduce the series "Short Notes on Alaskan Geology." In producing this edition, we are indebted to Dr. Robert B. Forbes, former State Geologist, for providing much of the enthusiasm and impetus for continuing the "Short Notes" series. This unique source of brief but informative papers on a wide variety of topics related to geology in Alaska represents the works of earth scientists in state and federal agencies, universities, and industry. Because of their brevity and limited scope, many of the papers in this series might not be accepted for publication in journals with more national and international focus. Nonetheless, the subject matter is very useful to those interested in learning more about the geology of Alaska.

The new Short Notes series mirrors changes in DGGS that have resulted from increased technical capabilities but smaller budgets and a reduced staff. This 1991 issue, the sixth and largest in the series, represents a transition from labor-intensive production techniques of the past to more efficient computer graphics and desktop-publishing methods. A smaller staff has meant that more people became involved in planning, coordination, editing, formatting, and preparation than before. More responsibility for manuscript preparation was given to authors, who produced initial drafts, made changes suggested by reviewers and the editor, and ultimately provided final draft manuscripts on PC diskettes. Author-generated, camera-ready figures hastened publication considerably. Much innovative thinking and hard work by many talented folks have greatly improved the appearance and readability of Short Notes and will heighten reader interest. For the first time, computer-generated colored figures are part of the format. We anticipate that the instructions for contributing authors that are printed inside the front and back covers will encourage future contributions from inside and outside of DGGS.

All of these changes are intended to improve service to authors and to our readership. We hope that the response will be greater interest among the entire earth-science community and increased participation in this unique series.

Thomas E. Smith State Geologist

Front cover: Light-colored ash of the 1912 eruption of Mt. Katmai overlying oxidized Lethe tephra along lower Windy Creek, Katmai National Park. Photograph by DeAnne S. Pinney. 


\section{CONTENTS}

Tin placers associated with the downcutting of fissure basalts, Ray River drainage, Alaska

James C. Barker

Geology and geochemistry of the Gagaryah barite deposit, western Alaska Range, Alaska

Thomas K. Bundtzen and Wyatt G. Gilbert.

Geology and geochemistry of Tatlawiksuk Hot Springs, a newly discovered geothermal area in western Alaska

Thomas K. Bundtzen, Shirley E. Liss, and Ellen E. Harris.

Geology and geochemistry of the Sleitat Mountain tin deposit, southwestern Alaska

Roger E. Burleigh

Native mercurian-silver, silver, and gold nuggets from Hunter Creek, Alaska

Robert B. Forbes and Bart Cannon

Late Pleistocene volcanic deposits near the Valley of Ten Thousand Smokes, Katmai National

Park, Alaska

DeAnne S. Pinney and James E. Begét.

Deglaciation of the Allison-Sawmill Creeks area, southern shore of Port Valdez, Alaska

Richard D. Reger

Dating Holocene moraines of Canwell Glacier, Delta River valley, central Alaska Range

Richard D. Reger and Troy L. Péwé.....

Gilead sandstone, northeastern Brooks Range, Alaska: An Albian to Cenomanian marine clastic succession

Rocky R. Reifenstuhl

Kikiktat Mountain klippe: A link between the Copter Peak and Nuka Ridge allochthons, northcentral Brooks Range, Alaska

Diana N. Solie and Charles G. Mull....

Sample media useful for a systematic geochemical survey of upper Valdez Creek, Alaska

Milton A. Wiltse, Karen H. Clautice, and Alfred G.Sturmann 


\title{
TIN PLACERS ASSOCIATED WITH THE DOWNCUTTING OF FISSURE BASALTS, RAY RIVER DRAINAGE, ALASKA
}

\author{
By \\ James C. Barker ${ }^{1}$

\section{BEDROCK GEOLOGY}

\section{INTRODUCTION}

Alluvial cassiterite is widespread in river gravels and high-level terraces in the Ray River drainage, an area of low, unglaciated hills immediately north of the Yukon River (fig. 1). Anomalous tin was first detected in stream-sediment samples about $65 \mathrm{~km}$ northwest of the Fort Hamlin Hills by Herreid (1969). Further investigations of tin mineralization initiated in 1975 by Barker and Foley (1986) identified significant placers and lodes in the vicinity of the Sithylemenkat pluton (fig. 1) and indicated that other plutons in the area were favorable sites. In 1983, a heavy-mineral survey of the pipeline corridor north of Livengood identified several areas of anomalous tin, including a cluster of sites near the inferred northern extent of the Fort Hamlin Hills pluton (Barker, 1983).

Beginning in 1985, the northern Fort Hamlin Hills and the Ray River watershed were studied as part of the U.S. Bureau of Mines Strategic Minerals Program. In this area, as much as $30 \mathrm{~m}$ of alluvium containing cassiterite was deposited over fissure-flood basalts that are up to 75 $\mathrm{m}$ thick in graben-like depressions. Subsequent erosion of cassiterite-bearing sediments also produced placers in modern fluvial terraces.

\section{METHODOLOGY}

Heavy-mineral samples were collected from 63 sites. In addition, seven auger holes were drilled using a helicopter-portable, 6.4-cm-diam, solid-stem auger drill. Sampling and other errors in this technique are unevaluated, so reported tin grades should be considered as minimum values.

Tin content of heavy-mineral samples was determined by the X-ray fluorescence method. Values exceeding the 20,000-ppm upper detection limit were reassayed after total multi-acid digestion. Following analysis, the tin grade of each sample site was calculated in metric units. ${ }^{2}$

\footnotetext{
${ }^{1}$ Formerly of U.S. Bureau of Mines, Alaska Field Operations Center, Fairbanks, Alaska 99709.

${ }^{2}$ For conversion, $1 \mathrm{lb}$ of tin per $/ \mathrm{yd}^{3}$ equals $593 \mathrm{~g} / \mathrm{m}^{3}$.
}

The project area includes the Ray River and Fort Hamlin Hills plutons and parts of the Coal Creek and Sithylemenkat plutons (fig. 1). These plutons intrude metasedimentary rocks of Paleozoic age that form part of the Ruby terrane, a broad northeast-striking belt of crystalline rock in northcentral Alaska (Arth and others, 1989). To the south, mafic volcanic rocks, gabbro, and chert of the Tozitna terrane are juxtaposed against the Ruby terrane in the Ray River area along a poorly exposed, major thrust fault (fig. 1).

The oldest rocks in the area are quartz-mica schist, light-colored quartzite, and phyllite of Paleozoic age or older. White quartz and quartz-carbonate veins and quartz stockworks are abundant, particularly in the phyllite. Overlying the older rocks is a quartzite-limestone unit of Paleozoic age. These rocks all exhibit thermal alteration in the vicinity of granitic intrusions. Rocks of the broad-domed granitic plutons generally underlie all higher terrain. They are separated by generally flat flows of fissure basalt, Tertiary sedimentary rocks, and unconsolidated sediments of Quaternary age that are preserved in poorly defined graben-like basins. Geothermal springs and seeps are mapped on the margins of the basins (Barker, 1991).

All plutons in the map area are Cretaceous (Arth and others, 1989). These multi-phased bodies are composed mainly of coarse, equigranular-to-porphyritic, K-sparbiotite quartz monzonite and granite. Subordinate phases include aplite, fine-grained tourmaline-bearing quartz monzonite, fine-grained quartz porphyry, and tourmaline pegmatite. Major-oxide analyses indicate that the plutons are peraluminous, calc-alkaline granite (Barker, 1991). These plutons are considered to be among more than a dozen similar calc-alkaline plutons of the Cretaceous-age Ruby batholith (Arth and others, 1989). Neither the Ray River nor the Fort Hamlin Hills plutons are dated; however, compositional similarities with the Sithylemenkat pluton (106 $\pm 3 \mathrm{Ma}$ ), the Ray Mountains pluton (109-112 $\mathrm{Ma})$ to the west, and the Hodzana pluton (112 Ma) to the north indicate similar ages (Arth and others, 1989).

Fine-grained intrusive phases exhibit locally intense tourmalization, silicification, and variable sericitization. Alteration features are most readily observed in outcrops 


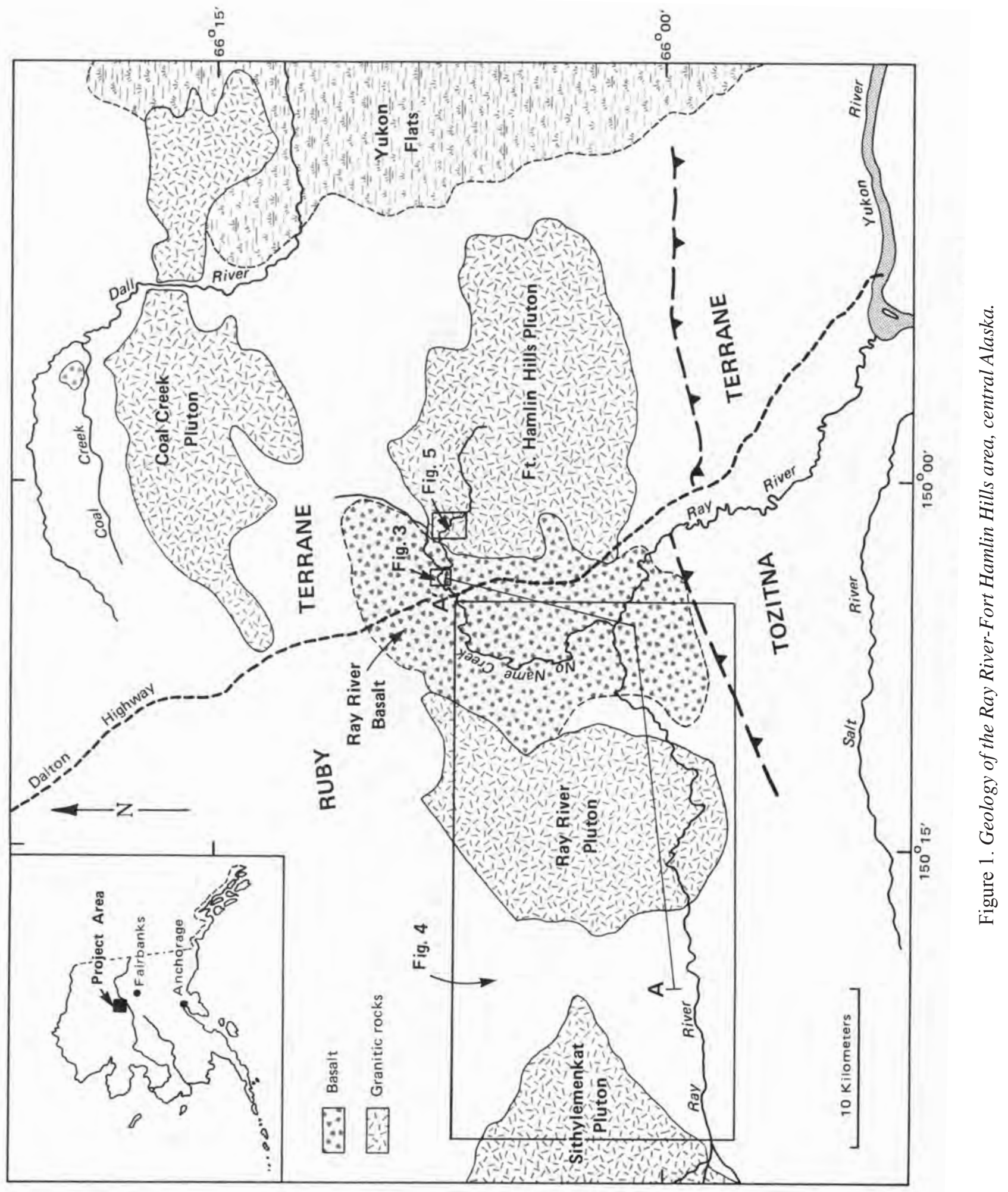


near the south fork of No Name Creek (fig. 1), and similar rubble is present in the road cut $5.5 \mathrm{~km}$ south of No Name Creek. The widespread abundance of quartz and quartz-tourmaline pebbles in high-level terrace gravels proximal to the northern and eastern Fort Hamlin Hills may indicate that tourmaline alteration and silicification are much more extensive than is indicated by surface exposures.

Coal-bearing sedimentary rocks of Tertiary-age (Ts) are exposed in outcrops or rubble at several places along the Ray and Dall Rivers (fig. 2). This unit is composed of carbonaceous volcaniclastic mudstone with volcanic-ash beds, arkosic sandstone and conglomerate, and lignitic coal. Coal-bearing strata overlie an upwardfining sequence of quartzose pebble conglomerate and sandstone. Pieces of coal float up to $0.5 \mathrm{~m}$ thick are present on gravel bars of the Ray River, indicating that Tertiary rocks underlie the valley floor. These Tertiary rocks are probably preserved in a north-striking graben between the Ray River and Fort Hamlin plutons. The Ts unit was primarily deposited during the early to middle Tertiary. A K-Ar date for a volcanic-ash bed overlying the coal implies an Eocene date of $38.6 \pm 1.6 \mathrm{Ma}$ (Barker, 1981). The most complete section of Tertiary sediments is exposed in the Ray River bluff $3 \mathrm{~km}$ above the mouth of No Name Creek. There, a 15-m-thick sequence of coaly tuff, carbonaceous tuff with interstitial masses of vitranite, coal, arkosic sands, and semi-consolidated, white-weathering fluvial gravels, is overlain by $60 \mathrm{~m}$ of basalt flows.

Horizontal basalt lavas $(\mathrm{Tb})$ form the youngest bedrock unit and are inferred to underlie about $156 \mathrm{~km}^{2}$ of the Ray River drainage. Textures range from vesicular to massive, and compositions are generally olivine basalt, but minor andesite is also present. Vesicules are locally filled with calcite, quartz, or native sulfur. Most commonly, the basalts are fine grained, but locally they have a medium-grained texture with lath-like plagioclase crystals randomly intergrown in a matrix of anhedral clinopyroxene. In an outcrop on Ray River $3 \mathrm{~km}$ upstream from No Name Creek at least three successive flows of fine-grained basalt feature columnar jointing between 500 and $725 \mathrm{ft}$ (150 and $220 \mathrm{~m}$ ) elevation.

Albanese (1987), who examined a basalt flow exposed in a roadcut $5 \mathrm{~km}$ south of No Name Creek, suggested a tholeiitic or alkaline affinity and compared the basaltic lavas to those formed in extensional systems. There are no exposed vents. Bases of the flows could only be examined at the Ray River outcrop, where they overlie coaly sedimentary rocks and exhibit a carbonaceous basal zone. A quenched-fracture stockwork, including thin $(20 \mathrm{~mm})$ selvages of obsidian and traces of phosphate staining, is exposed in the lowermost flow exposed at river level.
The basalt flows overlie Eocene sediments dated at $38.6 \pm 1.6 \mathrm{Ma}$, and a K-Ar date of $30.59 \pm 0.92 \mathrm{Ma}$ indicates that the basalt flows are Oligocene (Albanese, 1987).

\section{LATE TERTIARY AND QUATERNARY DEPOSITS}

The physiography of the Ray River area features rounded hills and wide, sediment-filled, semi-closed river basins. Valleys generally exhibit asymmetric cross sections with steeper north-facing slopes. Three mappable units of unconsolidated sediments document periods of sedimentation during the last $30 \mathrm{Ma}$ : pre-basalt, whiteweathering gravels (Twg); postbasalt high-level gravel terrace deposits $(\mathrm{Qg})$; and Holocene floodplain and terrace alluvium (Qt), which is reworked from the high-level terraces.

Prior to extrusion of mid-Tertiary basalt flows, relief in the area apparently was similar to or less than modern relief. Unit Twg is the product of erosion of surrounding crystalline highlands. It is thin ( $<4 \mathrm{~m}$ thick) and locally discontinuous. Clasts include subrounded to rounded white-weathering quartz, silicified schist, and hypabyssal felsic rock. These lithologies indicate that the granitic complexes were initially unroofed during deposition of the Twg unit.

High-level terrace gravel (unit Qg) includes a dissected array of terrace remnants perched $100 \mathrm{~m}$ or more above modern floodplains. Thickest deposits are found southeast of the Ray River pluton. Deposition of nearly $250 \mathrm{~km}^{2}$ of terrace gravel followed extrusion of basalt flows that blocked previous fluvial systems. The Qg gravel accumulated on the flows and other marginal upland surfaces. The unit is at least 15 to $30 \mathrm{~m}$ thick and is composed of fluvial sand and fine gravel (mostly quartz or granitic pebbles) crosscut by bouldery sandy gravel in paleochannels, which had patterns similar to present streams. The greater total volume of Qg material relative to the Twg unit indicates accelerated or prolonged erosion of highland crystalline bedrock subsequent to either local uplift or formation of nearby grabens. Later, the basalt flows and overlying terrace gravel were breached by stream incision. Consequently, most of the original terrace gravels are reworked and deposited (unit Qt) on the floodplains of modern streams and on low terraces.

\section{TIN PLACERS}

Cassiterite is most highly concentrated where alluvium has been most intensively reworked. Principal placers are present in alluvium of modern floodplains 


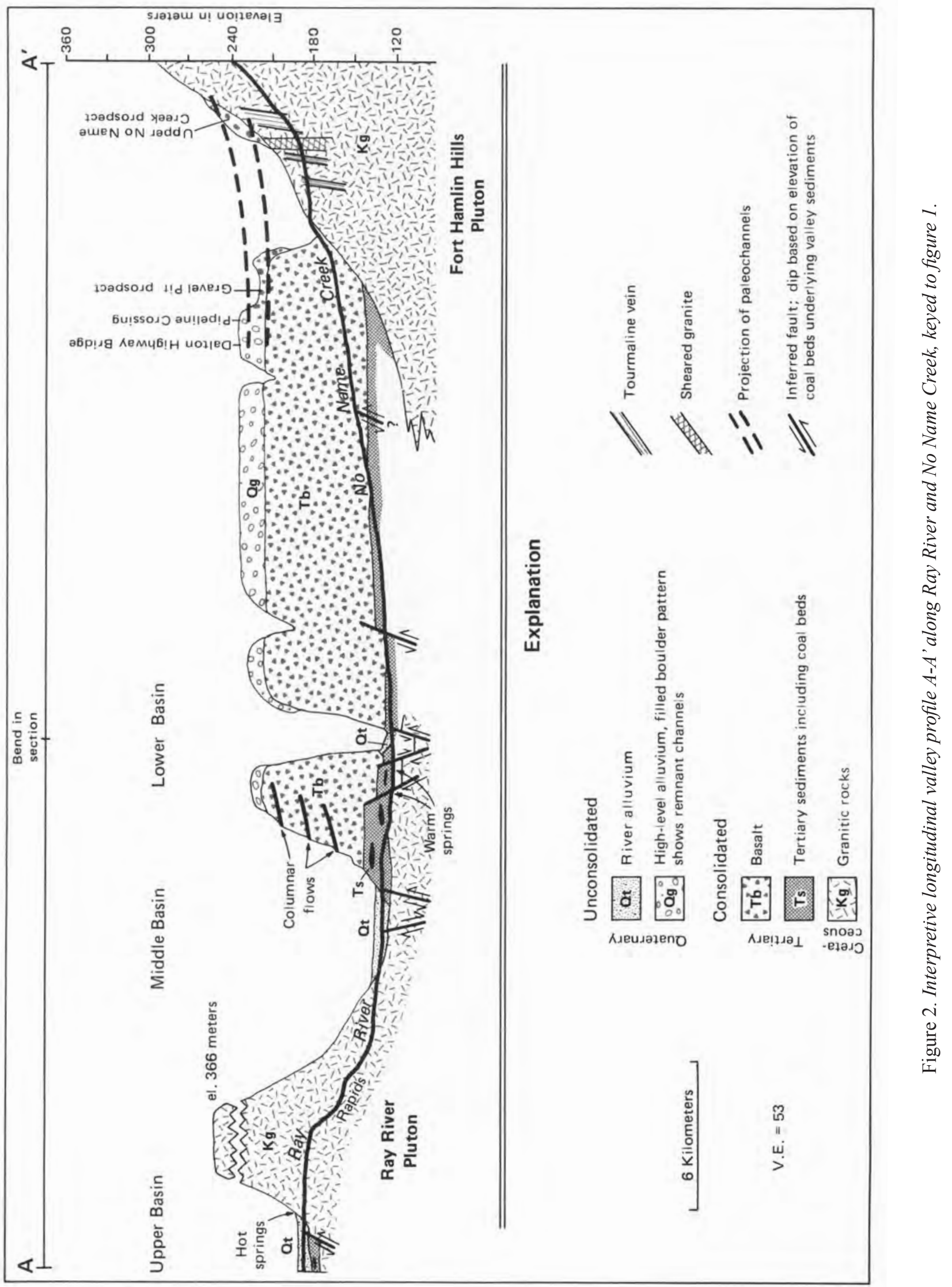


and in low fluvial terraces (Qt). Tin is also widespread but less concentrated in high-level terraces $(\mathrm{Qg})$ and is absent in the white-weathering gravels (Twg).

Placer tin is found in concentrations ranging from trace to about $25 \mathrm{~g} / \mathrm{m}^{3}$ throughout high-level terrace gravels $(\mathrm{Qg})$ but is more concentrated in paleochannels. Gravel pits and roadcuts associated with construction of the trans-Alaska pipeline (TAPS) expose several paleochannels containing approximately 19 to $150 \mathrm{~g} / \mathrm{m}^{3}$ of tin. Later reworking of the Qg unit and concentration of heavy minerals in the alluvium beneath modern floodplains in terrace gravels $(\mathrm{Qt})$ produced substantially higher tin values (18 to 3,706 g/m³) (Barker, 1991).

\section{Placer Tin in High-Level Terrace Gravel}

Sampling and mapping were conducted to test the distribution of placer tin in alluvium of high-level terraces near a gravel pit perched on basalt flows about 45 $m$ above No Name Creek (figs. 2 and 3). Unit Qg at this location consists of stratified, well-sorted sand, reworked grüss, and pebble gravel. Foreset bedding is common. At least two paleochannels of ancestral No Name Creek were identified in the pit. Poorly stratified paleochannel gravels are cobbly, consisting of clasts of granitic rock, quartz, and schist. Samples from these paleochannels contained between trace and $70 \mathrm{~g} / \mathrm{m}^{3}$ of tin; the higher value is from a single site in the southern channel where the gravel-bedrock contact is exposed (fig. 3). Astreambed gravel exposure immediately upstream from the pipeline crossing contained $100 \mathrm{~g} / \mathrm{m}^{3}$ of tin, which may indicate further concentration of heavy minerals in modern alluvium $(\mathrm{Qt})$.

Another gravel pit in weathered granite and high-level gravels $10.5 \mathrm{~km}$ south of the No Name Creek crossing exposes a cobbly, gravel-filled paleochannel cut into bedrock. The channel strikes east-southeast. A channel sample from the lowermost $1.2 \mathrm{~m}$ of the gravel contained the equivalent of $142 \mathrm{~g} / \mathrm{m}^{3}$ of tin.

A hilltop roadcut $4.8 \mathrm{~km}$ south of the No Name Creek bridge exposes another broad paleochannel feature on highly weathered basalt flows. This paleochannel is approximately $120 \mathrm{~m}$ wide and is filled with clay, basalt clasts, and pebble-cobble gravel predominantly composed of quartz-tourmaline and tourmaline granite. A single, 1.8-m long, vertical channel sample from the roadcut contained $113 \mathrm{~g} / \mathrm{m}^{3}$ of tin.

\section{Placer Tin in Holocene Alluvium}

Gravel exposed in low cutbanks along lower No Name Creek and Ray River was sampled at water level during canoe traverses. Typically, the gravel is loose

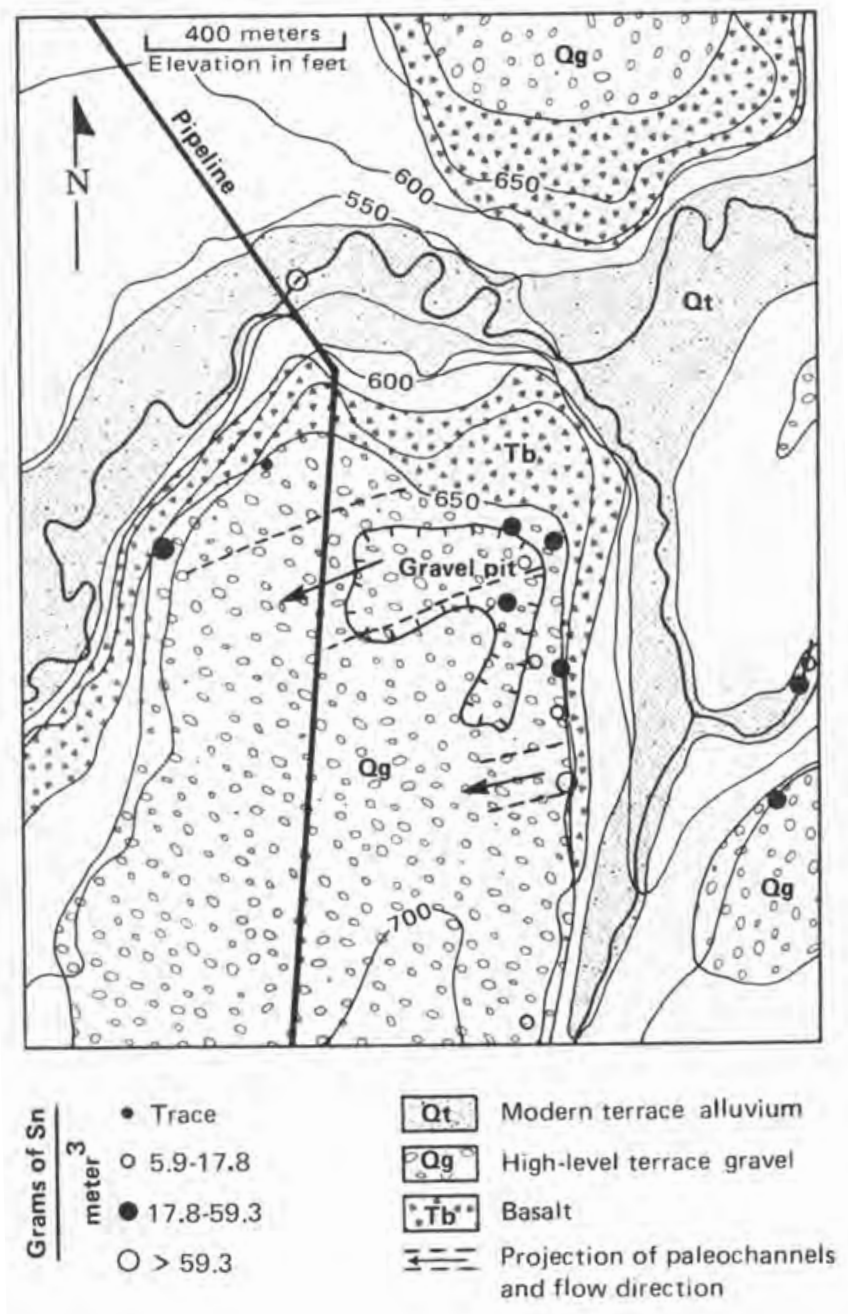

Figure 3. Geologic map of gravel pit south of No Name Creek showing heavy-mineral sample localities and projections of cassiterite-bearing paleochannels about 4-5 $m$ above present streams. Location of map area shown in figure 1.

and uncompacted and is composed of coarse sand with little to no fine fraction. Auger drilling indicates the siltfine sand fraction increases substantially at depths of 2 to $3 \mathrm{~m}$; however, mixed auger cuttings were unsuitable for seive analysis. Gravel in terraces and channel fills shallower than 2 to $3 \mathrm{~m}$ is unstratified and frequently reworked during floods, thereby precluding heavymineral accumulations and implying that heavy minerals are under represented in the samples. Consequently, surface samples may represent minimal heavy-mineral values per unit volume of gravel relative to the grade of heavy minerals expected in finer grained sediment below depths of 2 to $3 \mathrm{~m}$. Subsurface data are limited to only five auger holes drilled to depths of 3.4 to $7 \mathrm{~m}$ (fig. 4). None of the holes reached bedrock. Tin content in the 
auger cuttings, although diluted by surface gravel, averaged $77 \mathrm{~g} / \mathrm{m}^{3}$ (Barker, 1991). Screening the cuttings to -16 mesh $(1 \mathrm{~mm})$ produced a tin grade of $291 \mathrm{~g} / \mathrm{m}^{3}$, a likely upper grade limit for the section sampled. Data from random locations indicate cutbank gravel along the Ray River contains 12 to $463 \mathrm{~g} / \mathrm{m}^{3}$ of tin (fig. 4). There is no variation in tin content between sample sets from each of the three drainage basins along the Ray River; all surface samples contain tin values, and higher values are erratically dispersed. Lack of anomalous trends or clustering implies no single point source of cassiterite.

Samples from lower No Name Creek were less enriched with tin than samples from Ray River, possibly because of the greater distance to potential source rocks in the Fort Hamlin Hills or possibly due to dilution by sediment from unmineralized areas. Tin content of cutbank samples from lower No Name Creek ranged from 6 to $36 \mathrm{~g} / \mathrm{m}^{3}$.

The heavy-mineral suite in concentrate samples from alluvium of the modern floodplain and from low terraces (Qt) is dominated by ilmenite. Cassiterite is present as black, rounded, sand-size grains. Only a few crystalline and twinned cassiterite grains were found. Concentrates contain 1 to 5 percent monazite and xenotime. Monazite is a least four times more abundant than xenotime, except on upper No Name Creek where this ratio is reversed. Tourmaline, wolframite, zircon, an iron-aluminum spinel, and uranothorite are present in minor to trace quantities. All heavy-mineral concentrates from Ray River and lower No Name Creek contain up to several dozen, minute gold particles. Gold is absent on upper No Name Creek. On lower No Name Creek, gold is spatially associated with the Twg unit.

Upper No Name Creek valley (fig. 5) has a thick loess (Q1) fill, and the creek is slow and meandering. A 9.2-m auger hole drilled in frozen, organic-rich loess did not penetrate gravel or bedrock. Two exposures of bench gravels, which are comparable to the unaccessible buried channels of No Name Creek, were located (fig. 5). One exposure $5 \mathrm{~km}$ east of the highway crossing is a series of channel remnants preserved on a low, resistant bedrock spine that juts perpendicular to and partially across the creek valley. At least three separate channels were sampled at increasing elevations between 9 and $15 \mathrm{~m}$ above the present creek. Tin content in these gravels averaged $1,542 \mathrm{~g} / \mathrm{m}^{3}$ in six samples and ranged up to $3,700 \mathrm{~g} / \mathrm{m}^{3}$ (Barker, 1991).

Additional unexposed channels up to $60 \mathrm{~m}$ above

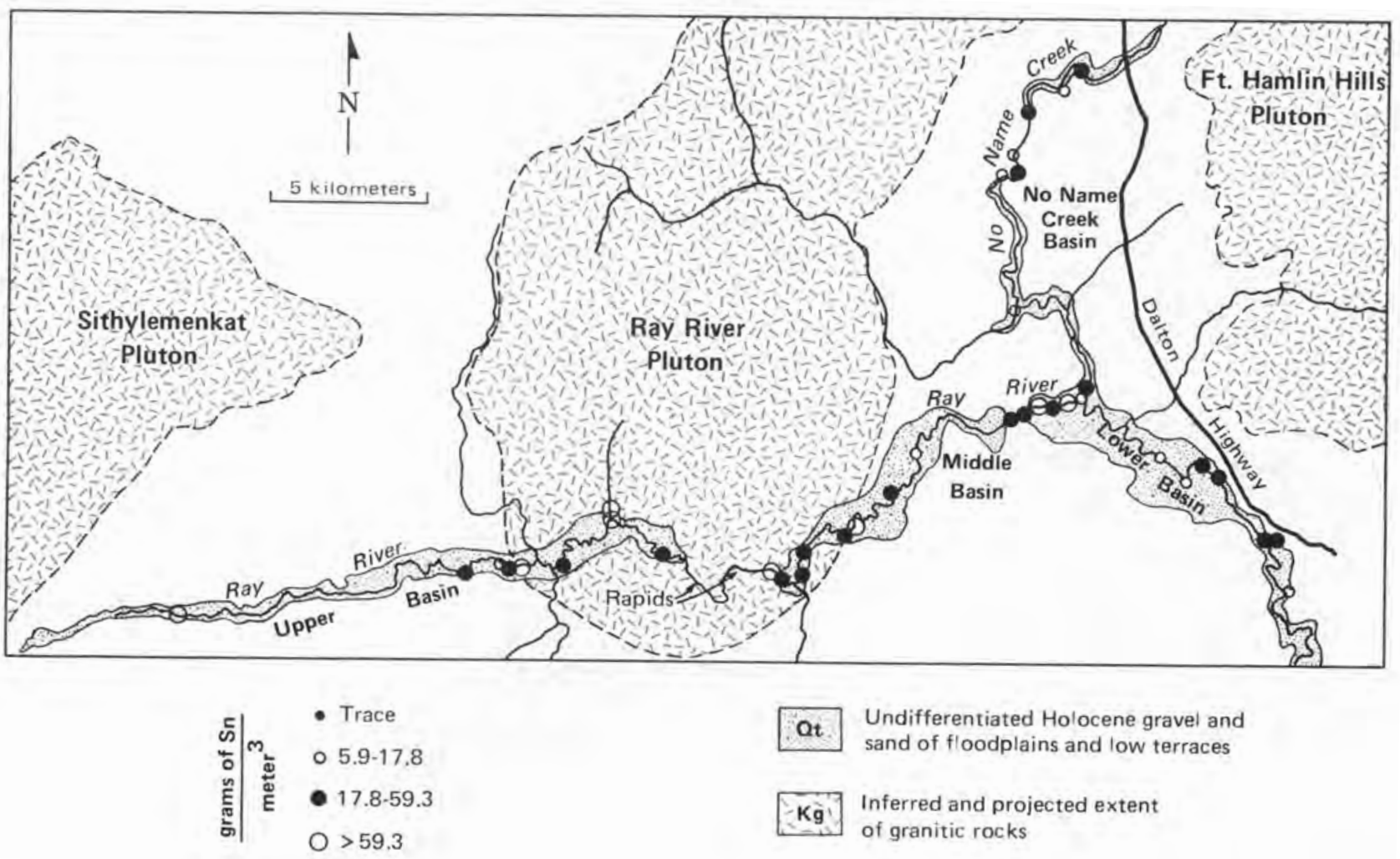

Figure 4. Geologic map of Ray River and No Name Creek drainages showing heavy-mineral sample localities. Location of map area shown in figure 1. 
the present valley floor are indicated in test pits by well-rounded, quartzose, pebble-cobble gravel. These paleochannel deposits contain cassiterite mixed with colluvium and loess. Samples of mixed gravel and colluvium contained trace to $771 \mathrm{~g} / \mathrm{m}^{3}$ of tin. Higher grade samples directly correlate with the abundance of alluvial gravel in the test pits. Gravel clasts are composed of quartz, tourmaline-bearing quartz, granite, chlorite greisen, and hornfels phyllite. Both upstream and downstream from this area, bench deposits have been destroyed by erosion and have been redeposited in modern alluvium.

Upper No Name Creek has apparently been eroding nearby cassiterite-bearing source rocks. At least $60 \mathrm{~m}$ of downcutting has occurred, and sample data indicate that successively younger channels became increasingly rich in cassiterite as gravel was repeatedly reworked.

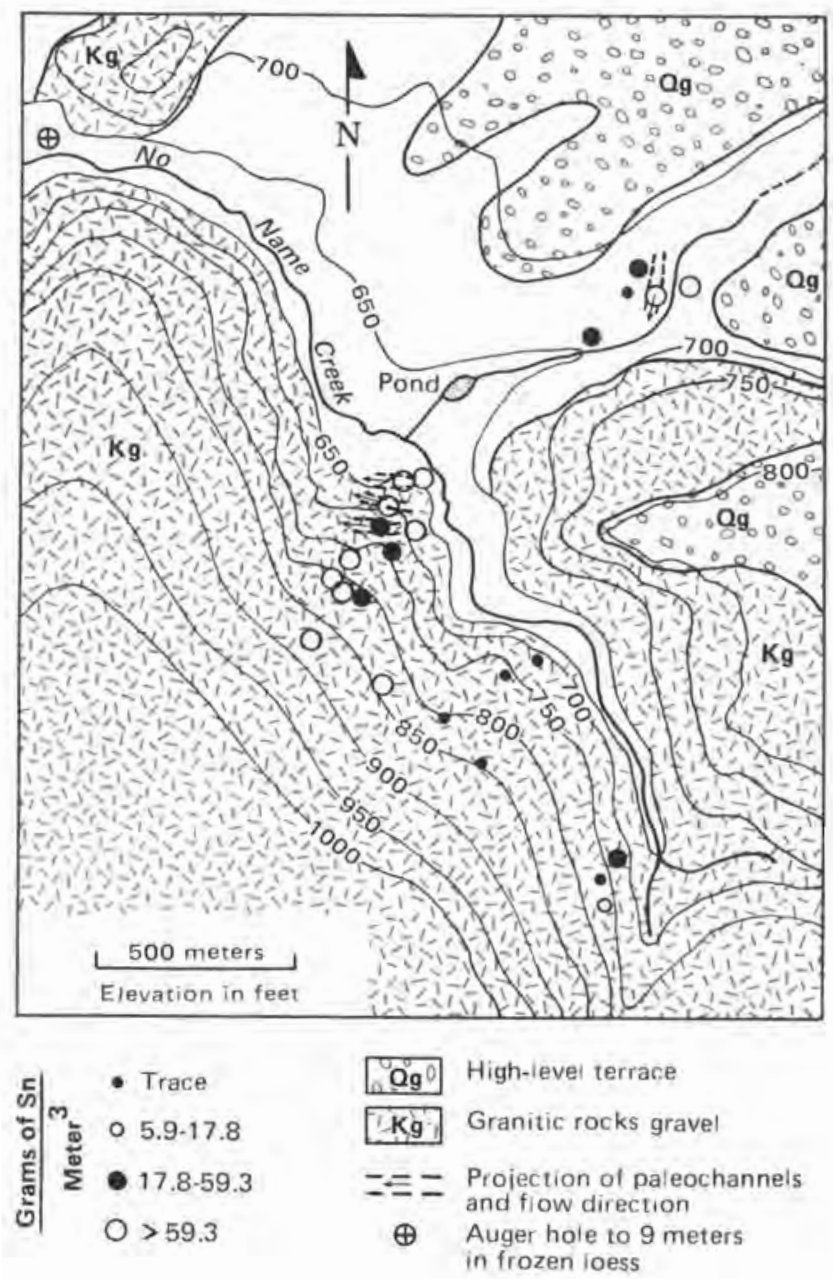

Figure 5. Geologic map of upper No Name Creek showing heavy-mineral sample localities and projections of paleochannels. Location of map area shown in figure 1 .
Located about $0.8 \mathrm{~km}$ northeast of the first exposure, the second site is a gravel-bench remnant on a bedrock escarpment $4.6 \mathrm{~m}$ above a small tributary to No Name Creek. Test pits indicate a paleochannel width of $40 \mathrm{~m}$, and samples contained tin concentrations up to $1,672 \mathrm{~g} /$ $\mathrm{m}^{3}$ in well-rounded gravel of similar composition to the first site.

\section{DISCUSSION}

Tin placers in the Ray River area developed as the result of lengthy and repeated cycles of erosion over large areas of favorable source rock. Modern floodplain and bench gravels are products of the erosion of several Cretaceous granitic plutons, probably in response to tectonic activity that produced graben-like features after mid-Tertiary time. The presence of alkaline fissure basalts, geothermal activity, and stepped elevations of the Tertiary-age coal beds are consistent with an interpreted formation of north- to northeast-striking grabens situated between granitic plutons. Tertiary basalt flows later blocked local drainages from granitic highlands. As a result, 15 to $30 \mathrm{~m}$ of gravelly alluvium were deposited in front of and over the flows. Subsequent downcutting of the flows and erosion coupled with fluvial and colluvial processes reworked most high-level gravels. The abundance of cassiterite and other heavy minerals correlates with the degree of fluvial reworking.

Data infer that a significant resource of tin and byproduct rare earth elements exists in the Ray River watershed (Barker, 1991), where estimated tin resources of between 28 and 78 million kgs are projected. However, these estimates are subject to a wide margin of error. Most of the tin resources in the Ray River valley are at grades of 59 to $296 \mathrm{~g} / \mathrm{m} 3$, which is probably not economic for a mineral deposit in Alaska at this time. However, elsewhere in the world tin dredges commonly work ground containing 178 to $237 \mathrm{~g} / \mathrm{m} 3$. Although conditions are different from Alaska, Malaysian tin dredges have successfully operated in ground containing as little as 107 g/m3 (Sager, written commun., 1990).

\section{ACKNOWLEDGMENTS}

Field mapping was assisted by J. Dean Warner, formerly with the U.S. Bureau of Mines, and by Roger E. Burleigh and Jeff Y. Foley (USBM). Manuscript review was provided by Thomas K. Bundtzen (DGGS) and Steve R. Morrison (Yukon North Affairs Program). Ellen E. Harris (DGGS) prepared the final illustrations in this paper. 


\section{REFERENCES}

Albanese, M.D., 1987, A basalt flow in the Fort Hamlin Hills, Bettles A-1 Quadrangle: Alaska Division of Geological and Geophysical Surveys Public-data File $87-25,8$ p.

Arth, J.G., Zmuda, C.C., Foley, N.K., Criss, R.E., Patton, W.W., and Miller, T.P., 1989, Isotopic and trace element variations in the Ruby batholith, Alaska, and the nature of the deep crust beneath the Ruby and Angayucham terranes: Journal of Geophysical Research, v. 94, no. B11, p. 15,941-15,955.

Barker, J.C., 1981, Coal and uranium investigation of the Yukon Flats Cenozic basin: U.S. Bureau of Mines Open-file Report 140-81, 63 p.

1983, Reconnaissance of tin and tungsten in heavy-mineral panned concentrates along the
trans-Alaska pipeline corridor north of Livengood, interior Alaska: U.S. Bureau of Mines Open-file Report 59-83, 24 p.

1991, Investigation of tin-rare earth placers in the Ray River watershed: U.S. Bureau of Mines Open-file Report 34-91, 48 p.

Barker, J.C., and Foley, J.Y., 1986, Tin reconnaissance of the Kanuti and Hodzana Rivers uplands, central Alaska: U.S. Bureau of Mines Information Circular 9104, $27 \mathrm{p}$.

Herreid, Gordon, 1969, Geology and geochemistry, Sithylemenkat Lake area, Bettles Quadrangle, Alaska: Alaska Division of Mines and Geology Geologic Report 35, 22 p. 


\title{
GEOLOGY AND GEOCHEMISTRY OF THE GAGARYAH BARITE DEPOSIT, WESTERN ALASKA RANGE, ALASKA
}

\author{
By \\ Thomas K. Bundtzen ${ }^{1}$ and Wyatt G. Gilbert ${ }^{1}$
}

\section{INTRODUCTION}

In 1989, while conducting 1:63,360-scale geologic mapping on State-interest lands near the headwaters of Gagaryah River in the Lime Hills D-4 Quadrangle of western Alaska (Gilbert and others, 1990), barite-bearing sedimentary rocks of presumed Frasnian (early Late Devonian) age were discovered by DGGS geologists. The discovery-herein named the Gagaryah barite deposit-consists of nodular, laminated, composite and massive, light-gray or white barite in a section up to $51 \mathrm{~m}$ thick in sublithic siltstone and shale in the Devonian to Jurassic Mystic terrane (Jones and others, 1982; Gilbert and Bundtzen, 1984; Reed and Nelson, 1980). This paper describes the geology and geochemistry of the barite mineralization, provides size and grade estimates, and compares the Gagaryah deposit with other stratiform barite deposits in Alaska and the North American Cordillera.

\section{REGIONAL GEOLOGY}

Layered bedrock units in the study area (fig. 1) belong to the Dillinger and Mystic terranes of Cambrian through Jurassic (Jones and others, 1982; Bundtzen and Gilbert, 1983; Gilbert and Bundtzen, 1984). The Dillinger terrane in the study area consists of Cambro-Ordovician limestone turbidite(OCls), Early Ordovician to late Early Silurian graptolitic shale, chert, and siltstone (SOsh), Middle to Late Silurian micaceous sandstone turbidite and minor graptolitic limestone (mSs), Late Silurian to Early Devonian massive-to-laminated limestone and calcareous sandstone (DSl), and Late Silurian to Early Devonian limestone conglomerate, and siltstone (DS1s). Fossil evidence for dating for these units was reported by Bundtzen and others (1988) and Gilbert and others (1989) from equivalent units in the McGrath Quadrangle.

The Mystic terrane in the study area consists of Devonian to upper Paleozoic carbonaceous shale and plantbearing, sublithic sandstone (Ds); black-to-variegated chert (Dcs); and fossiliferous limestone (uPzs) that are exposed in a northeast-trending structural trough in the central part of the map area. Two fossil localities in the shale-silty sandstone unit (Ds) contain brachiopod-rich

\footnotetext{
${ }^{1}$ Alaska Division of Geological and Geophysical Surveys, 794 University Avenue, Suite 200, Fairbanks, Alaska 99709-3645.
}

faunas of probable Frasnian age. Late Paleozoic radiolaria and megafauna are reported from the overlying uPzs unit (Gilbert and others, 1990). Rock units believed to be equivalent to units Ds, Dcs, and uPzs unconformably overlie the Dillinger Terrane in the McGrath A-2 and B-2 Quadrangles $40 \mathrm{~km}$ northeast of the study area. Gilbert and Bundtzen (1984) and Bundtzen and Gilbert (1983) correlated these rocks with the Mystic terrane as mapped by Reed and Nelson (1980) in the Talkeetna Quadrangle.

Ultramafic to felsic dikes of early(?) Tertiary age intrude older layered rock units with no preferred structural orientation (fig. 1). Alluvial, colluvial, and glacial deposits (Qat, Qc, and Qd) overlie all older bedrock units, mainly as valley-fill accumulations.

The Cambrian to Early Devonian Dillinger terrane is thrust over the early Late Devonian to Permian(?) Mystic sequence along the Gagaryah thrust fault (fig. 1), probably a response to a middle Cretaceous compressional event described by Bundtzen and Gilbert (1983). Tertiary and younger high-angle faults, one of which forms a northeast-striking Holocene(?) escarpment, vertically offset bedrock units a few tens of meters throughout the study area in the Lime Hills D-4 Quadrangle.

\section{GEOLOGY OF GAGARYAH BARITE DEPOSIT}

A geologic sketch map and a stratigraphic section of the Gagaryah deposit are shown in figures 2 and 3, respectively. Barite crops out sporadically at elevations ranging from 2,600 to 2,850 ft (793 to $869 \mathrm{~m}$ ) over a minimum strike length of $640 \mathrm{~m}$ and is fairly well exposed in three northwest-striking gullies that cross northeaststriking Devonian strata. The best exposures form a nearly continuous 100-m-thick section in the discovery area immediately north of a Quaternary landslide (fig. 2). The deposit is buried at both ends beneath colluvium and was not found in an equivalent section across a stream valley approximately $1,500 \mathrm{~m}$ northeast of the mapped area (fig. 2).

The lower $30 \mathrm{~m}$ of the sedimentary section illustrated in figure 3 consists of alternating layers of dark-gray, limonite-stained cherty argillite (15 percent) and darkgray-to-black, sooty, carbonaceous shale and brown siltstone (85 percent). Incompetent shales are conspicuously isoclinally folded with fold axes trending N. $40^{\circ} \mathrm{W}$. and 


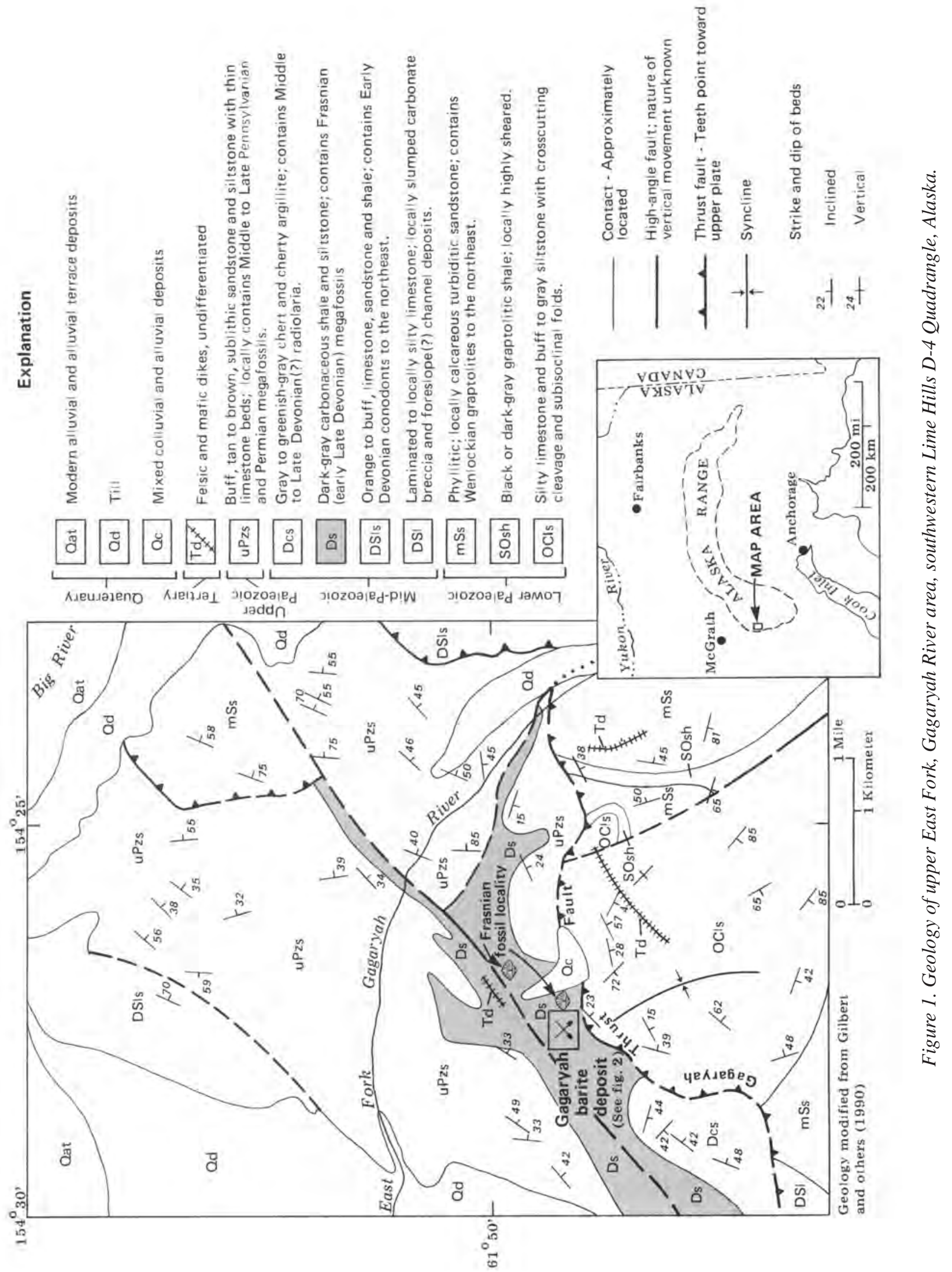




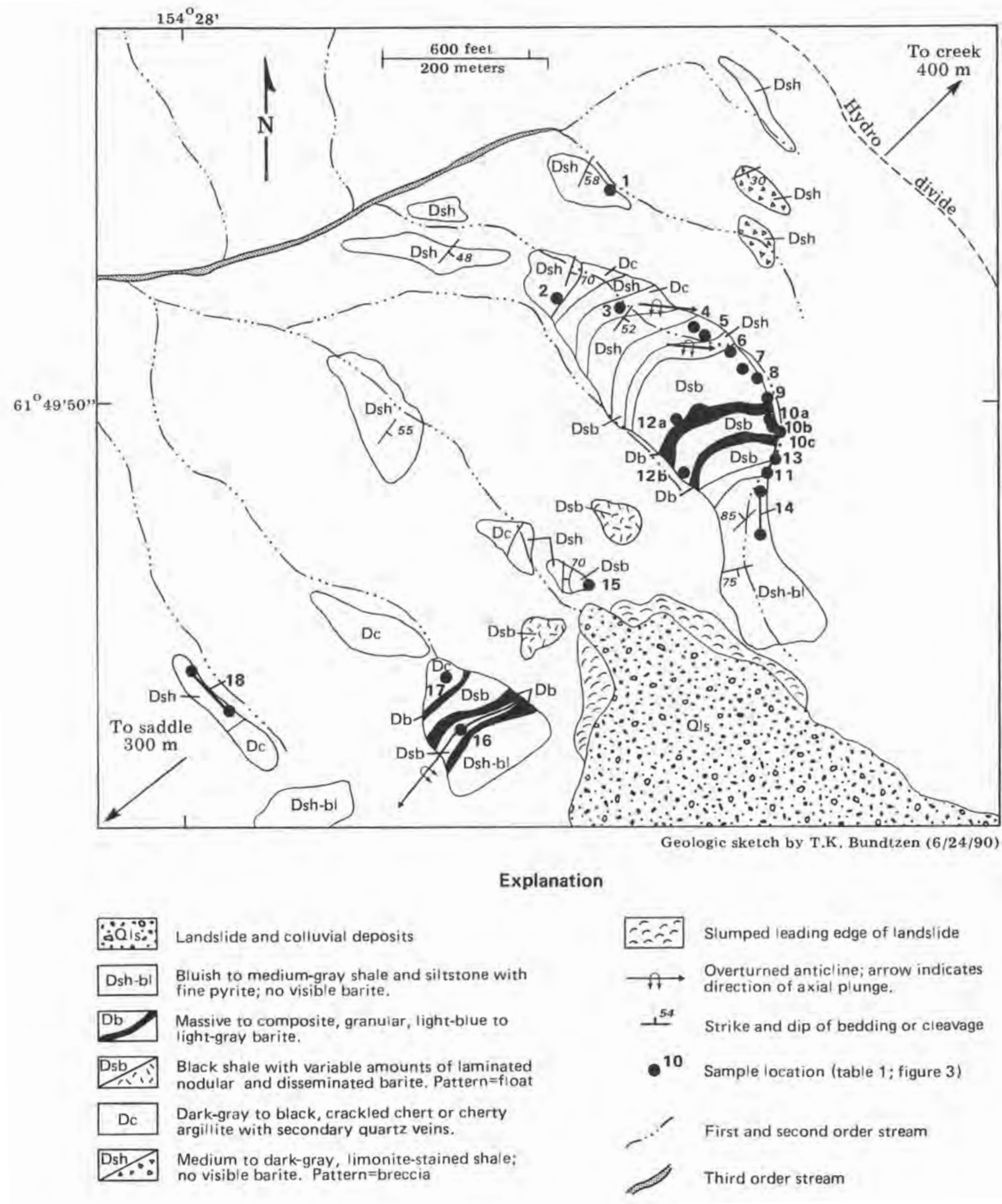

Figure 2. Gagaryah barite prospect, southwestern Lime Hills D-4 Quadrangle, Alaska. 


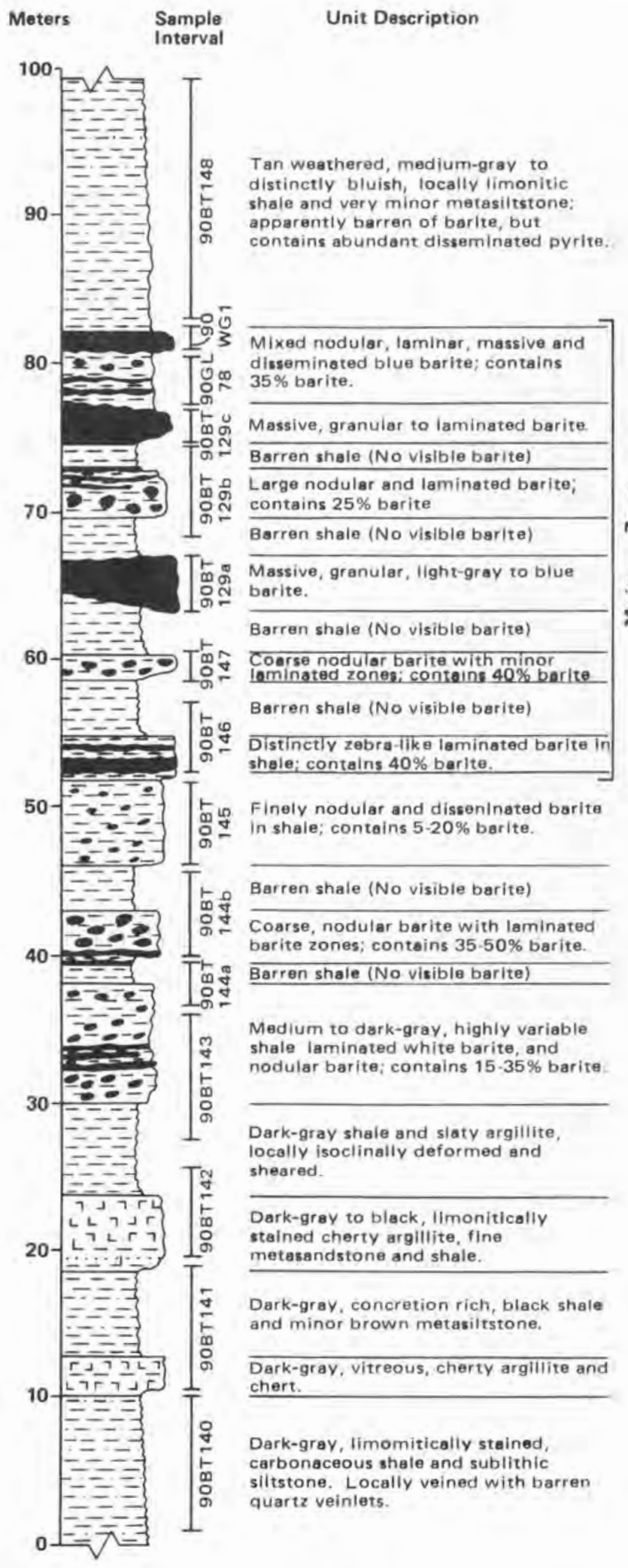

plunging $20^{\circ}$ to $40^{\circ}$. Visible barite is present in $39 \mathrm{~m}$ of a 51-m-thick section exposed in the discovery gully (fig. 3); this is the maximum thickness observed for the Gagaryah deposit. Two other gully exposures farther southwest contain respectively, 7- and 6-m-thick zones of mainly massive barite, which indicates that the deposit thins markedly in that direction.

Barite at the Gagaryah deposit is present in a variety of morphological forms, several of which are summarized below. The main zone consists of alternating zones of nodular, laminated, composite and massive, light-grayto-light-bluish-gray barite (figs. 3, 4 and 5). Some shale horizons contain minor disseminated pyrite, but otherwise the deposit is free of sulfides.

Nodular barite has several forms: (1) fine-grained aggregates, (2) fiber-bundle nodules, and (3) spherulites. Fine-grained aggregates are irregular to elliptical in shape and have crystalline structure similar to massive barite (fig. 4). Fiber-bundle needles and barite spherulites are typically associated with fine-grained aggregates and are composed of rosettes of euhedral, dipyramidal barite grains 1 to $5 \mathrm{~mm}$ long (fig. 6). Cores of some fiber bundles contain organic(?) carbon or spherical radiolaria(?).

Laminated barite consists of fine-grained aggregates and very fine-grained fiber bundles of barite crystals that are interconnected in a shale-siltstone matrix. Thin laminae of barite are frequently interlayered with folded, carbon-rich detritus and quartz grains. Some barite intrudes into the underlying sedimentary rock (fig. 7).

Composite barite consists of approximately 50 percent (by volume) barite grains 0.5 to $3 \mathrm{~mm}$ long in a matrix of organic carbon, white mica, and quartz-rich silt. Barite grains are distinctly elongated parallel to sedimentary layering. In thin section, they impart a texture superficially resembling trachyte (fig. 8).

Massive barite consists of light-gray-to-distinctly bluish, mostly very fine-grained, locally medium-grained, randomly oriented, dipyramidal barite crystals with very minor quartz and silt impurities. Massive barite in the Gagaryah deposit resembles micritic limestone elsewhere in the section and is chiefly distinguished by its anomalously high specific gravity.

Shales and siltstones above barite horizons (fig. 2) resemble similar units below the barite but differ by having a distinctive bluish or blue-gray, sooty alteration, and a lack of chert.

Figure 3. Stratigraphic section showing barite-bearing sedimentary rock, Gagaryah barite deposit. Measured and sampled by T.K. Bundtzen, June 24, 1990, from outcrop in stream ravine dissecting main deposit. Barite content estimated visually. 


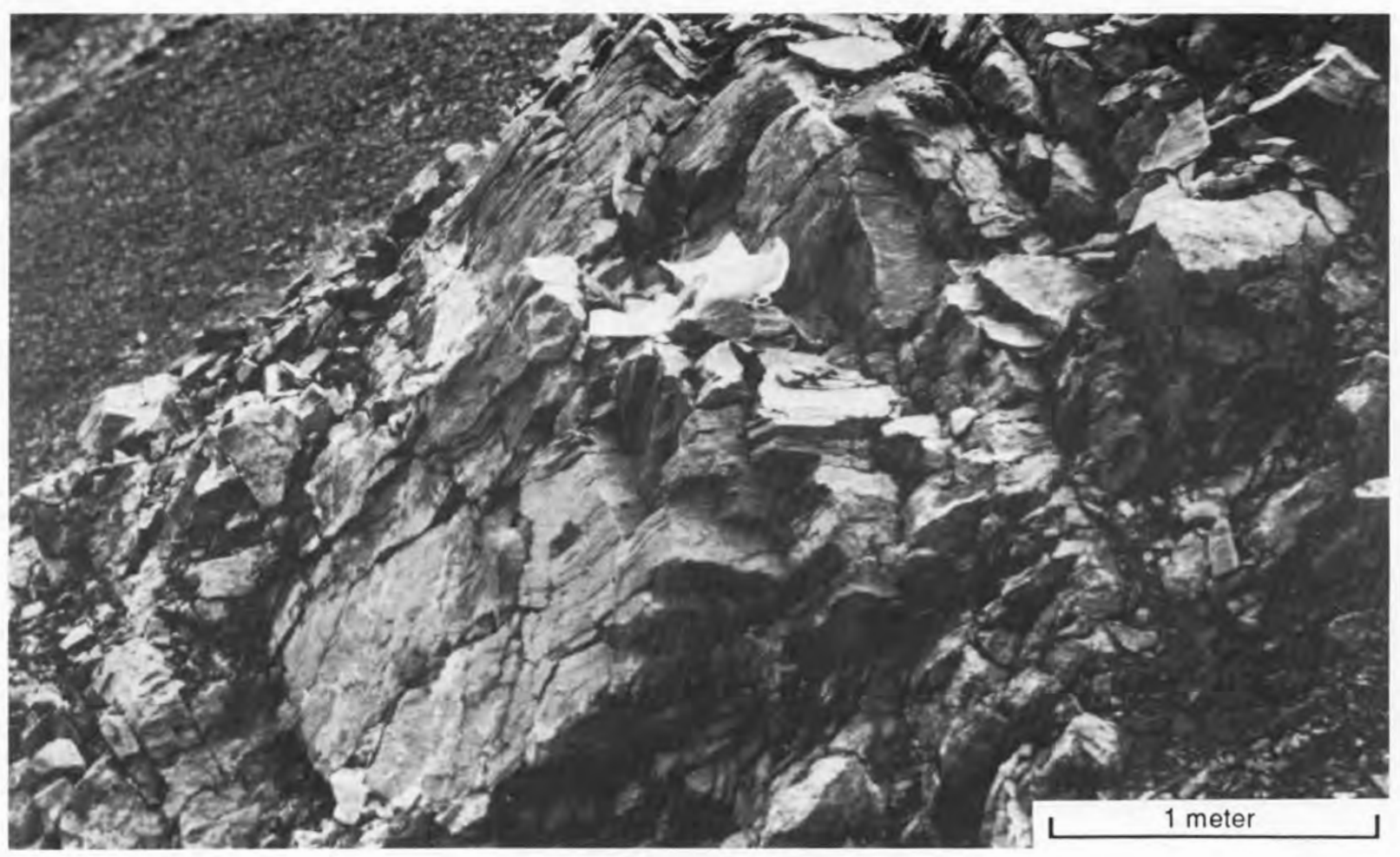

Figure 4. Massive barite in discovery gully.

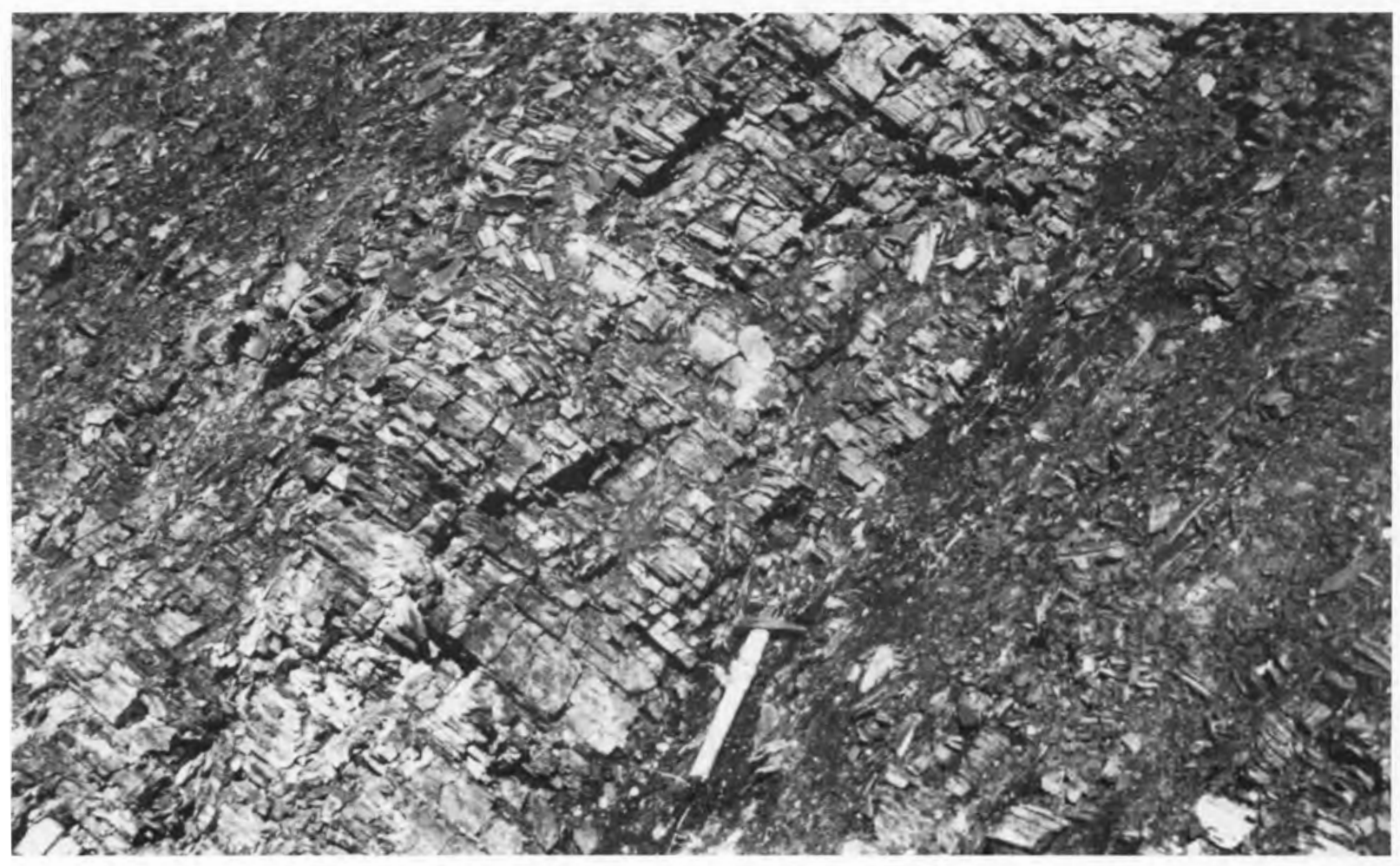

Figure 5. Laminated and nodular barite section, discovery gully. Hammer provides scale. 


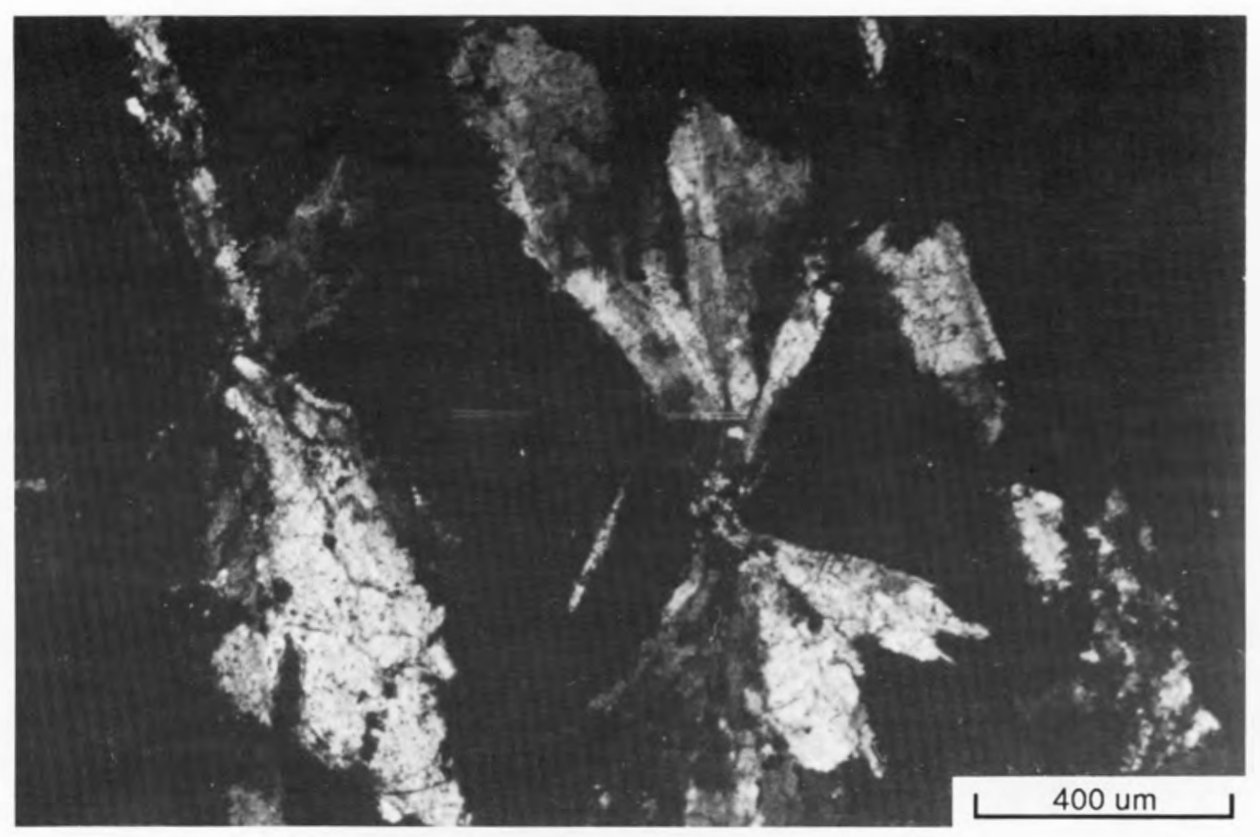

Figure 6. Photomicrograph of fiber bundles of euhedral barite crystals under crossed nicols, Gagaryah deposit, Alaska.

Two brachiopod-rich fossil localities 50 to $60 \mathrm{~m}$ stratigraphically above the barite mineralization are Frasnian (Gilbert and others, 1990). Possible equivalent units in the McGrath B-2 Quadrangle contain both Givetian (Middle Devonian) megafossils and Frasnian conodonts; all ages support a Middle to early Late Devonian age for the Gagaryah deposit.

\section{GEOCHEMISTRY OF GAGARYAH DEPOSIT}

Fifteen chip-channel and composite-grab samples of barite mineralization and barren shale and chert were collected in the vicinity of the deposit to determine its major-, minor-, and trace-element contents (table 1). Geochemical results indicate that the Gagaryah deposit is deficient in alumina, base metals, strontium, and phosphorous, only slightly enriched in silver and bismuth, and contains no significant values of lead, zinc, or copper. Essentially only barium mineralization is present in the prospect. Strontium content ranges from 119 to 453 ppm and averages 264 ppm (0.026 percent). Although barite $\left(\mathrm{BaSO}_{4}\right)$ forms a complete solid-solution series with celestite $\left(\mathrm{SrSO}_{4}\right)$, the barium end member is heavily represented in the Gagaryah deposit.

Clastic and chemical sediments above and below the main barite horizon have contrasting geochemical signatures. Overlying shales apparently have greater trace amounts of chromium, nickel, strontium, and vanadium than similar units below the barite. Mudstone in both sections contains near-equal trace-element levels of molybdenum (15 ppm), phosphorous (84 ppm), and iron (1.18 percent). Strata above and below the barite and the mineralization are deficient in alumina (shales $=0.88$ percent $\mathrm{Al}$; mineralization $=0.21$ percent $\mathrm{Al}$ ). These results indicate that host lithologies were probably not pelitic sediments, which typically average 15.6 percent $\mathrm{Al}_{2} \mathrm{O}_{3}$ in continental margin environment (Krauskopf, 1969).

No total-carbon analyses are available; however, equivalent units in the McGrath Quadrangle yield values ranging from 1.4 to 3.5 percent total carbon, indicating that Devonian sediments in the Mystic terrane are carbon enriched.

Chip samples were systematically collected from channels in $39 \mathrm{~m}$ of the 51-m-thick barite zone in the discovery gully. Other channel samples were collected along strike. Barium values range from 26.06 to 56.92 percent (40 to 88 percent barite) and average 37.4 percent barium (58 percent barite) over the $39-\mathrm{m}$ sample interval (fig. 3; table 1).

Five samples of massive barite range from 47.4 to 56.9 percent barium ( 73 to 88 percent barite) and average 53.3 percent barium (82 percent barite). A 3-kg sample 


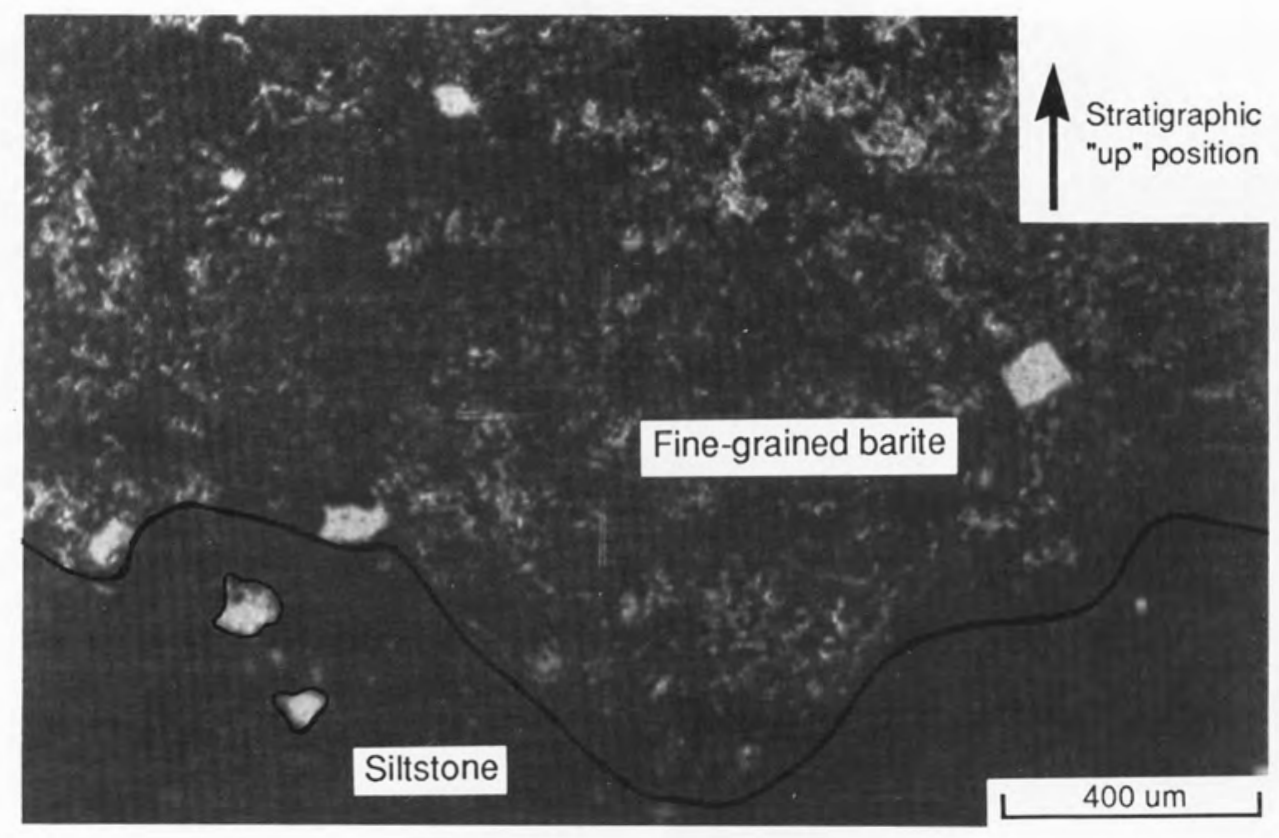

Figure 7. Photomicrograph of fine-grained barite layer in contact with carbonaceous siltstone, Gargaryah deposit. Note load casts in plain light.

at locality 10a (fig. 2) had a specific gravity of 4.24 , indicating that massive barite lenses are acceptable for heavy-media well-drilling applications (Bundtzen and Henning, 1978); however, lower grade nodular- and laminated barite types, which predominate at the deposit, will probably require beneficiation for this application. Sulfur-isotope analyses of nodular and massive barite from the Gagaryah deposit yield $\mathrm{S}^{34}$ values of +20 and +24 , respectively.

The volume of the Gagaryah deposit was estimated using our systematic surface sampling and the fence-line and half-square reserve models of Patterson (1959), Krige and Ueckermann (1963), and McKinstry (1948). We assume that the Gagaryah deposit is a narrow, trough-like body with a strike length of $640 \mathrm{~m}$; thicknesses of $59 \mathrm{~m}, 7$ $\mathrm{m}$, and $6 \mathrm{~m}$, determined at three localities along strike; and a downdip rate equal to about half of the surface strike at those three localities. Hence, inferred reserves probably amount to at least 1.08 million $\mathrm{m}^{3}$, or 2.3 million tonnes, of barite mineralization with an overall average grade of 37.4 percent barium or 57.0 percent barite. About 20 percent of the total, or 460,000 tonnes, is inferred to be massive barite lenses averaging 53 percent barium (81 percent barite). The remaining 1.84 million tonnes are inferred to consist of nodular, laminated, and composite mineralization averaging 33.5 percent barium ( 51 percent barite). These inferred reserves fall in the 130,000 - to 30-million-tonne range commonly estimated for the bedded-barite model of Cox and Singer (1986).

\section{DEPOSIT CLASSIFICATION AND COMPARISONS WITH OTHER NORTH AMERICAN EXAMPLES}

Stratiform barite deposits are thought to form by several syngenetic or diagenetic processes that include: (1) proximal deposition near a high-temperature hydrothermal vent; (2) distal barite precipitation from a vent along a redox interface; and (3) low-temperature and diagenetic barite formation related to oxygenation of a reduced, anoxic water mass (Poole, 1988; Lydon and others, 1985).

Field, isotopic, and petrographic evidence summarized here indicates that the Gagaryah deposit is probably formed syngenetically with barite rapidly precipitating in the water column from low-temperature hydrothermal fluids distal to exhalative vents (Lydon and others, 1985). The sulfur-isotope data compare closely with that estimated for Late Devonian seawater (Claypool and others, 1980). The absence of base metals precludes an association with proximal vent systems usually associated with volcanogenic massive-sulfide systems. Barite rosettes and nodules show no evidence of fabric expansion (fig. 6). Many finely laminated barite layers bear evidence of synsedimentary deformation, including load casting and slumping (fig. 7).

Table 2 compares the Gagaryah deposit with selected stratiform deposits in the North American Cordillera. The 


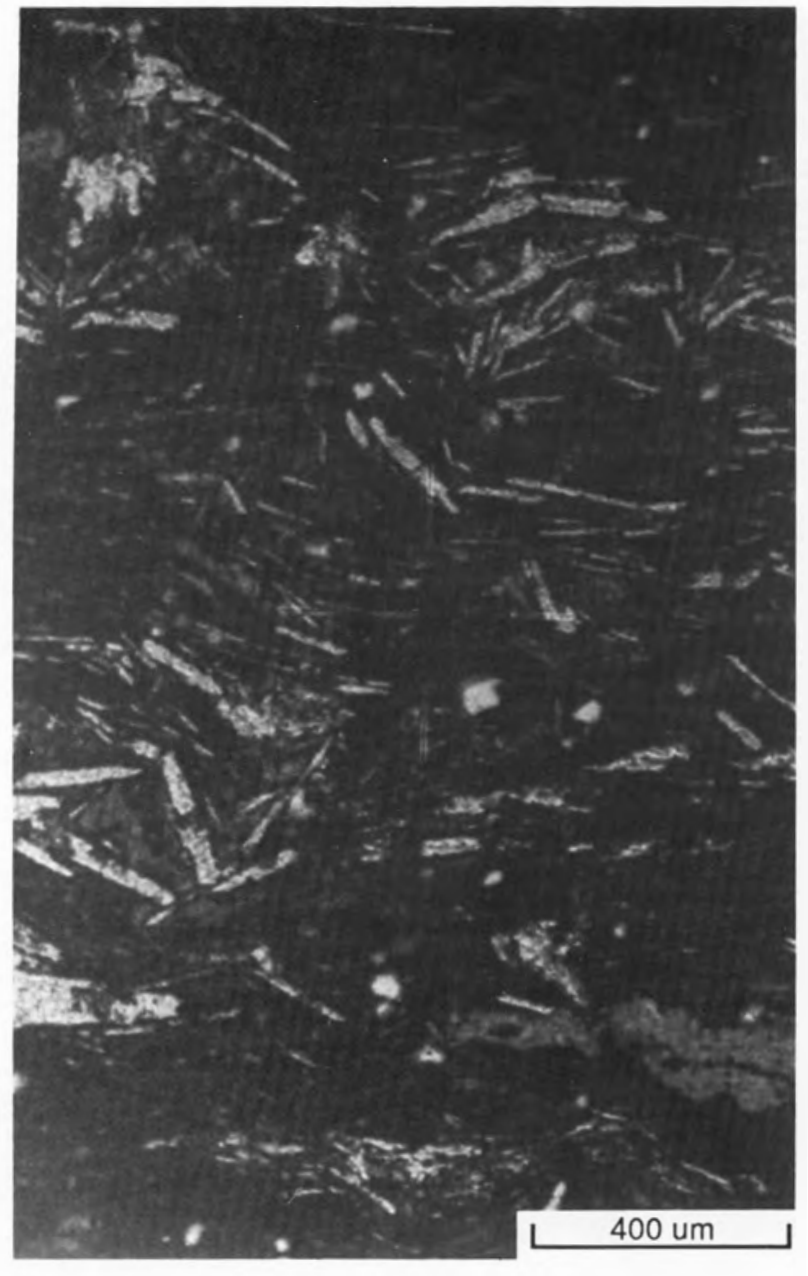

Figure 8. Photomicrograph of composite barite showing elongated barite grains subparallel to bedding, Gagaryah deposit, crossed nicols.

Gagaryah deposit is similar in age and morphology to the East Northumberland Canyon deposits in Nevada (Graber and Chafetz, 1990) and the Atigun Canyon deposits in the central Brooks Range (Paris, 1977), but it lacks the phosphate and chert paragenesis associated with these primary bedded barite deposits, which are thought to be syngenetically formed from low-temperature brine seeps.

Barite deposits at Glacier Creek, Castle Islands, and Lime Point in southeastern Alaska (Hawley, 1976; Nokleberg and others, 1987; Herreid and others, 1978) and the Red Dog and Nimutuk properties in the western Brooks Range (Lange and others, 1985; Moore and others, 1986; Mayfield and others, 1979) clearly contrast with the
Gagaryah deposit because of their significant base-metal and silver values and volcanic-exhalative associations.

Although clearly lacking in base metals, the Gagaryah deposit compares most favorably with the Middle to Late Devonian barite-sulfide and barite-only "sedex" deposits in northeastern British Columbia and in the Selwyn Basin of central Yukon. Those deposits are primarily in the Earn Group, a Devono-Mississippian assemblage of carbonaceous and siliclastic marine strata that probably represents an episode of rifting or wrench faulting, or both, that interrupted passive-margin sedimentation in the outer parts of the Cordilleran miogeocline (Gordey and others, 1982). Barren barite deposits are widespread in the Earn Group but are best studied at MacMillan Pass in central Yukon. There, in the MacMillan Fold Belt, an unusual concentration of 15 barite deposits-including the Walt, Hess, Tryala and North Gary deposits-compares closely in morphology, age, and stratigraphic position with the Gagaryah deposit (table 2). Barite deposits in the MacMillan Pass area are peripheral to and both predate and postdate the nearby Tom and Jason exhalative zinc-lead-silver deposits (Abbott and Turner, 1990). We note similarities between the stratigraphic section at the Gagaryah deposit (fig. 2) and that part of the Earn Group which hosts most barite deposits in the MacMillan Pass area.

We have speculated in past years that the Dillinger and Mystic terranes in the western Alaska Range represent fragments of Paleozoic continental margins right-laterally offset by the Tintina and related transcurrent faults from stratigraphically equivalent units in Selwyn Basin of Yukon Territory. The Earn Group may be equivalent to parts of the lower Mystic terrane in the western Alaska Range; similarities of barite mineralization in both areas strengthen this correlation. Canadian models for MacMillan Pass stratiform-barite \pm sulfide deposits (Abbot and Turner, 1990) imply that separate sulfide-rich deposits could exist within a few kilometers of barren barite deposits like the Gagaryah deposit.

\section{ACKNOWLEDGMENTS}

We thank J. Grant Abbott (Yukon Northern Affairs Program) and Milton A. Wiltse (DGGS) for reviewing the manuscript. Gregory M. Laird and Jeffrey T. Kline ably assisted the authors at the prospect during the 1989 and 1990 seasons. 
Table 1. Analytical results of bedrock samples from Gagaryah barite deposit, Lime Hills D-4 Quadrangle, western Alaska, keyed to figure 2

\begin{tabular}{|c|c|c|c|c|c|c|c|c|c|c|c|c|c|c|c|c|c|c|c|c|c|c|c|}
\hline \multirow[b]{2}{*}{$\begin{array}{l}\text { Map } \\
\text { no. }\end{array}$} & \multirow[b]{2}{*}{$\begin{array}{c}\begin{array}{c}\text { Field } \\
\text { no. }\end{array} \\
\end{array}$} & \multirow[b]{2}{*}{$\begin{array}{l}\mathrm{Ba} \\
(\%)\end{array}$} & \multirow[b]{2}{*}{ Ag } & \multirow[b]{2}{*}{$\begin{array}{l}\mathrm{Hg} \\
(\mathrm{ppb})\end{array}$} & \multirow[b]{2}{*}{$\underline{\mathrm{Cu}}$} & \multirow[b]{2}{*}{$\underline{\mathrm{Pb}}$} & \multirow[b]{2}{*}{$\underline{\mathrm{Zn}}$} & \multirow[b]{2}{*}{ oㅡ } & \multirow[b]{2}{*}{ As } & \multirow[b]{2}{*}{$\underline{\text { Co }}$} & \multicolumn{7}{|l|}{$\mathrm{ppm}$} & \multicolumn{5}{|c|}{$(\mathrm{ppm})$} & \multirow[b]{2}{*}{ Description of samples } \\
\hline & & & & & & & & & & & $\underline{\mathrm{Cr}}$ & $\underline{\mathrm{N}} \mathrm{i}$ & $\underline{B i}$ & $\underline{P}$ & $\underline{\mathrm{S}} \underline{\mathrm{r}}$ & $\underline{\mathrm{Na}}$ & $\underline{\mathrm{U}}$ & $\begin{array}{l}\mathrm{K} \\
(\%)\end{array}$ & $\begin{array}{ll}\mathrm{V} \\
(\mathrm{ppm})\end{array}$ & $\begin{array}{l}\mathrm{Mg} \\
(\%)\end{array}$ & $\begin{array}{l}\mathrm{Fe} \\
(\%) \\
(\%)\end{array}$ & $\begin{array}{l}\mathrm{Al} \\
(\%)\end{array}$ & \\
\hline 1 & $90 \mathrm{BT} 140$ & 0.05 & 0.02 & ND & 15 & 10 & 11 & 14 & 15 & 2 & 24 & 13 & ND & ND & 5 & ND & ND & 0.24 & 30 & 0.08 & 0.95 & 0.55 & Grab sample dark-gray limonitic shale and carbonaceous siltstone \\
\hline 2 & $90 \mathrm{BT} 141$ & 0.22 & 2.0 & 11 & 18 & 20 & 38 & $\underline{9}$ & 10 & & 62 & 2 & 4 & 130 & 17 & 200 & 30 & 0.90 & 161 & 0.09 & 1.24 & 1.09 & Concretion-rich black shale; chip channel over $5 \mathrm{~m}$ of section \\
\hline 3 & $90 \mathrm{BT} 142$ & 0.65 & 1.9 & $\frac{11}{7}$ & 25 & 4 & 13 & 16 & ND & ND & 40 & 13 & 5 & 100 & 20 & 200 & 20 & 0.27 & 48 & 0.10 & 0.82 & 0.80 & $\begin{array}{l}\text { Chip phannel of } 10 \mathrm{~m} \text { thickness of limonite and brecciated shale and cherty } \\
\text { argillite }\end{array}$ \\
\hline 4 & 90BT143 & 26.06 & 2.2 & 10 & 18 & 10 & ND & 11 & 30 & 2 & 55 & 4 & 12 & 470 & 198 & 200 & 10 & 0.18 & 37 & 0.02 & 3.85 & 0.30 & 8-m-thick chip channel of nodular barite-shale zone \\
\hline 5 & . & 32.82 & 2.8 & $\frac{10}{7}$ & 12 & ND & & $\frac{\pi}{2}$ & 5 & & 30 & 18 & 12 & 120 & & 200 & 20 & 0.19 & 48 & $0 .(\mathrm{r}$ & 0.69 & 0.27 & 4-m-thick chip channel sample of laminated to nodular barite-rich shale \\
\hline 6 & $90 \mathrm{BT} 144 \mathrm{~b}$ & 29.81 & 2.4 & $\bar{z}$ & 9 & 10 & 30 & 5 & ND & 4 & 26 & 14 & 10 & 100 & 218 & 200 & 20 & 0.23 & 66 & 0.02 & 0.48 & 0.28 & $\begin{array}{l}\text { 2-m-thick chip channel sample of rhythmically bedded barite with minor } \\
\text { white barite crvstals }\end{array}$ \\
\hline 7 & $90 \mathrm{BT} 145$ & 27.89 & 2.4 & 7 & 13 & ND & 30 & 4 & 5 & 4 & 30 & 9 & 14 & 70 & 253 & 200 & 20 & 0.55 & 87 & 0.06 & 0.77 & 0.71 & $\begin{array}{l}\text { 6-m-thick chip channel of white to gray disseminated to nodular barite in } \\
\text { black shale }\end{array}$ \\
\hline 8 & $90 \mathrm{BT} 146$ & 42.24 & 2.4 & 7 & 5 & 10 & 40 & ND & 5 & 6 & 9 & 19 & 14 & 150 & 453 & 200 & ND & 0.09 & 52 & 0.64 & 0.29 & 0.14 & $\begin{array}{l}\text { 2.5-m-thick chip channel of massive to locally laminated barite bed; } \\
\text { contains } 50 \text { percent barite }\end{array}$ \\
\hline 9 & $90 \mathrm{BT} 147$ & 38.57 & 1.6 & 14 & 5 & ND & 30 & 4 & 5 & 4 & 18 & 15 & 20 & 70 & 302 & 200 & 20 & 0.25 & 78 & 0.05 & 0.30 & 0.31 & $\begin{array}{l}\text { 2-m-thick zone of coarse nodular barite in black shale; immediately below } \\
\text { massive barite }\end{array}$ \\
\hline 10a & 9 & 54.12 & 2.2 & 11 & 2 & 10 & 30 & ND & 5 & 3 & 7 & 4 & 12 & & & 1100 & & & & 0.07 & 0.15 & 0.06 & gray, massive, fine-grained barite bed about $3.5 \mathrm{~m}$ thick \\
\hline $10 \mathrm{~b}$ & $90 \mathrm{BT} 12$ & 26.48 & 2. & & 2 & 1 & & & 5 & 3 & 10 & & 16 & & & & & & & & & & 15 \\
\hline $10 \mathrm{c}$ & $90 \mathrm{BT} 129 \mathrm{c}$ & 48.16 & 2. & $\frac{1}{2}$ & 1 & $\mathrm{NI}$ & 1 & $\mathrm{NL}$ & 5 & 4 & & & & & & & & & 8 & & 4 & & out $2 \mathrm{~m}$ thick \\
\hline 11 & 90 & 56.92 & 2. & $\mathrm{ND}$ & ND & 10 & 16 & 1 & ND & 4 & 1 & 9 & 2 & & & & & & & 0.09 & & 0.01 & $x_{-1}$ \\
\hline $12 a$ & $89 \mathrm{WG} 9$ & 53.98 & ND & 20 & 2 & 2 & $<$ & 7 & 1 & 10 & 22 & $<50$ & $\mathrm{~N}$ & & & & & & ND & $\mathrm{A}$ & $<0.50$ & & ample; \\
\hline $12 \mathrm{~b}$ & 89WG96b & 53.95 & ND & 10 & 4 & 2 & $<200$ & 10 & 1 & ic & 15 & $<50$ & $N$ & & & & & & & & $<0.50$ & & sample, mass \\
\hline 13 & 90GL78 & 28.78 & 2.4 & ND & 3 & $\mathrm{ND}$ & 10 & ND & ND & 5 & 98 & 10 & 10 & 30 & 298 & 10 & $\mathrm{~N}$ & ND & 10 & 0.51 & 0.28 & 0.07 & $\begin{array}{l}\text { Chip channel sample of nodular barite horizon about } 3 \mathrm{~m} \text { above upper } \\
\text { massive barite lense }\end{array}$ \\
\hline 14 & $90 \mathrm{BT} 148$ & 1.43 & 2.0 & ND & 3 & 10 & ND & 2 & ND & 3 & 48 & 12 & 16 & 40 & 85 & 300 & ND & 0.87 & 106 & 0.09 & 0.43 & 0.99 & $\begin{array}{l}\text { 10-m-long chip channel of black shale above upper nodular barite zone at } \\
\text { sample site } 13\end{array}$ \\
\hline 15 & $90 \mathrm{BT} 149$ & 0.70 & 1.8 & ND & 4 & 10 & 20 & $\underline{9}$ & 5 & 2 & 171 & 16 & 4 & 70 & 70 & 200 & ND & 0.20 & 109 & 0.03 & 0.60 & 0.27 & $\begin{array}{l}\text { 5-m-long chip channel of black shale and nodular chert above nodular barite } \\
\text { zone }\end{array}$ \\
\hline 17 & $90 \mathrm{BT} 1$ & 3.61 & 2.2 & $\underline{8}$ & 9 & 10 & 80 & $\underline{21}$ & ND & 4 & 215 & 20 & 6 & 360 & 102 & 200 & ND & 0.18 & 367 & 0.04 & 0.50 & 0.33 & $\begin{array}{l}\text { Weakly mineralized nodular-barite-bearing shale below massive barite } \\
90 \mathrm{BT} 129 \mathrm{~d} \text {, about } 5 \mathrm{~m} \text { thick }\end{array}$ \\
\hline 18 & $90 \mathrm{BT} 152$ & 0.20 & 2.4 & ND & 30 & 10 & 70 & 18 & 10 & 4 & 188 & 82 & ND & 210 & 15 & 500 & ND & 0.45 & 483 & 0.11 & 3.78 & 0.84 & 3-m-long chip channel of black shale horizon below massive barite at site 16 \\
\hline
\end{tabular}

Analyses of barium by Chemax Labs Ltd. (Chemex) using carbonate-fusion gravimetric technique; of $\mathrm{Ag}, \mathrm{Co}, \mathrm{Cu}, \mathrm{Fe}, \mathrm{Mn}, \mathrm{Mo}, \mathrm{Ni}, \mathrm{Pb}$, and $\mathrm{Zn}$ by Chemex using ICP full assay digestion (AES) techniques; analyses of $\mathrm{Au}$, Al, As, Be, Bi, Ca, Cd, Cr, Ga, $\mathrm{Hg}$, K, La, Mg, Mo, Na, Ni, $\mathrm{P}, \mathrm{Sb}, \mathrm{Sc}, \mathrm{Sr}, \mathrm{Ti}, \mathrm{Tl}, \mathrm{U}, \mathrm{V}$, and $\mathrm{W}$ by Chemex using standard ICP with limited-digestion techniques. Au, Be, Cd, Ga, La, Sb, Sc, Ti, and $\mathrm{Tl}$ were below the limits of detection in all submitted samples. BT samples = T.K. Bundtzen; WG samples = W.G. Gilbert; and GL samples = G.M. Laird. 
Table 2. Comparisons between Gagaryah deposit and other selected stratiform barite-sulfide deposits in North American Cordillera

\begin{tabular}{|c|c|c|c|c|c|c|c|c|c|c|}
\hline \multirow[b]{2}{*}{$\begin{array}{l}\text { Name, } \\
\text { location, } \\
\text { reference }\end{array}$} & \multicolumn{3}{|c|}{ Yukon Territory } & \multicolumn{6}{|c|}{ Alaska } & \multirow{2}{*}{$\begin{array}{l}\text { Nevada } \\
\text { East Northumberland, } \\
\text { (Graber and Chafetz, } \\
\text { 1990) }\end{array}$} \\
\hline & $\begin{array}{l}\text { Tom/Jason deposits (MacMillan Pass, } \\
\text { Turner and Goodfellow, 1990, } \\
\text { McClay and Bidwell, 1986) }\end{array}$ & $\begin{array}{l}\text { Walt/Hess/Tryala deposits } \\
\text { (Abbott and Turner, 1990) }\end{array}$ & $\begin{array}{l}\text { North Gary deposit, } \\
\text { (Abbott and } \\
\text { Turner, 1990) }\end{array}$ & $\begin{array}{l}\text { Gagaryah deposit } \\
\text { (his study) }\end{array}$ & $\begin{array}{l}\text { Nimiutuk deposit, } \\
\text { western Brooks } \\
\text { Range (Mayfield } \\
\text { and others, } \\
\text { 1979) }\end{array}$ & $\begin{array}{l}\text { Red Dog } \\
\text { (Lange and } \\
\text { others, } \\
\text { 1985; } \\
\text { Moore and } \\
\text { others } \\
1986 \text { ) }\end{array}$ & $\begin{array}{l}\text { Atigun Canyon, } \\
\text { Brooks Range } \\
\text { (Paris, 1977) }\end{array}$ & $\begin{array}{l}\text { Castle Island } \\
\text { deposits, South- } \\
\text { east Alaska } \\
\text { (Berg, 1984) }\end{array}$ & $\begin{array}{l}\text { Glacier Creek } \\
\text { near Haines } \\
\text { (Hawley, 1976) }\end{array}$ & \\
\hline Age & Middle to Late Devonian & Early to Middle Devonian & $\begin{array}{l}\text { Frasnian(?) or } \\
\text { early Late Devonian }\end{array}$ & $\begin{array}{l}\text { Middle to early } \\
\text { Late Devonian } \\
\text { (Frasnian }\end{array}$ & $\begin{array}{l}\text { Mississippian } \\
\text { or Pennsylvanian }\end{array}$ & $\begin{array}{l}\text { Mississip- } \\
\text { pian and } \\
\text { Pennsylvanian }\end{array}$ & Permian & Upper Triassic & Upper Triassic & Devonian \\
\hline $\begin{array}{l}s^{34} \text { isotope } \\
\text { data } \\
\text { (barite } \\
\text { only) }\end{array}$ & \pm 20.0 to +24.0 & NA & $\mathrm{NA}$ & $\begin{array}{l}+24.0 \text { and }+28.0 \\
\text { (massive and } \\
\text { nodular) }\end{array}$ & NA & $\begin{array}{l}+17.4 \text { to }+27.8 \\
\text { (massive variety) }\end{array}$ & NA & NA & & $\begin{array}{l}+20.9 \text { to } \\
\text { (all types) }\end{array}$ \\
\hline $\begin{array}{l}\text { Base } \\
\text { metal/ } \\
\text { trace } \\
\text { element } \\
\text { content }\end{array}$ & $\begin{array}{l}\text { Lead-zinc-silver-barium } \\
\text { in direct association; low } \\
\text { phosphorous; high organic } \\
\text { carbon }\end{array}$ & $\begin{array}{l}\text { No base metals; high } \\
\text { organic carbon }\end{array}$ & $\begin{array}{l}\text { Barium only, high organic } \\
\text { carbon }\end{array}$ & $\begin{array}{l}\text { Major barium, no } \\
\text { phosphorous; low } \\
\text { strontium. No base } \\
\text { metals; slightly } \\
\text { elevated vanadium }\end{array}$ & Barium only & $\begin{array}{l}\text { Lead, zinc, silver, } \\
\text { cadmium, barium }\end{array}$ & Barium only & $\begin{array}{l}\text { Mainly barium, } \\
\text { with zinc, low } \\
\text { lead, anomalous } \\
\text { silver }\end{array}$ & $\begin{array}{l}\text { Barium, zinc, } \\
\text { silver }\end{array}$ & $\begin{array}{l}\text { Abundant; barium, } \\
\text { phosphate (nodules) } \\
\text { and silica }\end{array}$ \\
\hline $\begin{array}{l}\text { Lithologic } \\
\text { package }\end{array}$ & $\begin{array}{l}\text { Shale, conglomerate, sandstone, } \\
\text { limestone, barium-rich carbonates } \\
\text { present with hhert-rich andesitic } \\
\text { volcanic rocks nearby }\end{array}$ & $\begin{array}{l}\text { Carbonaceous shale, limestone } \\
\text { siliceous argillite }\end{array}$ & $\begin{array}{l}\text { Fine sandstone, argillite, } \\
\text { barium carbonate, } \\
\text { diamictite }\end{array}$ & $\begin{array}{l}\text { Carbonaceous shale, } \\
\text { minor siltstone, } \\
\text { argillaceous chert. } \\
\text { No volcanic rocks }\end{array}$ & Shale and chert & $\begin{array}{l}\text { Shale, chert, exha- } \\
\text { lite keratophyre } \\
\text { voleanic rocks } \\
\text { nearby }\end{array}$ & $\begin{array}{l}\text { Black, siderite- } \\
\text { rich shale and } \\
\text { chert }\end{array}$ & $\begin{array}{l}\text { Metamorphosed } \\
\text { limestone, sand- } \\
\text { stone, greenstone }\end{array}$ & $\begin{array}{l}\text { Barite nested } \\
\text { in metabasalt }\end{array}$ & $\begin{array}{l}\text { Mainly Slaven Chert } \\
\text { with minor clastic } \\
\text { rocks }\end{array}$ \\
\hline $\begin{array}{l}\text { Barite } \\
\text { morpho- } \\
\text { logy }\end{array}$ & $\begin{array}{l}\text { Massive to laminated, dark gray } \\
\text { to white }\end{array}$ & $\begin{array}{l}\text { Massive to laminated; rarely } \\
\text { nodular, dark gray to light } \\
\text { gray }\end{array}$ & $\begin{array}{l}\text { Nodular, laminated and } \\
\text { massive light gray } \\
\text { barite with celestite }\end{array}$ & $\begin{array}{l}\text { Nodular, laminated, } \\
\text { and massive, light- } \\
\text { gray to white } \\
\text { barite }\end{array}$ & $\begin{array}{l}\text { Light-gray, } \\
\text { massive barite }\end{array}$ & $\begin{array}{l}\text { Vein type, } \\
\text { quarty exhalite, } \\
\text { and massive light- } \\
\text { gray barite }\end{array}$ & $\begin{array}{l}\text { Nodular and } \\
\text { laminated black } \\
\text { to blue barite }\end{array}$ & $\begin{array}{l}\text { Massive, light- } \\
\text { gray, and black } \\
\text { barite }\end{array}$ & $\begin{array}{l}\text { Massive layered, } \\
\text { gray-green to } \\
\text { white barite }\end{array}$ & $\begin{array}{l}\text { Nodular massive } \\
\text { and composite dark- } \\
\text { gray or black barite } \\
\text { with phosphate } \\
\text { nodules }\end{array}$ \\
\hline $\begin{array}{l}\text { Para- } \\
\text { genetic } \\
\text { and } \\
\text { inter- } \\
\text { pretive } \\
\text { classifi- } \\
\text { cation }\end{array}$ & $\begin{array}{l}\text { Proximal sedimentary exhalative } \\
\text { barite peripheral to sulfide-rich } \\
\text { core adjacent to vent-fault } \\
\text { complex }\end{array}$ & $\begin{array}{l}\text { Both proximal and distal 'sedex' } \\
\text { depositis derived from vent complex } \\
\text { but below temperatures necessary } \\
\text { to generate base-metal deposity }\end{array}$ & $\begin{array}{l}\text { Distal 'sedex' } \\
\text { deposit }\end{array}$ & $\begin{array}{l}\text { Distal exhalative } \\
\text { (sedex) deposit }\end{array}$ & $\begin{array}{l}\text { Distal sedex(?) } \\
\text { barite }\end{array}$ & $\begin{array}{l}\text { Volcanogenic ex- } \\
\text { halative barite- } \\
\text { base-metal } \\
\text { deposition }\end{array}$ & $\begin{array}{l}\text { Primary } \\
\text { sedimentary } \\
\text { barite }\end{array}$ & $\begin{array}{l}\text { Proximal 'Kuroko' } \\
\text { volcanogenic barite- } \\
\text { base-metal deposit }\end{array}$ & $\begin{array}{l}\text { Proximal Kuroko } \\
\text { barite-base-metal } \\
\text { deposition directly } \\
\text { over submarine } \\
\text { vents in thick } \\
\text { metabasaltic } \\
\text { buildup }\end{array}$ & Sedimentary barite \\
\hline
\end{tabular}




\section{REFERENCES}

Abbott, J.G., and Turner, R.J., 1990, Character and paleotectonic setting of Devonian stratiform sedimenthosted zinc, lead, barium deposits, MacMillan Fold Belt, Yukon, in Abbott, J.G., and Turner, R.J., Mineral deposits of the northern Canadian Cordillera, Yukon and northeastern British Columbia: 8th IAGOD Symposium Field Trip Guidebook 14, p. 99-136.

Berg, H.C., 1984, Regional geologic summary, metallogenesis, and mineral resources of southeastern Alaska: U.S. Geological Survey Open-file Report 84-252, 298 p., scale 1:1,000,000, 1 sheet.

Bundtzen, T.K., and Gilbert, W.G., 1983, Outline of geology and mineral resources of upper Kuskokwim region, Alaska, in Reed, K.M., and Mull, C.G., eds., WesternAlaska geology and resource potential: Journal of the Alaska Geological Society, v. 3, p. 101-117.

Bundtzen, T.K., and Henning, M.W., 1978, Barite in Alaska: Alaska Division of Geological and Geophysical Surveys Mines and Geology Bulletin, v. 27, no. 4, p. 1-4.

Bundtzen, T.K., Kline, J.T., Smith, T.E., and Albanese, M.D., 1988, Geology of the McGrath A-2 Quadrangle: Alaska Division of Geological and Geophysical Surveys Professional Report 91, 22 p., scale 1:63,360, 1 sheet.

Claypool, G.E., Holser, W.T., Kaplan, I.R., Sakai, H., and Zak, H., 1980, The age curves of sulfur and oxygen isotopes in marine seawater and their mutual interpretation: Chemical Geology, v. 28, p. 199-260.

Cox, D.P., and Singer, D.A., 1986, Mineral deposit models: U.S. Geological Survey Bulletin 1693, 379 p.

Gilbert, W.G., and Bundtzen, T.K., 1984, Stratigraphic relationship between Dillinger and Mystic terranes, western Alaska Range, Alaska [abs.]: Geological Society of America Abstracts with Programs, v. 16, no. 5, p. 286.

Gilbert, W.G., Bundtzen, T.K., Kline, J.T., and Laird, G.M., 1990, Preliminary geology and geochemistry of southwest part of the Lime Hills D-4 Quadrangle, Alaska: Alaska Division of Geological and Geophysical Surveys Report of Investigations 90-6, 4 p., scale 1:63,360, 1 sheet.

Gilbert, W.G., Solie, D.N., and Kline, J.T., 1989, Geologic map of the McGrath B-3 Quadrangle,Alaska:Alaska Division of Geological and Geophysical Surveys Professional Report 102, scale 1:633,360, 2 sheets.

Gordey, S.P., Abbott, J.G., and Orchard, M.J., 1982, Devono-Mississippian (Earn Group) and younger strata in east-central Yukon, in Current ResearchPart A, Geological Survey of Canada, Paper 81-1A, p. 396-398.
Graber, K.K., and Chafetz, H.S., 1990, Petrography and origin of bedded barite and phosphate in the Devonian Slaven chert of central Nevada: Journal of Sedimentary Petrology, v. 60, no. 6, p. 897-911.

Hawley, C.C., 1976, Exploration and distribution of stratiform sulfide deposits in Alaska, in Miller, T.P., ed., Recent and ancient sedimentary environments in Alaska: Anchorage, Alaska Geological Society Symposium Proceedings, Anchorage, 1976, p. T1-T28.

Herreid, Gordon, Bundtzen, T.K., and Turner, D.L., 1978, Geology and geochemistry of the Craig A-2 Quadrangle, southeastern Alaska: Alaska Division of Geological and Geophysical Surveys Geologic Report 48, 48 p.

Jones, D.L., Silberling, N.J., Gilbert, W.G., and Coney, P.N., 1982, Character, distribution, and tectonic significance of accretionary terranes in central Alaska Range, Alaska: Journal of Geophysical Research, v. 87, no. B5, p. 3709-3717.

Krauskopf, K.B., 1969, Introduction to geochemistry: New York, McGraw-Hill Book Company, p. 638-640.

Krige, D.G., and Ueckermann, H.J., 1963, Value contours and improved regression techniques for ore reserve valuations: South African Institute of Mining and Metallurgy Journal, v. 63, p. 429-452.

Lange, I.M., Nokleberg, W.J., Plahuta, J.T., Krouse, H.R., and Doe, B.R., 1985, Geologic setting, petrology, and geochemistry of stratiform zinc-lead-barium deposits, Red Dog Creek and Drenchwater Creek areas, northwestern Brooks Range, Alaska: Economic Geology, v. 80, no. 9, p. 1896-1926.

Lydon, J.W., Goodfellow, W.D., and Jonasson, I.R., 1985, Ageneral genetic model for stratiform barite deposits of the Selwyn Basin, Yukon Territory and District of MacKenzie, in Current Research—PartA, Geological Survey of Canada Paper 85-1A, p. 651-660.

Mayfield, C.F., Curtis, S.M., Ellersieck, I.F., and Tailleur, I.L., 1979, The Ginny Creek zinc-lead-silver and Nimiiuktuk barite deposits, northwestern Brooks Range, Alaska, in Johnson, K.M., and Williams, J.R., eds., The United States Geological Survey in Alaska: Accomplishments during 1978: U.S. Geological Survey Circular 804-B, p. B11-B13.

McClay, K.R., and Bidwell, G., 1986, Geology of the Tom deposit, MacMillan Pass, Yukon Territory, in Morin, J.A., ed., Mineral deposits of the northern Canadian Cordillera, Canadian Institute of Mining and Metallurgy Special Volume 37, p. 100-114.

McKinstry, H.E., 1948, Mining geology: New York, Prentice-Hall, Inc., 680 p. 
Moore, D.W., Young, L.E., Modene, J.S., and Plahuta, J.T., 1986, Geologic setting and genesis of the Red Dog zinc-lead-silver deposit, western Brooks Range, Alaska: Economic Geology, v. 81, no. 7, p. 1696-1727.

Nokleberg, W.J., Bundtzen, T.K., Berg, H.C., Brew, D.A., Grybeck, D., Robinson, M.S., Smith, T.E., and Yeend, Warren, 1987, Significant metalliferous lode deposits and placer districts of Alaska: U.S. Geological Survey Bulletin 1786, 104 p.

Paris, Chester, 1977, Models of barite deposition with reference to the barite occurrence of Atigun Canyon, central Brooks Range, Alaska: Fairbanks, University of Alaska unpublished report, 45 p.

Patterson, J.A., 1959, Estimating ore reserves follows logical steps: Engineering and Mining Journal, v. 160 , p. $112-115$.
Poole, F.G., 1988, Stratiform barite in Paleozoic rocks of western United States: Proceedings of the Seventh Quadrennial IAGOD Symposium, Stuttgart, E. Schweizerbart'sche Verlagsbuchhandlung Nagele v. Obermiller, p. D7000-D7010.

Reed, B.L., and Nelson, S.W., 1980, Geologic map of the Talkeetna Quadrangle, Alaska: U.S. Geological Survey Miscellaneous Investigations Map I-1174, scale $1: 250,000,1$ sheet.

Turner, R.J.W., and Goodfellow, W.G., 1990, Bariumcarbonate bodies associated with the Walt (Cathy) stratiform barium deposit, Selwyn Basin, Yukon: A possible vent complex associated with a Middle Devonian sedimentary exhalative deposit, in Current Research-Part E, Geological Survey of Canada Paper 90-1E, p. 309-319. 


\title{
GEOLOGY AND GEOCHEMISTRY OF TATLAWIKSUK HOT SPRINGS, A NEWLY DISCOVERED GEOTHERMAL AREA IN WESTERN ALASKA
}

\author{
By \\ Thomas K. Bundtzen, ${ }^{1}$ Shirley E. Liss, ${ }^{1}$ and Ellen E. Harris ${ }^{1}$
}

\section{INTRODUCTION}

In June 1989, in the upper Kuskokwim River area of western Alaska, a previously unreported geothermal area was briefly evaluated (fig. 1). This report describes the bedrock geology, spring geochemistry, and potential of the geothermal area-herein named Tatlawiksuk Hot Springs after the nearby Tatlawiksuk River.

\section{HISTORY, GEOGRAPHY, AND ACCESS}

Tatlawiksuk Hot Springs is located approximately $102 \mathrm{~km}$ in a S. $4^{\circ} \mathrm{W}$. direction from McGrath, the region's largest transportation and supply center. The geothermal area covers 4 ha at an elevation of $146 \mathrm{~m}$ along a small, unnamed stream in NW 1/4, sec. 31, T. 23 N., R. 35 W., Seward Meridian, McGrath A-6 Quadrangle (fig. 1). The stream flows south $6 \mathrm{~km}$ to Tatlawiksuk River, which in turn flows southwest about $120 \mathrm{~km}$ to the Kuskokwim River about $90 \mathrm{~km}$ upstream from the village of Stony River.

The hot springs are situated in a wooded lowland and wetland immediately south of an isolated, $90-\mathrm{km}^{2}$ upland, herein informally referred to as Tatlawiksuk Hills. Elevations in the study area range from $432 \mathrm{ft}$ (132 m) along Tatlawiksuk River to $1,510 \mathrm{ft}(460 \mathrm{~m})$ in the western Tatlawiksuk Hills. The area is transitional between the Kuskokwim Mountains, Big River Hills, and Alaska Range-Lyman Hills provinces (Wahrhaftig, 1965).

The geothermal area is remote and is separated from the Kuskokwim Mountains $29 \mathrm{~km}$ to the west by alternating belts of peat-rich wetlands and deciduous to coniferous forests. No trails or FAA-approved airports exist in the study area; the nearest airstrip is at White Mountain mercury mine $51 \mathrm{~km}$ east-northeast of Tatlawiksuk Hot Springs near Big River.

Previous regional and statewide surveys of geothermal resources do not mention a geothermal field in or near Tatlawiksuk Hot Springs (Waring, 1917; Miller, 1973;

${ }^{1}$ Alaska Division of Geological and Geophysical Surveys, 794 University Avenue, Fairbanks, Alaska 99709-3645.
Miller and others, 1975; Motyka and others, 1983). The nearest geothermal area is at Chuilnik Springs about 140 $\mathrm{km}$ to the southwest.

The presence of Tatlawiksuk Hot Springs was first suspected during casual conversations with air-taxi pilots, who noted conspicuous water vapor or steam while flying over the Selatna-Tatlawiksuk River area. However, repeated DGGS overflights of a $200 \mathrm{~km}^{2}$ area from 1984 to 1988 failed to locate the steam anomaly. While making a reconnaissance overflight on June 20, 1989, Bundtzen noted lush vegetation, conspicuous mineral precipitate, and a steam plume; a geothermal area was confirmed during a visit to the site on June 21, 1989.

\section{REGIONAL GEOLOGY}

About 85 percent of the exposed bedrock near the thermal area consists of micaceous, medium-gray, lithic sandstone (Kkss), and argillite and siltstone (Kksh) of the Kuskokwim Group (fig. 1) (Cady and others, 1955). The age of the Kuskokwim Group is determined by Cenomanian and Turonian pelecypod fossils; however, rarer fossils as young as Maastrichtian age have also been identified.

Intruding the Cretaceous clastic rocks are poorly exposed, sill-like bodies of biotite quartz monzonite and biotite-hornblende quartz diorite (Tkqm). No radiometric age control is available for the immediate geothermal area; however, a ${ }^{40} \mathrm{~K}-{ }^{40} \mathrm{Ar}$ date of $61.1 \pm 1.8 \mathrm{Ma}$ (sample site 78BT321) was obtained for geologically and geochemically similar plutonic rocks in the Selatna Hills about 10 $\mathrm{km}$ north of Tatlawiksuk Hills. We believe that plutonic rocks in the study area are probably early Tertiary, which is typical of many plutonic complexes of the central Kuskokwim area (Bundtzen and Miller, in press).

A conspicuous $25-\mathrm{km}^{2}$ area of dark-gray, massive, recrystallized, chlorite-biotite, porphyroblastic hornfels (Kkhf) underlies most of the central Tatlawiksuk Hills. This hornfels aureole indicates that the small sill-like plutonic rocks of quartz monzonite and diorite (Tkqm) are manifestations of a much larger intrusive mass at depth. 

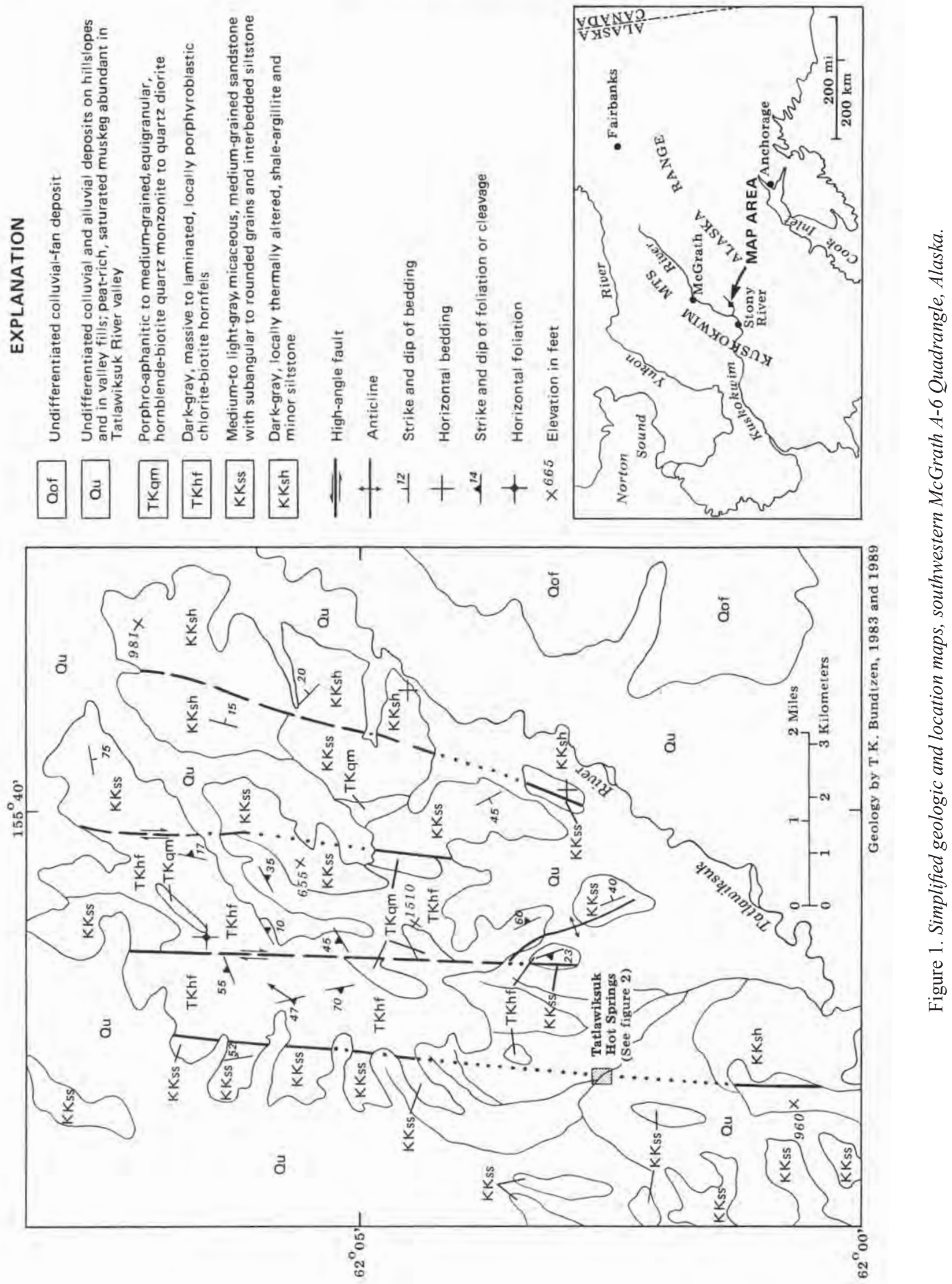
Quaternary deposits are subdivided by photogeology and ground reconnaissance. An areally extensive colluvial-alluvial fan-terrace complex (Qof) is derived from the higher, more dissected Lyman Hills east of the study area (Gilbert, 1981). Most of the area, including Tatlawiksuk Hot Springs, is underlain by an undifferentiated unit of alluvial, colluvial, and eolian deposits $(\mathrm{Qu})$, including talus and alluvial-colluvial aprons on moderate to steep hill slopes, ice-rich eolian deposits of silt and fine sand in valley fills, and silt fans overlain by poorly drained wetlands.

Cretaceous sedimentary rocks have been deformed by compression into open to isoclinal folds-many during post-early Tertiary time. A younger, distinctive set of N. 5 to $10^{\circ}$ E.-striking, high-angle faults cut all bedrock units. One such fault juxtaposes hornfels and unaltered sandstone and siltstone in the western Tatlawiksuk Hills; this fault continues south directly through the Tatlawiksuk Hot Springs geothermal area (fig. 1).

Many hot springs in interior and western Alaska are associated with faulted intrusive contacts (Miller, 1973; Miller and others, 1975). Structurally weak zones in competent rock units such as granitic plutons provide pathways through which circulating meteoric waters can be heated at depth and moved upward to the surface.

\section{SURFACE FEATURES}

A4-ha surface area in the vicinity of Tatlawiksuk Hot Springs contains anomalous vegetation, hydrothermally altered bedrock float and Quaternary alluvium, and several bubbling hot-water anomalies (fig. 2). Anomalous vegetation consists of lush meadow grasses, ferns, victory onion (Allium victorialus), wild chive (Allium schoenoprasum) and skunk cabbage(?) (Lysichiton americanum). Thick mats of green algae cover bubbling seeps and wetlands, where measured water temperatures exceed $30^{\circ} \mathrm{C}$ (fig. 2).

Light, varicolored gray-to-limonitic, sinterous hydrothermal-mineral precipitate cements gravelly stream alluvium in the southern part of the map area (fig. 2). However, no quantitative identifications of alteration minerals or precipitate were completed. In cutbanks along the south-flowing stream that bisects the area, alluvium appears to be cemented or silicified into a hard silicrete, indicating a much larger area of hydrothermal alteration is present beneath vegetative cover.

Tatlawiksuk Hot Springs consist of three distinct hot-water anomalies in an elongate, 60 - by $180-\mathrm{m}$ area oriented along a N. 5 to $10^{\circ}$ E. trend parallel to the highangle fault zone that is traceable through the geothermal area.

One of the three bubbling hot-water anomalies (figs. 2 and 3 ) is cribbed with timbers that appear to be old, notched, square sets in the style of pre-World War I interior Alaska thermal spring developments at Circle, Tolovana, and Manley Hot Springs (Waring, 1917). Therefore, we speculate that Tatlawiksuk Hot Springs was developed during the gold-rush era in the early 20th century, but after the discoveries of gold in the nearby Innoko district in 1906 and Iditarod district in 1909 (Bundtzen and Kline, 1986).

\section{GEOCHEMISTRY AND GEOTHERMOMETRY}

Temperatures of the spring waters ranged from $20^{\circ}$ to $68^{\circ} \mathrm{C}$. The $\mathrm{pH}$ values measured in the field ranged from 7.58 to $8.41(\mathrm{n}=4)$ for the hottest spring. Flow rates could not be measured due to the shallow channels, numerous seeps coming from the gravels, and the probable existence of seeps directly into the divided stream bed. Gas bubbled vigorously from the hottest pools, where the odor of $\mathrm{H}_{2} \mathrm{~S}$ was strongest. Chemical analyses of hot-spring and creek waters are given in table 1. Alkalinity $\left(\mathrm{HCO}_{3}\right)$ must be considered a minimum because the sample was not titrated until it was returned to the lab. Normally, the chemical-charge balance for hot-springs systems should be $0 \pm 5$ percent. The high chemical-charge balance of +10.5 percent obtained from Tatlawiksuk Hot Springs (table 1) may be due to (1) loss of $\mathrm{CO}_{2}$ during transit of the sample or (2) an excess of cations-especially sodium-because analyzed values have a standard deviation of 10 percent. For example, if sodium was lowered from 110 ppm to $100 \mathrm{ppm}$ (table 1), the resultant chemical-charge balance could change from +10.5 to +2.8 percent.

Chemically, Tatlawiksuk Hot Springs is classified as a fairly alkaline, low-chlorine, sodium-bicarbonate spring (Mahon and others, 1981), comparable to other Alaska hot springs that are related to granitic plutons. These low-temperature geothermal systems are not normally associated with active volcanism. Chemical constituents in the water were probably leached from intrusive host rocks. Except for fluorine, which should be $2.5 \mathrm{ppm}$ or less (Tatlawiksuk Hot Springs had a fluorine value of 22 ppm), water from Tatlawiksuk Hot Springs meets Alaska drinking-water standards. High-fluoride drinking water is known to cause brown discoloration in teeth of children and adolescents but does not affect adults. Elevated fluorine values in Tatlawiksuk Hot Springs might be derived from dissolution of biotite from plutonic rocks or hornfels (Tkqm, TKhf) or, alternatively, from dissolution of fluorite in the pluton or in associated mineral deposits.

Reservoir temperatures were estimated using silica and cation geothermometers (table 2). All calculations are based on temperature-dependent water-rock reactions and assume equilibrium is reached in the reservoir. 


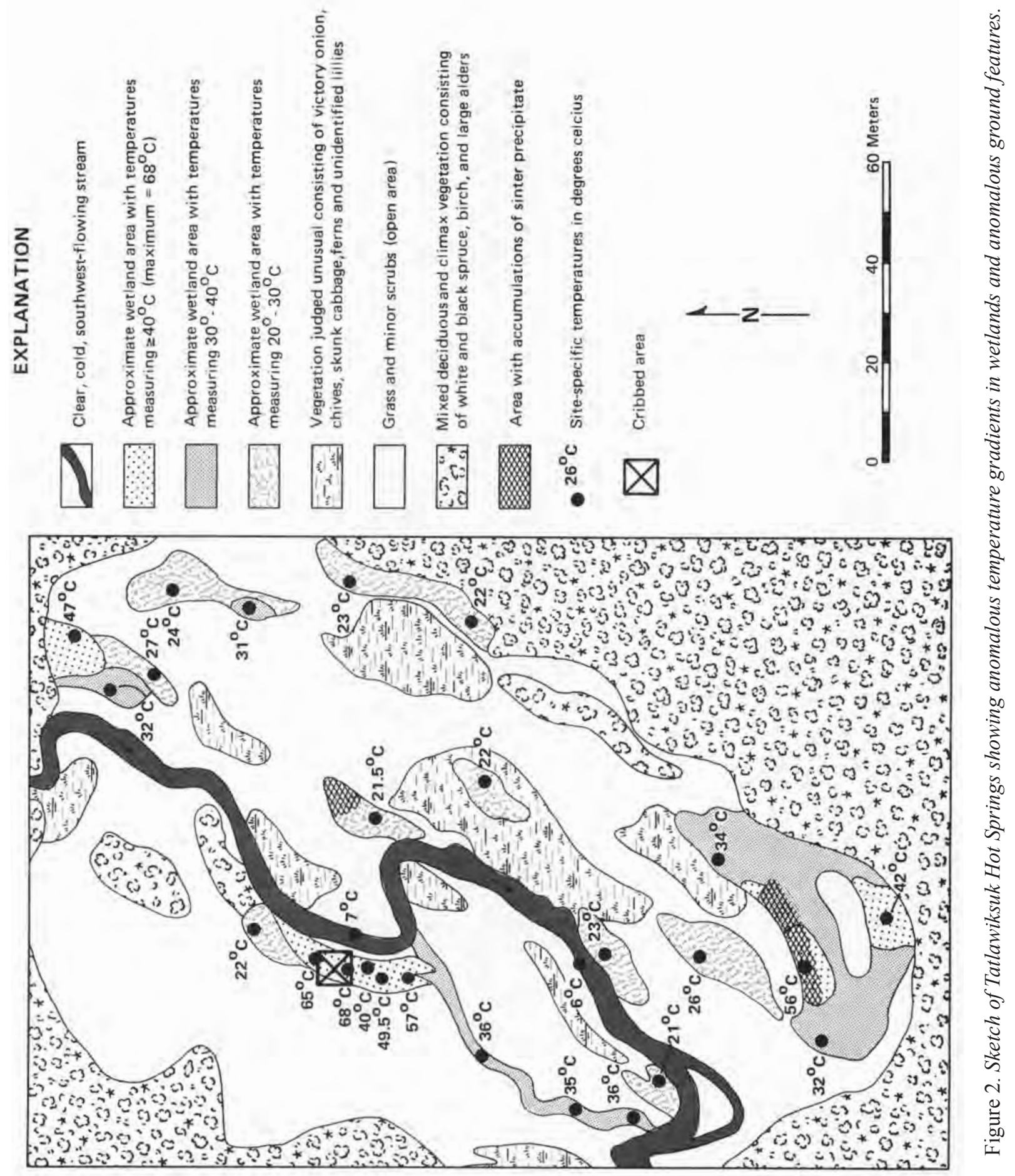




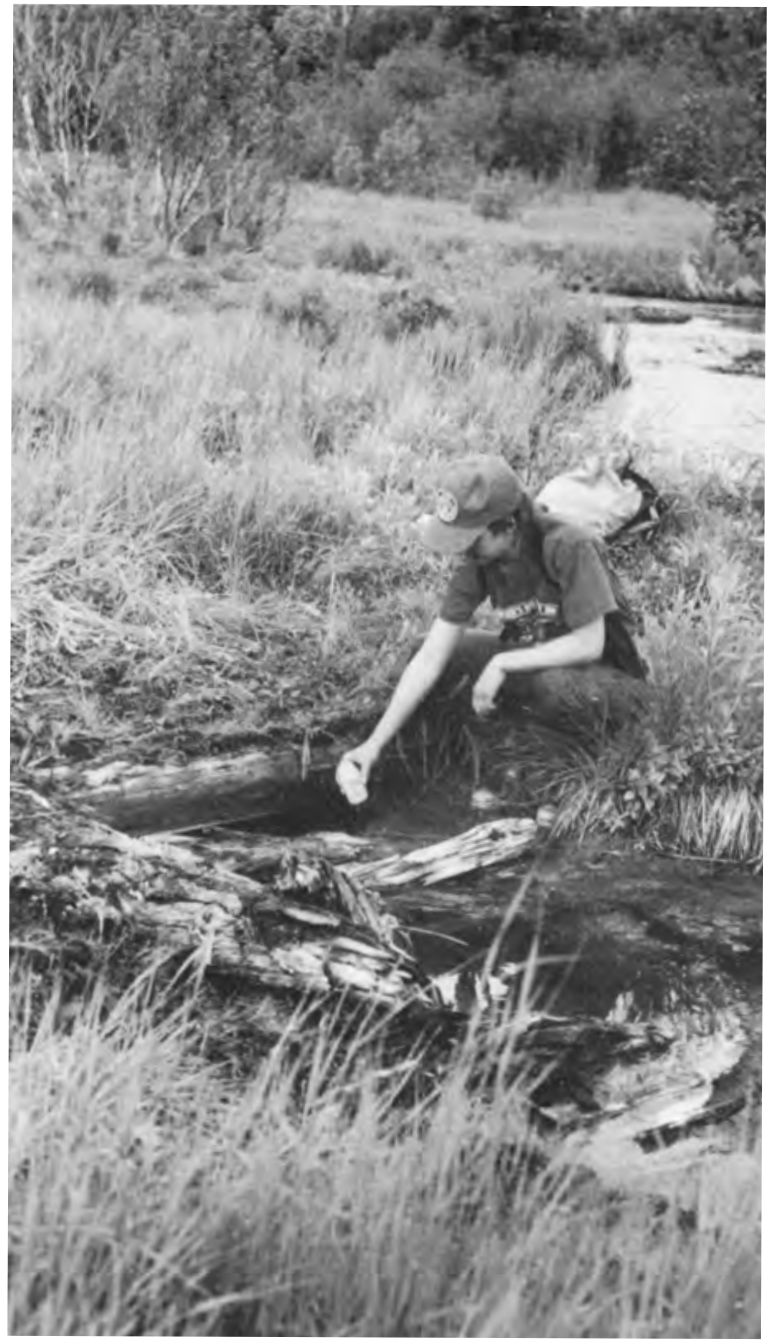

Figure 3. Remains of former wood cribbing around main discharge area of Tatlawiksuk Hot Springs. Southflowing, cold stream in right background.

The silica geothermometer uses the absolute (total) silica value in solution and assumes that geothermal waters remain undiluted during ascent to the surface. According to Fournier (1981), quartz appears to control the dissolved-silica concentration in geothermal waters exceeding $150^{\circ} \mathrm{C}$, and chalcedony controls aqueous-silica content for lower temperatures. However, in granitic terranes like Tatlawiksuk Hot Springs, quartz may control aqueous silica to temperatures as low as $90^{\circ} \mathrm{C}$.
The alkaline nature of Tatlawiksuk Hot Springs $(\mathrm{pH}=8.41)$ necessitates reduction of the silica value by 10 percent before the silica geothermometer can be reliably applied (Fournier, 1981). Thus, reservoir temperatures for uncorrected silica values range from $97^{\circ}$ to $125^{\circ} \mathrm{C}$, and calculations based on the $\mathrm{pH}$-corrected silica value range from $91^{\circ}$ to $120^{\circ} \mathrm{C}$.

The cation geothermometer used in this study calculates reservoir temperatures based on ratios of $\mathrm{Na}-\mathrm{K}$ or Na-K-Ca (table 2). The Na-K method yields temperatures ranging from $146^{\circ}$ to $152^{\circ} \mathrm{C}$, whereas the $\mathrm{Na}-\mathrm{K}-\mathrm{Ca}$ method provides temperature ranges of $128^{\circ}$ to $130^{\circ} \mathrm{C}$. Hence, the Na-K-Ca geothermometer more closely agrees with results obtained by the silica-quartz conductive geothermometer. We conclude that $125^{\circ} \mathrm{C}$ $\pm 5^{\circ}$ is a good estimate of reservoir temperatures for Tatlawiksuk Hot Springs.

Miller and others (1975) determined that the source of many interior Alaska hot springs is meteoric waters that have circulated several kilometers down faults or fractures in competent host rocks. The standard geothermal gradient of $25^{\circ} \mathrm{C}$ per km, coupled with the estimated reservoir temperature (table 2), indicates that meteoric waters have circulated to depths of 5 to $6 \mathrm{~km}$ before emanating to the surface at Tatlawiksuk Hot Springs.

\section{GEOTHERMAL POTENTIAL}

Tatlawiksuk Hot Springs is typical of many interior Alaska geothermal areas, including the Chena, Tolovana, Kanuti, and Melozi geothermal areas. All of these hot springs are associated with faulted contacts between granitic plutons and less-competent host lithologies. Reservoir temperatures calculated for Tatlawiksuk Hot Springs probably preclude a super-heated steam environment capable of generating electric power. In addition, the remoteness of the site will limit recreational or agricultural applications in the near future.

\section{ACKNOWLEDGMENTS}

Discussions with pilots Don Harris (in 1984), William Lynch (in 1985), and Jim Williams (in 1988) encouraged our investigation. We thank reviewers Roman J. Motyka (DGGS) and Daniel B. Hawkins (University of Alaska Fairbanks, retired) for substantially improving this report. 
Table 1. Geochemistry of waters from Tatlawiksuk Hot Springs. All analyses in ppm

\begin{tabular}{|c|c|c|}
\hline Constituent & Hot spring & Cold stream \\
\hline $\mathrm{T}$ & $68^{\circ} \mathrm{C}$ & $7^{\circ} \mathrm{C}$ \\
\hline $\mathrm{pH}$ & 8.4 & $\mathrm{nd}^{\mathrm{a}}$ \\
\hline $\mathrm{SiO}_{2}^{\mathrm{b}}$ & 80.0 & 6.2 \\
\hline $\mathrm{Na}^{\mathrm{c}}$ & 110.0 & 2.25 \\
\hline$K^{\mathrm{d}}$ & 4.15 & 0.17 \\
\hline $\mathrm{Ca}^{\mathrm{e}}$ & 17.8 & 1.70 \\
\hline $\mathrm{Mg}^{\mathrm{e}}$ & 0.64 & 1.25 \\
\hline $\mathrm{Li}^{\mathrm{f}}$ & 0.59 & $\mathrm{nd}^{\mathrm{a}}$ \\
\hline $\mathrm{HCO}_{3}{ }^{\mathrm{g}}$ & 118.0 & $\mathrm{nd}^{\mathrm{a}}$ \\
\hline $\mathrm{SO}_{4}^{\mathrm{h}}$ & 18.4 & 4.2 \\
\hline $\mathrm{Cl}^{\mathrm{i}^{4}}$ & 23.3 & 0.21 \\
\hline $\mathrm{F}^{\mathrm{j}}$ & 22.0 & 0.21 \\
\hline $\mathrm{H}_{2} \mathrm{~S}^{\mathrm{k}}$ & 3.74 & $\mathrm{nd}^{\mathrm{a}}$ \\
\hline Conductance & 490.0 & $\mathrm{nd}^{\mathrm{a}}$ \\
\hline Total dissolved solids & 374.0 & $\mathrm{nd}^{\mathrm{a}}$ \\
\hline Chemical charge balance & $+10.5 \%$ & $\mathrm{nd}^{\mathrm{a}}$ \\
\hline \multicolumn{3}{|l|}{ and $=$ not done } \\
\hline \multicolumn{3}{|c|}{${ }^{\mathrm{b} C o l o r i m e t r i c:}$ formation and reduction of silicomolybdate } \\
\hline \multicolumn{3}{|c|}{ 'Directly coupled plasma technique (DCP), 2,000 ppm K added } \\
\hline \multicolumn{3}{|c|}{${ }^{\mathrm{d} D C P}, 2,000 \mathrm{ppm}$ Na added } \\
\hline \multicolumn{3}{|l|}{${ }^{\mathrm{e}} \mathrm{DCP}, \mathrm{LaCl}_{3}$ added } \\
\hline \multicolumn{3}{|l|}{${ }^{\mathrm{f}} \mathrm{DCP}$} \\
\hline \multicolumn{3}{|c|}{${ }^{g}$ Titration using $\mathrm{H}_{2} \mathrm{SO}_{4}$} \\
\hline \multicolumn{3}{|c|}{${ }^{\text {h}} \mathrm{Conversion}$ to $\mathrm{H}_{2}^{2} \mathrm{SO}_{4}^{4}$; then titration with $\mathrm{BaCl} 2$ in presence of throin indicator } \\
\hline \multicolumn{3}{|c|}{${ }^{\mathrm{i}} \mathrm{Mohr}$ tritration with $\mathrm{AgNO}_{3}$} \\
\hline \multicolumn{3}{|c|}{ Direct reading using specific ion electrode } \\
\hline${ }^{k}$ Preservation with $\mathrm{Zn}$ acetate & & \\
\hline
\end{tabular}

Table 2. Estimated reservoir temperatures for Tatlawiksuk Hot Springs using silica and cation geothermometers ${ }^{\mathrm{a}}$

\begin{tabular}{ccc} 
Geothermometer & Estimated reservoir temperatures (in degrees $\left.{ }^{\circ} \mathrm{C}\right)$ \\
\cline { 3 - 3 } Silica geothermometers & $\mathrm{Si}=80 \mathrm{ppm}$ (as analyzed) & $\mathrm{Si}=72 \mathrm{ppm}(\mathrm{pH}$ corrected) \\
Quartz conductive & 125 & 120 \\
Quartz adiabatic & 122 & 91 \\
Chalcedony & 97 & $\mathrm{Na}=100 \mathrm{ppm} ; \mathrm{K}=4.15 \mathrm{ppm}$ \\
Cation Geothermometers & $\mathrm{Na}=110 \mathrm{ppm} ; \mathrm{K}=4.15 \mathrm{ppm}$ & $(\mathrm{Na}$ reduced $)$ \\
$\mathrm{Na}-\mathrm{K}$ & $($ as analyzed) & 152 \\
$\mathrm{Na}-\mathrm{K}-\mathrm{Ca}$ & 146 & 130
\end{tabular}

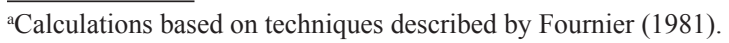




\section{REFERENCES}

Bundtzen, T.K., and Kline, J.T., 1986, Coal, peat, and geothermal resources of the Kuskokwim area plan: Fairbanks, Alaska Division of Geological and Geophysical Surveys Public-data File 86-88, 14 p.

Bundtzen, T.K., and Miller, M.L., in press, Geology and metallogeny of Cretaceous-early Tertiary volcanic and plutonic rocks, Kuskokwim mineral belt, southwestAlaska: 1989 Circum-Pacific Council on Energy and Mineral Resources special paper.

Cady, W.M., Wallace, R.E., Hoare, J.M., and Webber, E.J., 1955, The central Kuskokwim region, Alaska: U.S. Geological Survey Professional Paper 268, 132 p.

Fournier, R.O., 1981, Application of water geochemistry to geothermal exploration and reservoir engineering: in Rybach, L., and Muffler, L.J.P., eds., Geothermal systems: Principles and case histories: New York, John Wiley and Sons, p. 113-120.

Gilbert, W.G., 1981, Preliminary geologic map and geochemical data, Cheeneetnuk River area, Alaska: Alaska Division of Geological and Geophysical Surveys Report of Investigations 153, 10 p., scale $1: 63,360,2$ sheets.
Mahon, W.A.J., Klyen, L.E., and Rhode, M., 1981, Neutral sodium/bicarbonate/sulfate hot water in geothermal systems: Journal of Japan Geothermal Energy Association, v. 17, no. 1, p. 11-14.

Miller, T.P., 1973, Distribution and chemical analyses of thermal springs in Alaska: U.S. Geological Survey Open-file Report 73-187, 5 p., scale 1:2,500,000, 1 sheet.

Miller, Thomas P., Barnes, Ivan, and Patton, W.W., 1975, Geologic setting and chemical characteristics of hot springs in west-central Alaska: Journal of Research of the U.S. Geological Survey, v. 3, no. 2, p. 149-162.

Motyka, R.J., Moorman, M.A., and Liss, S.A., 1983, Geothermal resources of Alaska-1983: Alaska Division of Geological and Geophysical Surveys special report, scale 1:2,500,000, 1 sheet.

Wahrhaftig, Clyde, 1965, Physiographic divisions of Alaska: U.S. Geological Survey Professional Paper 482, 52 p., scale 1:2,500,000, 1 sheet.

Waring, G.A., 1917, Mineral springs of Alaska: U.S. Geological Survey Water-supply Paper 418, 114 p. 


\title{
GEOLOGY AND GEOCHEMISTRY OF THE SLEITAT MOUNTAIN TIN DEPOSIT, SOUTHWESTERN ALASKA
}

By

\author{
Roger E. Burleigh ${ }^{1}$
}

\section{INTRODUCTION}

Significant tin-tungsten mineralization is associated with quartz-topaz-white mica-tourmaline greisen alteration of a multi-unit, peraluminous, granite stock that intrudes Kuskokwim Group flysch of Cretaceous age in southwestern Alaska. The granite stock has a surface exposure of $<2 \mathrm{~km}^{2}$ and is surrounded by an aureole of quartz-topaz-tourmaline-veined hornfels. The stock consists of increasingly altered outer biotite granite, intermediate biotite-muscovite granite, and central zinnwaldite granite units. Mineralization is confined to two east-striking, steeply dipping, tabular lenses of greisen-altered granite interleaved with weakly unaltered granite. North and south greisen zones are estimated to contain an inferred resource of 58 to 96 million $\mathrm{kg}$ of tin in 25.9 million metric tonnes of mineralized rock (Burleigh, 1991).

\section{GEOGRAPHIC LOCATION AND ACCESS}

The Sleitat Mountain tin deposit is located in sec. 31, T. 1 S., R. 45 W., Seward Meridian in the Taylor Mountains Quadrangle (fig. 1) approximately $135 \mathrm{~km}$ northeast of Dillingham and $129 \mathrm{~km}$ west-northwest of Iliamna,

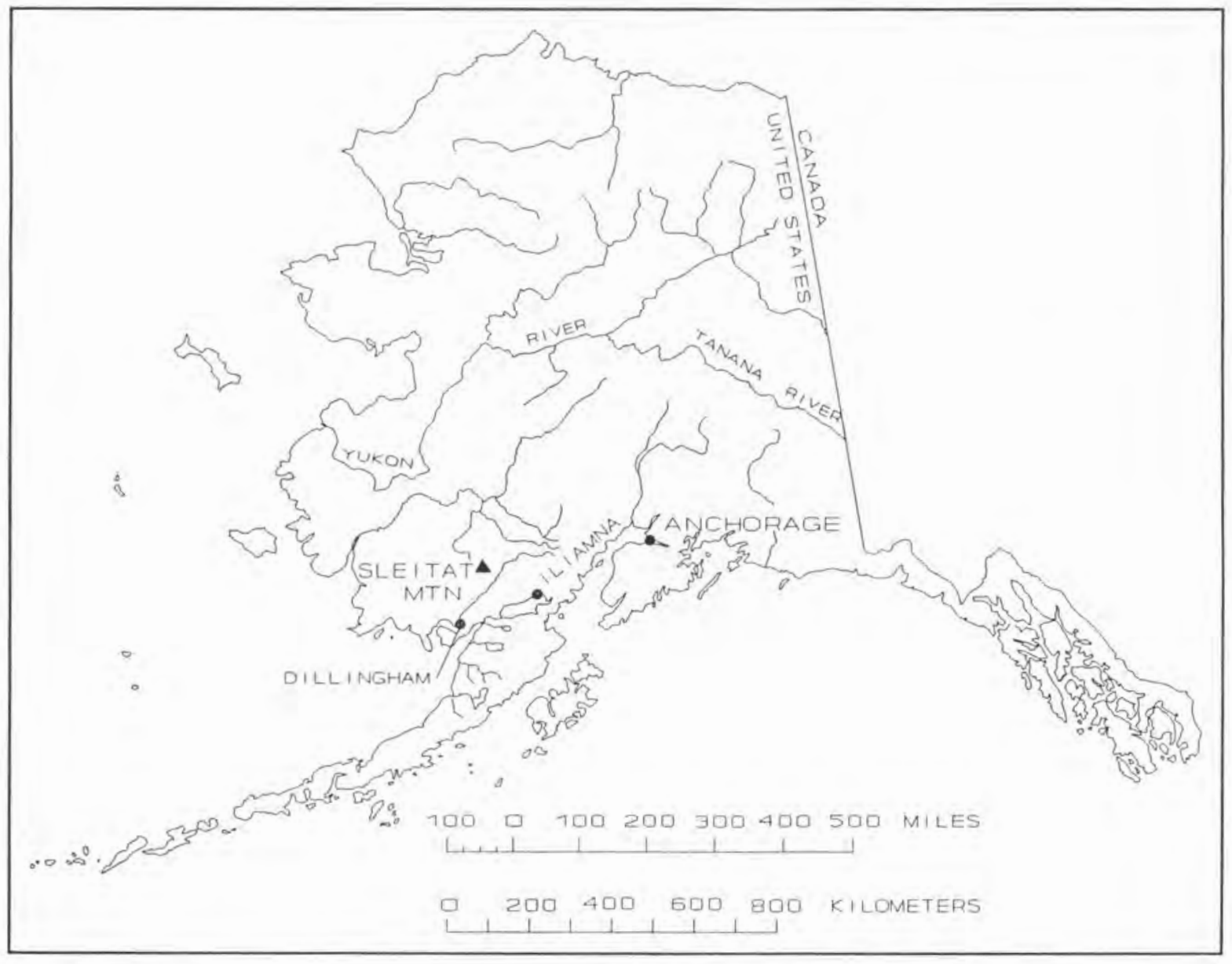

Figure 1. Location map of Sleitat mountain tin deposit.

'U.S. Bureau of Mines, Alaska Field Operations Center, Fairbanks, Alaska 99709. 
Alaska. The deposit occupies the highest part of a small range of elongate, northeast-trending hills in which Sleitat Mountain is the highest peak.

\section{GEOLOGY}

Discovered in 1983, the tin deposit at Sleitat Mountain is the only known major tin mineralization in the region. The granite stock that hosts the tin deposit intrudes Kuskokwim Group flysch deposits of late Early Cretaceous to Late Cretaceous age (Wallace and Engebretson, 1984). The stock is approximately $8 \mathrm{~km}$ northwest of the Mulchatna fault system. A single K-Ar age of $56.8 \pm 2.8 \mathrm{Ma}$ (Teledyne Isotopes Laboratories) was determined for a coarse-muscovite mineral separate from a 0.8 -cm-thick muscovite veinlet related to tin mineralization.

The granite stock at Sleitat Mountain is essentially elliptical and has a mappable thermal aureole. Associated volcanic rocks, if formerly present, have been eroded. Northeast-striking dikes apparently extend outward from the stock parallel to the Mulchatna fault.

At least two types of felsic dike rock are present on all sides of the stock. Contact relations of the dikes to the stock are obscure, so the relative timing of their emplacement is unknown. A hornfels aureole produced by thermal metamorphism of the flysch generally extends 460 to $610 \mathrm{~m}$ into country rock surrounding the stock.

\section{Igneous Petrology}

Igneous rocks of the Sleitat granite stock consist of three units that are mineralogically, petrologically, and geochemically distinct. Granitic units are only mapped according to spatial distribution of residual rubble crop (fig. 2). Small, scattered concentrations of biotite granite too small to map are present in rubble crop near the margins of the stock. The zinnwaldite granite unit apparently forms the core of the stock with apophyses extending into a partial shell of biotite-muscovite granite. Distribution of granitic units, coupled with geochemical and petrographic evidence discussed below, indicates that the three units represent a concentric alteration pattern that decreases in intensity toward the margins.

Differences in texture and grain size are subtle between the three granite units. The granite is generally composed of fine- to medium-grained (up to $8 \mathrm{~mm}$ ) quartz, alkali feldspar (perthite), plagioclase (albite) \pm biotite \pm muscovite \pm tourmaline, topaz, and garnet. Textures range from weakly porphyritic to weakly seriate hypidiomorphic in the biotite and biotite-muscovite granites. Zinnwaldite granite exhibits textures that range from graphic hypidiomorphic equigranular to microscale allotriomorphic seriate (fig. 3). In all three units, perthite and quartz exhibit bimodal size distribution, but size difference is generally less than a factor of 10 .

Perthite in biotite and biotite-muscovite granite units contain approximately 35-45 percent exsolved albite lamellae, whereas perthite in zinnwaldite granite contains approximately 5-15 percent albite lamellae. Plagioclase increases from 5-10 modal percent in biotite granite to 25-30 modal percent in zinnwaldite granite. Biotite in biotite granite is red brown and exhibits minor green alteration. Biotite in the biotite-muscovite granite is bleached, pale brown to brown gray in thin section and is commonly altered to white mica. White mica is usually associated with topaz and tourmaline and some white mica in the zinnwaldite granite is distinctly light gray brown and pleochroic. X-ray photoelectron spectroscopy (XPS) analysis indicates that the white mica is probably zinnwaldite (Burleigh, 1991).

Topaz is present $(<1$ percent $)$ in all granite units but is increasingly more abundant in biotite-muscovite and zinnwaldite granite units, respectively, as interstitial, anhedral, and rare, disseminated, euhedral grains. Tourmaline is a common interstitial mineral in biotitemuscovite granite and zinnwaldite granite.

I identified two types of dike rock at Sleitat Mountain. A third type, biotite-quartz porphyry, has been identified by a geologist of Cominco Alaska Exploration but was not observed or sampled during my investigations. Muscovite-quartz-feldspar porphyry and quartz-feldspar porphyry dikes strike east-northeast and are scattered over a distance of $5.6 \mathrm{~km}$ outward from the stock. Muscovitequartz-feldspar porphyry dikes are composed of about 35-40 percent 0.5- to 8.0-mm diam, anhedral-to-subhedral grains of alkali feldspar, quartz, muscovite, with lesser albite plagioclase in an aphanitic groundmass of feldspar, quartz, and muscovite (fig. 3). Muscovite-quartzfeldspar porphyry dikes represent altered counterparts of the quartz-feldspar porphyry dikes as indicated by microveinlets and patchy disseminations of muscovite and tourmaline, a coarsening of groundmass, and turbid alteration of feldspar phenocrysts.

\section{Deposit Morphology}

Tin mineralization is present at Sleitat Mountain in all types of granitic rock and in the enclosing hornfels. The bulk of the mineralization is confined to two zones composed of steeply dipping, tabular bodies of greisen alteration along the southern margin and in the northern part of the stock (fig. 2). Central quartz veinlets up to a few centimeters thick and often containing high concentrations (up to 50-60 percent) of fine- to coarse-grained cassiterite are the loci of greisen alteration in the tabular 


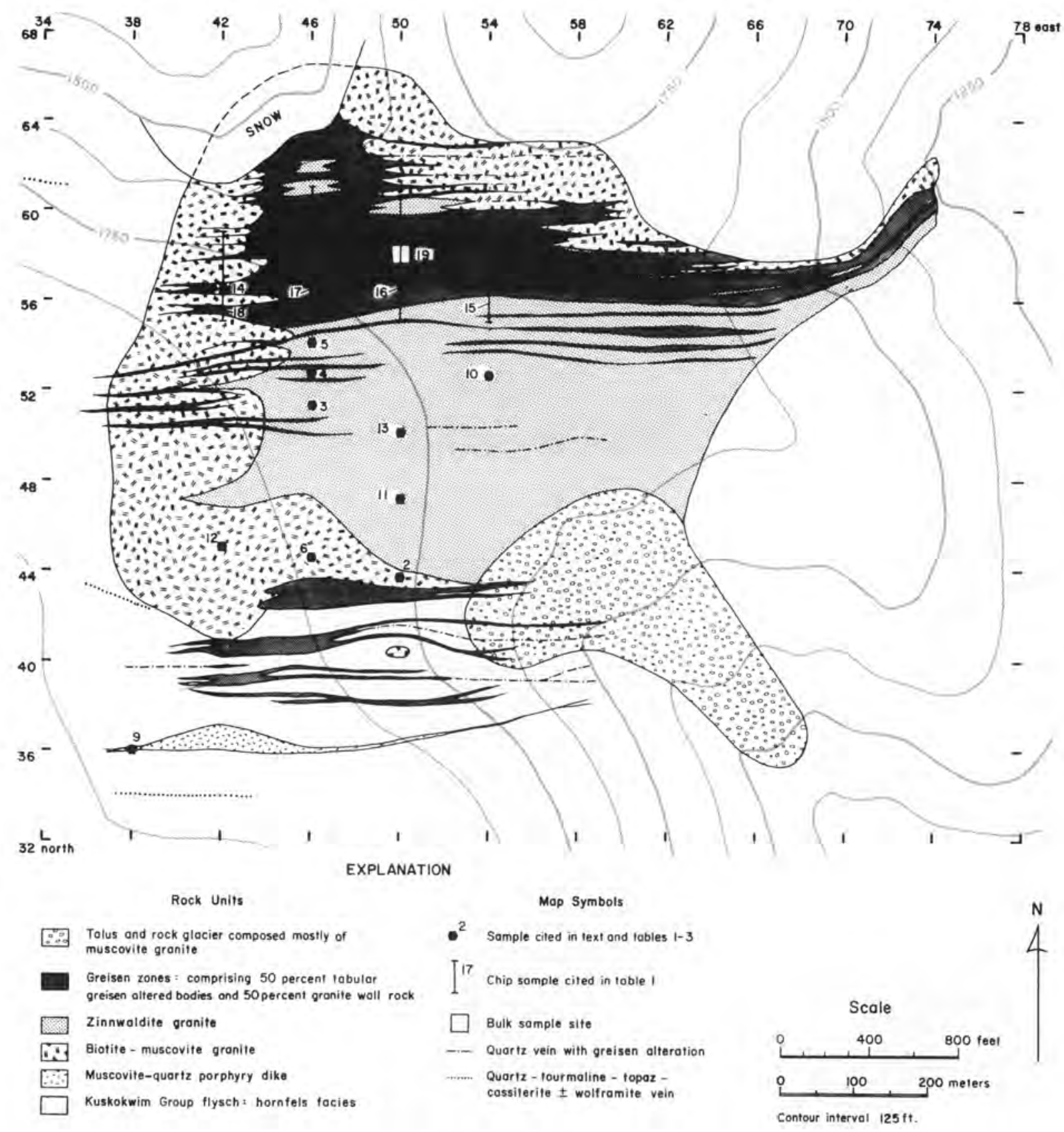

Figure 2. Geology and sample locations of compound granite stock and associated tin-tungsten greisen, Sleitat Mountain. Samples 1, 7, and 8 are located outside the above map area and can be located in Burleigh (1991, fig. 6).

bodies. Thicknesses of individual greisen masses range from several centimeters to $6 \mathrm{~m}$, and these masses are separated by zones of mildly altered to unaltered granites. Zones of greisen mineralization consist of about 50 percent greisen-altered granite interleaved with mildly altered to unaltered granite and extend for at least 975 $\mathrm{m}$ in length; their widths vary from 30 to $240 \mathrm{~m}$ (fig. 2). Greisen alteration is also a consequence of wolframitearsenopyrite veining. However, the dimensions and characteristics of greisen alteration associated with these veins are difficult to determine in rubble crop. 
In hornfels, coarse-grained quartz and rare quartztopaz veins crosscut sedimentary layers and fill tensional fractures and partings along bedding in metasedimentary rocks. These veins contain up to several percent fine- to coarse-grained cassiterite and minor amounts of wolframite. Discordant veins range in thickness up to $0.46 \mathrm{~m}$ and strike up to $60 \mathrm{~m}$ in rubble trains of vein material. Quartz-cassiterite veins that developed along tensional fractures were found only in scree accumulations, so their continuity and widths could not be established.

\section{Alteration}

A diversity of gangue- and ore-mineral suites is present in selected samples of mineralized rock. In tabular, steeply dipping greisen bodies that make up the bulk of the deposit, variable amounts of quartz, topaz, tourmaline, and white mica form a typical alteration assemblage. Concentrations of 10 to 15 percent topaz are not uncommon in the greisen, whereas tourmaline rarely exceeds 3 to 5 percent. Greisen-altered granite contains numerous scattered voids that may be relicts of incomplete replacement of feldspar and phyllosilicate minerals by alteration minerals. Most surface rubble is coated with iron oxide and lesser amounts of arsenic oxide (scorodite), indicating that sulfide minerals formerly occupied 1 to 5 percent of the rock. Oxidation and leaching of these sulfide minerals also contributed to the characteristically porous texture of the greisen.

\section{Ore Mineralogy}

Principal ore minerals include cassiterite, arsenopyrite, loellingite, sphalerite, and wolframite. Trace amounts of stannite, chalcopyrite, pyrite, bismite, bismuth-arsenic compounds, and ferrotantalite were also identified by scanning electron microscopy (SEM). Secondary hematite and arsenic oxides are widely distributed in weathered greisen samples.

Cassiterite is the primary ore mineral. Grains of disseminated cassiterite in massive greisen bodies are generally less than $1 \mathrm{~mm}$ in diameter. Medium- to coarse-grained cassiterite $(1-15 \mathrm{~mm})$ is present in high concentrations in narrow quartz veinlets within greisen

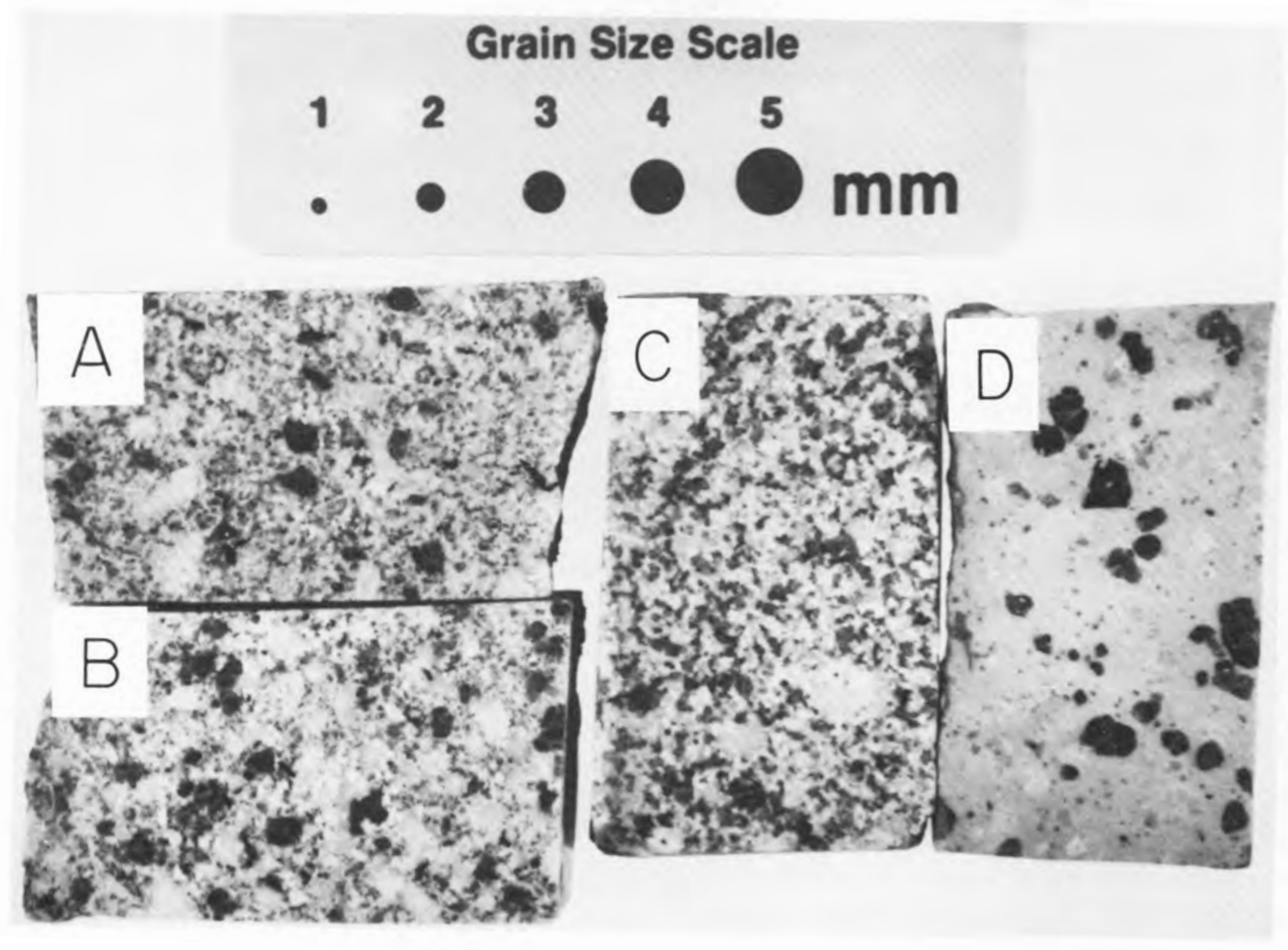

Figure 3. Photograph showing rock textures for (A) biotite granite, (B) biotite-muscovite granite, (C) zinnwaldite granite, and (D) feldspar-porphyry dike. 
masses and in hornfels. Open-space veinlets of coarse topaz with crystals of cassiterite and wolframite are rare in these rocks.

Wolframite is scattered throughout the deposit, mostly as medium-to-coarse (up to $2 \mathrm{~cm}$ ), tabular grains in massive-to-vuggy, coarse-grained quartz veins that are generally peripheral to greisen zones and in the hornfels. These veins attain widths up to $0.6 \mathrm{~m}$ and apparently represent a distinct mineralizing pulse. Fine-grained wolframite is also present as a trace constituent in tinrich, massive greisen.

Arsenic minerals are distributed throughout the deposit. Clots of arsenopyrite (up to $2.5 \mathrm{~cm}$ ) are common in coarse-grained, quartz-white mica-wolframite veins. Locally, relatively unaltered and foliated biotitemuscovite granite contains about 5 percent disseminated loellingite $\left(\mathrm{FeAs}_{2}\right)$ in association with minute amounts of arsenopyrite and inclusions of bismite (bismuth oxide). However, disseminated arsenopyrite is the primary arsenic mineral and is present in concentrations up to 5 percent in greisen-altered granitic rocks in the absence of loellingite. Micron-sized inclusions of bismite and a bismuth-arsenic mineral were identified in the arsenopyrite by SEM analysis.

Sphalerite is rare; however, a few specimens were found to contain up to 0.5 percent sphalerite as disseminated grains. Sphalerite contains micron-sized inclusions of bornite, chalcopyrite, and stannite. Coarser grains (approximately $400 \mu \mathrm{m}$ ) of stannite adjoin grain boundaries of sphalerite and are present as disseminated grains in these zinc-rich samples. A single, 30- $\mu \mathrm{m}$ grain of ferrotantalite was identified in greisen-altered granite during SEM analysis.

\section{GEOCHEMISTRY}

\section{Geochemistry of Mineralized Rocks}

A limited sampling program was conducted to determine a tin-resource estimate for the deposit (Burleigh, 1991). The tin grade of greisen and granite and the density of greisen bodies in the north zone were estimated by taking four, 122- to 183-m-long chip samples across the rubble. Sample chips were collected at 0.9-m intervals and sorted into a composite granite and a composite greisen sample per line (fig. 2). Analytical results from this sampling program are presented in table 1, and a tin-resource estimate is discussed by Burleigh (1991).

The first three samples (15-17) in table 1 represent the center of the northern greisen zone; tin, tungsten, and silver are uniformly distributed in these granite and greisen samples. However, the fourth sample in table 1 demonstrates thinning of greisen veins at the western edge of the northern greisen zone, where the greisen:granite ratio is lower. In this westernmost sample site, thin (mmscale) cassiterite-bearing veinlets are present in some granite chips, which accounts for higher tin values than in greisen samples. As a rule, I avoided obviously highgrade, coarse-grained cassiterite veinlets during sampling of the massive greisen-altered granite to eliminate nugget effects. Therefore, tin concentration in these samples is underestimated.

A 816-kg bulk sample collected from the center of the northern greisen zone assayed $3,700 \mathrm{ppm}$ tin $(0.37$ percent $\mathrm{Sn}$ ) (table 2), which probably better represents the grade of the deposit than the four chip samples. Amulti-element analysis of the bulk sample documents only minor baseand rare-metal concentrations (table 2). Information provided by H.E. Farnstrom (written commun., 1990) indicates that at least one drill hole at Sleitat Mountain intersected $14.54 \mathrm{~m}$ (true width) of 1.56 percent tin and

Table 1. Analytical data for chip samples located in figure 2

\begin{tabular}{|c|c|c|c|c|c|c|c|}
\hline Sample & $\begin{array}{l}\text { Rock } \\
\text { type }\end{array}$ & $\begin{array}{l}\text { Number } \\
\text { of chips }\end{array}$ & $\begin{array}{c}\mathrm{Sn} \\
\mathrm{ppm}\end{array}$ & $\begin{array}{c}\mathrm{W} \\
\mathrm{ppm}\end{array}$ & $\begin{array}{c}\mathrm{Ag} \\
\mathrm{ppm}\end{array}$ & $\begin{array}{c}\mathrm{Nb} \\
\mathrm{ppm}\end{array}$ & $\begin{array}{c}\mathrm{Ta} \\
\mathrm{ppm}\end{array}$ \\
\hline \multirow[t]{2}{*}{15} & Greisen & 83 & 1,900 & 150 & 16.7 & 23 & $<3$ \\
\hline & Granite & 84 & 120 & 45 & 0.7 & 26 & $<3$ \\
\hline \multirow[t]{2}{*}{16} & Greisen & 82 & 2,900 & 110 & 13.1 & 30 & $<3$ \\
\hline & Granite & 69 & 75 & 45 & 1.0 & 32 & 9 \\
\hline \multirow[t]{2}{*}{17} & Greisen & 99 & 3,100 & 110 & 11.2 & 18 & 12 \\
\hline & Granite & 96 & 930 & 45 & 2.5 & 26 & $<3$ \\
\hline \multirow[t]{2}{*}{18} & Greisen & 52 & 880 & 150 & 7.0 & 33 & $<3$ \\
\hline & Granite & 85 & 2,100 & 900 & 7.4 & 24 & 9 \\
\hline
\end{tabular}


Table 2. Multi-element analysis of the 816-kg greisen bulk sample located at map location 20, figure 2

$$
\begin{aligned}
\mathrm{Ag} & =17 \mathrm{ppm} \\
\mathrm{As} & =3,480 \mathrm{ppm} \\
\mathrm{Au} & =19 \mathrm{ppb} \\
\mathrm{Bi} & =32 \mathrm{ppm} \\
\mathrm{Cd} & =<57 \mathrm{ppm} \\
\mathrm{Ce} & =16 \mathrm{ppm} \\
\mathrm{Co} & =<10 \mathrm{ppm} \\
\mathrm{Cs} & =7 \mathrm{ppm}
\end{aligned}
$$

$\mathrm{Rb}=90 \mathrm{ppm}$
$\mathrm{Sb}=382 \mathrm{ppm}$
$\mathrm{Sc}=4.8 \mathrm{ppm}$
$\mathrm{Se}=<10 \mathrm{ppm}$
$\mathrm{Sm}=2.4 \mathrm{ppm}$
$\mathrm{Sn}=3,700 \mathrm{ppm}$
$\mathrm{Ta}=8 \mathrm{ppm}$
$\mathrm{Tb}=<1 \mathrm{ppm}$

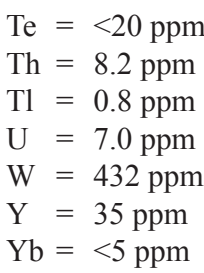

$\mathrm{Te}=<20 \mathrm{ppm}$

$\mathrm{Th}=8.2 \mathrm{ppm}$

$\mathrm{Tl}=0.8 \mathrm{ppm}$

$\mathrm{U}=7.0 \mathrm{ppm}$

$\mathrm{Y}=35 \mathrm{ppm}$

$\mathrm{Yb}=<5 \mathrm{ppm}$
$0.81 \mathrm{oz} /$ tonne silver; this interval includes an interval of $1.54 \mathrm{~m}$ (true width) that grades 12.55 percent tin and 5.17 oz/tonne silver. Drilling by Cominco Alaska Exploration has confirmed appreciable tin mineralization to a vertical depth of $91.4 \mathrm{~m}$ and has yet to encounter the base of the mineralized system (H.E. Farnstrom, written commun., 1990).

\section{Major-Element Geochemistry of Granitic Rocks}

Spatial and temporal relations of granitic units at Sleitat Mountain cannot be adequately established due to lack of outcrop. Selected plots of whole-rock major elements (fig. 4a-e) define trends in major-element compositions interpreted to represent alteration of a fractionated granite by late-stage hydrothermal fluids. These plots document systematic increases of $\mathrm{Na}_{2} \mathrm{O}, \mathrm{Al}_{2} \mathrm{O}_{3}$, and peraluminous index (molecular $\mathrm{Al}_{2} \mathrm{O}_{3} / \mathrm{Na}_{2} \mathrm{O}+\mathrm{CaO}+\mathrm{K}_{2} \mathrm{O}$ $>1$ is peraluminous) and concomitant decreases of $\mathrm{SiO}_{2}$, $\mathrm{K}_{2} \mathrm{O}, \mathrm{CaO}$, and $\mathrm{TiO}_{2}$ from marginal biotite granite to core zinnwaldite granite. These variations can be attributed to an increase in alteration intensity from the margin to the core of the stock. A variation diagram of ferrous and ferric iron oxides (fig. 4f) provides evidence for the moderately low oxidation state of the magma from which the granite crystallized. Results of major- and trace-element analyses are listed in table 3 .

Depletion of $\mathrm{TiO}_{2}$ can be linked to alteration of biotite and depletion of $\mathrm{CaO}$ and $\mathrm{K}_{2} \mathrm{O}$ (fig. 4b-c), probably by albitization ( $\mathrm{Na}_{2} \mathrm{O}$-enrichment) of the stock core. Silica depletion (fig. 4b) in the core probably resulted from removal of $\mathrm{SiO}_{2}$ by late-stage fractionation of a vapor phase that produced extensive greisen alteration. Enrichment of $\mathrm{Al}_{2} \mathrm{O}_{3}$ (fig. $4 \mathrm{e}$ ) can be attributed to alteration of feldspars to white mica and the increasing presence of topaz from the margin to the core of the stock.

Hudson and Arth (1983) concluded that a positive correlation between $\mathrm{Na}_{2} \mathrm{O}$ and Differentiation Index (DI) (Thorton and Tuttle, 1960) in the most differentiated (fine-grained equigranular) phases of Seward Peninsula tin-granites represents an evolutionary trend in crystallization. They suggested that development of this "albite trend" is evidence for vapor-phase saturation of the melt during crystallization. Plots of weight percent $\mathrm{Na}_{2} \mathrm{O}$ versus DI for Sleitat Mountain granites (fig. 4a) indicate a progressive increase in $\mathrm{Na}_{2} \mathrm{O}$ but only weakly define an albite trend relative to DI. This increase in $\mathrm{Na}_{2} \mathrm{O}$ coincides with increasing albite in the granite core.

In terms of $\mathrm{Al}_{2} \mathrm{O}_{3}, \mathrm{SiO}_{2}, \mathrm{Na}_{2} \mathrm{O}$, and $\mathrm{K}_{2} \mathrm{O}$ and based on data from Tischendorf (1977), the Sleitat Mountain granite is geochemically similar to the average tin-granite. Plots of $\mathrm{Na}_{2} \mathrm{O}$ versus DI (fig. $4 \mathrm{a}$ ) indicate that the Sleitat Mountain granite is slightly more evolved than the average tin-granite.

\section{Trace-Element Geochemistry of The Granitic Rocks}

Although trace-element analyses for lithium, fluorine, and boron were not obtained for Sleitat Mountain granites, increases in the amounts of tourmaline (containing boron) and topaz (containing fluorine) in biotite-muscovite granite and zinnwaldite granite indicate increasing boron and fluorine with progressive alteration, as noted in tin-granites elsewhere (Swanson and others, 1988; Manning and Hill, 1990). The typical pattern of trace-element distribution from biotite granite to zinnwaldite granite in the Sleitat Mountain stock is decreasing barium and strontium and increasing rubidium (table 3 , samples 5, 13, 14). These trends are consistent with fractional-crystallization models demonstrated by McCarthy and Hasty (1976). However, the enrichment of rubidium and depletion of barium and strontium are probably responses to the alteration of feldspars to white mica and to albitization.

Zirconium, niobium, cerium, and yttrium are useful indicators of magmatic trends because they are generally insensitive to hydrothermal alteration (Alderton and others, 1980). However, plots of gallium versus rubidium, zirconium, niobium, and yttrium in the Sleitat Mountain granite (figs. 5a-e) exhibit trends that can be interpreted to represent a single melt fraction that was systematically 


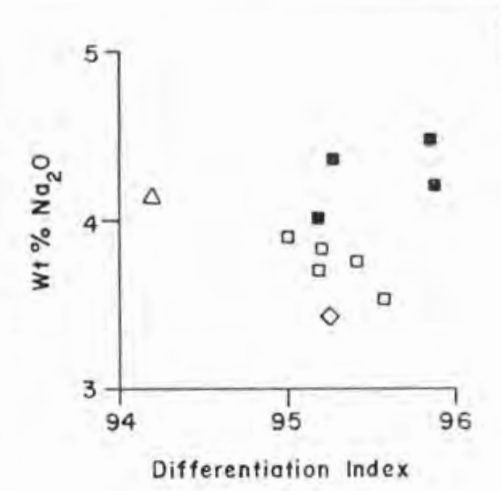

A

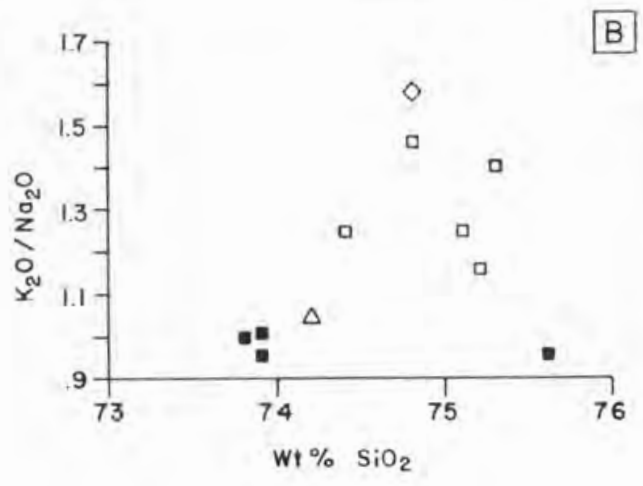

B

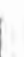




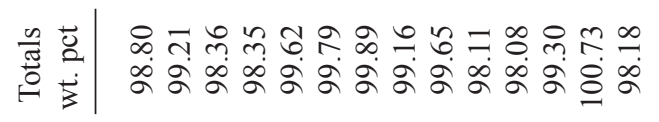

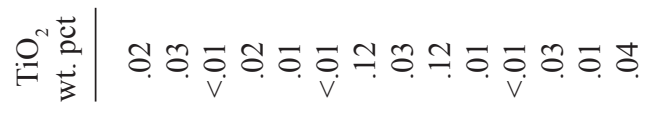

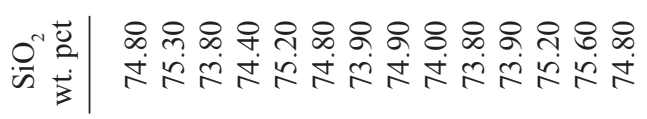

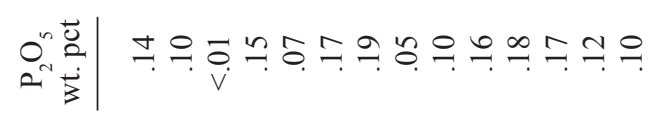

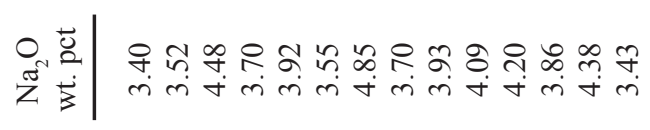

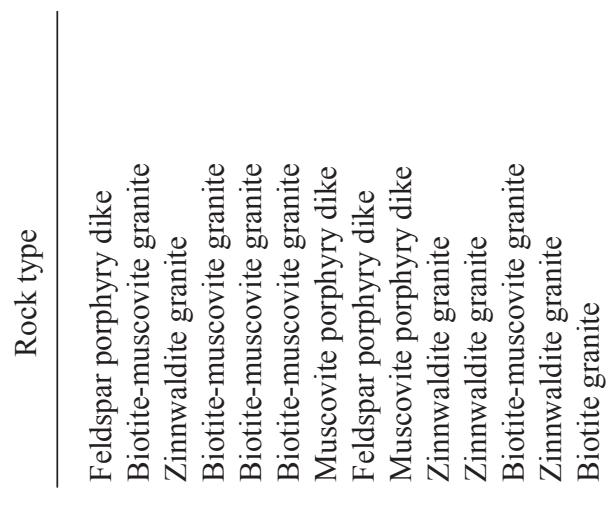

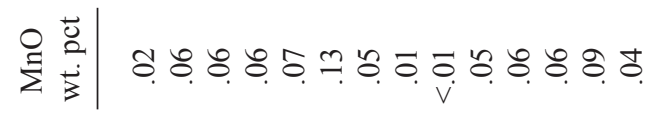

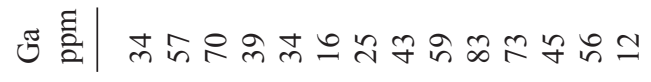

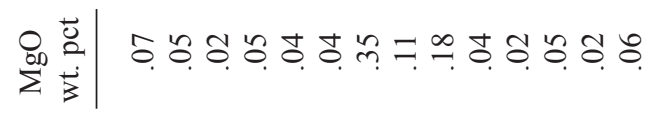

ن 혈|

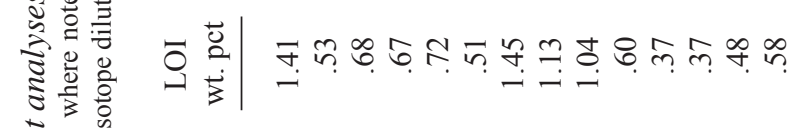

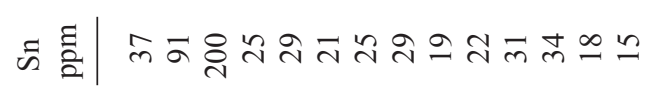

入言|

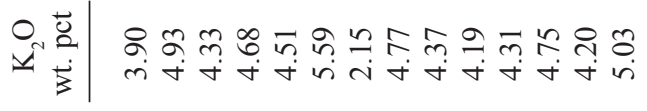

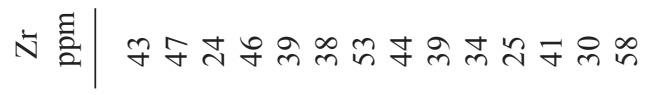

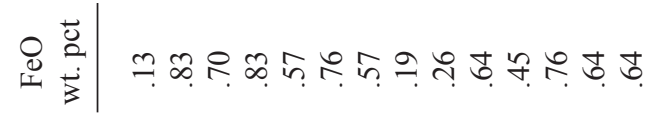

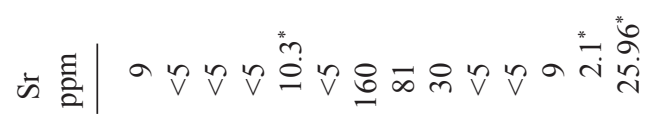

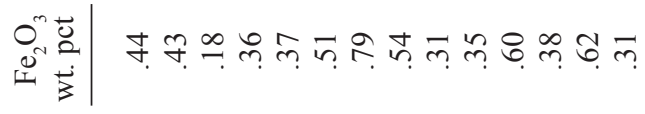

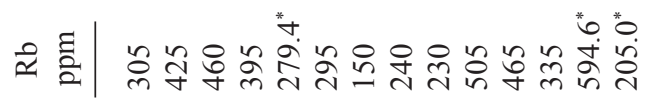

导落| ๆ

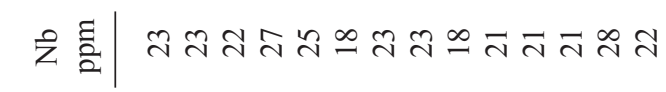

जิ

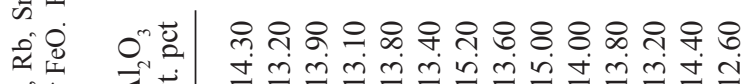

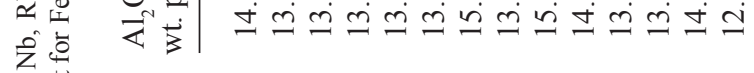

๓ீ 苍

苍

咅|

๓̃ 窇| 
altered from the core to the margins. Gallium remains mobile in a melt as a $\left(\mathrm{GaF}_{6}\right)^{-3}$ complex in fluorine-rich magmas (Collins and others, 1980). Gallium also tends to concentrate in plagioclase, substituting for aluminum, and is preferentially excluded from An-rich plagioclase (Collins and others, 1980). Therefore, gallium enrichment may be a function of the crystallization of topaz and albite in the stock core. Zirconium and, to a lesser extent, yttrium exhibit depletion trends from stock margin to core (figs. 5a-b). Alderton and others (1980) observed strong depletions of zirconium in similar granitic rocks as a result of tourmalinization and kaolinization and attributed these losses to the destruction of zircon during replacement of biotite by tourmaline. Hill and Manning (1987) observed that inclusion-free "brown" mica (bleached biotite at Sleitat Mountain) in a topaz granite was

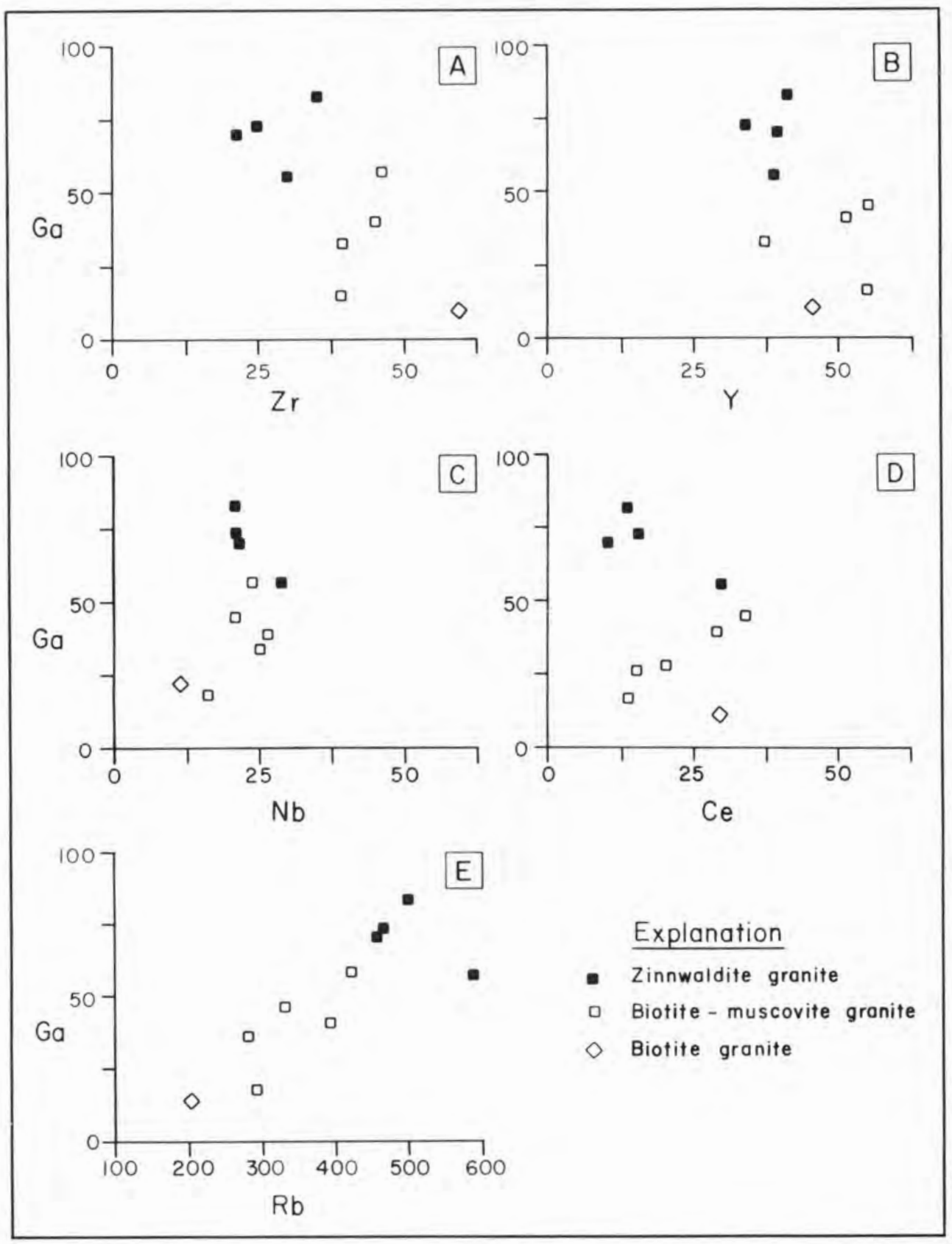

Figure 5. Trace-element variation diagram comparing three granites at Sleitat Mountain. Analytical data on which these plots are based are listed in table 3. 
derived by alteration of zircon-bearing biotite. Increased tourmalinization and formation of bleached biotite and zinnwaldite in core granites of the Sleitat Mountain stock also indicate zirconium depletion resulted from alteration and is not a function of melt fractionation.

Yttrium exhibits a similar but weaker depletion trend (fig. 5b), implying mobilization in response to hydrothermal alteration. Niobium exhibits no enrichment or depletion trends in the granitic units (fig. 5c) or greisenaltered rocks, indicating that niobium is immobile during progressive greisen alteration. Clustering of niobium values also indicates that magmatic fractionation had little, if any, role in zonation of the stock.

In general, cerium is weakly depleted in the direction of biotite biotite-muscovite zinnwaldite granites (fig. 5d). In late-stage, equigranular fractions of tin-granites on Seward Peninsula, Hudson and Arth (1983) observed a cerium gradient and suggested that cerium is depleted along with other volatiles during late stages of crystallization.

\section{DISCUSSION}

Concentration of tin in late-magmatic differentiates and in magmatic fluids is attributed by Lehmann (1982) to a low oxidation state in the melt. However, Swanson and others (1988) emphasized that a given bulk melt composition that prevents formation of such tin-concentrating minerals as sphene, hornblende, and iron-titanium oxides effectively retains tin in residual melts during fractional crystallization. These conditions must prevail in less evolved melt fractions of granites in a tin system (for example, the porphyritic and seriate phases of Swanson and others, 1988). However, one can only surmise the presence of a less fractionated phase at depth because these granites are not exposed at Sleitat Mountain. Further, there is no evidence to indicate the presence of an associated plutonic complex at depth, so other explanations for the origin of topaz granites like Sleitat Mountain merit consideration.

Manning and Hill (1990) proposed a model in which refractory residues of previously generated biotitegranite magmas are partially melted in the lower crust to form a volatile-rich, specialized magma that then intrudes upper crustal rocks. This model eliminates the formation of "topaz-granite" magma as a generative process during magmatic differentiation but requires spatially associated magmatic rocks. Although the Sleitat Mountain stock could have intruded through a deeper batholithic complex, known geologic evidence does not support this association.

\section{CONCLUSION}

The presence of a significant tin-mineralized granite in an area generally devoid of magmatic rocks invites speculation about the economic potential of the region. Sleitat Mountain stock is a multi-unit, highly differentiated, peraluminous, altered granite. This specialized granite has major- and trace-element characteristics that imply emplacement was followed by an alteration event that progressed and diminished in intensity from the core toward the margins of the stock. Granite alteration was presumably produced by a hydrothermal fluid that was fractionated from the magma. Extensive greisen alteration developed in the crystalline granite along an east-striking fracture system and overprinted the zonal alteration facies. From an economic standpoint, it is essential to recognize that mineralization and greisen alteration produced vertical, tabular greisen bodies plumbed by fluid channels now occupied by quartz-cassiterite veinlets. Mineralization may extend to significant depths below the drill-tested (91-m) mineralized horizons.

In the Kuskokwim Mountains and the Alaska Range, Wallace and Engebretson (1984) identified northeaststriking magmatic belts that bound a central area containing few intrusive rock units. Significant tin geochemical anomalies (King and others, 1985) and coincident aeromagnetic signatures (Case and Nelson, 1986) along the Mulchatna fault northeast of Sleitat Mountain indicate that other poorly or unexposed intrusive bodies exist in that area. This evidence and the presence of the tin-granite at Sleitat Mountain imply that there is a continuum between the magmatic belts of the Kuskokwim Mountains and Alaska Range. This intermediate region may be a viable target for other tin-mineralized systems like Sleitat Mountain. The particular geochemical characteristics of the Sleitat Mountain stock compare closely with other tin-producing granite complexes of the world.

\section{ACKNOWLEDGMENTS}

I thank Helen Farnstrom, Project Geologist, Cominco Alaska Exploration, Inc., for the opportunity to visit and study mineralization at their Sleitat Mountain mining claims. Manuscript reviews by Rainer J. Newberry (University of Alaska Fairbanks) and Diana N. Solie (DGGS) contributed greatly to my interpretation of data presented in this report. 


\section{REFERENCES}

Alderton, D.H.A., Pearce, J.A., and Potts, J.A., 1980, Rare earth element mobility during granite alteration: Evidence from south-west England: Earth and Planetary Science Letters, v. 40, p. 149-165.

Burleigh, R.E., 1991, Evaluation of the tin-tungsten greisen mineralization and associated granite at Sleitat Mountain, southwest Alaska. U.S. Bureau of Mines Open-file Report 35-91, 41 p.

Case, J.E., and Nelson, W.H., 1986, Maps showing aeromagnetic survey and geologic interpretation of the Lake Clark Quadrangle, Alaska: U.S. Geological Survey Miscellaneous Field Studies Map MF-1114E, scale 1:250,000, 2 sheets.

Collins, W.J., Beams, S.D., White, A.J.R. and Chappell, B.W., 1980, Nature and origin of A-type granites with particular reference to southeastern Australia: Contributions to Mineralogy and Petrology, v. 80, p. 189-200.

Hill, P.I., and Manning, D.A.C., 1987, Multiple intrusions and pervasive hydrothermal alteration in the St. Austell Granite, Cornwall: Proceedings of the Ussher Society 6, p. 447-453.

Hudson, Travis, and Arth, J.G., 1983, Tin granites of Seward Peninsula, Alaska: Geological Society of America Bulletin, v. 94, no. 6, p. 768-790.

King, H.D., Tripp, R.B., Cooley, E.F., and Crim, W.D., 1985, Maps showing the distribution and abundance of selected elements in two geochemical sampling media, Lake Clark quadrangle, Alaska: U.S. Geological Survey Miscellaneous Field Studies Map MF-1114C, scale 1:250,000, 4 sheets.
Lehmann, Bernd, 1982, Metallogeny of tin: Magmatic differentiation versus geochemical heritage: Economic Geology, v. 77, no. 1, p. 50-59.

Manning, D.A.C., and Hill, P.I., 1990, The petrogenetic and metallogenetic significance of topaz granite from the southwest England orefield, in Stein, H.J., and Hannah, J.L., eds., Ore-bearing granite systems: Petrogenesis and Mineralizing Processes: Geological Society of America Special Paper 246, p. 51-69.

McCarthy, T.S., and Hasty, R.A., 1976, Trace element distribution patterns and their relationship to the crystallization of granitic melts: Geochimica et Cosmochimica Acta, v. 40, no. 11, p. 1351-1358.

Swanson, S.E., Bond, J.F., and Newberry, R.J., 1988, Petrogenesis of the Ear Mountain tin granite, Seward Peninsula, Alaska: Economic Geology, v. 83., no. 1, p. 46-61.

Tischendorf, G., 1977, Geochemical and petrographic characteristics of silicic magmatic rocks associated with rare-element mineralization, in Stemprok M., Burnol, B., and Tischendorf, G., eds., Metallization associated with acid magmatism: Prague, Czechoslovakia Geological Survey, Symposium Proceedings, v. 2, p. 41-96.

Thorton, C.P., and Tuttle, O.F., 1960, Chemistry of igneous rocks, I. Differentiation index: American Journal of Science, v. 258, no. 9, p. 664-684.

Wallace, W.K. and Engebretson, D.C., 1984, Relationships between plate motion and Late Cretaceous to Paleogene magmatism in southwestern Alaska: Tectonics, v. 3., no. 2, p. 295-315. 



\title{
NATIVE MERCURIAN-SILVER, SILVER, AND GOLD NUGGETS FROM HUNTER CREEK, ALASKA
}

\author{
By
}

Robert B. Forbes ${ }^{1}$ and Bart Cannon ${ }^{2}$

\section{INTRODUCTION}

Three silver-gray nuggets and a gold nugget recovered from placer-mining concentrates on Hunter Creek, Alaska, were submitted for identification to the authors by Steve Losonsky, longtime miner in the Rampart district, Alaska (fig. 1).

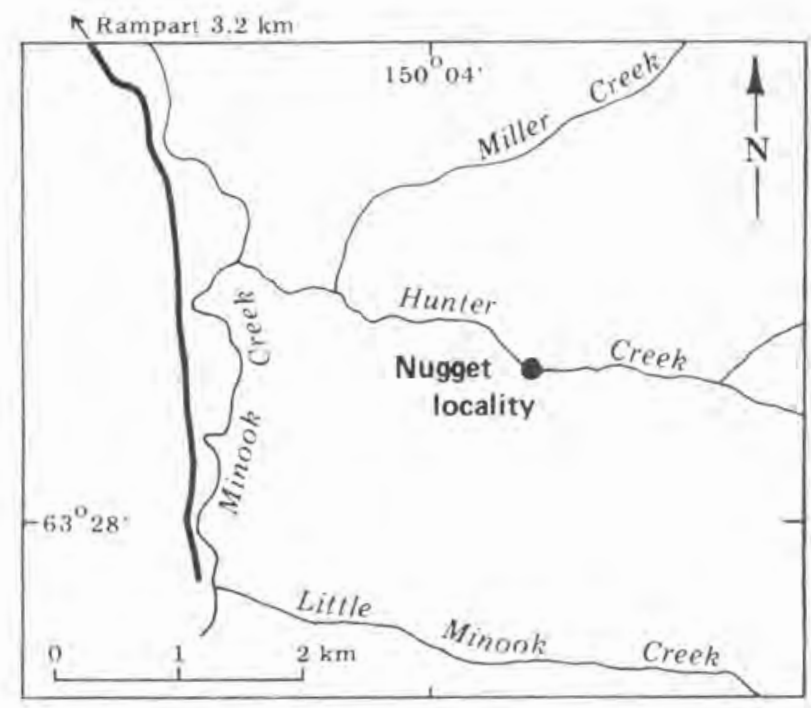

Figure 1. Sketch map of northeastern corner of Tanana B-1 Quadrangle showing nugget collection locality on Hunter Creek.

The analyzed nuggets were among several collected by Mr. Losonsky, along with other heavy minerals, including cinnabar, from the same placer concentrates.

\section{DESCRIPTIVE MINERALOGY}

Three of the specimens (nuggets \#1-3) have a dullgray, metallic luster and the characteristic irregular form of well-travelled placer nuggets, including rounded and pitted surfaces (fig. 2). Initially, these three nuggets were

${ }^{1}$ Former address: Alaska Division of Geological \& Geophysical Surveys, 794 University Avenue, Suite 200, Fairbanks, Alaska 99709-3645. Present address: Lincoln Beach No. 4, Port Townsend, Washington 98368.

${ }^{2}$ Cannon Microprobe/SEM Laboratory, Seattle, Washington.

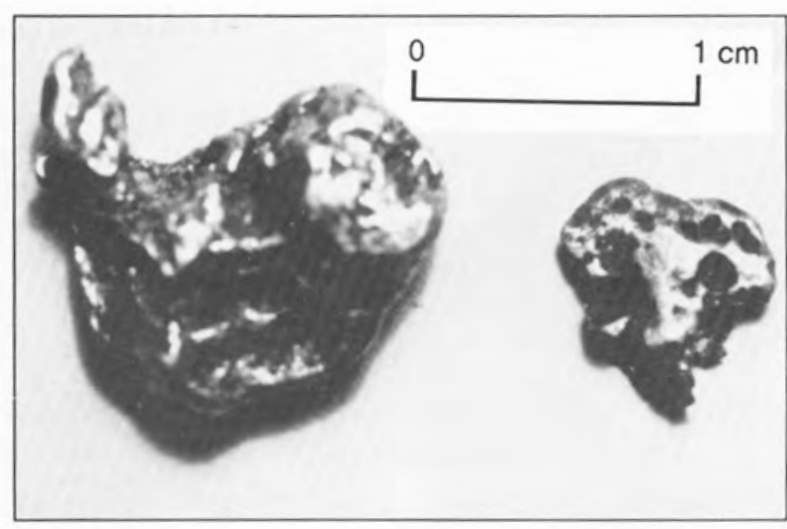

Figure 2. Morphology of mercurian-silver nuggets \#1 (left) and \#2 (right) from Hunter Creek.

thought to be native silver or platinum, but specific-gravity determinations were too low, and preliminary hardness tests indicated that the nuggets were softer and more malleable than either native silver or typical platinumpalladium alloys.

Because of their small size and scarcity, the specimens were chemically analyzed using nondestructive methods (microprobing and X-ray diffraction).

\section{MICROPROBE ANALYSES}

\section{Surface Analyses}

Exploratory probe analyses involved using an ARL Model SEMQ electron microprobe operated at $25 \mathrm{kV}$ and $50 \mathrm{nA}$ amp beam currents on unprepared nugget surfaces prior to the preparation of polished surfaces for more precise analyses. These exploratory analyses detected small irregular areas of gold-silver-mercury composition in a matrix of silver-mercury on the surfaces of nuggets $\# 1$ and \#2 (fig. 3). Initially, raw assay data indicated the presence of moschellandsbergite (silver-mercury) in the matrix and irregular patches of weishanite (silvergold-mercury). However, both minerals are crystalline, relatively brittle, and are characterized by well-defined cleavage, properties not present in analyzed phases in the nuggets. 


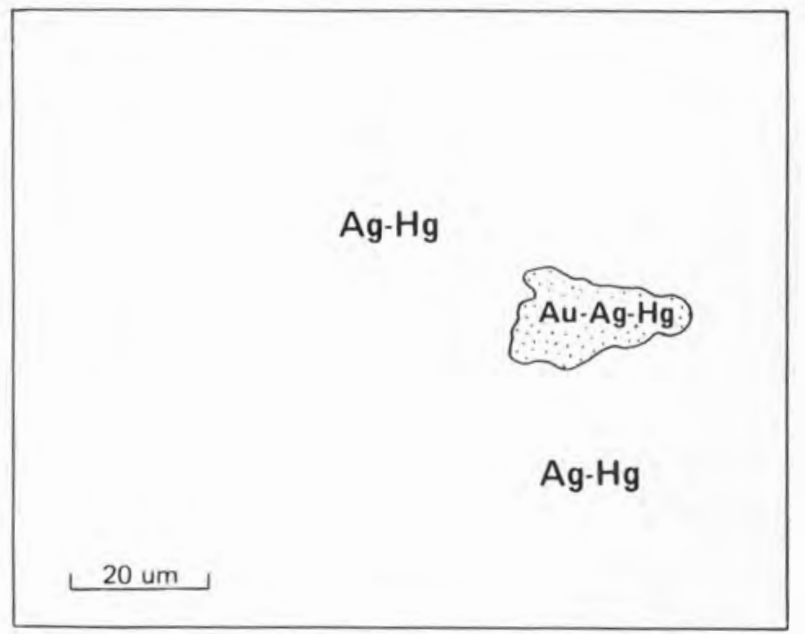

Figure 3. Sketch of photomicrograph ofunpolished surface of nugget \#1 showing irregular area of silver-goldmercury (5 to 6 percent gold) surrounded by matrix of mercurian silver ranging in composition from $\mathrm{Ag}_{45}-\mathrm{Hg}_{55}$ to $\mathrm{Ag}_{65}-\mathrm{Hg}_{35}$.

\section{Polished Surface Analyses}

Electron-microprobe analyses of polished surfaces produced the data summarized in table 1 . These data show that the matrices of nuggets \#1 and \#2 are composed of silver-mercury alloy, and that the gold-silver-mercury compositions are confined to small, irregular areas on unpolished surfaces of the nuggets (fig. 3). The evidence indicates that patchy concentrations of gold-silver-mercury surrounded by silver-mercury alloy may be the result of amalgamation of fine placer gold with silver-mercury on nugget surfaces in the fluvial environment.

In contrast, electron microprobing and X-ray diffraction demonstrate that nugget \#3 is composed of native silver, and it has a mercury content of only 0.2 weight percent (table 1).

A gold nugget believed to be typical of coarse gold recovered from the placer gravels of Hunter Creek was analyzed for gold, silver, mercury, and copper to determine if native gold associated with cinnabar and mercurian silver in placer concentrates also carries a significant mercury content. Probe analyses indicate that the native gold has a fineness of about 0.850 and a low mercury content ( 0.11 weight percent) (table 2$)$.

\section{Other Mineral Phases}

Microprobing also identified accessory minerals. Nugget \#1 contains many 20 - to $70-\mu \mathrm{m}$-diam inclusions of crystalline quartz, cinnabar (fig. 3), and inclusions of a
Table 1. Percent compositions of silver-mercury and silver nuggets based on electron microprobing

\begin{tabular}{|c|c|c|c|}
\hline Element & $\begin{array}{c}\text { Nugget } \\
\# 1\end{array}$ & $\begin{array}{c}\text { Nugget } \\
\# 2 \\
\end{array}$ & $\begin{array}{c}\text { Nugget } \\
\# 3 \\
\end{array}$ \\
\hline $\mathrm{Ag}$ & 59.5 & 53.1 & $>90.0^{\mathrm{a}}$ \\
\hline $\mathrm{Hg}$ & 38.2 & 45.4 & 0.2 \\
\hline $\mathrm{Au}$ & nd & nd & nd \\
\hline $\mathrm{Cu}$ & 0.1 & 0.2 & nd \\
\hline $\mathrm{Fe}$ & nd & nd & nd \\
\hline $\mathrm{Zn}$ & 0.2 & 0.2 & nd \\
\hline $\mathrm{Sb}$ & nd & 0.1 & nd \\
\hline $\mathrm{Te}$ & nd & nd & nd \\
\hline $\mathrm{Pb}$ & $\operatorname{tr}$ & nd & nd \\
\hline As & nd & 0.1 & nd \\
\hline $\mathrm{Sn}$ & 0.1 & nd & nd \\
\hline $\mathrm{Bi}$ & nd & nd & nd \\
\hline Se & nd & nd & nd \\
\hline Total & $\overline{98.1}$ & 99.1 & $\overline{90.2}$ \\
\hline
\end{tabular}

${ }^{a}$ High percentage of silver masked all of these elements but mercury. nd $=$ not detected

Table 2. Percent composition of gold nugget based on an electron microprobing

$\begin{array}{lr}\text { Element } & \text { Weight percent } \\ & \\ \mathrm{Au} & 85.10 \\ \mathrm{Ag} & 14.40 \\ \mathrm{Hg} & 0.11 \\ \mathrm{Cu} & \text { nd } \\ \text { Total } & 99.61 \\ & \end{array}$

silver-mercury sulfide similar in composition to imiterite (table 3). Nugget \#2 contains grains of euhedral quartz, imiterite (table 3) (fig. 4), and less abundant acanthite. Nugget \#3 has abundant inclusions of dyscrasite.

\section{COEXISTING MINERAL ASSEMBLAGES AND POSSIBLE SOURCE TERRANES}

Thus, a unique assemblage of coexisting minerals is documented for the dull-gray nuggets in the Hunter Creek collection (table 4). These coexisting mineral phases and abundant cinnabar grains and pebbles in the placer concentrates present a convincing case for 
Table 3. Percent compositions of mineral inclusions in mercury-silver nuggets based on electron microprobing

\begin{tabular}{|c|c|c|c|}
\hline Element & $\begin{array}{l}\text { Unidentified } \\
\text { red mineral } \\
\text { (nugget \#1) }\end{array}$ & \multicolumn{2}{|c|}{$\begin{array}{c}\text { Imiterite } \\
\text { ( nugget \#2) }\end{array}$} \\
\hline $\mathrm{Ag}$ & 29.0 & 44.6 & 45.3 \\
\hline $\mathrm{Hg}$ & 55.0 & 41.9 & 42.7 \\
\hline S & 14.0 & 13.4 & 12.1 \\
\hline Total & $\overline{98.0}$ & $\overline{99.9}$ & $\overline{100.1}$ \\
\hline
\end{tabular}

a possible source terrane in the headwaters of Hunter Creek that contains silver-mercury- and silver-antimonydominated epithermal mineral deposits. However, based on the relatively low mercury content of the analyzed gold nugget and the lack of detectable occult gold in the mercurian-silver nuggets, there is no direct evidence to indicate that placer gold in Hunter Creek was derived from an epithermal silver-mercury-dominated mineral deposit. Possibly the native silver nugget with dycrasite inclusions was derived from a supergene deposit that is unrelated to the silver-mercury system that produced the native silver-mercury alloys and the coexisting silvermercury and silver-mercury-sulfur mineral phases.

\section{EPITHERMAL ANALOGUES AND MODELS}

Table 4. Mineralogy of three mercurian-silver and silver nuggets from Hunter Creek.

\begin{tabular}{|c|c|c|}
\hline Nugget & Mineral & Composition \\
\hline$\# 1$ & $\begin{array}{l}\text { Mercurian silver } \\
\text { Imiterite } \\
\text { Cinnabar } \\
\text { Quartz }\end{array}$ & $\begin{array}{l}\mathrm{Ag}_{59} \mathrm{Hg}_{38}{ }^{\mathrm{a}} \\
\mathrm{Ag}_{2} \mathrm{HgS}_{2} \\
\mathrm{HgS} \\
\mathrm{SiO}_{2}\end{array}$ \\
\hline$\# 2$ & $\begin{array}{l}\text { Mercurian silver } \\
\text { Imiterite } \\
\text { Acanthite } \\
\text { Quartz }\end{array}$ & $\begin{array}{l}\mathrm{Ag}_{53} \mathrm{Hg}_{45} \\
\mathrm{Ag}_{2} \mathrm{HgS}_{2} \\
\mathrm{Ag}_{2} \mathrm{~S} \\
\mathrm{SiO}_{2}\end{array}$ \\
\hline$\# 3$ & $\begin{array}{l}\text { Native silver } \\
\text { Dyscrasite }\end{array}$ & $\begin{array}{l}\mathrm{Ag}(\text { trace } \mathrm{Hg}) \\
\mathrm{Ag}_{3} \mathrm{Sb}\end{array}$ \\
\hline
\end{tabular}

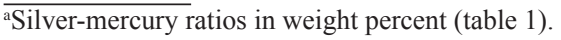

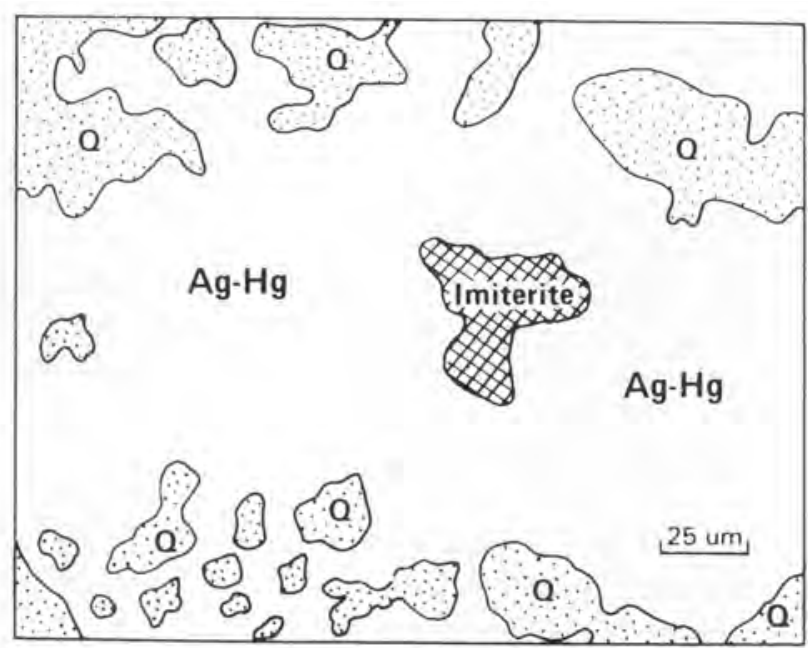

Figure 4. Sketch of photomicrograph of polished surface of nugget \#1 showing imiterite and quartz (Q) inclusions.

A search of the literature has not produced a recognized analogue for an epithermal mineral deposit that contains the silver-mercury-sulfur minerals and native alloys identified in the Hunter Creek nuggets and their included mineral phases; nor have we found any previous reference to native mercurian silver alloys in the compositional range defined by our analytical data.

The native-silver and dycrasite association identified in nugget \#3 represents a bonanza-type silver assemblage as recognized in supergene deposits in the Chanarcillo deposit in Chile and elsewhere (Guilbert and Park, 1986), implying that the Hunter Creek nuggets are related to bonanza-type silver deposits. This possibility merits the attention of the Alaskan mining and exploration community.

\section{THE ENIGMA OF NATIVE MERCURIAN-SILVER ALLOYS}

Although our literature search for previously described native mercurian-silver alloys in epithermal mineral deposits or placer concentrates, or both, was unsuccessful, we found some interesting documentation of man-made alloys in the compositional range of $\mathrm{Ag}_{5} \mathrm{Hg}_{8}$ (Azaroff, 1960). According to Azaroff, this alloy is one of the "electron" or "Hume-Rothery" compounds in which the electron:atom ratio is 21:13 with structures very similar to the structure of brass. However, the silver-mercury compositions documented by our analytical data are apparently outside of the limited solubility range described by Azaroff, and we have been unable to find a silver-mercury temperature-composition diagram 
that documents the parameters for permissible binary compositions in this system. Clearly, the structural state and metallurgical fabric of these native silver-mercury alloys should be analyzed in more detail, and the literature should be further screened for references to such alloys in man-made or natural states.

\section{ACKNOWLEDGMENTS}

Warren Yeend (USGS) and Steve R. Morison (Yukon Northern Affairs Program) reviewed an early draft of this paper. Ellen E. Harris (DGGS) prepared the final illustrations.

\section{REFERENCES}

Azaroff, L.V., 1960, Introduction to solids: New York, McGraw-Hill Book Co., p. 296.

Guilbert, J.M., and Park, Charles, Jr., 1986, The geology of ore deposits: New York, W.H. Freeman and Co., p. 829-830. 


\title{
LATE PLEISTOCENE VOLCANIC DEPOSITS NEAR THE VALLEY OF TEN THOUSAND SMOKES, KATMAI NATIONAL PARK, ALASKA
}

\author{
By \\ DeAnne S. Pinney ${ }^{1}$ and James E. Begét ${ }^{1}$
}

\section{INTRODUCTION}

One of the most notable events in the volcanic history of the Alaska Peninsula was the 1912 ignimbriteproducing eruption at Novarupta and the accompanying collapse of the summit of Mt. Katmai. The eruption transformed the valley north of Katmai Pass into the steaming, pumice-covered wasteland now known as the Valley of Ten Thousand Smokes (VTTS), which has been the focus of considerable scientific interest and research. Our studies of pre-1912 deposits there have yielded a richly detailed history of latest Quaternary glaciation and volcanism that has previously been largely overlooked. This paper examines one aspect of this history: the wide variety of deposits, including pyroclastic flows, lahars, lahar-runout flows, and fallout tephra as well as associated redeposited materials that were generated by a major volcanic eruption of late Wisconsin age in the Katmai area. Informally named Lethe tephra (Pinney and Begét, 1990), this group of deposits is an important marker horizon in the study area and has great potential for tephrochronology on the Kenai Peninsula.

\section{GEOGRAPHIC SETTING}

The Windy Creek study area is located immediately west of VTTS on the northern Alaska Peninsula (fig. 1). The spine of the Alaska Peninsula is a series of volcanoes that generally hug the southern coast. Recently active peaks include Mts. Mageik, Trident, Katmai, and St. Augustine. Broad lowlands bordering Bristol Bay in the northern half of the peninsula are dominated by a series of large moraine-dammed lakes. Drainages in the Windy Creek area empty into Iliuk Arm of one such lake, Naknek Lake, via Ukak River and Margot Creek.

\section{LETHE TEPHRA}

\section{Overview}

Lethe tephra is composed of an extensive suite of dacitic deposits, including pyroclastic flows, lahars, lahar-

${ }^{1}$ Department of Geology and Geophysics, University of Alaska Fairbanks, Fairbanks, Alaska 99775. runout flows, and primary and reworked fallout tephra. These deposits are exposed in river gorges in VTTS as far as $1.5 \mathrm{~km}$ upvalley from the mouth of Windy Creek valley and extend about $5 \mathrm{~km}$ past Windy Creek in the hanging valley south of Three Forks Overlook (fig. 2). Fallout tephra near Homer on the Kenai Peninsula has been geochemically correlated with Lethe tephra. Fluvially reworked Lethe pumice has also been identified over 20 $\mathrm{km}$ away in latest Pleistocene delta deposits that appear to be graded to former Brooks Lake shorelines. Lethe deposits overlie Iliuk drift of late Wisconsin age in the Windy Creek area and are overlain by and incorporated into drifts of latest Wisconsin and earliest Holocene age (Pinney and Begét, in press). Organic silt immediately underlying these later drifts yields a younger limiting date of 12,640 \pm 100 yr B.P. (Beta-33666) for Lethe tephra (Pinney and Begét, in press), making it a potentially important latest Pleistocene marker horizon. The source of this tephra is presently unknown, but exposures of Lethe volcaniclastic deposits in deep streamcuts along River Lethe more than a kilometer south of the confluence of VTTS and Windy Creek valley indicate an origin at the head of VTTS, as does the lack of significant primary Lethe deposits in Windy Creek valley. Possible sources include Mt. Mageik and dacite domes surrounding Novarupta (for example, Mt. Cerberus and Falling Mountain).

Glass chemistry of Lethe tephra is very homogeneous throughout the wide variety of deposits. Table 1 summarizes results of extensive electron-microprobe analysis of Lethe glass, including a distal ash sample from near Homer. From 10 to 35 glass shards were analyzed in each sample, providing standard deviations of less than 0.50 for most sample oxides. Because of the high degree of similarity among all analyses, the mean composition given in table 1 can be considered representative of Lethe tephra as a whole. Figures 3 and 4 plot glass compositions of reference samples of Lethe tephra and samples of 1912 VTTS ashflow rhyolite, dacite, and andesite (Avery, unpublished data), illustrating significant chemical distinctions between these deposits. Figure 5 plots the mafic-phenocryst content of Lethe tephra and 1912 deposits. Lethe phenocryst assemblages overlap with VTTS dacite but are distinct from VTTS rhyolite and andesite, reflecting the dacitic composition of the Lethe material. 


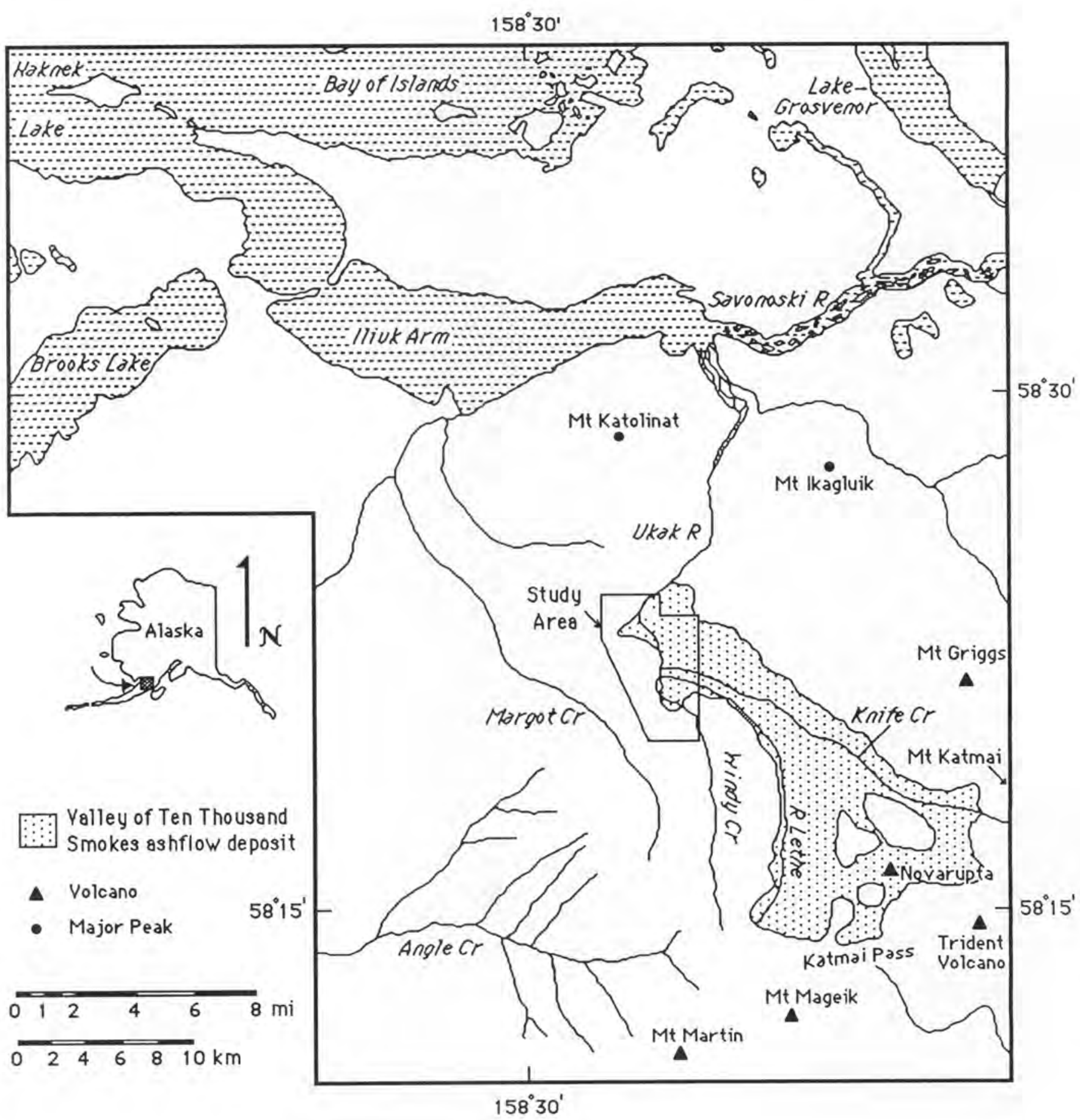

Figure 1. Location of Windy Creek study area relative to nearby features in Katmai area.

\section{STRATIGRAPHY}

\section{LAHAR AND LAHAR-RUNOUT FLOW DEPOSITS}

Lahar and lahar-runout flow deposits of Lethe tephra are commonly associated and are volumetrically the largest components of the suite exposed in the study area (fig. 2). Lahar deposits consist predominantly of fairly well-rounded, buff-to-yellow, coarse, bedded pumice in a coarse sandy matrix. Beds are 1- to 3-m thick and are reversely graded in the lowest part of each flow unit. Scattered, prismatically-fractured pumice clasts and discoloration of pumice and surrounding sediments 


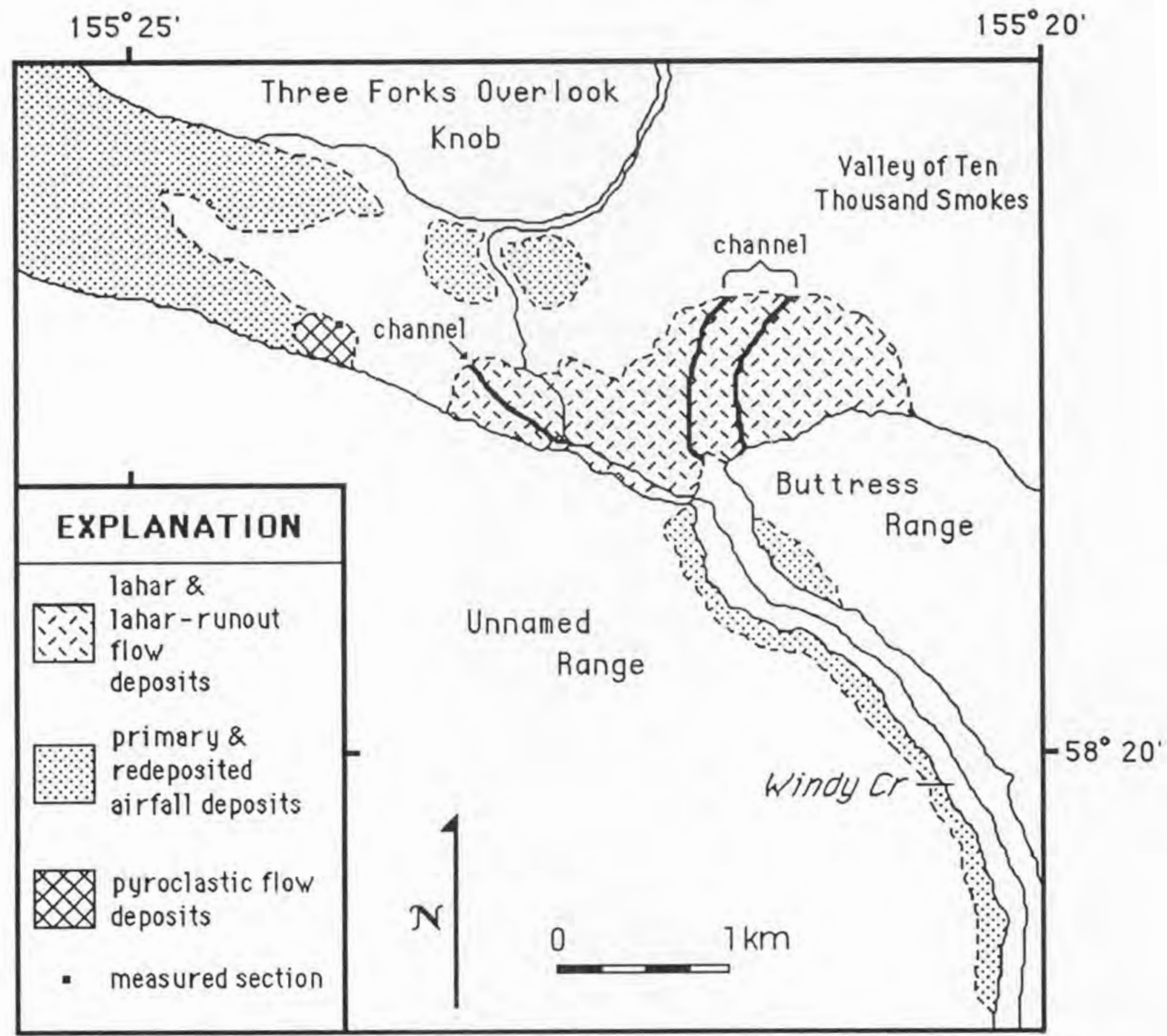

Figure 2. Distribution of Lethe tephra components. Unit descriptions based on dominant deposit type. Contacts dashed where approximate. Contacts bordering VTTS inferred and reflect deep streamcuts exposing Lethe deposits buried by 1912 ignimbrite. Heavy lines represent stream channels buried by 1912 ash flow and related deposits.

indicate that these lahars were emplaced while still hot or contained hot clasts, as do rare sintered, glassy blocks associated with possible fumarolic activity.

The sandy matrix of these pumiceous lahars is virtually identical to sandy lahar-runout flow deposits with which they are usually interbedded. The coarse, yellow-brown lithic sands of these deposits approach thicknesses of $30 \mathrm{~m}$ in some stream cuts, where they form near-vertical, indurated cliffs. Their volcanic origin is confirmed by the character of the fine fraction, which is almost pure glass with chemistry indistinguishable from Lethe pumice (table 1). The lower 10 to $15 \mathrm{~m}$ of the thickest lahar-runout flow deposits are planar beds up to $2 \mathrm{~m}$ thick, and the upper 15 to $20 \mathrm{~m}$ have climb- ing ripple beds 10 - to $30-\mathrm{cm}$ thick, which are typical of high-concentration flow deposits. Water-escape "dish" and "pillar" structures are locally very abundant and are present throughout many meters of section in some areas.

Large isolated clasts of sedimentary and volcanic lithologies up to $0.5 \mathrm{~m}$ in diameter are present in the sand, and a possible till rip-up clast was also identified. Smaller clasts are abundant and are usually distributed in chains or zones of concentration. Rare, gravel-filled channels are present near the base of the lahar-runout flow sands.

Overlying lahar-runout flow deposits in erosional contact (locally in channels) are 0.5- to 4-m-thick, waterlaid, crossbedded pumice and gravel. The presence of rare, 
Table 1. Glass compositions and mafic-phenocryst contents of reference Lethe tephra samples. Major oxides in glass separates given in normalized weight percent. Total Fe expressed as FeO*. One standard deviation in weight percent given below each oxide concentration. Number of analyses per sample $=n$. Relative proportions of clinopyroxene, orthopyroxene, and amphibole expressed as cp/op/am. Descriptions of analyzed samples given in footnote. Also included are correlative stream-redeposited pumice lapilli from near Brooks Lake (BP), average glass composition of Lethe tephra from reference samples (LETHE MEAN), and correlative distal-ash sample from near Homer (89-H-2-1). Analytical methods after Begét and others (1991)

\begin{tabular}{|c|c|c|c|c|c|c|c|c|c|c|c|}
\hline Sample & $\mathrm{n}$ & Type & $\mathrm{SiO}_{2}$ & $\mathrm{Al}_{2} \mathrm{O}_{3}$ & $\mathrm{Na}_{2} \mathrm{O}$ & $\mathrm{FeO}^{*}$ & $\mathrm{CaO}$ & $\mathrm{K}_{2} \mathrm{O}$ & $\mathrm{MgO}$ & $\mathrm{TiO}_{2}$ & cp/op/am \\
\hline \multirow[t]{2}{*}{ WC9-X } & 18 & a & 72.13 & 13.75 & 4.12 & 3.27 & 2.52 & 2.41 & 0.67 & 0.61 & $29 / 61 / 2$ \\
\hline & & & 0.50 & 0.22 & 0.19 & 0.20 & 0.16 & 0.07 & 0.07 & 0.03 & \\
\hline \multirow[t]{2}{*}{ WC15-A } & 10 & a & 71.64 & 14.05 & 4.19 & 3.16 & 2.74 & 2.35 & 0.76 & 0.54 & $21 / 74 / 5$ \\
\hline & & & 0.21 & 0.18 & 0.14 & 0.11 & 0.08 & 0.06 & 0.05 & 0.04 & \\
\hline \multirow[t]{2}{*}{ WC15-E } & 13 & $\mathrm{a}$ & 72.00 & 13.93 & 4.16 & 3.03 & 2.65 & 2.40 & 0.73 & 0.65 & $19 / 74 / 7$ \\
\hline & & & 0.46 & 0.18 & 0.24 & 0.24 & 0.21 & 0.08 & 0.07 & 0.07 & \\
\hline \multirow[t]{2}{*}{ WC15-Hd } & 11 & a & 71.65 & 13.99 & 4.27 & 3.17 & 2.65 & 2.40 & 0.77 & 0.61 & $27 / 71 / 2$ \\
\hline & & & 0.30 & 0.11 & 0.10 & 0.20 & 0.13 & 0.06 & 0.05 & 0.04 & \\
\hline \multirow[t]{2}{*}{ WC15-Hl } & 10 & a & 71.81 & 13.95 & 4.22 & 3.19 & 2.57 & 2.39 & 0.75 & 0.67 & 23/68/9 \\
\hline & & & 0.23 & 0.11 & 0.08 & 0.13 & 0.11 & 0.07 & 0.03 & 0.07 & \\
\hline \multirow{2}{*}{ WC16-X } & 16 & $\mathrm{~b}$ & 72.05 & 13.76 & 4.34 & 3.18 & 2.50 & 2.35 & 0.68 & 0.62 & $22 / 78 / 0$ \\
\hline & & & 0.49 & 0.15 & 0.15 & 0.19 & 0.13 & 0.10 & 0.05 & 0.06 & \\
\hline \multirow{2}{*}{ WC34-X } & 21 & c & 72.54 & 13.82 & 4.04 & 2.93 & 2.47 & 2.46 & 0.68 & 0.61 & $32 / 55 / 13$ \\
\hline & & & 0.62 & 0.19 & 0.16 & 0.28 & 0.15 & 0.07 & 0.06 & 0.06 & \\
\hline \multirow[t]{2}{*}{ WC36-SI } & 35 & d & 72.28 & 13.87 & 4.33 & 3.13 & 2.51 & 2.35 & 0.70 & 0.62 & $26 / 67 / 0$ \\
\hline & & & 0.34 & 0.14 & 0.10 & 0.31 & 0.10 & 0.09 & 0.05 & 0.07 & \\
\hline \multirow[t]{2}{*}{ WC50-X } & 15 & a & 72.11 & 13.83 & 3.97 & 3.25 & 2.62 & 2.38 & 0.70 & 0.64 & $37 / 61 / 1$ \\
\hline & & & 0.43 & 0.15 & 0.25 & 0.16 & 0.17 & 0.06 & 0.05 & 0.05 & \\
\hline \multirow[t]{2}{*}{ BP-1 } & 15 & e & 72.12 & 13.96 & 4.15 & 2.99 & 2.65 & 2.33 & 0.71 & 0.61 & 19/81/0 \\
\hline & & & 0.35 & 0.17 & 0.13 & 0.21 & 0.15 & 0.05 & 0.07 & 0.05 & \\
\hline \multirow[t]{2}{*}{ BP-2 } & 17 & e & 71.84 & 13.94 & 4.22 & 3.10 & 2.69 & 2.34 & 0.73 & 0.65 & 28/69/2 \\
\hline & & & 0.19 & 0.15 & 0.13 & 0.12 & 0.13 & 0.05 & 0.03 & 0.05 & \\
\hline \multirow{2}{*}{$\begin{array}{l}\text { LETHE } \\
\text { MEAN }\end{array}$} & 11 & - & 72.02 & 13.90 & 4.18 & 3.13 & 2.60 & 2.38 & 0.72 & 0.62 & $-1-1-$ \\
\hline & & & 0.27 & 0.10 & 0.11 & 0.12 & 0.09 & 0.04 & 0.03 & 0.03 & \\
\hline \multirow[t]{2}{*}{ 89-H-2-1 } & 16 & $\mathrm{f}$ & 72.37 & 13.88 & 4.31 & 3.07 & 2.56 & 2.34 & 0.70 & 0.62 & $-1-1-$ \\
\hline & & & 0.30 & 0.13 & 0.14 & 0.13 & 0.09 & 0.06 & 0.04 & 0.05 & \\
\hline pe. & & redep & i pumic & & $\begin{array}{l}\text { led pum } \\
1 \text { fine as }\end{array}$ & $\begin{array}{l}\text { dep } \\
\text { lock }\end{array}$ & & & & & \\
\hline
\end{tabular}


intact, breadcrust bombs in these deposits indicates that they were associated with volcanic activity that continued after emplacement of lahars and related deposits.

The surface of the valley fill composed of volcaniclastic deposits is largely buried by the 1912 ignimbrite, but exposures in banks along Windy Creek and River Lethe demonstrate that it is fairly flat and slopes gently northwest, indicating that the material was derived from upper VTTS. The Lethe-age surface is incised by at least two abandoned channels of Windy Creek (fig. 2). A smaller, gravel-filled western channel may reflect stream diversion by glaciers during latest Pleistocene or earliest Holocene time, and the larger eastern channel was likely the course of Windy Creek immediately before the 1912 eruption.

The concept of lahar-runout flows is new, so we believe it is important to discuss deposition and characteristics of the flows and to present evidence in support
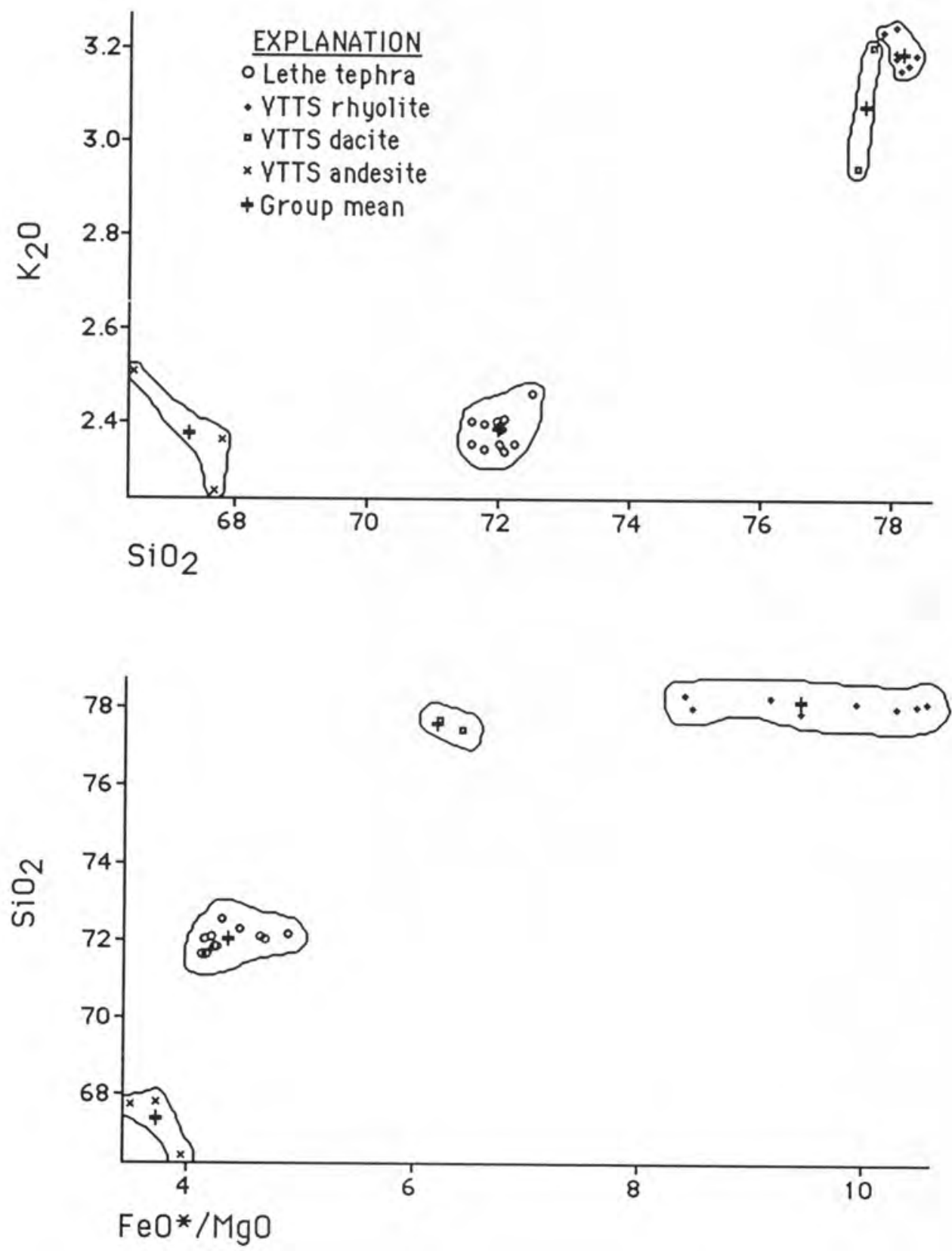

Figure 3. Glass compositions of reference samples of Lethe tephra and samples of 1912 VTTS ash flow (Avery, unpublished data) in plots of $\mathrm{K}_{2} \mathrm{O}$ and $\mathrm{FeO} * / \mathrm{Mg}$ against $\mathrm{SiO}_{2}$. Outlines around groups emphasize chemical distinctions. 


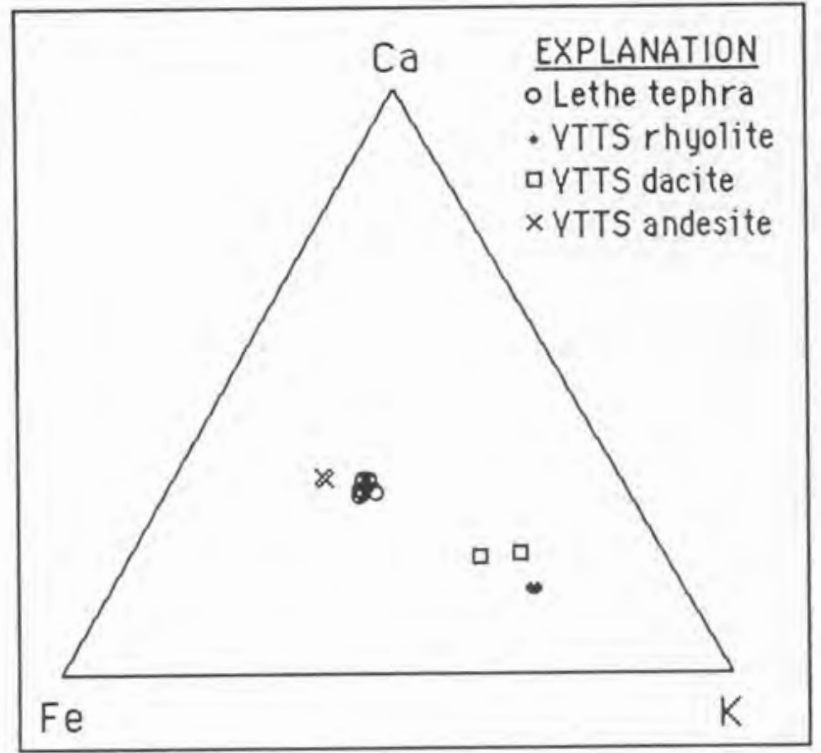

Figure 4. $\mathrm{Ca}-\mathrm{Fe}-\mathrm{K}$ plots of glass compositions of reference samples of Lethe tephra and samples of 1912 VTTS ash flow (Avery, unpublished data).

of a lahar-runout flow origin for the thick sand sequences in lower Windy Creek. Definitive studies of lahars and their associated runout flows were accomplished by Scott $(1988,1989)$ on lahars of the recent eruption of Mt. St. Helens, as well as several of its older debris flows. Transformation of lahars into runout flows involves debulking through progressive incorporation of overrun streamflow. Hyperconcentrated streamflow, described by Scott (1988) as flow containing 40 to 80 percent sediment by weight or 20 to 60 percent by volume (400,000 to $800,000 \mathrm{ppm}$ ), results when increased water content causes a significant loss in yield strength. This change, which occurred in channel distances as great as $19 \mathrm{~km}$ at Mt. St. Helens, is thought to be facilitated by low clay content in the lahar and thus low cohesiveness, which allows greater miscibility with streamflow (Scott, 1988). When this transition threshold is reached, coarse clasts are deposited due to loss of yield strength, and fine silt and clay may be separated by drainage of interstitial water as the flow continues. Adding more water eventually dilutes laharrunout flow to normal stream flow. Runout phases of some lahars at Mt. St. Helens were large enough to bury entire floodplains farther than $80 \mathrm{~km}$ from the volcano (Scott, 1988).

Lahar-runoutflow deposits generated at Mt.St. Helens in 1980 and 1982 are generally massive to crudely stratified silt and 2- to 4-mm-diameter sand with particle- or clast-supported textures (Scott, 1988; 1989). Modal size

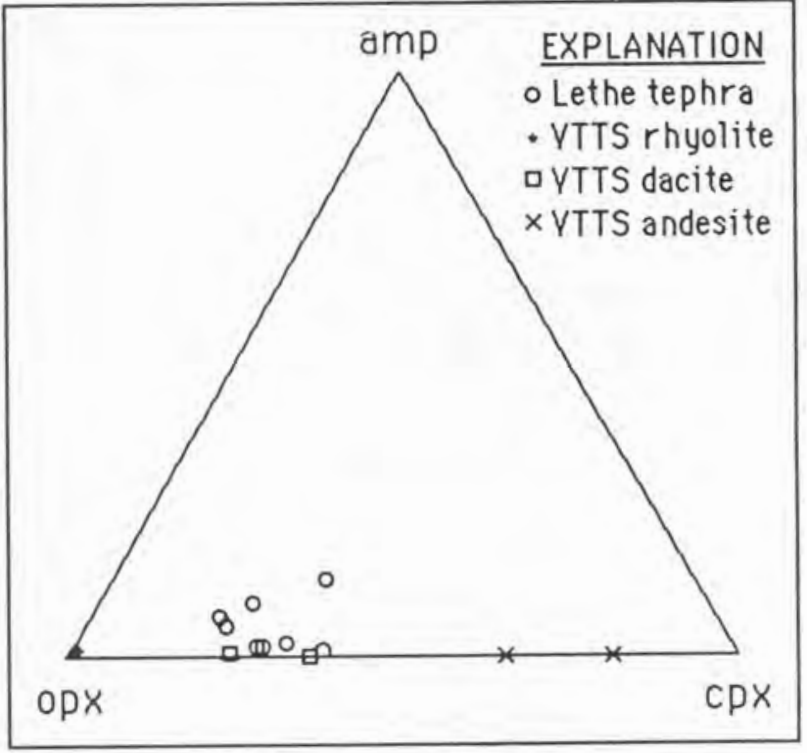

Figure 5. Mafic-phenocryst contents of reference samples of Lethe tephra and samples of 1912 VTTS ash flow (Avery, unpublished data). Plot vertices are amphibole (amp), orthopyroxene (opx), and clinopyroxene (cpx).

is in the sand range, commonly 0.2 to 2.0 phi $(0.25-0.9$ $\mathrm{mm}$ ). This granularity is thought to reflect inclusion of sediments subject to previous sorting by explosive or hydraulic processes. Sorting is characteristically 1.1 to $1.6 \mathrm{phi}$, in a range intermediate between debris-flow deposits and most normal streamflow deposits (fig. 6). Clay content is low, commonly less than 3 percent.

Grain-size analysis was performed on samples of Lethe lahar-runout flow sediments for comparison with Mt. St. Helens deposits. Two samples of generally massive, particle-supported Lethe sands plot virtually the same and are in the range of lahar-runout flow deposits, although the curves are slightly steeper than Scott's curves (fig. 6). Sorting is on the order of $1.08 \mathrm{phi}$, and modal grain size, at $0.70 \mathrm{phi}$, is also well within the indicated range. Lethe clay contents of much less than 3 percent are typical of lahar-runout flow deposits.

Water-escape structures have not been reported at Mt. St. Helens but are in some Lethe deposits. Dish structures are very widespread, indicating that Lethe deposits were formed by water-saturated flows with high sediment concentrations. Pillars between upward-curving margins of dishes represent fluidization channels developed through permeable sediment. According to Lowe (1975), pillars of this kind (type A) are uncommon and irregularly spaced where dewatering occurred relatively slowly and tend to be common and regularly spaced where consolidation involved near-complete sediment 


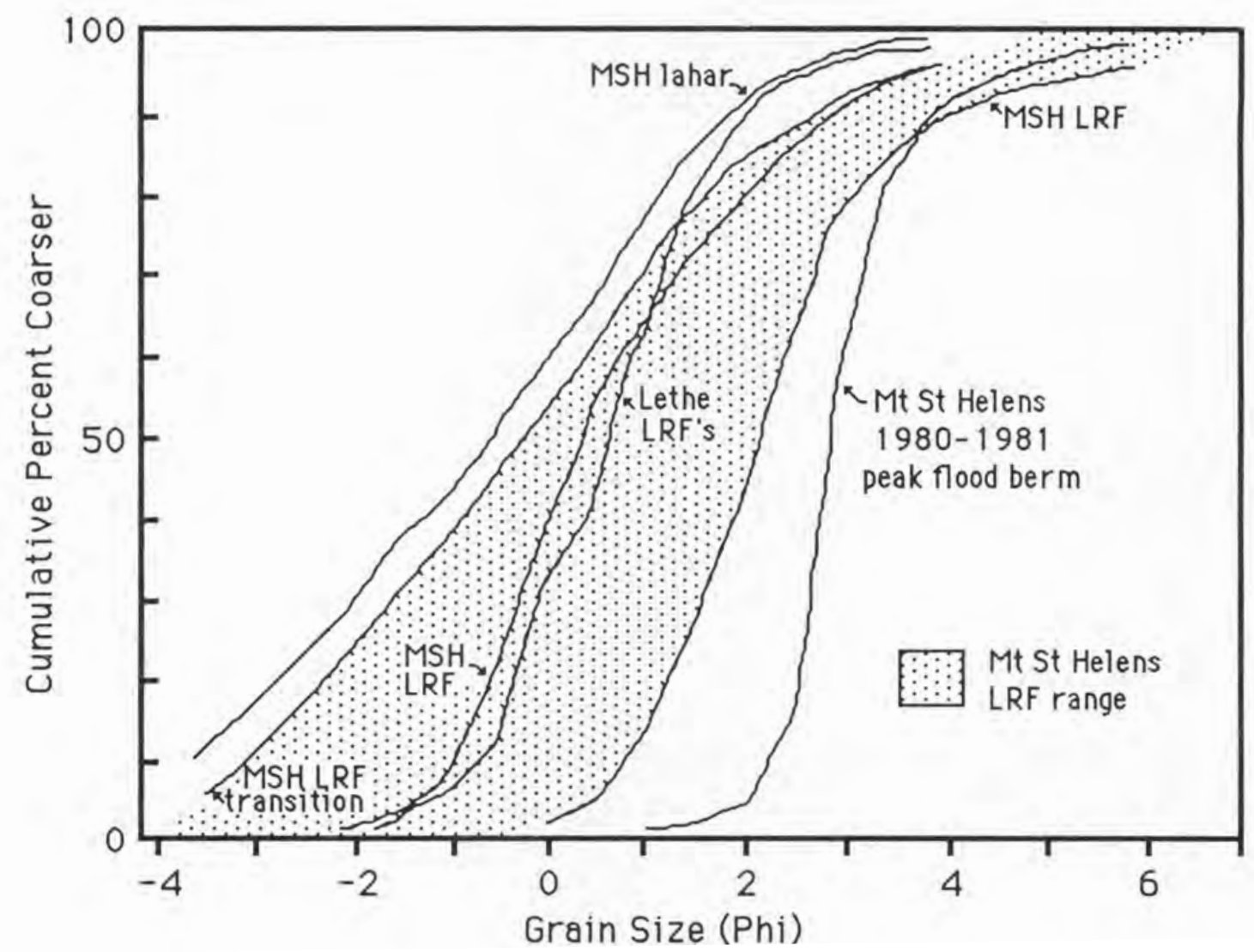

Figure 6. Cumulative curves of particle sizes in Lethe lahar-runout flows (LRF) plotted against curves for Mt. St. Helens (MSH) deposits, including lahar-runout flows, lahars, deposits from the lahar- to lahar-runout flow transition, and flood deposits. Lethe curve represents analyses of two samples that plot virtually indentical and fall in the range of Mt. St. Helens LRF deposits. Mt. St. Helens data from Scott (1988).

liquefaction. With regard to clay-poor runout deposits, it is significant that these specific structures are found in loosely packed sand without the impermeable clays and silts generally required for most dewatering structures (Lowe, 1975). We suggest that water-escape structures developed at Windy Creek but not at Mt. St. Helens due to the much greater thickness of lahar-runout flow deposits in the Windy Creek area (up to $30 \mathrm{~m}$ compared with 2.5 $\mathrm{m}$ ), which produced higher overburden pressures in pore fluids. These flows may also have interacted with water, snow, or ice during deposition because large glaciers may have existed in upper VTTS during the eruption.

\section{PYROCLASTIC-FLOW DEPOSITS}

Pyroclastic-flow deposits are rare in Lethe valleyfill deposits but are locally preserved beyond the limits of the 1912 ignimbrite on moraines southwest of Three Forks Overlook (fig. 2). These deposits provide important evidence that active volcanism accompanied deposition of
Lethe debris-flow deposits and was sufficiently vigorous to send primary pyroclastic flows many kilometers from their source. Lethe pyroclastic flows produced unwelded pumice-flow deposits that are composed of abundant pumice blocks and lapilli and less than 50 percent ash (as defined by Fischer and Schmincke, 1984). Exposures of several flows in a long gully cut across a morainal crest (fig. 7) display angular-to-subrounded, prismaticallyfractured, buff dacitic pumice that is locally clast supported and openwork. A pumice-flow deposit up to $6 \mathrm{~m}$ thick, including several well-developed fossil fumaroles, extends more than $90 \mathrm{~m}$ to the mouth of the gully where it thins over an 8-m thickness of exposed late Wisconsin-age Iliuk till. In most places, beds of pyroclastic-flow pumice are topped by variable thicknesses of wind-reworked Lethe tephra and soil-forming silts. Pumice blocks and bombs locally exceed $60 \mathrm{~cm}$ in diameter. Flow units up to $5 \mathrm{~m}$ thick are normally graded. In one 3-m-thick exposure, $50 \mathrm{~cm}$ of 10 - to 20 -cm-diameter pumice at the top grades downward into more than $2.5 \mathrm{~m}$ of larger pumice and 
bombs. Baked contacts are present locally.

The presence of Lethe pyroclastic-flow deposits beyond the limits of the 1912 ignimbrite indicates that Lethe flows were extremely mobile and may have had emplacement velocities greater than the VTTS flow (Begét and Limke, 1988). Lethe ignimbrites blanketing the Iliuk lateral moraine are about $1 \mathrm{~km}$ beyond the 1912 terminus. Based on the runup method (Begét and Limke, 1988), Lethe flows must have been travelling at least $12 \mathrm{~m} / \mathrm{s}$ at this location to overtop the moraine. Actual velocity may have been greater, depending on the total relief of the moraine at the time of flow emplacement. Pyroclastic flow deposits at this location are approximately 20 to 25 $m$ higher than the top of Lethe valley-fill deposits in lower
Windy Creek. Calculations using these criteria yield a minimum velocity of 19 to $22 \mathrm{~m} / \mathrm{s}$.

\section{PRIMARY AND REWORKED FALLOUT DEPOSITS}

Primary Lethe fallout pumice overlies deposits of Iliuk age and older in the Windy Creek area, where former surfaces were too gentle to allow much downslope washing, but most outcrops of Lethe tephra consist of reworked ash and lapilli. Buff pumice lapilli up to $2 \mathrm{~cm}$ in diameter are scattered on Iliuk moraines below Three Forks Overlook and lapilli about $1 \mathrm{~cm}$ in diameter are dispersed in a paleosol overlying Iliuk-age glaciolacustrine deposits in

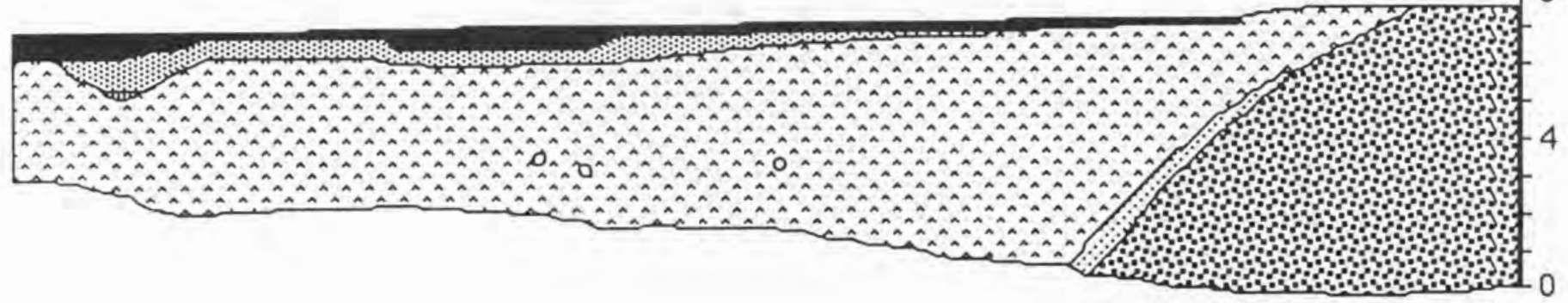

\section{EXPLANATION}

\section{Five lill forming lateral moraine}

\section{Fluvial gravel}

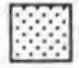

Bedded silt and clay

$\circ$

Fossil fumarole $\therefore$ Lethe pyroclastic flow deposits; buff dacitic pumice to $60 \mathrm{~cm}$ diameter in normally graded flow units

Wind-reworked Lethe tephra; crystal-rich ash

Eolian silt and rooty duff

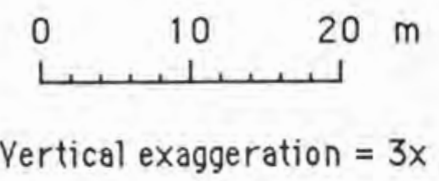

Figure 7. Geologic cross section through Lethe tephra deposits exposed in natural gully west of lower Windy Creek. Volcaniclastic deposits override a lateral moraine of the late Wisconsin Iliuk glaciation. 
Windy Creek valley. Thicknesses of crystal-rich sandy ash locally exceed $1.25 \mathrm{~m}$ on the floor of the hanging valley south of Three Forks Overlook, although these exceptional thicknesses are probably due in part to eolian deposition on leeward surfaces. Structures observed in Lethe ash deposits are analogous to structures in cross sections through dunes of 1912 tephra. We are uncertain how much of this ash can be attributed to airfall and how much was derived by eolian winnowing of pyroclastic flows and sandy lahar and lahar-runout flow deposits.

Fluvially reworked Lethe airfall pumice is widely distributed in the study area (fig. 2) and has been identified in delta deposits overlain by outwash at Brooks Lake. Concentration of slopewash material along the walls of Windy Creek valley has produced deposits of bedded pumice and sand that locally reach thicknesses of $6 \mathrm{~m}$. Typical buff-to-yellow pumice clasts in a coarse sandy matrix are very well rounded and up to $15 \mathrm{~cm}$ in diameter. Rare brownish pumice clasts are locally dispersed among light-toned clasts. Bedding is planar to crossbedded, and bed thickness varies from 1 to $30 \mathrm{~cm}$. Interbedded with pumice units are coarse sands and local fluvial gravels. The sand is typically composed of distinctive dark- and light-toned mineral grains, giving it a characteristic saltand-pepper appearance. Small pebbles of Jurassic Naknek Formation are common throughout reworked Lethe deposits in Windy Creek valley. Extensive reworking of Lethe pumice is also evident at the lip of the hanging valley overlooking Margot Creek drainage (fig. 2), where fine-grained, thin-bedded pumice and lapilli are exposed in sections thicker than $2 \mathrm{~m}$.

\section{CONCLUSIONS}

Excellent exposures in the Windy Creek area near the Valley of Ten Thousand Smokes allow detailed study and description of proximal deposits of late-Pleistocene Lethe tephra. Stratigraphic relations between its various components and with significant glacial deposits provide evidence of its depositional environment and yield important chronological constraints on the latest Wisconsin and earliest Holocene glacial succession in the area. Lethe tephra is an important marker horizon in the study area and is known to extend to the Kenai Peninsula, where a correlative ashfall tephra is identified in the Homer area by geochemical comparison with proximal Lethe deposits. Distribution of Lethe tephra is likely to increase as more extensive tephra studies are conducted.

\section{ACKNOWLEDGEMENTS}

This paper was reviewed by James R. Riehle(USGS) and Richard D. Reger(DGGS). The generosity of Victoria F. Avery (UAF) in sharing her geochemical data on the 1912 ignimbrite is deeply appreciated. Financial support for this project provided in part by the Alaska Center for Tephrochronology (ACT), Alaska Quaternary Center (AQC), Alaska Volcano Observatory (AVO), University of Alaska Department of Geology and Geophysics, and the UA Foundation through the Peter McKeith Memorial Scholarship.

\section{REFERENCES}

Begét, J.E., and Limke, A.J., 1988, Two-dimensional kinematic and rheological modeling of the 1912 pyroclastic flow, Katmai, Alaska: Bulletin of Volcanology, v. 50, no. 3, p. 148-160.

Begét, J.E., Reger, R.D., Pinney, DeAnne, Gillispie, Tom, and Campbell, Kathy, 1991, Correlation of the Holocene Jarvis Creek, Tangle Lakes, Cantwell, and Hayes tephras in south-central and central Alaska: Quaternary Research, v. 35, no. 2, p. 174-189.

Fischer, R.U., and Schmincke, H.-U., 1984, Pyroclastic rocks: Berlin, Springer-Verlag, $472 \mathrm{p}$.

Lowe, D.R., 1975, Water escape structures in coarsegrained sediments: Sedimentology, v. 22, no. 2, p. 157-204.

Pinney, D.S., and Begét, J.E., 1990, Quaternary tephrochronology near the Valley of Ten Thousand Smokes, Katmai National Park, Alaska [abs]: EOS, Transactions, American Geophysical Union, v. 71, no. 43, p. 1721.

in press, Deglaciation and latest Pleistocene and early Holocene glacier readvances on the Alaska Peninsula: Records of rapid climate change due to transient changes in solar intensity and atmospheric $\mathrm{CO}_{2}$ content?: Proceedings of the International Conference on the Role of the Polar Regions in Global Change.

Scott, K.M., 1988, Origins, behavior, and sedimentology of lahars and lahar-runout flows in the Toutle-Cowlitz River system: U.S. Geological Survey Professional Paper 1447-A, 76 p.

1989, Magnitude and frequency of lahars and lahar-runout flows on the Toutle-Cowlitz River system: U.S. Geological Survey Professional Paper 1447-B, 33 p. 



\title{
DEGLACIATION OF THE ALLISON-SAWMILL CREEKS AREA, SOUTHERN SHORE OF PORT VALDEZ, ALASKA
}

\author{
By \\ Richard D. Reger ${ }^{1}$
}

\section{INTRODUCTION}

Signs of intense glaciation dominate a rugged landscape in the Port Valdez area. Jagged bedrock ridge crests separate deep, U-shaped valleys that once served as conduits for fast-flowing ice streams born in nearby alpine cirque basins under dynamic conditions of cool temperature, heavy snowfall, and rapid ablation. Faceted ridge spurs, steep ice-planed and fluted valley walls, and the deep fiord all attest to effective scouring and plucking of the layered bedrock by formerly thick ice tongues. Along the southern shore of Port Valdez in the vicinity of Allison and Sawmill Creeks, fresh moraines and striations on ice-molded bedrock document a late resurgence of glaciers from tributary valleys after retreat of the large trunk glacier that formerly occupied Port Valdez (fig. 1; Williams and Coulter, 1981, p. B78).

The freshness of these ubiquitous signs invites the curious to ask, "How long ago was the ice here?" The purpose of this report is to present geologic evidence in the Allison-Sawmill Creeks area that will partially answer this question.

\section{EVIDENCE IN THE ALLISON- SAWMILL CREEKS AREA}

Intercalated metagraywacke and phyllitic argillite are dominant bedrock lithologies and greenstone is a minor bedrock component in the Allison-Sawmill Creeks area (Updike and Ulery, 1987). These foliated-to-massive rocks generally strike slightly north of east and dip steeply northward. Scouring by debris carried in the thick trunk glacier flowing down Port Valdez roughly parallel to rock layering differentially abraded this metamorphic sequence, leaving more competent metagraywacke units standing as streamlined (whaleback) ridges separated by deeply grooved, less competent layers of phyllitic argillite.

Silty gravel till deposited by the trunk glacier discontinuously covered the Allison-Sawmill Creeks area prior to construction of the marine terminal for the TransAlaska Pipeline System (TAPS). End moraines of this age, if present, are inconspicuous.

In the vicinity of lower Allison Creek and lower

${ }^{1}$ Alaska Division of Geological and Geophysical Surveys, 794 University Avenue, Suite 200, Fairbanks, AK 99709-3645.
Sawmill Creek, irregular small moraines formed by ice emanating from these two tributary valleys cut across bedrock ridges and grooves carved during the last major glaciation of Port Valdez (fig. 1). Sets of at least two moraines are recognized in each of these drainages; the most extensive (earliest) moraines are clearly related to ice advances and are associated with numerous smaller, less extensive, and discontinuous recessional moraines. Major still-stands or significant readvances are probably represented by the younger set of end moraines 910 to $1,880 \mathrm{~m}$ south of Port Valdez.

Paired lateral moraines record a former ice advance down Allison Creek beyond the southern shore of Port Valdez (fig. 1; Williams and Coulter, 1981). East of Allison Creek, part of the east lateral moraine abuts a massive rock slide, known locally as the Liscum or Fort Liscum slide (Williams and Johnson, 1980; Combellick, 1987), but in the lower canyon of Allison Creek, this moraine trends out into a gap left when a later bedrock failure dropped part of the east valley wall from beneath the moraine (fig. 1). Surface morphology indicates that the Liscum slide resulted from at least three successive failures.

Apair of small but obvious lateral moraines delineates a resurgence that advanced down Sawmill Creek beyond the present southern shore of Port Valdez but probably did not override Saw Island or Jackson Point (fig. 1). This advance produced a small proglacial fan of sandy gravel up to $6 \mathrm{~m}$ thick that dammed the west side of a local drainage and produced Swan Lake. During May 1975, while the east tank farm was being constructed, Swan Lake was drained by cutting through the sediment dam and basin sediments were subsequently removed preparatory to emplacement of a foundation for the large oil-storage tanks. Before its removal, I was given the opportunity to document a geologic section through the eastern margin of the Swan Lake basin and to collect several organic samples for dating the section. These dates and the associated paludal, fluvial, lacustrine, and glacial deposits provide evidence for the timing of lateglacial events in the area (fig. 2).

The Swan Lake section was $90 \mathrm{~m}$ long and 3.3 to $12.7 \mathrm{~m}$ deep (fig. 2). The eastern 40 percent of the section was cut through the distal part of a small, local alluvial fan (figs. 1 and 2). The western 20 percent exposed sedi- 


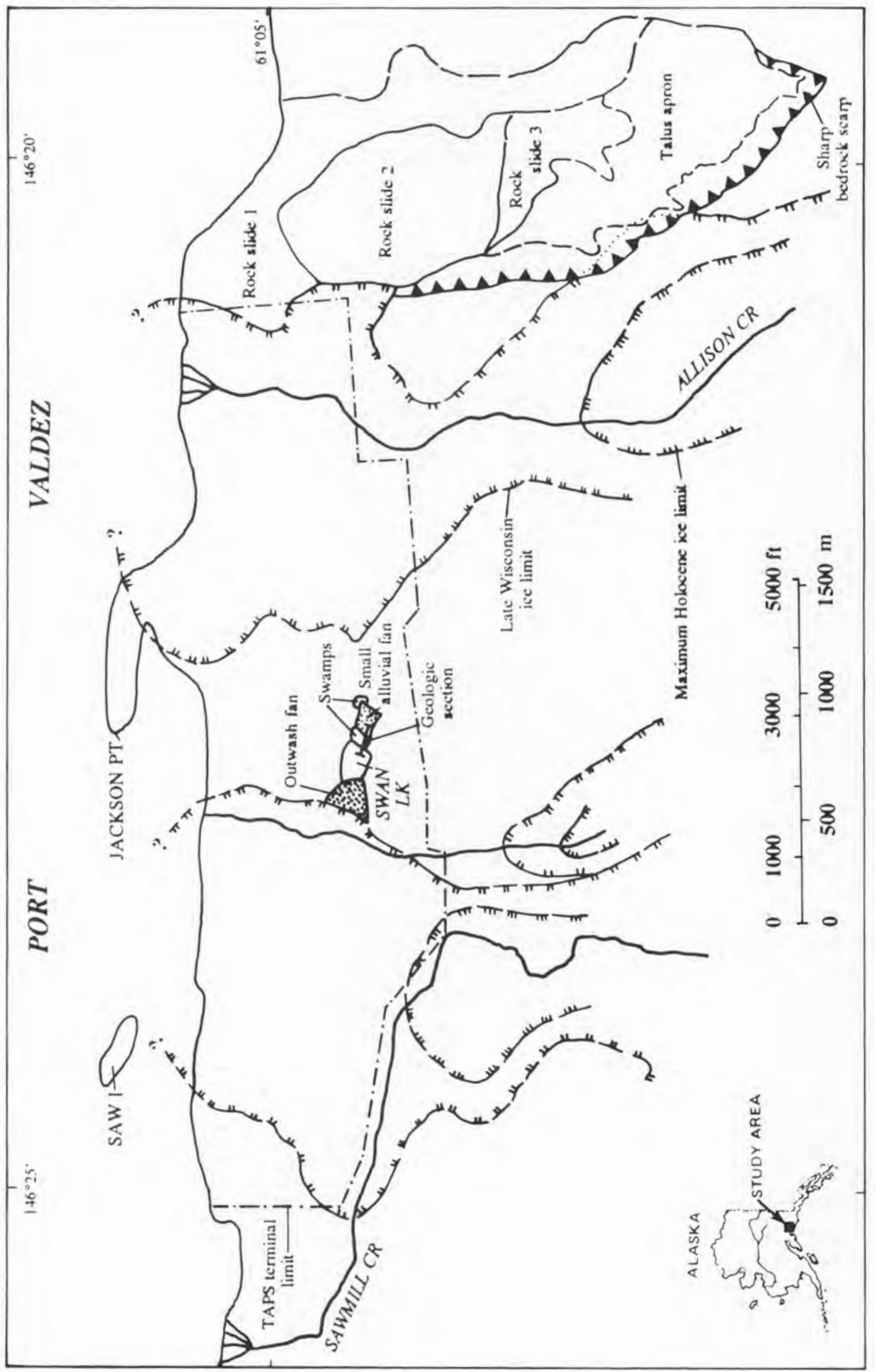

$\frac{1}{5} \frac{1}{5}$ हे

$\bar{\nabla} \approx \frac{\pi}{\pi}$

8.5

ปี

फे ह

ㅇำ

in

$\underset{-1}{\pi}$

ป छ

도워

ह 20

है ขै

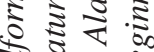

¿ै

어 월 호

< $\frac{2}{2}$

ธै ธิ इ

응 흐

¿

บ 0 ० ह

สิ่

के 2 ह

की

ป ฐ

है

$\leqq .0 \frac{5}{5} . \Xi$

ช

కँ

ฮั

ते

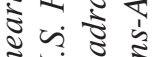

ㄱำ

\% के

ป ธิ

¿

ฟั. ำ

ปู ฮे

\% ㅎำ

वे 온

전도

วิ독

พิ่

โ 9

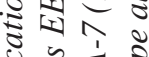

ปร

-

의 


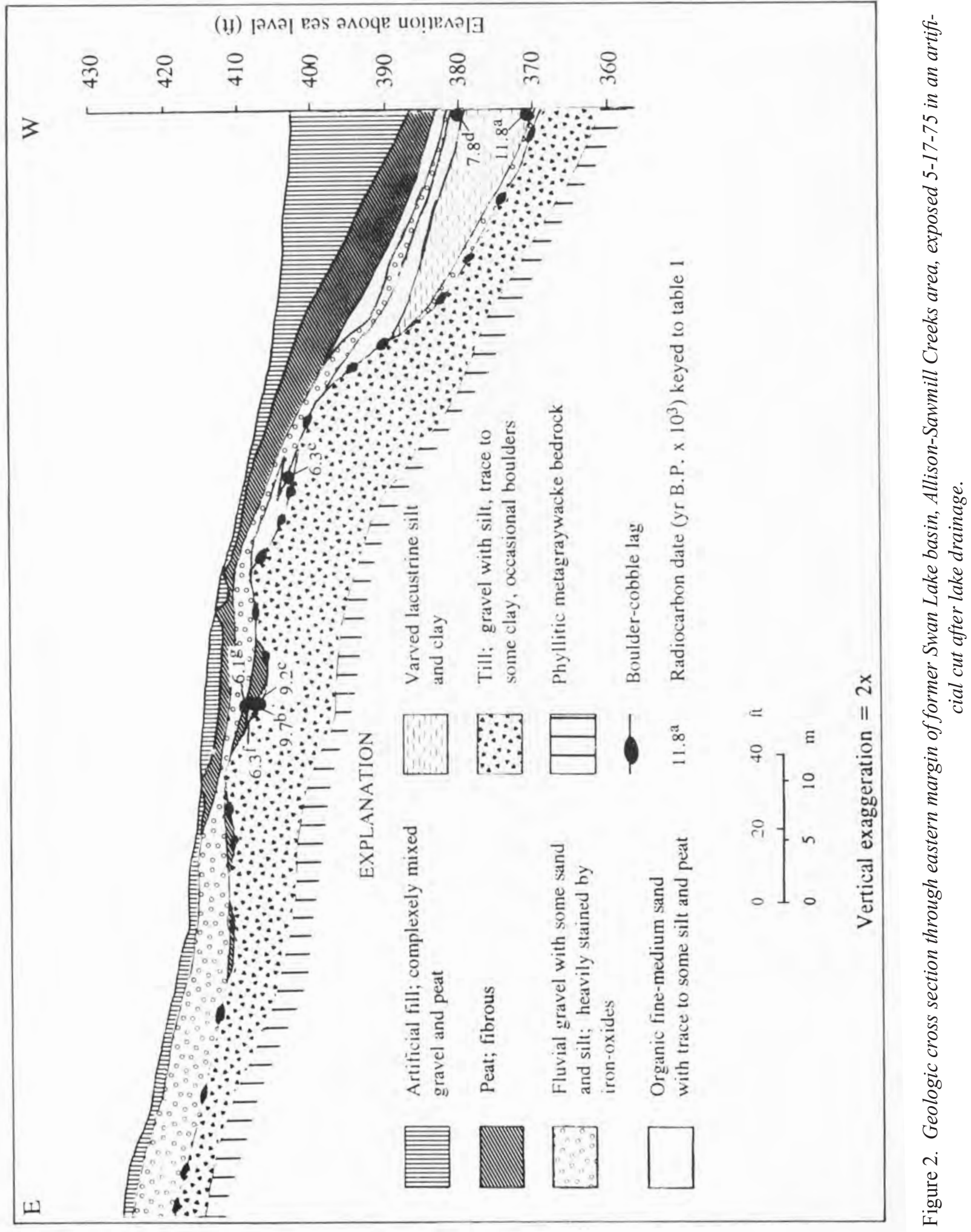


ments of the former lake, and the remaining 40 percent was cut through deposits beneath a lake-margin swamp.

A gently irregular, ice-scoured surface cut on phyllitic metagraywacke formed the base of the section, and between 1.2 and $5.5 \mathrm{~m}$ of medium-gray, compact, silty gravel till continuously covered the bedrock. At the top of the till was a discontinuous lag of subangular to subrounded cobbles and boulders. In the former lake basin, up to $0.3 \mathrm{~m}$ of sandy fluvial gravel, which overlay the cobble-boulder lag, was covered by as much as $3 \mathrm{~m}$ of laminated (varved) lacustrine silt and clay. Up to $0.8 \mathrm{~m}$ of silty organic lacustrine sand overlay the varved sediments and was overlain by up to $7 \mathrm{~m}$ of alluvial-fan gravel, organic sand, peat, and fill material. Sandy alluvial-fan gravel, heavily stained by iron oxides, had a maximum thickness of $1.8 \mathrm{~m}$ along the eastern edge of the section and thinned westward to $0.2 \mathrm{~m}$. This granular deposit buried lenses and tongues of paludal fine- to mediumgrained organic sand and fibrous peat and was in turn covered by similar paludal deposits (fig. 2). The upper peat had a maximum thickness of $1.8 \mathrm{~m}$ and was covered by up to $4.8 \mathrm{~m}$ of artificial fill.

Seven organic samples were collected from significant parts of the section and their radiocarbon ages were determined (fig. 2, table 1). Conventional radiocarbon dates of $11,820 \pm 560 \mathrm{yr}$ B.P. (GX-10,789) and 7,800 \pm 230 yr B.P. $(\mathrm{GX}-10,788)$ for the bottom and top of the lake section, respectively, indicate that varved sediments accumulated in the basin from 12,000 to 8,000 radiocarbon y.a. Five concordant conventional radiocarbon dates document local paludal deposition between 9,700 and 6,100 radiocarbon y.a. and demonstrate that significant alluvial-fan aggradation began at the site about 6,100 radiocarbon y.a.

\section{IMPLICATIONS}

\section{Deglaciation of Allison- Sawmill Creeks Area}

The oldest radiocarbon date in the Swan Lake section (table 1) provides evidence that the Allison-Sawmill Creek area was free of glacial ice before 12,000 radiocarbon y.a. The cobble-boulder lag at the top of the till and beneath the lacustrine section indicates that a significant period of exposure and subaerial erosion or nondeposition affected the till blanket after retreat of the trunk glacier and before formation of Swan Lake. Thus, the major period of deglaciation probably occurred several centuries or millenia before 12,000 radiocarbon y.a.

Physiographic and stratigraphic relations indicate that outwash derived from the glacier that readvanced out of the upper valley of Sawmill Creek blocked the mouth of a shallow, westward-sloping trough between the steep bedrock slope south of the TAPS terminal and a prominent ice-scoured bedrock ridge to form the Swan Lake basin (fig. 1). The date of $11,820 \pm 560$ radiocarbon yr B.P. (GX-10,789) for twigs, moss, and organic silt in basal lake deposits demonstrates that this blockage was produced by a glacial advance close to 12,000 radiocarbon y.a. (table 1).

Brief observations of weathering profiles developed on oldest lateral moraines of local derivation in the Allison-Sawmill Creeks area indicate that they bear well-developed spodzolic soils with elluvial (E) layers 7 to $12 \mathrm{~cm}$ thick and that maximum depths to the base of weathered till range from 0.9 to $1.5 \mathrm{~m}$. Degree of soil development is equal for moraines in both drainages, indicating that advances were simultaneous.

Although Lethcoe (1987, p. 124) assigned the oldest

Table 1. Summary of radiocarbon dates for geologic cross section exposed 5-17-75 in artificial cut through eastern margin of former Swan Lake basin, Allison-Sawmill Creeks area, keyed to figure 2.

\begin{tabular}{cll} 
Sample & & \multicolumn{1}{c}{ Material dated } \\
a & & Twigs, moss, and organic silt \\
b & & Peat and organic silt \\
c & & Wood \\
d & & Wood \\
e & & Organic silt \\
$\mathrm{f}$ & & Woody peat and organic silt \\
$\mathrm{g}$ & & Wood
\end{tabular}

\begin{tabular}{c}
$\begin{array}{c}\text { Conventional } \\
\text { radiocarbon } \\
\text { age (yr B.P.) }\end{array}$ \\
\hline $11,820 \pm 560$ \\
$9,660 \pm 290$ \\
$9,240 \pm 275$ \\
$7,800 \pm 230$ \\
$6,340 \pm 270$ \\
$6,285 \pm 245$ \\
$6,065 \pm 130$
\end{tabular}

Conventional

age (yr B P)

$11,820 \pm 560$

$9,660 \pm 290$

$7,800 \pm 230$

$6,285 \pm 245$

$6,065 \pm 130$
Laboratory sample number

GX-10,789

GX-10,787

GX-11,329

GX-10,788

GX-11,332

GX-11,330

GX-11,331 
east lateral moraine and associated recessional moraines in the Allison Creek drainage to a Neoglacial advance, they clearly predate the Holocene. This latest Wisconsin advance was coeval with an expansion of Finger Glacier in the eastern Lituya district shortly after 12,400 radiocarbon y.a. (Mann, 1986). Comparison with the late Quaternary chronology for the upper Cook Inlet region indicates that moraines in the Allison-Sawmill Creeks area correlate with the Elmendorf moraine in the Anchorage area. The Elmendorf moraine is dated younger than 13,690 \pm 400 radiocarbon yr B.P. (W-2151) and older than $11,690 \pm 300$ radiocarbon yr B.P. (W-2375)(Schmoll and others, 1972) and represents the Tanya (last) stade of the Naptowne glaciation (Schmoll and Yehle, 1983, 1986; Schmoll and others, 1984). Therefore, the oldest moraines of local derivation in the Allison-Sawmill Creeks area represent the end of late Wisconsin glaciation in the Port Valdez area, and upvalley moraines that record the next younger advance or significant still-stand in these valleys are almost certainly Holocene in age (fig. 1).

\section{Relation Between Local Glaciation and Liscum Slide}

Spatial relations between Liscum slide and the east lateral moraine of the Allison Creek drainage are evidence for a temporal relationship between local glacial events and that massive rock failure. The main body of the slide (rock slides 1 and 2 in fig. 1) was apparently emplaced prior to the 12,000-radiocarbon-yr readvance out of Allison Creek canyon because the undisturbed east lateral moraine fills a large indentation in the slide at the southeastern corner of the TAPS terminal. The first stage of rock sliding was probably caused by loss of support after retreat of the trunk glacier that undercut but also buttressed the steep rock wall south of Port Valdez. Subsequent failures may have been triggered by strong earthquakes. These failures were facilitated by the welldeveloped, planar foliation, which dips steeply northward (Updike and Ulery, 1987).

The third, smaller failure of the steep western rock wall at the head of the slide probably occurred after the 12,000-radiocarbon-yr advance because the east lateral moraine in the canyon of Allison Creek trends into space occupied by the rock wall before it dropped onto the upper part of rock slide 2 (fig. 1). The jagged rocky ridgecrest in this area indicates that glacial ice did not flow through the gap. However, available evidence does not rule out collapse of the rock wall from beneath the glacier at a time when glacier thickness and activity did not permit significant ice flow into the gap.

\section{Deglaciation of Port Valdez}

Based on the results of a sparker survey of the sediment fill in Port Valdez and estimating a yearly sediment influx between $34 \times 10^{9}$ and $65 \times 10^{9}$ metric tons, von Huene and others (1967) concluded that Port Valdez was deglaciated between 3,900 and 9,800 y.a. with a mean of 7,000 y.a. Williams and Coulter (1981) reported a conventional radiocarbon date of 9,520 $\pm 350 \mathrm{yr}$ B.P. (W-1654) for a freshwater-peat sample recovered from an interval between 15.9 and $16.2 \mathrm{~m}$ below sea level in a borehole through the eastern margin of Mineral Creek fan on the northern shore of Port Valdez. In the borehole, this peat is present above a 13.8-m-thick unit of interbedded till and marine silt and gravel deposited during the late Wisconsin glaciation. Therefore, their 9,520-radiocarbon-yr date represents a minimum date for deglaciation of Port Valdez.

Clearly, the trunk glacier formerly occupying Port Valdez was gone before 12,000 radiocarbon y.a. In fact, many areas that were glaciated in late Wisconsinan time in southcentral Alaska were free of ice well before this time (table 2). Comparison with the Cook Inlet trough, where more evidence is preserved, indicates that the major deglaciation of Port Valdez coincided with the waning phase of the Skilak stade of the Naptowne glaciation (Karlstrom, 1964). Unpublished work by my colleagues and me demonstrates that the Skilak stade dates between 14,000 and 16,000 y.a. Therefore, Port Valdez was probably initially cleared of glacial ice about 14,000 y.a.

\section{ACKNOWLEDGMENTS}

I thank Michael C. Metz, formerly of the Geotechnical Department of Alyeska Pipeline Service Company, who graciously granted permission to collect radiocarbon samples from the Swan Lake section and who encouraged publication of the results over the intervening years. Thanks also to Bud Burke and Steve Wilber for many thought-provoking discussions at the exposures and in the pits during our recent search for evidence of the glacial history of Port Valdez. Radiocarbon analyses were conducted at DGGS expense by Geochron Laboratories Division of Krueger Enterprises, Inc., L. David Carter (USGS), and Jeffrey T. Kline(DGGS) reviewed this paper and offered several constructive comments that improved it. I greatly appreciate their input. 


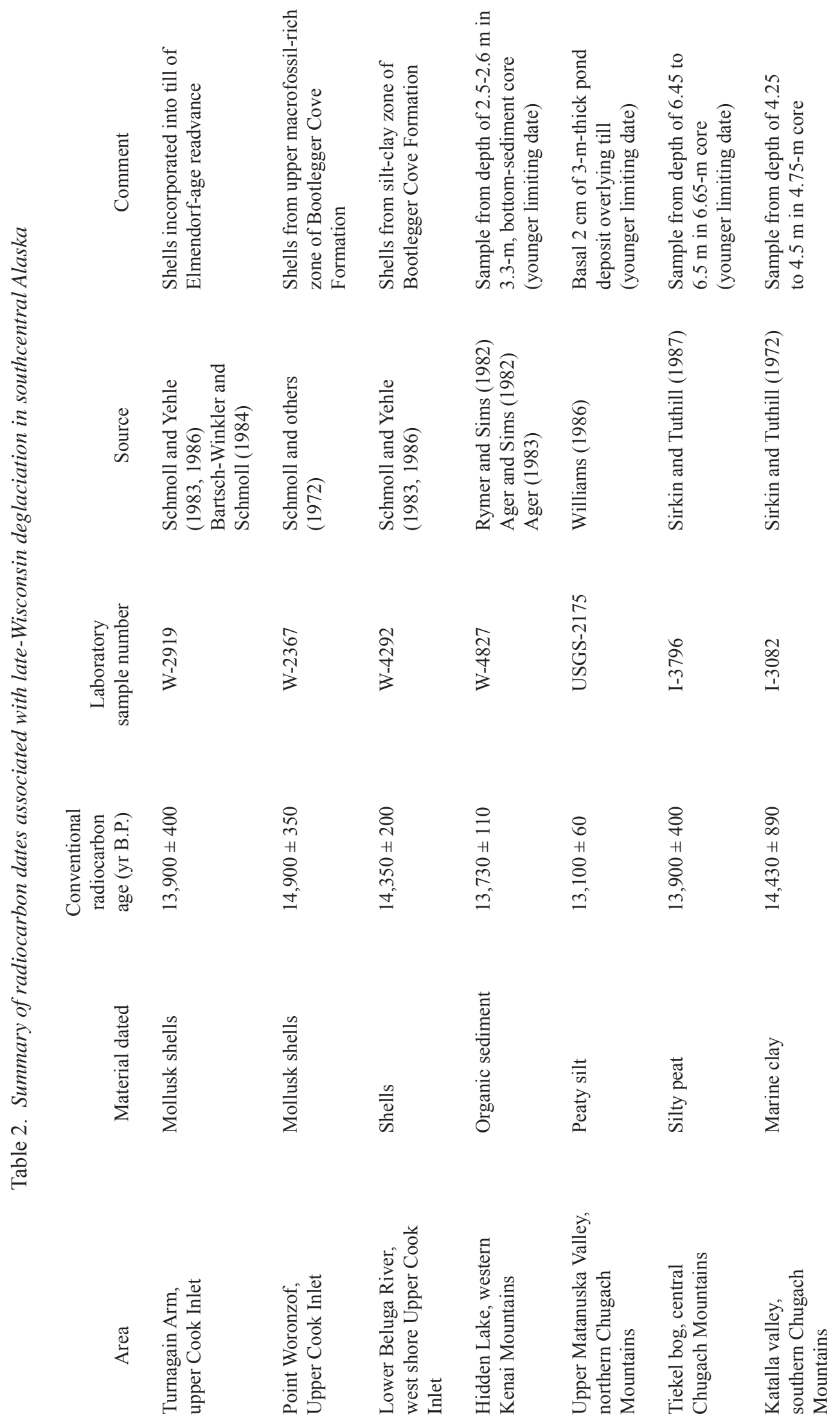




\section{REFERENCES}

Ager, T.A., 1983, Holocene vegatational history ofAlaska, in Wright, H.E., ed., Late-Quaternary environments of the United States, Volume 2, The Holocene: Minneapolis, University of Minnesota Press, p. 128-141.

Ager, T.A., and Sims, J.D., 1982, Late Quaternary pollen record from Hidden Lake, Kenai Peninsula, Alaska: Palynology, v. 6, p. 271-272.

Bartsch-Winkler, Susan, and Schmoll, H.R., 1984, Guide to late Pleistocene and Holocene deposits of Turnagain Arm: Anchorage, Alaska Geological Society guidebook, $70 \mathrm{p}$.

Combellick, R.A., 1987, Surficial and engineering geology of the Valdez area, Alaska, in Combellick, R.A., and Updike, R.G., eds., Geologic studies of critical areas: Valdez, Alaska: Alaska Division of Geological and Geophysical Surveys Public-data File 87-29, 60 p., scale 1:25,000, 2 sheets.

Karlstrom, T.N.V., 1964, Quaternary geology of the Kenai Lowland and glacial history of the Cook Inlet region, Alaska: U.S. Geological Survey Professional Paper 443, $69 \mathrm{p}$.

Lethcoe, N.R., 1987, Glaciers of Prince William Sound, Alaska: Valdez, Prince William Sound Books, 151 p.

Mann, D.H., 1986, Wisconsin and Holocene glaciation of Southeast Alaska, in Hamilton, T.D., Reed, K.M., and Thorson, R.M., eds. Glaciation in Alaska: The geologic record: Anchorage, Alaska Geological Society, p. 237-265.

Rymer, M.J., and Sims, J.D., 1982, Lake-sediment evidence for the date of deglaciation of the Hidden Lake area, Kenai Peninsula, Alaska: Geology, v. 10, no. 6, p. 314-316.

Schmoll, H.R., Szabo, B.J., Rubin, Meyer, and Dobrovolny, Ernest, 1972, Radiometric dating of marine shells from the Bootlegger Cove Clay, Anchorage area, Alaska: Geological Society of America Bulletin, v. 83, no. 4, p. 1107-1114.

Schmoll, H.R., and Yehle, L.A., 1983, Glaciation in the upper Cook Inlet basin: A preliminary reexamination based on geologic mapping in progress, in Thorson, R.M., and Hamilton, T.D., eds., Glaciation in Alaska: Extended abstracts from a workshop: University of Alaska Museum Occasional Paper 2, p. 75-100.

1986, Pleistocene glaciation of the upper Cook Inlet basin, in Hamilton, T.D., Reed, K.M., and Thorson, R.M., eds., Glaciation in Alaska-the geologic record: Anchorage, Alaska Geological Society, p. 193-218.
Schmoll, H.R., Yehle, L.A., Gardner, C.A., and Odum, J.K., 1984, Guide to surficial geology and glacial stratigraphy in the upper Cook Inlet basin: Anchorage, Alaska Geological Society guidebook, 89 p.

Sirkin, L.A., and Tuthill, S.J., 1972, Late Pleistocene palynology and stratigraphy of Controller Bay region, Gulf of Alaska, in Ters, M., ed., Etudes sur le Quaternaire dans le Monde: International Quaternary Association Congress, 8th, Paris 1969, v. 1, p. 197-208.

1987, Late Pleistocene and Holocene deglaciation and environments of the southern Chugach Mountains, Alaska: Geological Society of America Bulletin, v. 99, no. 3, p. 376-384.

Updike, R.G., and Ulery, C.A., 1987, Bedrock geology of the Valdez area, Alaska, in Combellick, R.A., and Updike, R.G., eds., Geologic studies of critical areas: Valdez, Alaska: Alaska Division of Geological and Geophysical Surveys Public-data File 87-29, 60 p., scale 1:25,000, 2 sheets.

von Huene, Roland, Shor, G.G., Jr., and Reimnitz, Erk, 1967, Geological interpretatrion of seismic profiles in Prince William Sound, Alaska: Geological Society of America Bulletin, v. 78, no. 2, p. 259-268.

Williams, J.R., 1986, New radiocarbon dates from the Matanuska Glacier bog section, in Bartsch-Winkler, Susan, and Reed, K.M., eds., Geologic studies in Alaska by the U.S. Geological Survey during 1985: U.S. Geological Survey Circular 978, p. 85-88.

Williams, J.R., and Coulter, H.W., 1981, Deglaciation and sea-level fluctuations in Port Valdez, Alaska, in Albert, N.R.D., and Hudson, Travis, eds., The United States Geological Survey in Alaska: Accomplishments during 1979: U.S. Geological Survey Circular 823-B, p. B78-B80.

Williams, J.R., and Johnson, K.M., 1980, Map and description of late Tertiary and Quaternary deposits, Valdez Quadrangle, Alaska: U.S. Geological Survey Open-file Report 80-892C, scale 1:250,000, 2 sheets. 



\title{
DATING HOLOCENE MORAINES OF CANWELL GLACIER, DELTA RIVER VALLEY, CENTRAL ALASKA RANGE
}

\author{
By \\ Richard D. Reger ${ }^{1}$ and Troy L. Péwé
}

\section{INTRODUCTION}

Canwell Glacier is a 24-km-long valley glacier that terminates just east of Richardson Highway in Delta River valley of the central Alaska Range (fig. 1) (Denton, 1975). Attempts during the past $39 \mathrm{yr}$ to establish ages of the two Holocene moraines of Canwell Glacier have yielded inconsistent results, which are partially resolved by new radiocarbon evidence. The purposes of this report are to document and discuss evidence of the ages of these moraines.

\section{SETTING}

The study area is in the middle Delta River valley near Mile 215, Richardson Highway, about $40 \mathrm{~km}$ northnorthwest of Paxson and about $23 \mathrm{~km}$ north of Isabel Pass. The valley floor, at $2,500 \mathrm{ft}(758 \mathrm{~m})$ elevation, is about $3,000 \mathrm{ft}(909 \mathrm{~m})$ below surrounding glacier-modified peaks. Canwell Glacier is the southernmost of three valley glaciers, including Fels and Castner Glaciers, that approach Richardson Highway from the east (fig. 1).

Canwell Glacier flows west-northwest down the ice-scoured, linear trench of the lengthy Denali fault system (Péwé and Reger, 1983, 1989). Upper and Lower Miller Creeks are glacial-meltwater streams that drain short distances west and northwest, respectively, from Canwell Glacier into Delta River, which is extensively braided in this reach. The terminus of Canwell Glacier at 2,650 $\mathrm{ft}(803 \mathrm{~m})$ elevation consists of extensive icecored ablation moraine, indicating that near-terminus ice is stagnant (Mendenhall, 1900).

More extensive former positions of Canwell Glacier are documented by two Holocene moraines (fig. 1). The older, outer moraine is discontinuous, has low relief, and apparently contains no ice core. Above treeline along the southern side of Canwell Glacier, a well-preserved, tundra-covered till ridge represents a lateral moraine of the older Holocene advance (Reger, 1964; Reger and Péwé, 1969). A small remnant of the equivalent terminal moraine is preserved near the highway bridge over Up-

\footnotetext{
${ }^{1}$ Alaska Division of Geological and Geophysical Surveys, 794 University Avenue, Suite 200, Fairbanks, Alaska 99709-3645.

${ }^{2}$ Department of Geology, Arizona State University, Tempe, Arizona 85287.
}

per Miller Creek. This short till ridge is forested by old spruce and bears a continuous, mossy ground cover up to $0.3 \mathrm{~m}$ thick. The younger, inner moraine of Canwell Glacier is continuous, fresh looking, and stands in relief as high as $4.6 \mathrm{~m}$. It is composed of unweathered rock debris and contains an extensive ice core, especially at higher elevations. The gravelly morainal surface supports scattered spruce and aspen trees, willow shrubs, and a thin, discontinuous ground turf.

Based on a study of 1:63,360-scale infrared aerial photographs (ALK 60 CIR, negatives 3895-3896) taken August 24, 1981, modern altitudinal limit of spruce trees in the vicinity of the terminus of Canwell Glacier is close to $2,750 \mathrm{ft}(833 \mathrm{~m})$ elevation, about $250 \mathrm{ft}$ (76 m) above the floor of Delta River valley. Other treeline species include aspen and balsam poplar.

\section{EVIDENCE OF MORAINAL AGES}

Dendrochronologic, lichenometric, and radiocarbon methods have been used to date moraines of Canwell Glacier. Initial tree-ring counts supplemented by one radiocarbon date were later tested by lichenometric dating, yielding controversial results (Reger, 1964; Péwé, 1965; Reger and Péwé, 1969; Péwé and Reger, 1983, 1989). Radiocarbon samples recently collected and analyzed aid interpretation of previous results.

\section{Older Holocene Moraine}

In 1951, in the western terminal zone of Canwell Glacier, Péwé counted as many as 165 annual growth rings in stumps of sound, first-generation spruce trees that were cut an estimated 10 to $15 \mathrm{yr}$ earlier and estimated ages of rotten-centered spruce trees as old as $250 \mathrm{yr}$ (fig. 2) (Péwé, 1957). In 1952, he collected a 15-cm-diameter spruce log from beneath what he interpreted to be till of the older Holocene advance and obtained a radiocarbon age of less than 200 yr B.P. (W-268) for this wood (Rubin and Suess, 1956) (fig. 2 and table 1, sample A). However, Rubin (written commun., 1964) stressed that the wood could also be older than $200 \mathrm{yr}$, and a piece of the same log was later dated at $310 \pm 75$ radiocarbon yr B.P. (GX-10982) (fig. 2 and table 1, sample E). To allow for significant variation in atmospheric-radiocarbon content during Holocene time (Stuiver and others, 1991), 


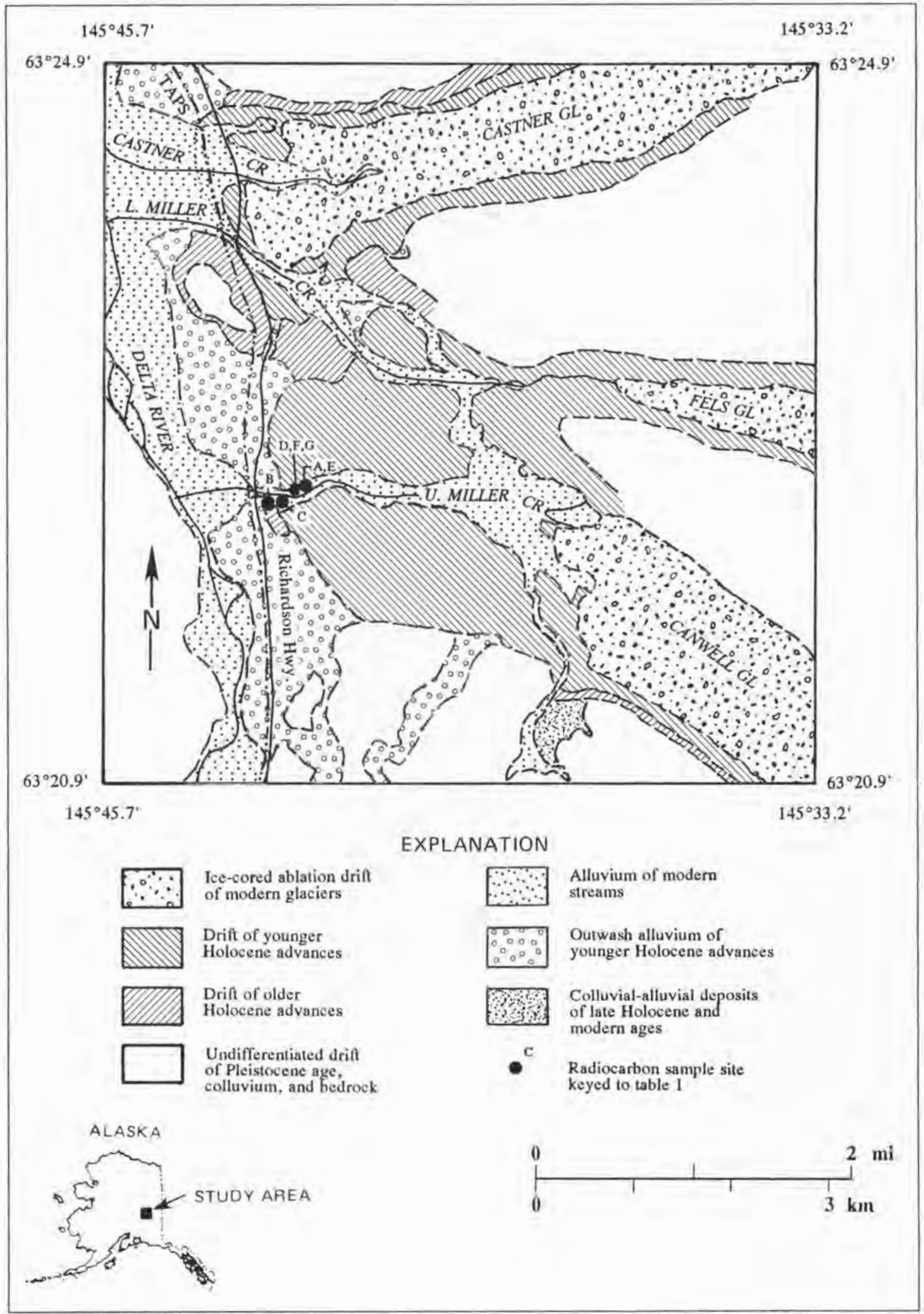

Figure 1. Geologic map showing radiocarbon sampling sites associated with Holocene moraines of Canwell Glacier relative to Richardson Highway and trans-Alaska pipeline route (TAPS). Base is 1:63,360-scale infrared aerial photograph ALK 60, negative 3895, taken August 24, 1981. 


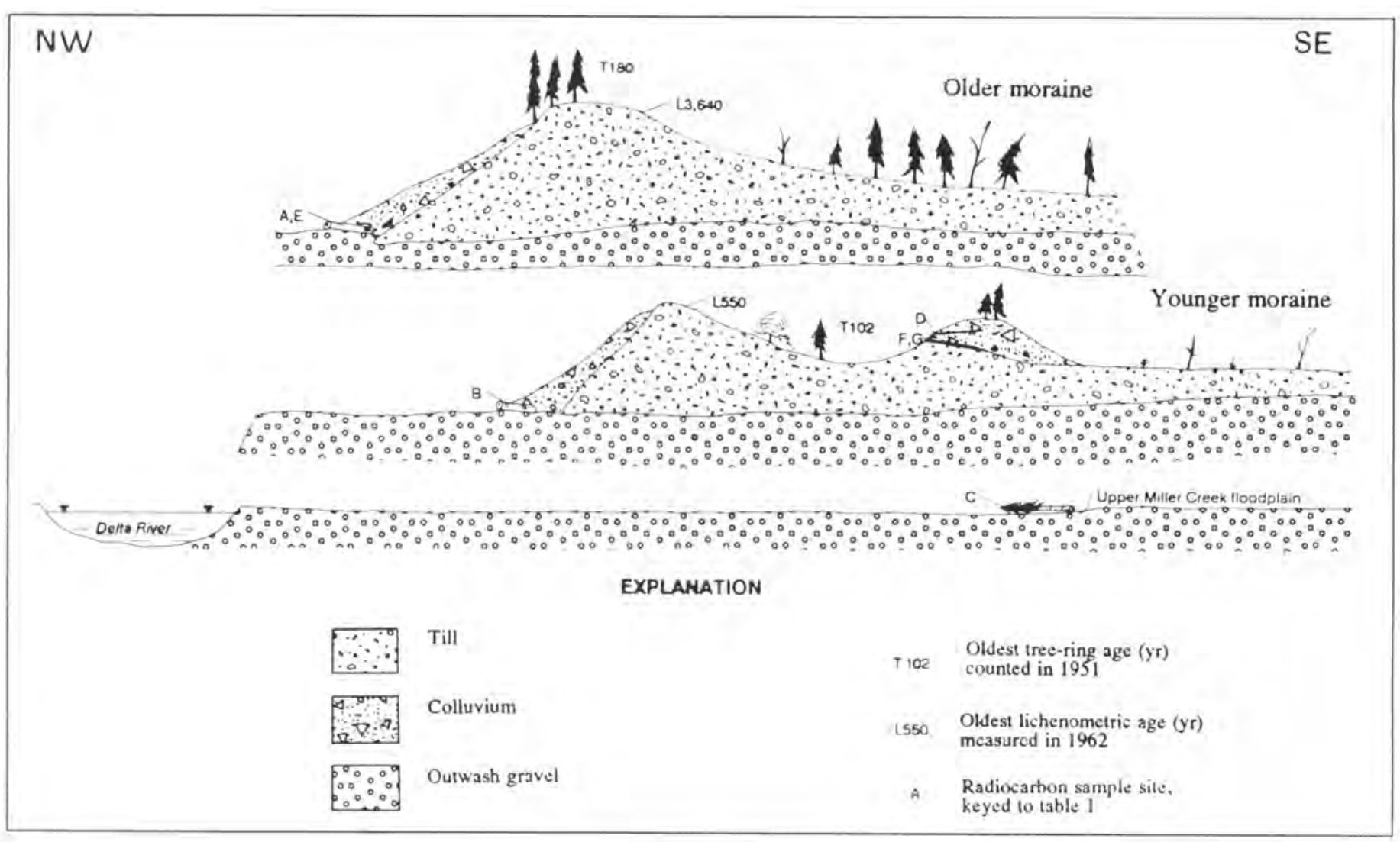

Figure 2. Exploded composite projection showing relations of Holocene features in terminal area of Canwell Glacier to treering, lichen, and radiocarbon ages, keyed to table 1. Vegetation shown diagrammatically.

these conventional radiocarbon ages were calibrated to tree-ring ages ranging from modern (table 1, sample A) to as old as $482 \mathrm{yr}$ B.P. (table 1, sample E). Because sample A was analyzed at a time when test results were less reliable than now, we believe that sample E, which has a mean calibrated age of 316 to 421 yr B.P., better represents the age of the wood collected by Péwé.

The dense vegetation cover on the remnant of the older terminal moraine is not favorable for lichenometry. However, Reger (1964) measured largest thalli of the crustose lichen Rhizocarpon geographicum (s.l.) above treeline on the equivalent south lateral moraine of Canwell Glacier. There, among a sample population of the 75 largest plants at eight stations, maximum diameters ranged from 132 to $161 \mathrm{~mm}$, and maximum diameters (between stations) averaged $144 \mathrm{~mm}$. Reger's initial growth curve for $R$. geographicum (s.l.) was based on dendrochronological ages of the Holocene moraines of Black Rapids and Canwell Glaciers and was very different from the growth curve for this species developed in the St. Elias Mountains by Denton and Karlén (1973, 1977). Recent, as yet unpublished results by Ten Brink and his associates along the northern flank of the Alaska Range essentially duplicate the Denton-Karlén curve (Péwé and Reger, 1983). Assuming that the Denton-Karlén curve is a reasonably accurate growth curve for $R$. geographicum (s.l.) in Delta River valley, the single largest lichen measured on the older south lateral moraine of Canwell Glacier $(161 \mathrm{~mm})$ indicates that at least 3,640 yr have passed since moraine stabilization; based on the average maximum diameter among the population surveyed $(144 \mathrm{~mm})$, the south lateral moraine of Canwell Glacier is at least $3,330 \mathrm{yr}$ old.

\section{Younger Holocene Moraine}

In 1951, Péwé counted up to 102 annual growth rings in the largest spruce trees growing on the younger terminal moraine of Canwell Glacier (Reger and Péwé, 1969). In 1961, Reger (1964) measured diameters of largest $R$. geographicum (s.1.) above treeline on the equivalent south lateral moraine. Among the 74 largest individuals at eight stations along the crest of the moraine, diameters varied from 28 to $50 \mathrm{~mm}$ and maximum diameters (between stations) averaged $34 \mathrm{~mm}$. At six stations on the coeval terminal moraine, where trees and shrubs promote an 
Table 1. Summary of radiocarbon dates associated with Holocene features in terminal area of Canwell Glacier, keyed to figure 2. All samples but W-268 corrected for natural isotopic fractionation based on carbon-13 content. Calibration to calender years B.P. based on changes in radiocarbon contents of dendrochronologically dated tree rings (Stuiver, 1982; Stuiver and Pearson, 1986; Stuiver and Reimer, 1986)

\begin{tabular}{|c|c|c|c|c|c|}
\hline Sample & Materials dated & $\begin{array}{l}\text { Radiocarbon } \\
\text { age (yr B.P.) }\end{array}$ & $\begin{array}{l}\text { Calibrated age } \\
\text { (yr B.P.) } \\
1 \text { min. } \\
\text { (cal. mean age) } \\
1 \text { max. }\end{array}$ & $\begin{array}{l}\text { Laboratory } \\
\text { number }\end{array}$ & Source \\
\hline A & Spruce wood & $200 \pm$ & $\begin{array}{l}0^{*}(0 *, 1,162 \\
166,285) 289\end{array}$ & $\mathrm{~W}-268$ & $\begin{array}{l}\text { Péwé (1957), } \\
\text { Péwé and } \\
\text { Reger (1983) }\end{array}$ \\
\hline B & Spruce wood & $200 \pm 75$ & $\begin{array}{l}0^{*}\left(0^{*}, 1,162\right. \\
166,285) 307\end{array}$ & GX-10983 & This study \\
\hline $\mathrm{C}$ & Spruce wood & $200 \pm 75$ & $\begin{array}{l}0^{*}\left(0^{*}, 1,162\right. \\
166,285) 307\end{array}$ & GX-14441 & This study \\
\hline $\mathrm{D}$ & $\begin{array}{l}\text { Bark, leaves, } \\
\text { and disseminated } \\
\text { organics }\end{array}$ & $225 \pm 90$ & $0 *(293) 423$ & GX-15535 & This study \\
\hline $\mathrm{E}$ & Same as sample A & $310 \pm 75$ & $\begin{array}{l}296(316,394 \\
421) 482\end{array}$ & GX-10982 & This study \\
\hline $\mathrm{F}$ & $\begin{array}{l}\text { Organics in com- } \\
\text { pressed paleosol } \\
\text { A horizon }\end{array}$ & $675 \pm 130$ & $540(667) 730$ & GX-14440 & This study \\
\hline G & Same as sample F & $905 \pm 90$ & $\begin{array}{l}728(795,813,820 \\
871,877) 946\end{array}$ & GX-15534 & This study \\
\hline
\end{tabular}

$\overline{0^{*}=\text { negative }}$ calibrated age B.P. (post-1950).

irregular, spotty lichen cover and lichen dating is less reliable, 13 of the largest thalli varied from 18 to 33 $\mathrm{mm}$ in diameter and averaged $26 \mathrm{~mm}$. Assuming that the largest single lichen measured on the south lateral moraine above treeline $(50 \mathrm{~mm})$ most accurately reflects the minimum age of the younger Holocene moraine, it is about 550 yr old (fig. 2) (Péwé and Reger, 1983). Based on the Denton-Karlén growth curve for $R$. geographicum (s.1.), the average maximum thalli diameter on the moraine above treeline $(34 \mathrm{~mm})$ indicates that the moraine is at least $230 \mathrm{yr}$ old. An 8-cm-diameter spruce log collected by Péwé in 1952 from beneath what he interpreted to be 
till of the younger Holocene moraine was later dated at $200 \pm 75$ radiocarbon yr B.P. (GX-10983) (fig. 2 and table 1 , sample B). The mean calibrated age of wood sample B ranges from modern to $285 \mathrm{yr}$ B.P., and the sample may be as old as 307 calibrated yr B.P. (table 1).

Recent excavations by Reger in the north bank of upper Miller Creek, where it cuts through this moraine, uncovered two buried, thin organic layers overlying till of the younger Holocene advance. Well-preserved leaves, delicate twigs, and moss in these layers indicate that both layers were buried by colluvial diamicton derived from nearby till. The upper organic layer was covered by 1.5 m of gravelly colluvium and was separated from the lower organic layer by $1.2 \mathrm{~m}$ of gravelly colluvium. Both layers dipped north about $35^{\circ}$ (fig. 2). The upper layer, which was about $2 \mathrm{~mm}$ thick where exposed beneath a large (0.4- by $1.1-\mathrm{m})$ boulder, dated $225 \pm 90$ radiocarbon yr B.P. (GX-15535) (fig. 2 and table 1, sample D). Sample D has a mean calibrated age of 293 yr B.P., but it could date from modern to 423 calibrated yr B.P. (table 1). The 2- to 15-mm-thick, lower organic layer capped a 14-cmthick B horizon that was light olive brown (2.5Y5/4); the underlying unweathered gravelly till was olive gray $(5 Y 5 / 2)$. Two dates were obtained for the lower organic layer: $675 \pm 130$ radiocarbon yr B.P. (GX-14440) and $905 \pm 90$ radiocarbon yr B.P. (GX-15534) (fig. 2 and table 1, samples F and G). When calibrated separately, samples $F$ and $G$ have mean ages ranging from 667 to 877 yr B.P. (table 1). The calibrated weighted average of both samples is $735 \mathrm{yr}$ B.P., which is a minimum date for the older Holocene moraine.

\section{IMPLICATIONS}

Data on the ages of Holocene moraines of Canwell Glacier provide insights into problems applying dendrochronology, lichenometry, and radiocarbon-dating techniques in this near-alpine area. Spruce trees growing on younger and older Holocene terminal moraines are obviously much younger than the surfaces they inhabit. Factors possibly contributing to this age difference include: (1) severity of near-alpine conditions of cool summer temperatures, strong winds, and slowly melting glacial-ice cores in moraines; (2) shifting treeline; (3) severe insect infestations; and (4) repeated wildfires
(Péwé and Reger, 1983, 1989). Comparison of the results of different techniques for dating the younger Holocene moraine of Canwell Glacier demonstrates that an age estimate based on the maximum size of the largest lichens growing on this moraine more closely approximates its actual age than the ages of trees growing on it. However, lichenometric ages still represent minimum values because lichen colonization and early growth are slow, and several decades may pass before a uniform rate of diameter increase is sustained (Reger and Péwé, 1969). Radiocarbon dates require special care in their interpretation. Initial assumptions that spruce trees buried by gravelly diamicton are components of forest beds overridden by two Holocene advances of Canwell Glacier were erroneous. Clearly, these samples were buried by younger colluvium derived from local tills (fig. 2, samples A, B, and E). Heartwood of a dead but otherwise unmodified mature spruce tree lying on the modern floodplain of Upper Miller Creek (fig. 2 and table 1, sample C) produced the same radiocarbon age as wood supposedly overridden by the younger Holocene glacial advance. Also, modern trees growing along the tops of eroding, steep, floodplain-marginal banks of till are soon toppled by undercutting and quickly inundated by debris flows.

In the northwestern terminal zone of Canwell Glacier, the older Holocene moraine joins coeval terminal moraines of Fels and Castner Glaciers (fig. 1). Morainal distribution indicates that these three glaciers formed a compound terminal ice mass that may have blocked Delta River, at least temporarily, during the Neoglacial ice expansion that has been documented elsewhere in the Alaska Range(Ten Brink, 1983; Calkin, 1988). Morainal distribution indicates that Canwell and Fels Glaciers joined again during the younger Holocene advance but remained separate from Castner Glacier.

\section{ACKNOWLEDGMENTS}

We are grateful to Alfred G. Sturmann for able assistance in the field and for cartographic support. L. David Carter (USGS) and Rodney A. Combellick (DGGS) provided technical reviews of this paper. Rod was especially helpful in calibrating the conventional radiocarbon dates. 


\section{REFERENCES}

Calkin, P.E., 1988, Holocene glaciation of Alaska (and adjoining Yukon Territory, Canada): Quaternary Science Reviews, v. 7, no. 2, p. 159-184.

Denton, G.H., 1975, Alaska Range, in Field, W.O., ed., Mountain glaciers of the northern hemisphere: Hanover, U.S. Army Cold Regions Research and Engineering Laboratory, v. 2, p. 573-620.

Denton, G.H., and Karlén, Wibjorn, 1973, Lichenometry: Its application to Holocene moraine studies in southern Alaska and Swedish Lapland: Arctic and Alpine Research, v. 5, no. 4, 347-372.

1977 , Holocene glacial and tree-line variations in the White River valley and Skolai Pass, Alaska and Yukon Territory: Quaternary Research, v. 7, no. 1, p. 63-111.

Mendenhall, W.C., 1900, A reconnaissance from Resurrection Bay to the Tanana River, Alaska, in 1898: U.S. Geological Survey 20th Annual Report, pt. 7, p. $265-340$.

Péwé, T.L., 1957, Recent history of Canwell and Castner Glaciers, Alaska [abs.]: Geological Society of America Bulletin, v. 68, no. 12, pt. 2, p. 1779.

1965, Delta River area, Alaska Range, in Péwé, T.L., Ferrians, O.J., Jr., Nichols, D.R., and Karlstrom, T.N.V., Guidebook for Field Conference F, central and south-central Alaska, International Association for Quaternary Research, 7th Congress, Fairbanks, 1965: Lincoln, Nebraska Academy of Sciences, p. 55-93 (reprinted 1977, College, Alaska Division of Geological and Geophysical Surveys).

Péwé, T.L., and Reger, R.D., 1983, Delta River area, Alaska Range, in Péwé, T.L., and Reger, R.D., eds., Guidebook to permafrost and Quaternary geology along the Richardson and Glenn Highways between Fairbanks and Anchorage, Alaska: Alaska Division of Geological and Geophysical Surveys Guidebook 1, p. 47-135.
1989, Delta River area, Alaska Range, in Péwé, T.L., and Reger, R.D., eds., Quaternary geology and permafrost along the Richardson and Glenn Highways between Fairbanks and Anchorage, Alaska: Washington, American Geophysical Union Guidebook T102, p. 25-38.

Reger, R.D., 1964, Recent glacial history of Gulkana and College Glaciers, central Alaska Range, Alaska: Fairbanks, University of Alaska M.S. thesis, 75 p.

Reger, R.D., and Péwé, T.L., 1969, Lichenometric dating in the central Alaska Range, in Péwé, T.L., ed., The periglacial environment, past and present: Montreal, McGill-Queens University Press, p. 223-247.

Rubin, M., and Suess, H.E., 1956, U.S. Geological Survey radiocarbon dates III: Science, v. 123, no. 3194, p. 442-448.

Stuiver, Minze, 1982, A high-precision calibration of the AD radiocarbon time scale: Radiocarbon, v. 24, no. 1, p. 1-26.

Stuiver, Minze, Braziunas, T.F., Becker, Bernd, and Kromer, Bernd, 1991, Climatic, solar, oceanic, and geomagnetic influences on late-glacial and Holocene atmospheric ${ }^{14} \mathrm{C} /{ }^{12} \mathrm{C}$ change: Quaternary Research, v. 35 , no. 1 , p. $1-24$.

Stuiver, Minze, and Pearson, G.W., 1986, High-precision calibration of the radiocarbon time scale, AD 1950500 BC: Radiocarbon, v. 28, no. 2B, p. 805-838.

Stuiver, Minze, and Reimer, P.J., 1986, A computer program for radiocarbon age calibration: Radiocarbon, v. 28, p. 1022-1030.

Ten Brink, N.W., 1983, Glaciation of the northern Alaska Range, in Thorson, R.M., and Hamilton, T.D., eds., Glaciation in Alaska: Extended abstracts from a workshop: University of Alaska Museum Occasional Paper 2, p. 82-91. 


\title{
GILEAD SANDSTONE, NORTHEASTERN BROOKS RANGE, ALASKA: AN ALBIAN TO CENOMANIAN MARINE CLASTIC SUCCESSION
}

\author{
By \\ Rocky R. Reifenstuhl'
}

\section{INTRODUCTION}

The Gilead sandstone (an informal name used in this report) of Albian to Cenomanian age is a succession of sandstone, siltstone, and lesser shale that crops out in the Gilead Creek-Ivishak River area along the Shaviovik front of the northeastern Brooks Range in the Sagavanirtok A-2 Quadrangle, northeastern Alaska (fig. 1). A detailed geologic map (Pessel and others, in prep.) and two measured sections (930 $\mathrm{m}$ and $254 \mathrm{~m}$ thick) indicate that the rocks are part of a faulted, broad, southwest-plunging syncline that probably is in thrust-fault relation with the underlying Kingak Shale of Jurassic and Cretaceous age (fig. 2). Previously, the Gilead sandstone was mapped as the lower member of the Ignek Formation (Keller and others, 1961).

Age of the Gilead sandstone is early Cenomanian to early late Cenomanian and Albian (W.P. Elder, written commun., 1990), and it correlates with the Nanushuk Group of Albian to Cenomanian age. This correlation extends to the northeast the known distribution of rocks of late Albian and early Cenomanian age in northeastern Alaska.

This paper presents detailed paleontologic, lithologic, and field data on this little understood and poorly defined belt of rocks.

\section{PREVIOUS STUDIES AND STRATI- GRAPHIC NOMENCLATURE}

Leffingwell (1919) originally defined the Ignek Formation as "2,500 ft of black shales with coal or 'red beds' and subordinate sandstone members that probably overlies the Kingak Shale and occurs at both ends and along the northern front of the Sadlerochit Mountains." Payne and others (1951) mapped these rocks as the Nanushuk and Colville Groups. Gryc and Mangus (1947) and Keller and others (1961) included both Lower and Upper Cretaceous beds in the Ignek Formation. Keller and others (1961) redefined Leffingwell's Ignek Formation to include strata that unconformably overlie the Okpikruak and Kingak Formations and underlie the Sagavanirktok Formation from the Ivishak River to the Canning River and eastward.

${ }^{1}$ Alaska Division of Geological and Geophysical Surveys, 794 University Avenue, Suite 200, Fairbanks, Alaska 99709-3645.

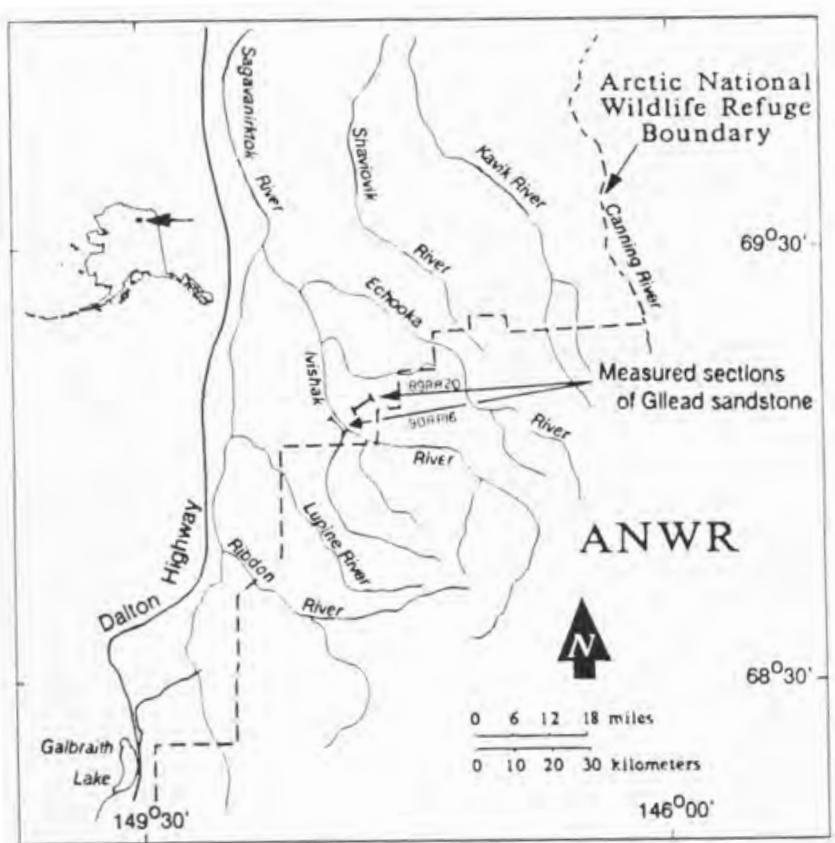

Figure 1. Location of measured sections of Gilead sandstone.

They divided the Ignek Formation into lower and upper members and designated the succession of sandstone and shale at Gilead Creek as part of the "Ignek Formation, lower member." Keller and others (1961) mapped the Gilead Creek area and made the Gilead sandstone the lower member of the Ignek Formation. Their section 8 was measured at the same locality as section 89RR20 of this report, but it extended southeast down the valley of Kashivi Creek to the contact with rocks they mapped as Okpikruak Formation. No fossils were reported in their measured section.

Detterman and others (1975) abandoned the term Ignek Formation because some Ignek rocks closely resemble formations and members of the Nanushuk and Colville Groups in the Umiat area of the eastcentral North Slope. They suggested that the Nanushuk and Colville Groups be extended into northeastern Alaska.

\section{LITHOLOGY AND STRATIGRAPHY}

The Gilead sandstone is characteristically organized into a number of distinctive upward-coarsening cycles that are 39 to $100 \mathrm{~m}$ thick. The well-exposed, 254-m-long 
measured section (90RR16) along the Ivishak River comprises eight coarsening-upward cycles. The discontinuously exposed, 930-m-long measured section (89RR20) between Gilead Creek and Kashivi Creek comprises at least eight coarsening-upward cycles (fig. 3). The internal organization of these 50 - to 120 -m-thick cycles typically consists of a basal, 1 - to 1.5 -m-thick shale overlain by an upward-coarsening succession of thin, parallel-bedded

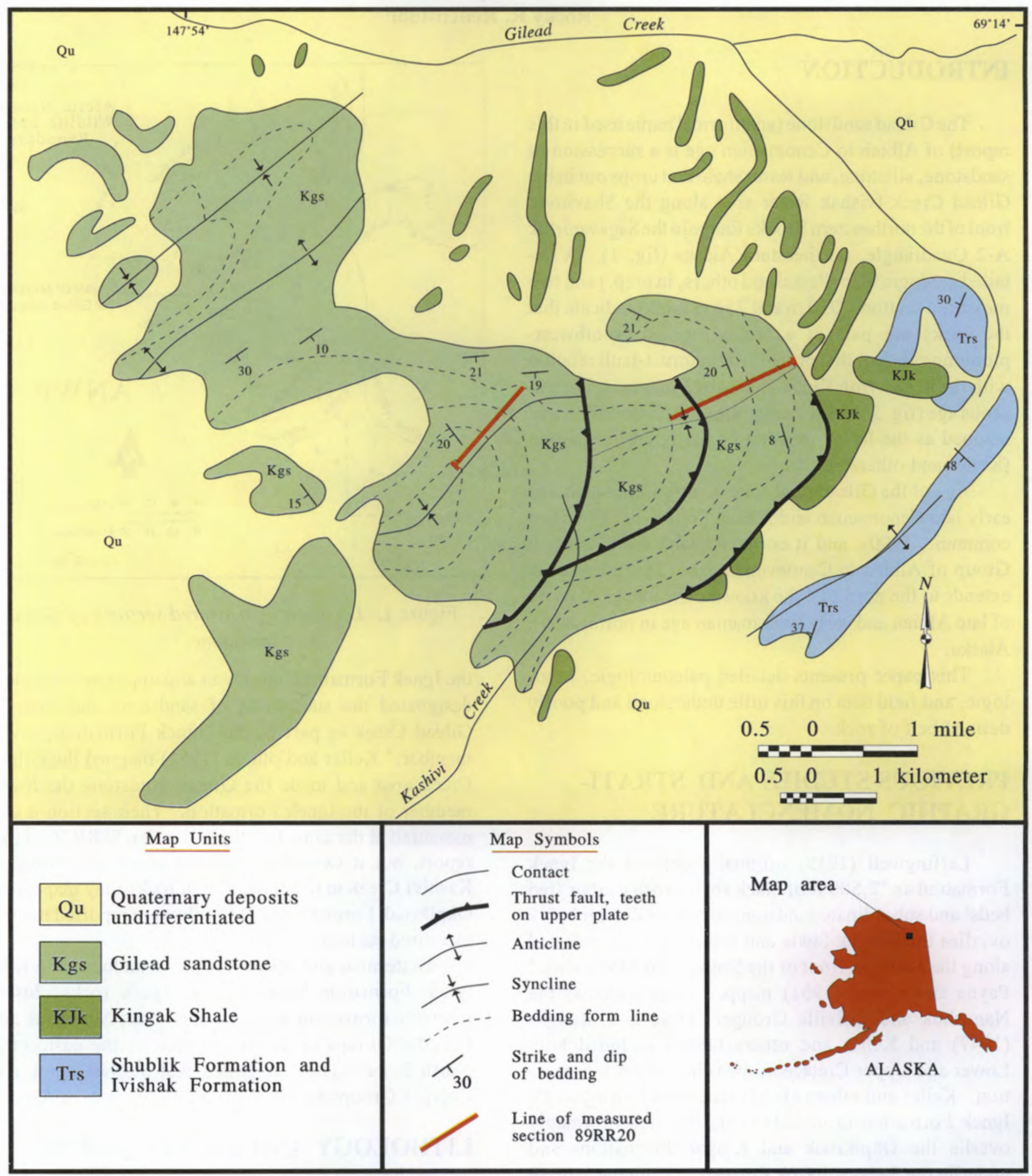

Figure 2. Generalized geologic map of Gilead sandstone in the Gilead-Kashivi Creek area showing location of measured section 89RR20. 
silty shale, siltstone, and very fine-grained sandstone, which is locally ripple laminated. Grain size and bedding thickness increase up-section and sedimentary structures include parallel and ripple lamination, crossbedding, trough crossbedding (0.5- to 1.5 - $\mathrm{m}$ wavelength and 0.1 to 0.3 -m amplitude), hummocky cross-stratification, and minor graded bedding (Bouma Ta, Tab, Tabc, Tac, and Tbc).

The uppermost part of the typical cycle consists of medium- to thick-bedded, medium- and coarse-grained sandstone. Typically, Gilead sandstone beds are medium bedded (1 to $20 \mathrm{~cm}$ ), nonchannelized, or structureless; thick-bedded units ( $>50 \mathrm{~cm}$ thick) of apparently featureless, medium- and coarse-grained sandstone are also common. Load and flute casts are locally common. Locally, 3- to 5-m-wide channels and climbing ripples are present.

The sandstone is typically medium- to dark-gray, fine- to coarse-grained, subangular, moderately sorted litharenite, which weathers dark gray and orange-brown. Petrographic estimates of framework grains are: 50 percent quartz, 30 percent chert, 10 percent metamorphicrock fragments, 2 percent plagioclase feldspar, 2 percent limonitic-weathered clasts, 1 percent white mica, and (locally) 3 percent carbonaceous material. Matrix and cement $(<10$ percent of the rock) are primarily clay, iron oxide, and locally carbonate. Porosity and permeability are estimated to be low in most of the sandstone. Siltstone is a minor component in the unit ( $<5$ percent) and is gradational between the top of sandstone beds and overlying shale horizons. Very dark-gray-to-black shale beds are typically $<5 \mathrm{~cm}$ thick and locally contain carbonaceous plant fragments and carbonaceous material. The sandstone-to-shale ratio is $>10: 1$.

\section{Measured Sections}

The base of section $89 \mathrm{RR} 20$ is at $69^{\circ} 10^{\prime} 23^{\prime \prime} \mathrm{N}$., $147^{\circ} 43^{\prime} 03^{\prime \prime} \mathrm{W}$., and the top of the section is at $69^{\circ} 09^{\prime} 41^{\prime \prime} \mathrm{N}$., $147^{\circ} 48^{\prime} 05^{\prime \prime} \mathrm{W}$. in the Sagavanirktok A-2 Quadrangle (fig. 2). The base of this section, which is rubble covered, is probably in thrust-fault contact with the underlying Kingak Shale (fig. 3; Pessel and others, in prep.). The section traverse extends southwest from the base to the $1,825 \mathrm{ft}(553 \mathrm{~m})$ elevation, where the section is offset $1.6 \mathrm{~km}$ west (center of sec. 21, T. 3 S., R. 18 E., Umiat Meridian) to a ridge at $1,905 \mathrm{ft}(880 \mathrm{~m})$ elevation. From that point the section was measured to the southwest (fig. 2). This offset in the measured section is due to the presence of a north-striking thrust fault. Evidence for this structural discontinuity includes abundant tectonic indicators and apparent duplication of the upper part of the section to the west. Bedding in the faulted syncline

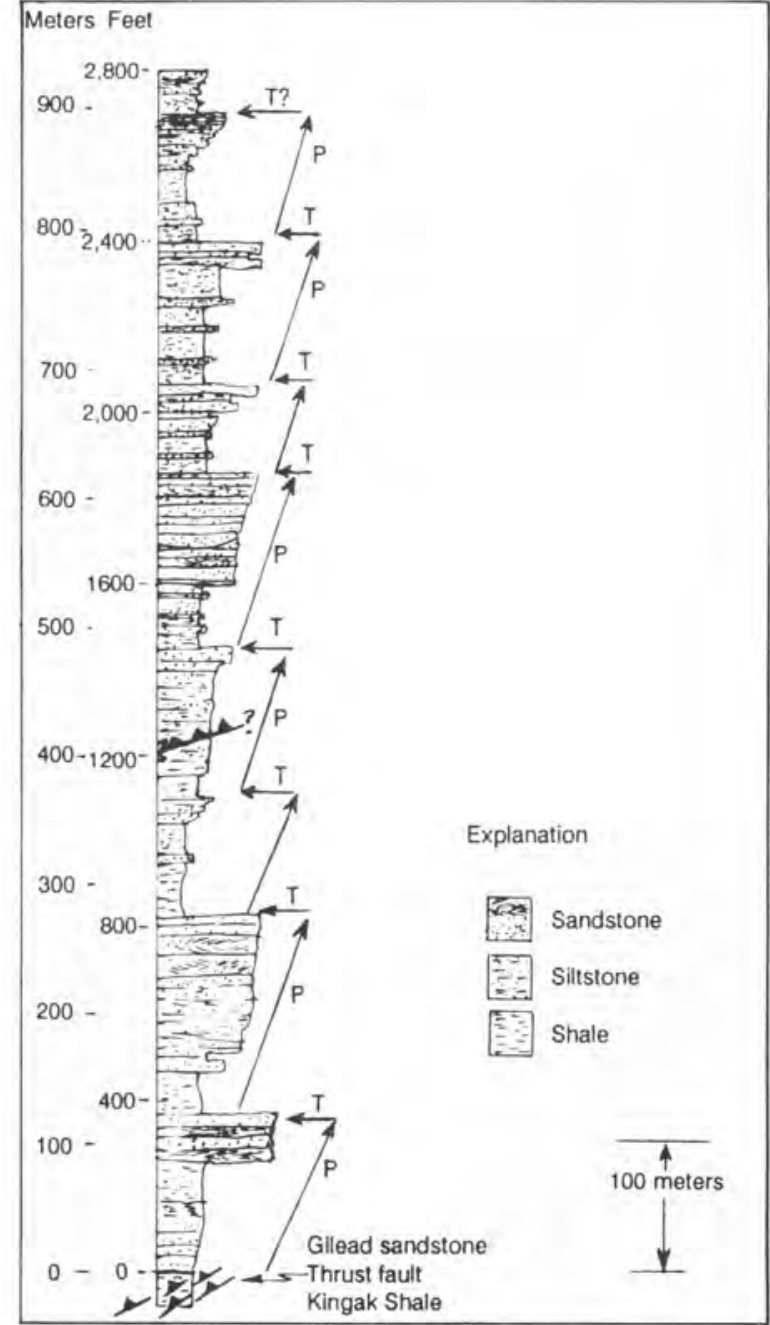

Figure 3. Generalized statigraphic section (89RR20) of the Gilead sandstone; $P$ = progradation, $T=$ transgression.

in the Gilead Creek area typically strikes east and dips from $10^{\circ}$ to $30^{\circ}$ south.

Measured section 90RR16 is $254 \mathrm{~m}$ thick and is located at approximately the $1,000-\mathrm{ft}(300-\mathrm{m})$ elevation along the western bank of Ivishak River. The base of section $90 \mathrm{RR} 16$ is at $69^{\circ} 06^{\prime} 00^{\prime \prime} \mathrm{N}$., $148^{\circ} 02^{\prime} 00^{\prime \prime} \mathrm{W}$., and the top of the section is at $69^{\circ} 06^{\prime} 20^{\prime \prime} \mathrm{N}$., $148^{\circ} 02^{\prime} 20^{\prime \prime} \mathrm{W}$. in the Sagavanirktok A-2 Quadrangle (fig. 1). Bedding in this section typically strikes east and dips from $45^{\circ}$ to $85^{\circ}$ south. This rivercut provides the best exposures of sedimentary structures, lithologic cycles, and postdepositional tectonic structures in the area. Stratigraphic relation between these two measured sections is unknown because there are no distinctive marker beds.

The Gilead sandstone is predominantly medium- to coarse-grained litharenite with lesser siltstone and shale. Coarser grained sandstone is most abundant and is locally 
gradational into finer grained sandstones. Siltstone is a minor component ( $<5$ percent) but may be more abundant in rubble- and vegetation-covered intervals. Siltstone is gradational between the top of sandstone beds and the overlying thin shale horizons. Shale (typically $<5 \mathrm{~cm}$ thick in outcrop) is very dark gray to black and locally contains carbonaceous plant fragments and coal. The sandstone-to-shale ratio is $>10: 1$. Sandstone forms resistant outcrop ridges in the Gilead Creek area, whereas shale-rich sequences underlie recessive-weathering, rubble- and vegetation-covered slopes. Consequently, sandstone appears to be the dominant rock type in outcrop. These ribs of sandstone define the broad, faulted syncline in the Gilead Creek area.

\section{Petrography}

The Gilead sandstone is typically a dark-gray-tomedium-gray-, dark-gray-, and orange-brown-weathering, fine- to coarse-grained, subangular, moderately sorted litharenite. Petrographic estimates on framework grains are: 50 percent quartz, 30 percent chert, 10 percent metamorphic-rock fragments, 2 percent plagioclase feldspar, 2 percent limonitic-weathered clasts, 1 percent white mica, and (locally) 3 percent carbonaceous material.

Matrix and cement in this litharenite consist of $\leq 10$ percent clay and iron oxide, however carbonate cement may locally constitute 10 percent of the rock, where it is preferentially concentrated in broad, troughcrossbedded zones. In one carbonate-rich thin section, chert grains are replaced by microcrystalline carbonate. Porosity and permeability in sandstone are estimated to be low, based on examination of hand specimens and epoxy-filled thin sections.

\section{KingaK SHALE}

Kingak Shale of Jurassic to Neocomian age underlies Gilead sandstone in apparent thrust-fault contact (fig. 2). Quartz crystals up to $1.5 \mathrm{~cm}$ long in open fractures, abundant slickensides, tectonized shale and brecciation at several localities at the top of the Kingak Shale are evidence of faulting there.

Kingak Shale consists of black (unweathered) and orange-brown-weathered, soft clay-shale exposed only locally as rubble crop. Concretions up to $15 \mathrm{~cm}$ in diameter are abundant in float. Iron-stained, very fine-grained sandstone float also is present locally. No megafossils were found in the Kingak Shale during this study. A black-shale sample from the top of the Kingak Shale yielded a single poorly preserved specimen of Pareodinia ceratophora of probable Jurassic age (Bujak and Davies, written commun., 1989). Two additional pollen samples from the Kingak Shale in the Gilead Creek area yield Jurassic and possible Bathonian (Middle Jurassic) ages. Thermal-alteration indices (TAI) in the six samples of Kingak Shale range from $3+$ to 4 - (table 2).

\section{SEDIMENTOLOGY}

Within the Gilead sandstone, groups of individual beds separate naturally into packages that coarsen and thicken up section. These packages range in thickness from $30 \mathrm{~m}$ to as much as $100 \mathrm{~m}$ (fig. 3). Sandstone beds are typically non-channelized and appear structureless. Good exposures exhibit parallel bedding, ripple laminations, crossbedding, and trough cross-stratification. Trough cross-stratifications pinch and swell; they range in thickness from 20 to $50 \mathrm{~cm}$ with individual beds ranging in thickness from 1 to $3 \mathrm{~cm}$. Wavy lamination (possible upper flow regime), hummocky cross-stratification, climbing ripples, and graded bedding are present locally; load and groove casts are locally abundant. Climbing ripples are present in fine to coarse sandstone and typically vary in thickness from 3 to $4 \mathrm{~cm}$, although they are locally as thick as $20 \mathrm{~cm}$. Groove casts are locally eroded into lower beds. Sandstone beds with erosional bases are rare and typically consist of medium- and coarse-grained sandstone cut into fine- and very fine-grained sandstone. Zones of carbonate-cemented, medium- and coarsegrained sandstone are present in trough-cross-stratified beds. Carbonate cement is preferentially concentrated in these broadly crossbedded zones and is probably a secondary feature controlled by original textural changes along laminae.

Sandstone layers are typically medium bedded and 1 to $20 \mathrm{~cm}$ thick. However, resistant thick-bedded ( $>50-$ $\mathrm{cm})$ units of featureless, medium and coarse sandstone are also common. Interbeds range from fine and very fine sandstone to siltstone and, locally, to shale. The transition from coarser to finer grained beds is gradational. In some exposures, 3- to 30-cm-thick beds grade from basal very coarse-grained, carbonaceous sand, upward to medium and fine sand, and, ultimately, to silt and shale.

\section{PALEONTOLOGY}

\section{Megafossils}

Megafossil analysis by W.P. Elder (written commun., 1990) indicates an early Cenomanian to early late Cenomanian age for the Gilead sandstone. One definitive Inoceramus dunveganensis McLearn was collected from the top of section 89RR20 (table 1, sample 89IM17). This 
inoceramid is characteristic of the Ninuluk Formation of Cenomanian age on the North Slope. Another inoceramid was collected stratigraphically above the Gilead sandstone on Gilead Creek and is probably a member of the Mytiloides labiatus (Schlotheim) group; it indicates an early Turonian age (table 1, sample 89AMu29-2). Numerous inoceramid specimens belonging to this group are present in the U.S. Geological Survey collections from the Seabee Formation of Cenomanian to Turonian age (W.P. Elder, written commun., 1990). These Turonian-age rocks crop out along Gilead Creek north of the Gilead sandstone. The contact relation between Turonian units at that locality and Gilead sandstone is uncertain, but similar lithology, clast types, and structures are evidence for a conformable contact or a minor unconformity.

\section{MicropaleONTOLOGY}

Palynology analysis by the Bujak Davies Group of Calgary, Alberta, Canada (written commun., 1989) and analysis of foraminifera and pollen by Micropaleo Consultants, Inc. (written commun., 1990) provide age assignments of Late Jurassic to Early Cretaceous, probable Early Cretaceous, possible Early Cretaceous to possible Albian, and Barremian to Albian for Gilead sandstone in the Sagavanirktok A-1 Quadrangle (table 1).

\section{DEPOSITIONAL ENVIRONMENT}

Sedimentologic features indicate that internally structureless sandstones are the result of amalgamation or dewatering rather than bioturbation. Local channel morphology supports the amalgamation interpretation. The absence of completely preserved Bouma sequences and local climbing ripples indicates reworking of the upper part of individual sand deposits. Amalgamated beds develop where the top of a sand bed is eroded and another sand bed is deposited without an intervening shale; the break in sedimentation may be difficult to detect.

The depositional environment of the Gilead sandstone was a middle shelf that was dominated by storm currents. Water depth in this environment may be as much as 200 $\mathrm{m}$ (Komar and others, 1972). Based on the presence of bedding-plane-parallel laminations, crossbedding, trough crossbedding, local graded bedding, shale rip-ups, and possible current reworking of the upper bed forms, the environment of deposition was dominated by single-event processes, like storm currents, and turbidity currents. Storm-related processes typically produce these structures in shelf deposits (Swift and Niedoroda, 1985). Stormsurge ebb flows transport sediment seaward across these shelves during storm events and deposit them as graded sand beds (Hayes, 1969). Subsequent storm-wave-base processes reworked, eroded, and added to these graded deposits. Locally, graded bedding with 1 - to $5 \mathrm{~cm}$-thick Bouma sequences, flute casts, possible amalgamation of sandstone beds, and shale rip-ups are evidence for deposition by turbidity currents. Molenaar and others (1984) suggested that rocks in their stratigraphic section in the Gilead syncline were produced by deep-water turbidity currents.

Distinctive climbing ripples and possibly hummocky cross-stratification are present in the Gilead sandstone, the former indicating super-saturated flow. Climbing ripples and trough cross-stratification are commonly attributed to shallow-water environments rather than classic turbidites.

\section{THERMAL-ALTERATION INDEX AND VITRINITE REFLECTANCE}

Ten Gilead sandstone samples provided TAI values ranging from 2 to 3, and eight Kingak Shale samples yielded values ranging from 3 to 4 - (table 2). Vitrinite reflectance $\left(R_{0}\right)$ for nine samples ranges from 2.32 at the base of the section to 1.03 at the top of the section; $\mathrm{R}_{\mathrm{o}}$ values for three samples of the underlying Kingak Shale ranged from 1.43 to 2.12 (Reifenstuhl, 1990). The vitrinite-reflectance gradient is approximately 1.2 $\mathrm{R}_{\mathrm{o}}$ units per 3,500 $\mathrm{ft}(1,060 \mathrm{~m})$, similar to the values for the Tunalik 1 well on the North Slope. In the Tunalik 1 well, vitrinite-reflectance and TAI values range from 0.61 and 3.2 at $3,300 \mathrm{ft}$ to 5.2 and $5+$ at $19,400 \mathrm{ft}(5,880 \mathrm{~m})$ respectively (U.S. Geological Survey, 1979). These vitrinite reflectance values yield a gradient of approximately $1 \mathrm{R}_{\mathrm{o}}$ unit per 3,500 ft $(1,060 \mathrm{~m})$. Thus, $\mathrm{R}_{\mathrm{o}}$ values and the gradient from the Gilead sandstone are consistent with other subsurface Upper and Lower Cretaceous deposits of the North Slope.

\section{REGIONAL CORRELATION}

Cenomanian megafossils at the top of the Gilead sandstone are evidence that it correlates with the Ninuluk and Chandler Formations of the Nanushuk Group. This correlation is based primarily on the early Cenomanian to early late Cenomanian age of Inoceramus dunveganensis McLearn (table 1, sample 89IM17). Stratigraphically above the Gilead sandstone, the inoceramid Mytiloides labiatus (Schlotheim) group of early Turonian age correlates with the Seabee Formation of Cenomanian to Turonian age. 
Table 1. Paleontology of Gilead sandstone (Kgs), Kingak Shale (KJk), and Upper Cretaceous (Ku) samples

\begin{tabular}{|c|c|c|c|}
\hline Sample & $\begin{array}{c}\text { Rock } \\
\text { unit }\end{array}$ & $\begin{array}{l}\text { Latitude }(\mathrm{N}) \text { and } \\
\text { longitude }(\mathrm{W})\end{array}$ & Age determination and comments \\
\hline +90IM17 & Kgs & $69^{\circ} 09^{\prime} 41^{\prime \prime} 147^{\circ} 48^{\prime} 05^{\prime \prime}$ & $\begin{array}{l}\text { Early Cenomanian to early late Cenomanian: Inoceramus } \\
\text { dunveganensis McLearn; characteristic of Ninuluk Formation } \\
\text { Top of measured section 89RR20 }\end{array}$ \\
\hline +90AMU29-2 & $\mathrm{Ku}$ & $69^{\circ} 13^{\prime} 45^{\prime \prime} 147^{\circ} 59^{\prime} 10^{\prime \prime}$ & $\begin{array}{l}\text { Early Turonian: Mytiloides labiatus (Schlotheim) group } \\
\text { Nearly identical to inoceramids from Seabee Formation } \\
\text { Gilead Creek, latitude } 69^{\circ} 13^{\prime} 50^{\prime \prime} \mathrm{N}\end{array}$ \\
\hline 89RR20-2722 & Kgs & $69^{\circ} 09^{\prime} 40^{\prime \prime} 147^{\circ} 48^{\prime} 06^{\prime \prime}$ & $\begin{array}{l}\text { \#Late Jurassic to Early Cretaceous; nonmarine to paralic } \\
\text { Top of measured section } 89 \text { RR } 20\end{array}$ \\
\hline 89MR3A & $\mathrm{Kgs}$ & $69^{\circ} 12^{\prime} 40^{\prime \prime} 147^{\circ} 55^{\prime} 20^{\prime \prime}$ & \#Jurassic to Cretaceous \\
\hline 89MR8C & Kgs & $69^{\circ} 09^{\prime} 30^{\prime \prime} 147^{\circ} 46^{\prime} 10^{\prime \prime}$ & $\begin{array}{l}\text { \#Probable Early Cretaceous; nonmarine to paralic } \\
\text { Base of Kgs measured section 89RR } 20\end{array}$ \\
\hline 89MR13C & Kgs? & $69^{\circ} 13^{\prime} 40^{\prime \prime} 147^{\circ} 58^{\prime} 55^{\prime \prime}$ & $\begin{array}{l}\text { \#Barremian to Albian; marginal marine } \\
\text { Uppermost? Kgs along Gilead Creek } \\
\text { Above fault contact with the KJk on Kishivi Creek }\end{array}$ \\
\hline NS79C & Kgs & $69^{\circ} 06^{\prime} 05^{\prime \prime} 148^{\circ} 01^{\prime} 05^{\prime \prime}$ & $\begin{array}{l}\text { \#Jurassic-Early Cretaceous; nonmarine to paralic } \\
\text { *Indeterminate; probably nonmarine } \\
\text { West side of Ivashak River; in measured section 90RR16 }\end{array}$ \\
\hline 90RR26 & Kgs & $69^{\circ} 07^{\prime} 05^{\prime \prime} 148^{\circ} 04^{\prime} 40^{\prime \prime}$ & $\begin{array}{l}\text { *Possible Early Cretaceous; probably marginal marine } \\
\text { *Possible Early Cretaceous, possible Albian; marine } \\
\text { (Foraminifera analysis); west bank Ivashak River, } 285 \text { m elevation }\end{array}$ \\
\hline 90TJR013 & $\mathrm{Kgs}$ & $69^{\circ} 07^{\prime} 55^{\prime \prime} 148^{\circ} 05^{\prime} 20^{\prime \prime}$ & $\begin{array}{l}\text { *Cretaceous; possible Early Cretaceous; marginal marine } \\
\text { West bank Ivishak River, } 280 \text { m elevation }\end{array}$ \\
\hline 89MR16C & $\mathrm{KJk}$ & $69^{\circ} 11^{\prime} 40^{\prime \prime} 147^{\circ} 36^{\prime} 55^{\prime \prime}$ & $\begin{array}{l}\text { \#Jurassic; nonmarine to paralic } \\
\text { *Probably Jurassic-early Neocomian; nonmarine }\end{array}$ \\
\hline 89MR16D & $\mathrm{KJk}$ & $69^{\circ} 11^{\prime} 40^{\prime \prime} 147^{\circ} 36^{\prime} 55^{\prime \prime}$ & $\begin{array}{l}\text { \#Jurassic to Early Cretaceous; nonmarine to paralic } \\
\text { *Probably Jurassic-early Neocomian; marginal marine }\end{array}$ \\
\hline 89MR16E & $\mathrm{KJk}$ & $69^{\circ} 11^{\prime} 40^{\prime \prime} 147^{\circ} 36^{\prime} 55^{\prime \prime}$ & $\begin{array}{l}\text { \#Bajocian (Middle Jurassic), Wallodinium elongatum Zone; } \\
\text { nonmarine to paralic } \\
\text { *Probably Jurassic-early Neocomian; nonmarine }\end{array}$ \\
\hline 89RR19A & $\mathrm{KJk}$ & $69^{\circ} 10^{\prime} 34^{\prime \prime} 147^{\circ} 42^{\prime} 47^{\prime \prime}$ & $\begin{array}{l}\text { \#Probably Jurassic; paralic to marginally marine } \\
\text { *Probably Late Jurassic } \\
\text { Base of Kgs measured section 89RR20 }\end{array}$ \\
\hline 89PE34 & $\mathrm{KJk}$ & $69^{\circ} 11^{\prime} 40^{\prime \prime} 147^{\circ} 43^{\prime} 05^{\prime \prime}$ & $\begin{array}{l}\text { \#Possible Bathonian (Middle Jurassic); paralic } \\
\text { *Probable Late Jurassic } \\
\text { Below fault contact with Kgs }\end{array}$ \\
\hline 90RR7A & $\mathrm{KJk}$ & $69^{\circ} 09^{\prime} 05^{\prime \prime} 147^{\circ} 46^{\prime} 10^{\prime \prime}$ & $\begin{array}{l}\text { \#Late Jurassic to Early Cretaceous (Oxfordian-Valanginian) } \\
\text { Foraminifera analysis; marine }\end{array}$ \\
\hline
\end{tabular}

*Analyses by Micropaleo Consultants, Inc., Encinitas, California, May and July 1990

\#Analyses by Bujak Davies Group, Calgary, Alberta, Canada, September 1989

+Analyses by W. Elder, U.S. Geological Survey, Menlo Park, California, December 1990 
Table 2. Vitrinite reflectance $\left(\mathrm{R}_{\mathrm{o}}\right)$ and thermal-alteration indices (TAI) for Gilead sandstone (Kgs) and Kingak Shale (KJk)samples

\begin{tabular}{|c|c|c|c|c|c|c|}
\hline Sample & $\begin{array}{l}\text { Rock } \\
\text { unit }\end{array}$ & $\begin{array}{l}\mathrm{R}_{\mathrm{o}} \\
\text { mean } \\
\end{array}$ & $\mathrm{R}_{\mathrm{o}}$ range & $\begin{array}{c}\text { Number of } \\
\text { readings }\end{array}$ & TAI & $\begin{array}{c}\text { Latitude (N) and } \\
\text { longitude (W) }\end{array}$ \\
\hline +89RR20-285 & Kgs & 2.18 & $1.98-2.37$ & 35 & - & $69^{\circ} 10^{\prime} 21^{\prime \prime} 147^{\circ} 42^{\prime} 55^{\prime \prime}$ \\
\hline *89RR20-285 & $\mathrm{Kgs}$ & 1.34 & $1.07-1.61$ & 11 & - & $69^{\circ} 10^{\prime} 21^{\prime \prime} 147^{\circ} 42^{\prime} 55^{\prime \prime}$ \\
\hline +89RR20-500 & $\mathrm{Kgs}$ & 2.25 & $2.06-2.43$ & 23 & - & $69^{\circ} 10^{\prime} 16^{\prime \prime} 147^{\circ} 42^{\prime} 55^{\prime \prime}$ \\
\hline *89RR20-500 & $\mathrm{Kgs}$ & 1.30 & $1.09-1.56$ & 6 & - & $69^{\circ} 10^{\prime} 16^{\prime \prime} 147^{\circ} 42^{\prime} 55^{\prime \prime}$ \\
\hline +89RR20-1826 & $\mathrm{Kgs}$ & 1.75 & $1.52-1.97$ & 55 & - & $69^{\circ} 10^{\prime} 04^{\prime \prime} 147^{\circ} 47^{\prime} 06^{\prime \prime}$ \\
\hline *89RR20-1826 & $\mathrm{Kgs}$ & 1.25 & $1.08-1.48$ & 26 & - & $69^{\circ} 10^{\prime} 04^{\prime \prime} 147^{\circ} 47^{\prime} 06^{\prime \prime}$ \\
\hline +89RR20-2722 & $\mathrm{Kgs}$ & 1.03 & $0.86-1.19$ & 13 & - & $69^{\circ} 09^{\prime} 40^{\prime \prime} 147^{\circ} 48^{\prime} 06^{\prime \prime}$ \\
\hline *89RR20-2722 & $\mathrm{Kgs}$ & 1.26 & $1.03-1.55$ & 21 & - & $69^{\circ} 09^{\prime} 40^{\prime \prime} 147^{\circ} 48^{\prime} 06^{\prime \prime}$ \\
\hline +89RR009 & $\mathrm{Kgs}$ & 2.33 & $2.17-2.51$ & 15 & - & $69^{\circ} 10^{\prime} 00^{\prime \prime} 147^{\circ} 43^{\prime} 50^{\prime \prime}$ \\
\hline +89RR70A & $\mathrm{Kgs}$ & 2.32 & $2.20-2.54$ & 35 & - & $69^{\circ} 09^{\prime} 25^{\prime \prime} 147^{\circ} 46^{\prime} 10^{\prime \prime}$ \\
\hline +89RR20-820 & Kgs & 2.12 & $1.81-2.35$ & 9 & - & $69^{\circ} 10^{\prime} 11^{\prime \prime} 147^{\circ} 42^{\prime} 59^{\prime \prime}$ \\
\hline *89MR16B & KJk & 2.12 & $1.83-2.69$ & 24 & - & $69^{\circ} 11^{\prime} 45^{\prime \prime} 147^{\circ} 36^{\prime} 39^{\prime \prime}$ \\
\hline +89RR19A & KJk & 1.43 & $1.18-1.60$ & 4 & - & $69^{\circ} 10^{\prime} 34^{\prime \prime} 147^{\circ} 42^{\prime} 47^{\prime \prime}$ \\
\hline 89MR16C & KJk & - & - & - & $3+$ & $69^{\circ} 11^{\prime} 40^{\prime \prime} 147^{\circ} 36^{\prime} 55^{\prime \prime}$ \\
\hline 89MR16D & KJk & - & - & - & $4-$ & $69^{\circ} 11^{\prime} 40^{\prime \prime} 147^{\circ} 36^{\prime} 55^{\prime \prime}$ \\
\hline 89MR16E & KJk & - & - & - & 3 & $69^{\circ} 11^{\prime} 40^{\prime \prime} 147^{\circ} 36^{\prime} 55^{\prime \prime}$ \\
\hline 89RR19A & KJk & - & - & - & $3+$ & $69^{\circ} 10^{\prime} 34^{\prime \prime} 147^{\circ} 42^{\prime} 47^{\prime \prime}$ \\
\hline 89PE34 & KJk & - & - & - & $3+$ & $69^{\circ} 11^{\prime} 40^{\prime \prime} 147^{\circ} 43^{\prime} 05^{\prime \prime}$ \\
\hline 89IM37 & KJk & - & - & - & $3-$ & $69^{\circ} 09^{\prime} 10^{\prime \prime} 147^{\circ} 47^{\prime} 00^{\prime \prime}$ \\
\hline 89IM38 & KJk & - & - & - & $4-$ & $69^{\circ} 09^{\prime} 00^{\prime \prime} 147^{\circ} 46^{\prime} 25^{\prime \prime}$ \\
\hline 89RR20-2722 & Kgs & - & - & - & 2 & $69^{\circ} 09^{\prime} 40^{\prime \prime} 147^{\circ} 48^{\prime} 06^{\prime \prime}$ \\
\hline $89 \mathrm{MR} 3 \mathrm{~A}$ & Kgs & - & - & - & $2+$ & $69^{\circ} 12^{\prime} 40^{\prime \prime} 147^{\circ} 55^{\prime} 20^{\prime \prime}$ \\
\hline 89MR8C & Kgs & - & - & - & 3 & $69^{\circ} 09^{\prime} 30^{\prime \prime} 147^{\circ} 46^{\prime} 10^{\prime \prime}$ \\
\hline 89MR13C & Kgs? & - & - & - & 2 & $69^{\circ} 13^{\prime} 40^{\prime \prime} 147^{\circ} 58^{\prime} 55^{\prime \prime}$ \\
\hline NS79C & Kgs & - & - & - & 3 & $69^{\circ} 06^{\prime} 05^{\prime \prime} 148^{\circ} 01^{\prime} 05^{\prime \prime}$ \\
\hline 89RR20-500 & Kgs & - & - & - & $3-$ & $69^{\circ} 10^{\prime} 16^{\prime \prime} 147^{\circ} 42^{\prime} 55^{\prime \prime}$ \\
\hline 89RR20-1826 & Kgs & - & - & - & 3- & $69^{\circ} 10^{\prime} 04^{\prime \prime} 147^{\circ} 47^{\prime} 06^{\prime \prime}$ \\
\hline 89RR70A & Kgs & - & - & - & $3-(?)$ & $69^{\circ} 09^{\prime} 25^{\prime \prime} 147^{\circ} 46^{\prime} 10^{\prime \prime}$ \\
\hline 89MR2C & Kgs & - & - & - & $2+$ & $69^{\circ} 12^{\prime} 45^{\prime \prime} 147^{\circ} 54^{\prime} 50^{\prime \prime}$ \\
\hline 89IM36 & Kgs & - & - & - & 3- & $69^{\circ} 12^{\prime} 40^{\prime \prime} 147^{\circ} 46^{\prime} 30^{\prime \prime}$ \\
\hline
\end{tabular}

TAI analyses by Bujak Davies Group, Calgary, Alberta, Canada, September 1989

+Measurements by U.S. Geological Survey, Denver Federal Center Laboratory, Denver, Colorado, September 1990.

*Measurements by: Dr. Alan Cook, Keiraville Consultants, Australia, December 1989

My mapping did not establish the amount of offset along the thrust fault between the Gilead sandstone and the underlying Kingak Shale, but the Gilead sandstone is faulted northward. Faulting has obscured original stratigraphic and age relations. Based on biostratigraphic evidence, I suggest that there is a significant Aptian hiatus. Whether this loss of rock record is a function of an unconformity of Aptian age or removal of part of the section by thrust faulting is unknown.

\section{ACKNOWLEDGMENTS}

I thank Charles G. Mull(DGGS) and R.Keith Crowder (University of Alaska Fairbanks) for their reviews of an early draft of this paper. Mark Robinson(DGGS) provided the computer-generated, color version of my geologic map (fig. 2). Field work was supported by DGGS and Division of Oil and Gas. 


\section{REFERENCES}

Detterman, R.L., Reiser, H.N., Brosgé, W.P. and J.T. Dutro, Jr., 1975, Post-Carboniferous stratigraphy, northern Alaska. U. S.Geological Survey Professional Paper 886, 46 p.

Gryc, George, and Mangus, M.D., 1947, Preliminary report on the stratigraphy and structure of the area of the Shaviovik and Canning Rivers, Alaska: U.S. Geological Survey Investigation of Naval Petroleum Reserve No. 4 and adjacent areas, Preliminary Report $10,7 \mathrm{p}$.

Hayes, M.O., 1969, Coastal environments, northeastern Massachusetts and New Hampshire: Society of Economic Paleontologists and Mineralologists (Eastern Section) guidebook.

Keller, A.S., Morris, R.H., and Detterman, R.L., 1961, Geology of the Shaviovik and Sagavanirktok Rivers region, Alaska: U.S. Geological Survey Professional Paper 303-D, p. D169-D222.

Komar, P.D., Neudeck, R.H., Kulm, L.D., 1972, Origin and significance of deep-water oscillatory ripple marks on the Oregon continental shelves, in Swift, K.J.P., Duane, D.B., and Pilkey, O.H., eds., Shelf sediment transport processes and pattern: Stroudsburg, Dowden, Hutchinson and Ross, p. 601-619.

Leffingwell, E. de K., 1919, The Canning River region, northern Alaska: U.S. Geological Survey Professional Paper 109, 251 p.

Molenaar, C.M., Kirk, A.R., Magoon, L.B., and Huffman, A.C., 1984, Twenty-two measured sections of Cretaceous-lower Tertiary rocks, eastern North
Slope, Alaska: U.S. Geological Survey Open-file Report 84-695, 19 p.

Payne, T.G., and others, 1951, Geology of the Arctic Slope ofAlaska: U.S. Geological Survey Oil and Gas Inventory Map OM-126, scale 1:1,000,000, 3 sheets. Pessel, G.H., Robinson, M.S., Reifenstuhl, R.R., Clough, J.G., Imm, T.A., Meigs, A.J., Mull, C.G., and Clement, R.F., in prep., Geologic map of the Sagavanirktok A-2 Quadrangle, northeastern Brooks Range, Alaska, Alaska Division of Geological and Geophysical Surveys report of investigation, scale 1:63,360, 1 sheet.

Reifenstuhl, R.R., 1989, Measured stratigraphic section of the "Gilead Creek sandstone," northeastern Alaska: Alaska Division of Geological and Geophysical Surveys Public-data File 89-26b, 15 p., scale 1:720, 1 sheet.

1990, Vitrinite reflectance for some early Tertiary through Jurassic outcrop samples, northeastern Alaska:Alaska Division of Geological and Geophysical Surveys Public-data File 90-5a, 2 p.

Swift, D.J.P., and Niedoroda, A.W., 1985, Fluid and sediment dynamics on continenal shelves, in Tillman, R.W., Swift, K.J.P., and Walker, R.G., (eds.), Shelf sands and sandstone reservoirs: Society of Economic Paleontologists and Mineralologists Short Course Notes 13, p. 47-133.

U.S. Geological Survey, 1979, Tunalik Test Well Number 1 data file, National Petroleum Reserve-Alaska, U.S. Geological Survey report, 12 p. 


\title{
KIKIKTAT MOUNTAIN KLIPPE: A LINK BETWEEN THE COPTER PEAK AND NUKA RIDGE ALLOCHTHONS, NORTHCENTRAL BROOKS RANGE, ALASKA
}

By

\author{
Diana N. Solie ${ }^{1}$ and Charles G. Mull ${ }^{1}$
}

\section{INTRODUCTION}

Kikiktat Mountain, a prominent 4,126-ft (1,250-m) peak, is located at the northern front of the central Brooks Range, about $10 \mathrm{~km}$ west of Killik River in the Killik River 1:250,000 Quadrangle (fig. 1). A small tributary of Imnaitchiak Creek separates Kikiktat Mountain from a smaller peak to the west, which is informally known as West Kikiktat Mountain; this pair of mountains constitutes the Kikiktat Mountain klippe.

The geology of Kikiktat Mountain was briefly described by Chapman and others (1964). No subsequent published geologic description of the mountain is known prior to this detailed study, which was done during June and July 1985 . The stratigraphy and generalized structure

${ }^{1}$ Alaska Division of Geological and Geophysical Surveys, 794 University Avenue, Suite 200, Fairbanks, Alaska 99709-3645. of part of the Killik River Quadrangle were discussed by Mull and others (1987); a regional geologic map of the quadrangle is in preparation by Mull and others.

We subdivide Kikiktat Mountain into three geologic units: (1) upper basalt and chert, (2) arkosic sandstone and shale, and (3) lower basalt and chert. The uppermost 500 $m$ are composed of basalt with discontinuous chert layers. This unit overlies the 30-m-thick arkosic-sandstone and shale unit, which is structurally underlain by a thinner, lower basalt and chert unit. These three units form the Kikiktat Mountain klippe, which structurally overlies sedimentary rocks of the northern Brooks Range (Mull and others, 1987).

In this paper we correlate the upper basalt and chert unit with basalt of the Copter Peak allochthon and correlate the arkosic-sandstone and shale unit with Nuka Formation in the Nuka Ridge allochthon (Mayfield and others, 1988). We tentatively correlate the lower basalt

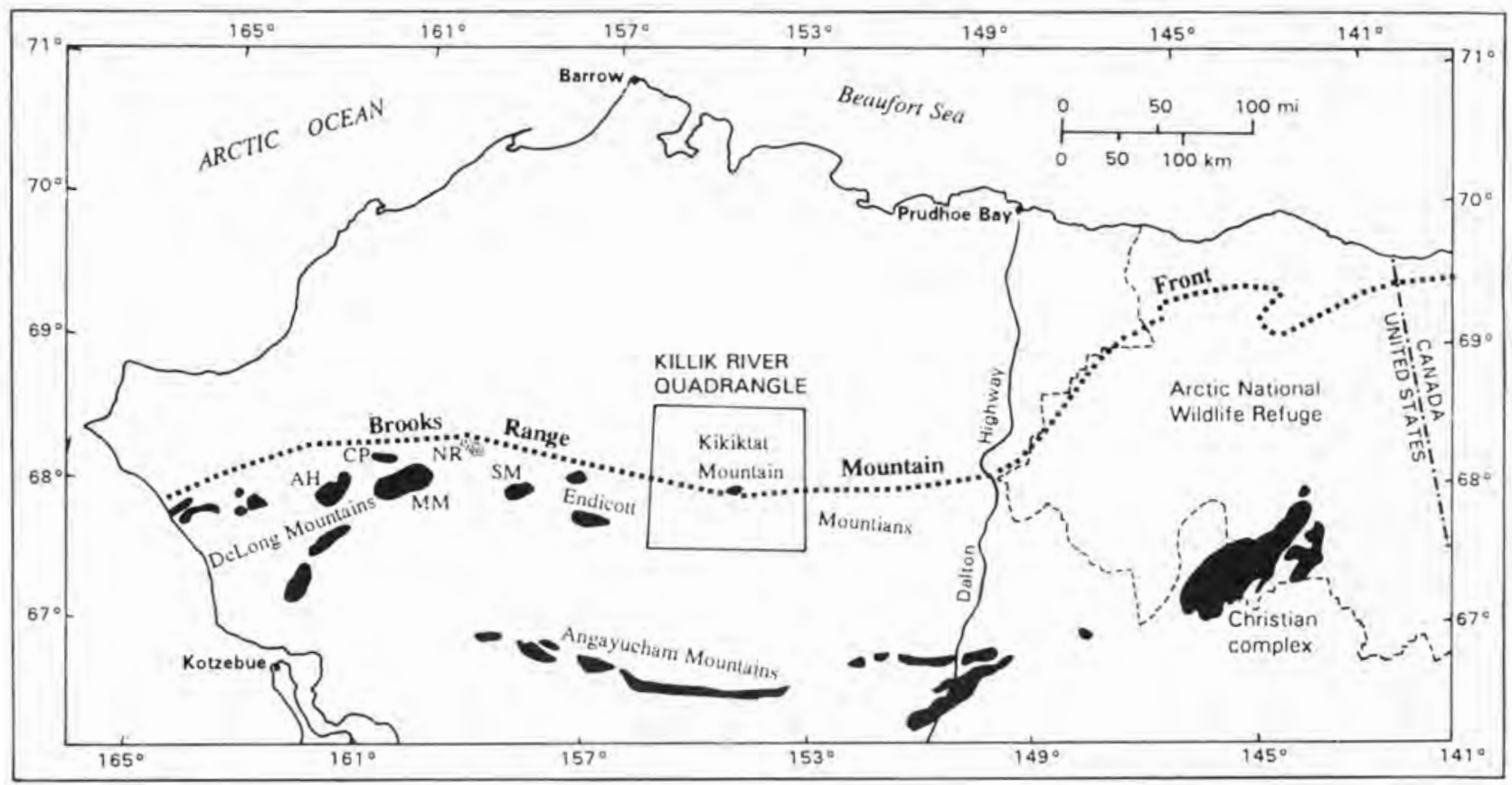

Figure 1. Map showing location of Kikiktat Mountain in the Killik River Quadrangle, Brooks Range, northern Alaska. Black areas are allochthonous basalt or gabbro and ultramafic rocks, gray area is Nuka Formation at Nuka Ridge. $\mathrm{SM}=$ Siniktanneyak Mountain, $\mathrm{MM}=$ Misheguk Mountain, $\mathrm{CP}=$ Copter Peak, $\mathrm{AH}=$ Avan Hills, $\mathrm{NR}=$ Nuka Ridge (modified from Mull, 1989, sheet 1). 
unit with mafic igneous rocks of the Ipnavik sequence in the Ipnavik allochthon (Mayfield and others, 1988). At Kikiktat Mountain, the contact between the upper basalt unit and the sedimentary unit looks depositional, leading us to suggest a stratigraphic link between the Copter Peak and Nuka Ridge allochthons, which previously were considered to be disparate thrust sheets.

\section{REGIONAL SETTING}

The central and western Brooks Range is composed of sedimentary and igneous rocks that comprise seven major allochthons that contain numerous thrust sheets (Mayfield and others, 1988). The uppermost allochthon consists mostly of ultramafic rocks and cumulate gabbro; it overlies an allochthon that consists dominantly of basalt and minor chert (Tailleur, 1970; Martin, 1970). These two upper allochthons were obducted over dominantly sedimentary rocks a minimum of $120 \mathrm{~km}$ from south to north during Late Jurassic to Early Cretaceous time (Roeder and Mull, 1978). The stacking of ultramafic and gabbroic rocks over basalt is preserved in a number of separate klippen in the western Brooks Range (Mull, 1982) and is characteristic of these rocks throughout the Brooks Range. In some localities in the western and central Brooks Range, only basalt sheets are preserved as isolated klippen; Kikiktat Mountain in the foothills of the Endicott Mountains is the easternmost well-exposed igneous klippe in the central Brooks Range (fig. 1).

The gabbro-dunite allochthon in the De Long Mountains of the western Brooks Range was named the Misheguk Mountain allochthon by Mayfield and others (1988), and erosional remnants of a basalt allochthon in the Avan Hills and at Siniktanneyak Mountain, Misheguk Mountain, Copter Peak, and other localities (fig. 1) (Zimmerman and Soustek, 1979; Nelson and others, 1979; Boak and others, 1987) were grouped into their Copter Peak allochthon. Collectively, the Misheguk Mountain and Copter Peak allochthons of oceanic or ophiolitic affinity (U.S. Geological Survey, 1973; Patton and others, 1977; Roeder and Mull, 1978) and the Christian complex in the eastern Brooks Range are considered part of the Angayucham terrane (Jones and others, 1981). The dominantly sedimentary rocks of the underlying allochthons have been assigned to the continental Arctic Alaska terrane (Jones and others, 1981).

In the western Brooks Range, the uppermost sedimentary allochthon in the Arctic Alaska terrane is the Nuka Ridge allochthon, which contains a distinctive arkosic limestone and sandstone unit termed the Nuka Formation (Tailleur and Sable, 1963; Tailleur and others, 1973; Mayfield and others, 1988). At Nuka Ridge, the type locality of the Nuka Formation in the De Long
Mountains, the formation is overlain by Pennsylvanian to Triassic chert and siliceous shale of the Etivluk Group and by Cretaceous graywacke. However, in most localities in the De Long Mountains, the Nuka Formation is overlain by basalt of the Copter Peak allochthon. In most places the boundary between the Copter igneous sequence and the Nuka Formation is not exposed, although Inyo Ellersieck (written commun., 1991) reports two exposures where the contact is a fault or detachment zone. Elsewhere, the contact is assumed to be a thrust fault by most workers because of the marked contrast between rocks of oceanic and continental affinity (Mayfield and others, 1988; Mull, 1985).

\section{STRATIGRAPHY}

\section{UPPER BASALT INTERVAL}

From a distance, the upper basalt unit on Kikiktat Mountain looks crudely stratified, the result of alternating resistant and less resistant layers (fig. 2). Although they lack well-defined tops and bottoms and are extensively fractured, resistant intervals can be interpreted as individual flows up to a few meters thick. The crude stratification defines a regional east-trending syncline with an axis through the peaks of Kikiktat Mountain. Dips on the flanks of the syncline range up to about $20^{\circ}$. Although fault planes are not exposed, local bedding convergence of about $10^{\circ}$ can be interpreted to result from thrust imbrication where north-vergent thrust faults crosscut flows and climb from one layer to another.

Well-developed pillow-basalt structures are present on Kikiktat Mountain but are not common. A generally inaccessible layer of columnar basalt can be traced for several hundred meters high on the canyon wall on the southeastern side of West Kikiktat Mountain. This columnar basalt is about $15 \mathrm{~m}$ thick and is nearly horizontal, but the columns consistently lean about $15^{\circ} \mathrm{N}$.

The upper basalt is dark green, weathers reddish brown, and is unfoliated and blocky. No coarse-grained gabbro or ultramafic rocks were observed. Milky, bluishgreen siliceous amygdules 1 to $2 \mathrm{~mm}$ in diameter are most abundant near chert horizons. Secondary minerals in fractures and veins include calcite, clear euhedral quartz crystals up to $2 \mathrm{~cm}$ long, and pale-green prehnite crystals in aggregates 1 to $2 \mathrm{~cm}$ thick.

Chert horizons up to $2 \mathrm{~m}$ thick are interlayered in the basalt. The chert is typically black to gray, but greenishgray, bluish-gray, maroon, and turquoise-blue cherts are also present. Weathering surfaces are generally white. Chert horizons can be traced for up to $50 \mathrm{~m}$, although they are commonly broken by deformation. Locally interlayered with chert are maroon, black, and green 


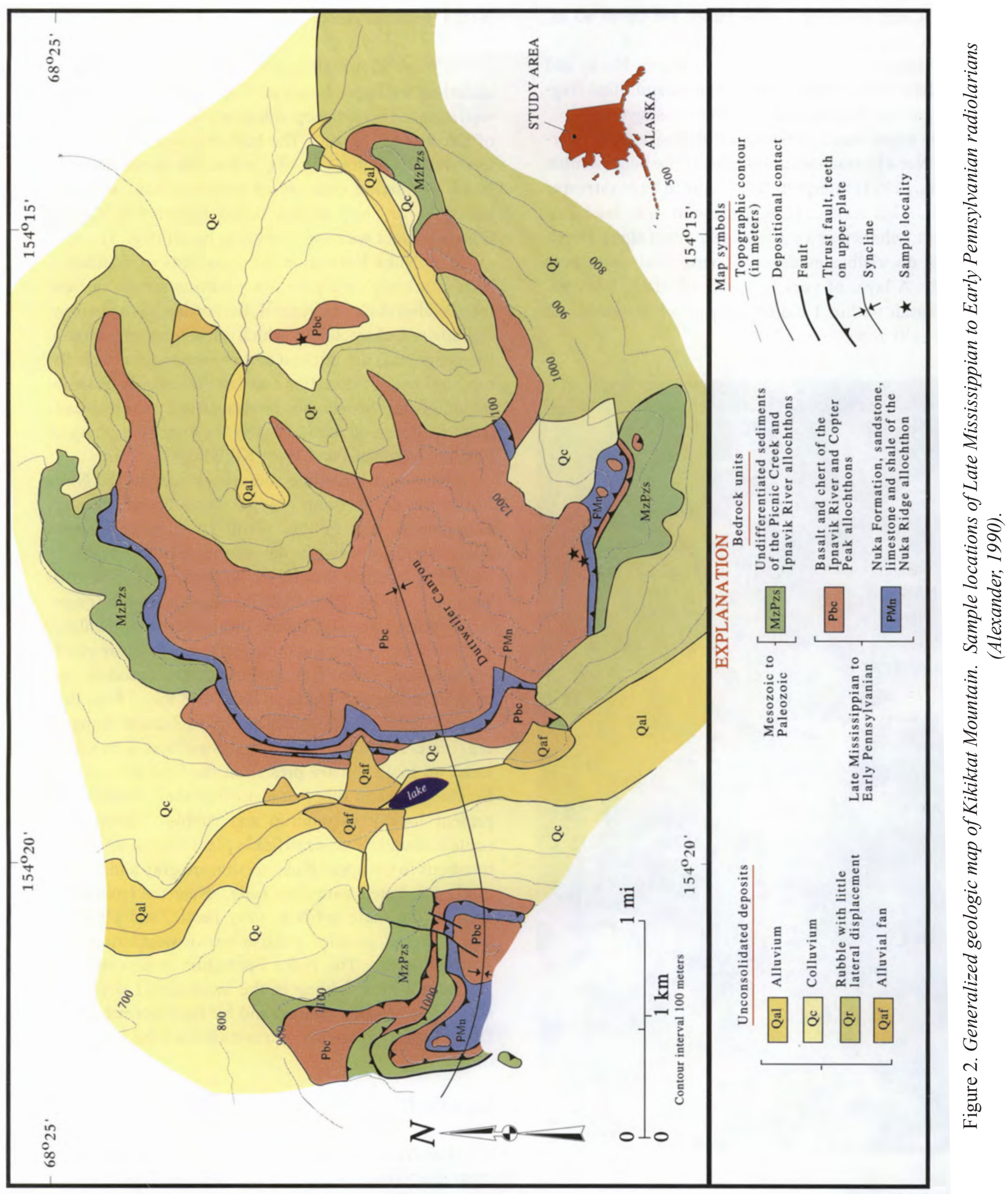


shaly layers with feldspar crystals and lithic fragments that may be remnants of tuffaceous layers.

The upper basalt looks as if it depositionally overlies the Nuka Formation, although I.L. Tailleur (written commun., 1991) interprets these units to be in intrusive contact. This contact is well exposed in at least two localities, where it is a knife-edge contact along which there is no visible evidence of structural movement (fig. 3). A layer of very fine-grained, dark, homogeneous basalt within 1 $\mathrm{cm}$ of the contact represents an altered chill zone.

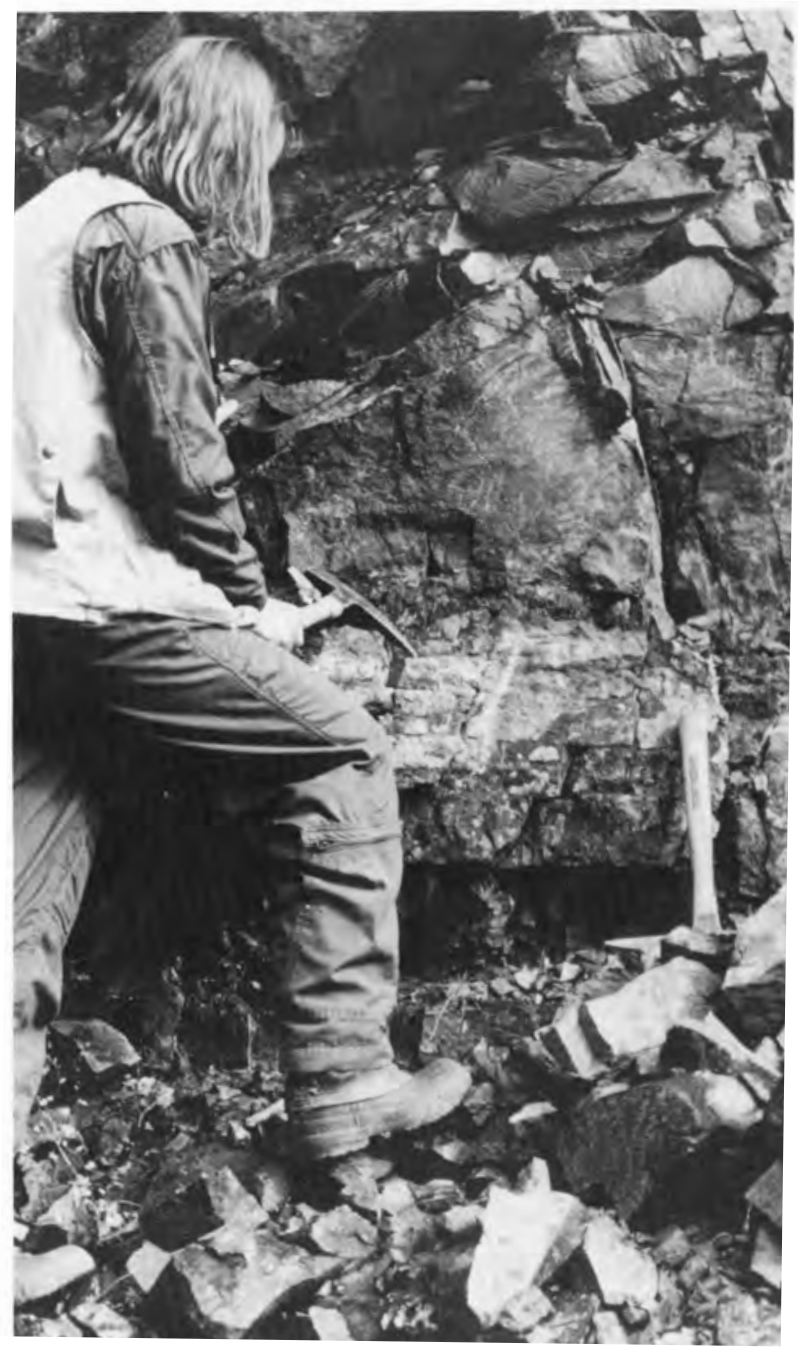

Figure 3. Photograph of unfaulted contact between top of Nuka Formation and overlying basalt in Duttweiler Canyon, southwestern side of Kikiktat Mountain. Tip of handheld hammer at contact.

\section{Nuka Formation}

A 30-m-thick section of the Nuka Formation (fig. 4) underlies the upper basalt of Kikiktat Mountain and is well exposed in two steep-sided canyons west of the crest of Kikiktat Mountain. The best exposure crops out in Duttweiler Canyon (fig. 2), where the upper meter of Nuka Formation consists of gray-to-black, silicified mudstone or chert with a baked (apparently depositional) contact with the overlying basalt (fig. 3).

The Nuka Formation there consists of distinctive beds of arkosic limestone, limy arkosic sandstone, and interbedded shale. In general, the section has a coarsening-upward character in which sandstone and arkosic limestone beds are thickest and most numerous near the top; the base of the section consists dominantly of shale. Although the Nuka Formation is relatively nonresistant, it can be observed around nearly the entire periphery of Kikiktat Mountain and West Kikiktat Mountain.

Individual limestone and arkose beds in the Nuka Formation are medium gray, weather brownish gray, range up to $1.5 \mathrm{~m}$ thick, and have many features characteristic of turbidite deposition. Beds are typically graded and contain Bouma Ta-Td sequences; some beds are amalgamated. Beds contain planar and rippled cross-laminations, starved ripples, local convolute bedding, and burrows. Quartz and unweathered feldspar grains predominate, range from subangular to rounded, and vary from fine grained to as large as $8 \mathrm{~mm}$. Rounded-to-subangular black-shale clasts up to $3 \mathrm{~cm}$ in diameter are common in some beds; large megaflutes with amplitudes up to $15 \mathrm{~cm}$ are present at the base of one bed. Brachiopods and other unidentified shell material are present locally in outcrop and rubble. Some beds contain abundant unidentifiable plant fragments. Shale interbeds in the upper Nuka section are gray and contain thinly laminated sandstone beds. Near the base of the section, the shale is black, very fissile, and phyllitic, with scattered, rounded, reddish-brown-weathering limestone nodules. The Nuka Formation is deformed by small-scale kink folding in the interlayered shales, by slip along bedding planes, and by later normal faults. Deformation apparently increases toward the lower part of the unit.

\section{LOWER BASALt INTERVAL}

The Nuka Formation is underlain by a basalt-andchert interval about 30 to $50 \mathrm{~m}$ thick, which is similar to the upper basalt of Kikiktat Mountain but consists of only a few basalt layers and has well-developed slickensides between many layers. At one locality on West Kikiktat mountain, dark-green conglomerate and sandstone with clasts of black-and-blue chert are apparently interlayered 


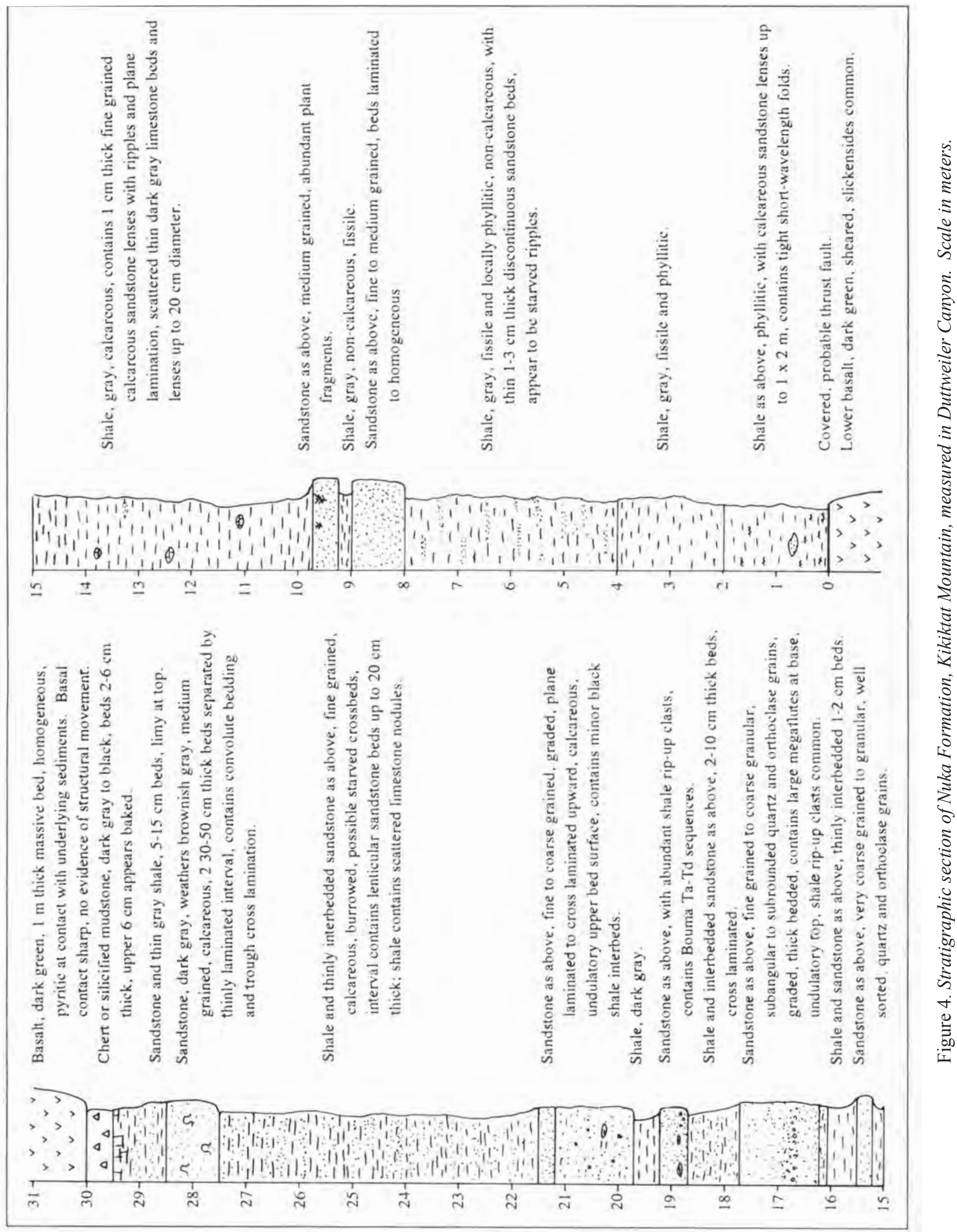


with the basalt. These rocks are similar to nearby Cretaceous conglomerate and are interpreted to be a fault sliver in the basalt.

The top of the lower basalt unit is marked by intense shearing and brecciation; this deformation, combined with increased deformation toward the base of the Nuka Formation, indicates that the Nuka Formation-lower basalt contact is a thrust fault. The base of the lower basalt unit is not exposed but apparently is a thrust fault because it overlies the Cretaceous conglomerate and other rocks of the sedimentary allochthons. This lowermost fault forms the base of the Kikiktat klippe.

\section{PETROGRAPHY AND ANALYTICAL DATA}

\section{BASALT}

Modal composition of the basalt is uniform throughout Kikiktat Mountain with no appreciable difference between upper and lower basalt intervals. The basalts consist primarily of plagioclase, clinopyroxene, opaque oxides, and secondary minerals. Green micaceous alteration minerals (celadonite?) and titanite, some in euhedral forms, may be pseudomorphs of primary orthopyroxene or olivine. Other alteration minerals include iron oxide, chlorite, biotite, calcite, sericite, epidote, and opaque minerals. The degree of alteration varies; freshest samples have $<1$ percent secondary minerals, and the least fresh samples are nearly all altered. No glass is recognizable in thin section. Point counts of six thin sections ( 400 points each) yield average modal percentages of about 53 percent plagioclase (predominantly labradorite), 36 percent augite, 6 percent opaque minerals (including magnetite, ilmenite(?), and pyrrhotite), and 5 percent pseudomorphs. The basalt is aphanitic to fine grained; some samples have phenocrysts of clinopyroxene or plagioclase, or both, up to about $5 \mathrm{~mm}$. Foliation is absent; textures are generally intersertal.

Major-oxide analyses of nine representative basalts from Kikiktat Mountain are shown in table 1 with accompanying CIPW norm calculations for each sample. Four samples are quartz normative; none are nepheline normative. According to the Yoder and Tilley (1962) classification, the samples are tholeiites and olivine tholeiites. A variation diagram plotting $\mathrm{Na}_{2} \mathrm{O}+\mathrm{K}_{2} \mathrm{O}$ versus $\mathrm{SiO}_{2}$ shows a spread in alkalies over a small range in $\mathrm{SiO}_{2}$ (fig. 5). Applying the Macdonald and Katsura (1964) classification, the samples span the tholeiite to alkali basalt fields. On an AFM diagram (fig. 6), the samples have a high proportion of iron typical of the tholeiitic suite.
However, the possibility of alkali mobility in these basalts cannot be discounted because of minor alteration of all basalts examined.

\section{Nuka Formation}

Thin sections of sandstone from the Nuka Formation contain grains of quartz, alkali feldspar, plagioclase, opaque oxides, up to 45 percent carbonate, and trace amounts of zircon \pm biotite \pm white mica \pm chlorite \pm titanite and hematite. Alkali-feldspar grains include subrounded microcline and perthite up to $3 \mathrm{~mm}$ diameter. Quartz is highly strained, and there is extensive subgrain development and recrystallization of some grains. Plagioclase is present in variable amounts and tends to be smaller than alkali-feldspar grains. Metamorphic foliation is not evident. Most sandstone layers contain invertebrate fossil fragments, including foraminifera, bryozoa, brachiopods, trilobites, ostracods, and pelmatozoan debris. Micritic filling in bryozoa fragments indicates that at least some of these fossils have been reworked.

\section{AGE}

Limited faunal data constrain the age of the rock units on Kikiktat Mountain to the late Paleozoic Era. Radiolarians have been recovered from cherts interbedded with the upper basalt at four locations on Kikiktat Mountain. T.E.Moore (written commun., 1987, in Alexander, 1990) reported a Late Mississippian to Early Pennsylvanian age for a sample collected near the top of Kikiktat Mountain. K.M. Reed and B.L. Murchey (written commun., 1986 and 1987, in Alexander, 1990) reported Late Mississippian to Early Pennsylvanian radiolarians from one of three chert samples in the upper basalt unit (fig. 2).

Conodonts from a probable float sample of the Nuka Formation collected by I.L. Tailleur in Duttweiler Canyon about $15 \mathrm{~m}$ below the basalt are dated as Late Meramecian to Early Chesterian (middle Late Mississippian) by Anita Harris (U.S Geological Survey). Megafossils collected from the Nuka Formation at Kikiktat Mountain and another nearby locality yielded conflicting age interpretations. Corals from an isolated outcrop of typical Nuka arkosic limestone on Imnaitchiak Creek $12 \mathrm{~km}$ northwest of Kikiktat Mountain are dated by W.J. Sando (written commun., 1984) as Mississippian-Pennsylvanian and no younger than Desmoinesian (Middle Pennsylvanian). Brachiopods of uncertain identification from two localities in the Nuka Formation at Kikiktat Mountain and corals from another locality on Imnaitchiak Creek to the north are considered to be Permian (J.T.Dutro, Jr., written commun., 1984). However, paleontological data 
Kikiktat Mountain Klippe: A Link Between the Copter Peak and Nuka Ridge Allochthons

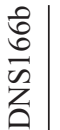

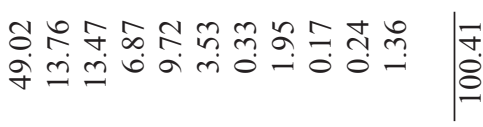

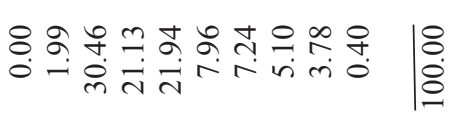

8

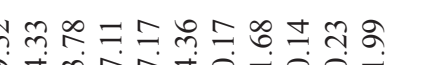

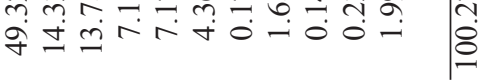

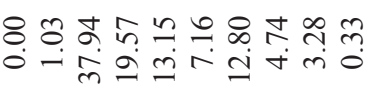

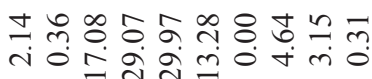

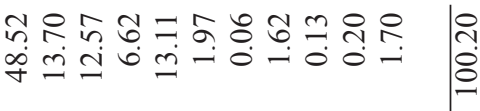

त०

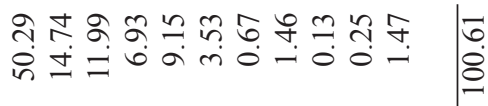

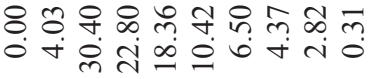

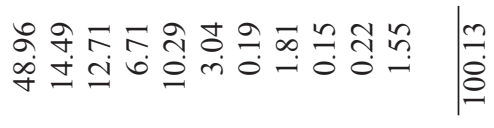

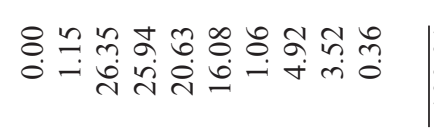

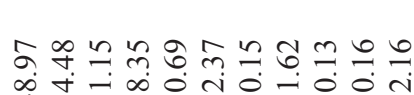

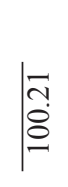

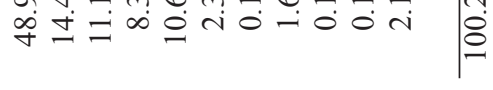

플

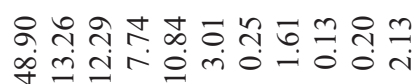

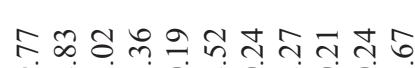

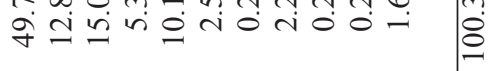

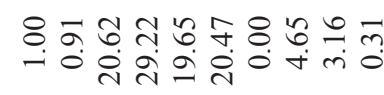

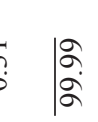

ป⿱艹

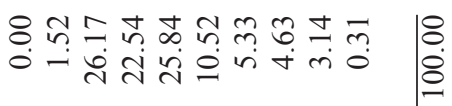

ำฺ 年 的 $-\bar{n}$ त่ 


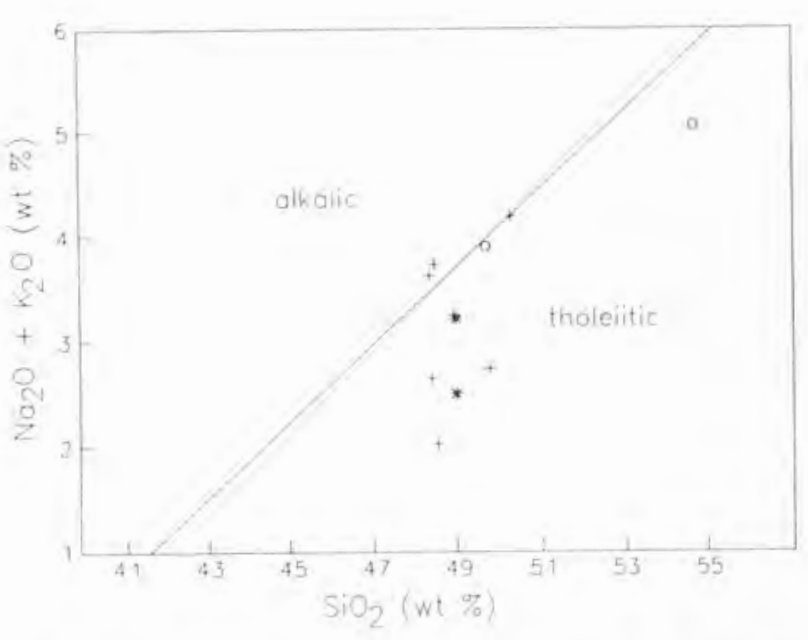

Figure 5. Plot of alkalies against silica in selected central Brooks Range basalts. + is Kikiktat Mountain upper basalt (this study), * is Kikiktat Mountain lower basalt (this study), ${ }^{\circ}$ is Paleozoic Angayucham basalt (Pallister and others, 1989). Line distinguishing tholeiitic from subalkaline fields is from Macdonald and Kutsura (1964).

on the age of the type Nuka Formation are also contradictory in the western Brooks Range, where arkosic beds originally considered to be Permian (Tailleur and Sable, 1963; Tailleur and others, 1973) are now considered to be Late Mississippian and Early Pennsylvanian(?) based on dating of conodonts and foraminifera (Mayfield and others, 1984). In summary, the preponderance of evidence favors a Late Mississippian to Early Pennsylvanian age for both the Nuka Formation and the overlying basalt at Kikiktat Mountain.

Detrital microcline grains from the Nuka Formation in its type area are dated as 1.2 to $1.8 \mathrm{Ga}$ by K-Ar methods (Tailleur, 1985). Detrital zircons from the type area yielded evidence for $2.07 \mathrm{Ga}$ rocks in the source area of the Nuka Formation, based on U-Pb dating methods (Hemming and others, 1989). The source of the granitic rock from which these grains were derived is not known.

\section{TECTONIC SETTING}

The unique association of basalt overlying arkosic carbonates indicates an unusual tectonic setting for the deposits of Kikiktat Mountain. Coarse-grained quartz and unweathered alkali feldspar in turbidite deposits of

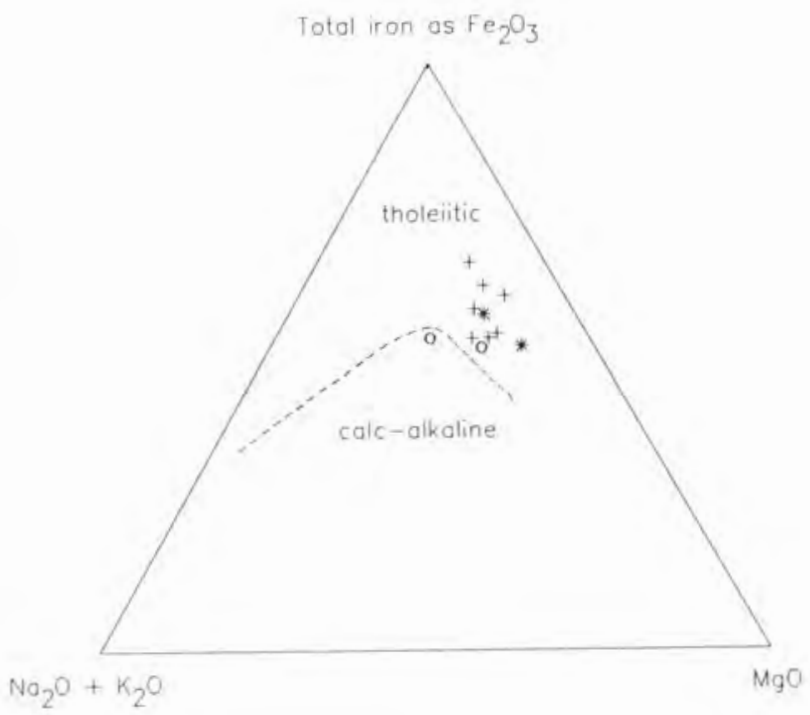

Figure 6. AFM diagram plotting alkalies $\left(\mathrm{Na}_{2} \mathrm{O}+\mathrm{K}_{2} \mathrm{O}\right)$, iron (total iron as $\mathrm{Fe}_{2} \mathrm{O}_{3}$ ) and magnesium $(\mathrm{MgO})$ in selected central Brooks Range basalts. + is Kikiktat Mountain upper basalt (this study), * is Kikiktat Mountain lower basalt (this study), ${ }^{\circ}$ is Paleozoic Angayucham basalt (Pallister and others, 1989). Dashed line distinguishing tholeiitic from calcalkaline trends is from Irvine and Baragar (1971).

the Nuka Formation at Kikiktat Mountain are evidence of rapid erosion of a granitic source and minimal reworking before submarine deposition. Detrital fossils and carbonate indicate proximity to a carbonate platform. Pillow basalt interlayered with chert indicates predominantly submarine deposition, although the presence of columnar basalt implies of at least some subaerial flows, constraining deposition to a shallow, probably nearshore environment.

Major-oxide data for basalt from Kikiktat Mountain do not discriminate between continental margin and mid-oceanic settings. Pyroxene compositions (table 2) plotted on the discriminant diagram of Nisbet and Pearce (1977) fall in both the ocean-floor-basalt field and the field representing pyroxenes from all tectonic settings (fig. 7), providing an ambiguous tectonic interpretation based on pyroxene composition. However, the overall tholeiitic character of the basalts and the presence of both quartznormative and olivine + hypersthene-normative basalts is more typical of tensional rather than compressional tectonic settings (Barker, 1983). The combination of these features is indicative of nearshore turbidite deposition at a passive or transform continental margin followed by deposition of basalt flows and chert in a rift environment. 
Table 2. Electron-microprobe analyses of clinopyroxene and plagioclase from Kikiktat Mountain upper basalt samples $^{\mathrm{a}}$

\begin{tabular}{|c|c|c|c|c|c|c|}
\hline Sample & $\begin{array}{l}\text { 85DNS108 } \\
\text { cpx }\end{array}$ & $\begin{array}{l}\text { 85DNS108 } \\
\text { cpx }\end{array}$ & $\begin{array}{l}\text { 85DNS108 } \\
\text { cpx }\end{array}$ & $\begin{array}{l}\text { 85DNS151f } \\
\quad \mathrm{cpx}\end{array}$ & $\begin{array}{l}\text { 85DNS151f } \\
\text { cpx }\end{array}$ & $\begin{array}{l}\text { 85DNS108 } \\
\text { plag }\end{array}$ \\
\hline $\mathrm{SiO} 2$ & 51.23 & 53.22 & 52.15 & 51.67 & 52.12 & 50.71 \\
\hline $\mathrm{TiO} 2$ & 0.98 & 0.49 & 0.71 & 0.64 & 0.51 & 0.07 \\
\hline $\mathrm{A} 12 \mathrm{O} 3$ & 1.75 & 2.04 & 3.35 & 3.47 & 2.52 & 31.67 \\
\hline $\mathrm{FeO}^{*}$ & 18.03 & 7.61 & 8.00 & 7.72 & 7.25 & 0.74 \\
\hline $\mathrm{MnO}$ & 0.48 & 0.20 & 0.24 & 0.22 & 0.21 & 0.00 \\
\hline $\mathrm{MgO}$ & 14.72 & 18.90 & 17.23 & 16.54 & 16.67 & 0.23 \\
\hline $\mathrm{CaO}$ & 13.75 & 18.00 & 19.13 & 19.34 & 20.04 & 14.82 \\
\hline $\mathrm{Na} 2 \mathrm{O}$ & 0.23 & 0.15 & 0.22 & 0.24 & 0.22 & 3.40 \\
\hline Total & $\overline{101.17}$ & $\overline{100.61}$ & $\overline{101.03}$ & 99.84 & 99.54 & 101.64 \\
\hline \multicolumn{7}{|c|}{ FORMULAE } \\
\hline $\mathrm{Si}$ & 1.927 & 1.936 & 1.900 & 1.906 & 1.926 & 2.283 \\
\hline $\mathrm{Al}$ & 0.073 & 0.064 & 0.100 & 0.094 & 0.074 & 1.680 \\
\hline SUM & 2.000 & 2.000 & 2.000 & 2.000 & 2.000 & 3.963 \\
\hline $\mathrm{Al}$ & 0.005 & 0.023 & 0.044 & 0.056 & 0.036 & - \\
\hline $\mathrm{Ti}$ & 0.028 & 0.013 & 0.019 & 0.018 & 0.014 & - \\
\hline $\mathrm{Fe}$ & 0.567 & 0.231 & 0.244 & 0.238 & 0.224 & 0.028 \\
\hline $\mathrm{Mn}$ & 0.015 & 0.006 & 0.007 & 0.007 & 0.007 & 0.000 \\
\hline $\mathrm{Mg}$ & 0.825 & 1.025 & 0.936 & 0.909 & 0.918 & 0.015 \\
\hline SUM & 1.440 & 1.298 & 1.250 & 1.228 & 1.199 & - \\
\hline $\mathrm{Ca}$ & 0.554 & 0.701 & 0.747 & 0.764 & 0.794 & 0.715 \\
\hline $\mathrm{Na}$ & 0.017 & 0.011 & 0.016 & 0.017 & 0.001 & 0.297 \\
\hline SUM & 0.571 & 0.712 & 0.763 & 0.781 & 0.795 & 1.055 \\
\hline $\mathrm{O}$ & 6.000 & 6.000 & 6.000 & 6.000 & 6.000 & 8.000 \\
\hline
\end{tabular}

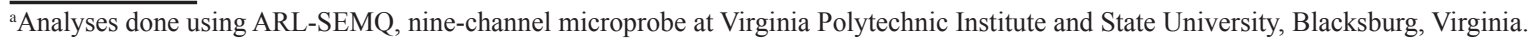

\section{DISCUSSION}

Comparison of Kikiktat Mountain rocks with similar lithologies in the western and southern Brooks Range is the basis for correlations that may constrain the tectonic setting of Kikiktat Mountain. In the De Long Mountains, the Nuka Ridge allochthon structurally overlies the Ipnavik River allochthon, which is characterized by dark-gray basinal limestone and black chert of Carboniferous age associated with numerous fine-grained mafic sills and dikes (Mayfield and others, 1988). Mafic sills and dikes have been interpreted as evidence of a late Pennsylvanian or younger rifting event (Mayfield and others, 1988). The lower basalt unit at Kikiktat Mountain occupies the structural position of the Ipnavik River allochthon, and we suggest that it could either be part of the Ipnavik River allochthon or structurally emplaced slivers of the Copter Peak allochthon. Alexander (1990) reported discontinuous exposures of chert, mafic intrusive, and Cretaceous rocks in the lowland at the base of Kikiktat Mountain, which he assigns to the Ipnavik River alloch- thon. Structurally below the Ipnavik River allochthon at Kikiktat Mountain, rocks of the Picnic Creek allochthon are widespread (Mull and others, 1987). This stacking order of structural sequences is identical to that reported by Mayfield and others (1988) in the eastern De Long Mountains.

The distinctive Nuka Formation sandstone at Kikiktat Mountain is very similar to the Nuka Formation in the western Brooks Range, although the type Nuka Formation is not described as a turbidite. In addition, the shale in the lower part of the Nuka Formation at Kikiktat Mountain closely resembles the Kayak Shale in the type area of the Nuka Formation (Mayfield and others, 1988). Examination of thin sections of sandstone from Nuka Ridge reveals that clastic grains of the type Nuka Formation consist of quartz, alkali feldspar, calcite, and opaque minerals \pm biotite \pm hornblende \pm zircon and \pm fossils. Source rocks for much of the clastic material in both the type Nuka Formation and the Nuka Formation at Kikiktat Mountain are probably granites. However, the Kikiktat source was apparently a subsolvus granite 


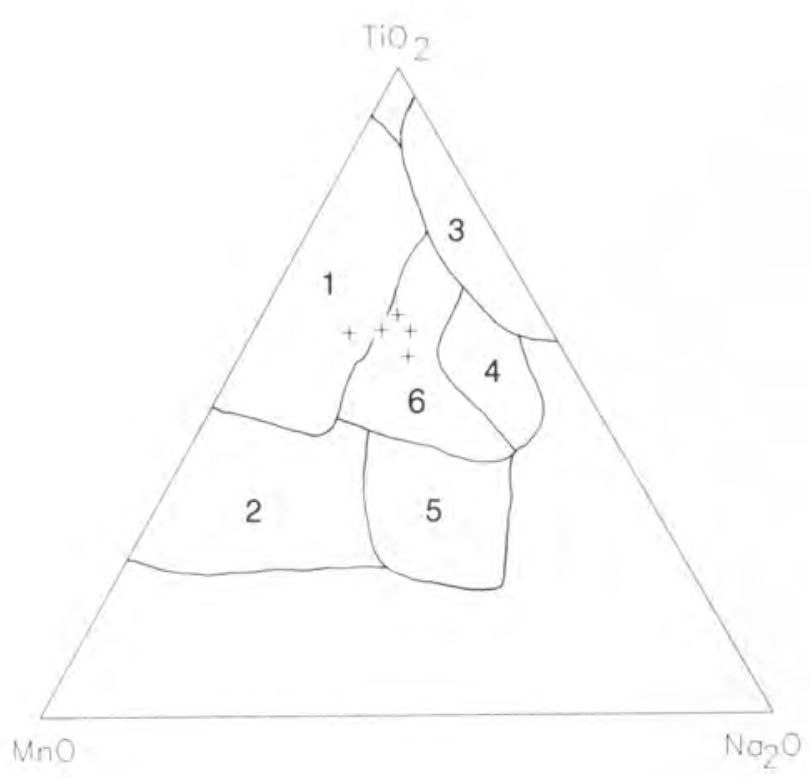

Figure 7. Plot of clinopyroxene in Kikiktat Mountain upper basalt in terms of $\mathrm{TiO}_{2}, \mathrm{MnO}$, and $\mathrm{Na}_{2} \mathrm{O}$, showing fields of tectonic settings (Nisbet and Pearce, 1977). Field labels: $1=$ ocean-floor basalt $(O F B), 2$ = volcanic-arc basalt (VAB), 3 = withinplate alkalic basalt (WPA), $4=$ within-plate tholeiitic basalt $(W P T)+W P A+V A B, 5=V A B+W P A$, $6=O F B+V A B+W P A+W P T$.

containing biotite \pm muscovite, whereas the type Nuka Formation was apparently derived from a hypersolvus granite (no calcic plagioclase) containing biotite \pm amphibole. Thus, despite close similarities that indicate similar tectonic settings and depositional environments for the Nuka Formation at Kikiktat Mountain and the type Nuka Formation, their sources are not identical.

The Copter igneous sequence at Copter Peak in the western Brooks Range includes pillow basalt and minor andesite with some intercalated shale and gray, green, and maroon cherts containing Triassic radiolarians (Mayfield and others, 1988). Pillow basalt and diabase at Siniktanneyak Mountain in the eastern De Long Mountains are tentatively correlated with the Copter igneous sequence (Mayfield and others, 1988) and are associated with fossils ranging in age from Devonian to Triassic (Nelson and others, 1979). Mafic rocks of the Angayucham terrane are also considered part of the Copter igneous sequence and are Late Devonian to Early Jurassic in age, based on associated radiolarians and conodonts (Barker and others, 1988; Pallister and others, 1989; Dillon, 1989). Thus, the Copter igneous sequence includes rocks ranging in age from Devonian to Jurassic and could represent a changing tectonic setting through time.

Two whole-rock major-oxide analyses of Angayucham basalt of Paleozoic age from the central Brooks
Range are published (Pallister and others, 1989); one is similar to the basalt of Kikiktat Mountain (figs. 5 and 6). Pallister and others (1989) concluded that basalt of Mesozoic age in the Angayucham Mountains is an accreted oceanic plateau. However, they did not specifically address the tectonic origin of the Paleozoic basalt. Therefore, a correlation of the Kikiktat Mountain klippe with the Paleozoic basalt of the Angayucham Mountains does not conclusively resolve the tectonic setting of the klippe.

Moore (1987) stated that the Kikiktat Mountain basalt displays flat rare-earth-element patterns and is most similar to dikes of the Ipnavik sequence, but it is generally also geochemically similar to basalt of Copter Peak and Siniktanneyak Mountain. He concluded that basalt from Copter Peak allochthon at Siniktanneyak Mountain and Copter Peak geochemically correlates with Angayucham-terrane basalt of inferred oceanic-plateau origin but that Kikiktat Mountain basalt and Ipnaviksequence dikes and sills could indicate a rift origin.

\section{CONCLUSIONS}

Field and petrographic evidence at Kikiktat Mountain clearly reveal the undisturbed contact of the upper basalt at Kikiktat Mountain over the arkosic sandstone and shale of the Nuka Formation (fig. 3). We conclude that the upper basalt at Kikiktat Mountain correlates best with the Copter Peak allochthon, based on lithology, age, and structural position. The Kikiktat Mountain basalt was probably extruded in an extensional tectonic environment during late Paleozoic time and may be the extrusive equivalent of mafic dikes and sills of the Ipnavik sequence. The basalt flows were extruded over marine sediments of the Nuka Formation, which were probably deposited near a carbonate platform at a passive or transform margin and which had a Pre-cambrian continental source of detritus. Thus, the Copter Peak and Nuka Ridge allochthons at Kikiktat Mountain represent a single structural package of late Paleozoic rocks. However, because of the wide range in ages of basalts that have been correlated with the Copter Peak igneous sequence, it is likely that the Copter Peak allochthon elsewhere includes basalt of different tectonic settings and is a distinct structural entity.

Similar relations exist in the southern De Long Mountains where Nuka Formation is overlain by basalt in a number of areas. Although this contact is a fault contact at the few places where it is actually exposed, in view of the pervasiveness of thrusting in the De Long Mountains, we suggest that the fault is a thrust or detachment along an original depositional contact between basalt and Nuka Formation This relation contrasts with the type Nuka Formation at Nuka Ridge in the northern 
De Long Mountains, where Nuka Formation is overlain by Pennsylvanian to Triassic siliceous shale and chert of the Etivluk Group and by Cretaceous graywacke. These contrasting relations indicate that after deposition of the Nuka Formation, normal marine sedimentary processes occurred contemporaneously with extrusion of basalt in other areas. Such rapid lateral facies changes are compatible with the interpretation of basalt extruded in a rift setting.

\section{ACKNOWLEDGMENTS}

We thank R.J. Alexander for helpful discussions. J.P. Siok was of great help in measuring the sedimentary section and also supplied thin sections from the type Nuka Formation. T.N. Solberg helped with microprobe analyses at Virginia Polytechnic Institute and State University. Reviews by G.H. Pessel (DGGS), T.E. Moore (USGS), R.R. Reifenstuhl (DGGS), I.L. Tailleur (USGS), and Inyo Ellersieck (USGS) are appreciated. Mark Robinson (DGGS) provided the computer-generated, colored version of our geologic map (fig. 2).

\section{REFERENCES}

Alexander, R.J, 1990, Structure and lithostratigraphy of the Kikiktat Mountain area, central Killik River Quadrangle, northcentral Brooks Range, Alaska: Fairbanks, University of Alaska unpublished M.S. thesis, $237 \mathrm{p}$.

Barker, D.S., 1983, Igneous rocks: Englewood Cliffs, N.J., Prentice-Hall, Inc., 417 p.

Barker, Fred, Jones, D.L, Budahn, J.R., and Coney, P.J., 1988, Ocean plateau-seamount origin of basaltic rocks, Angayucham terrane, central Alaska: Journal of Geology, v. 96, no. 3, p. 368-374.

Boak, J.M., Turner, D.L., Henry, D.J., Moore, T.E., and Wallace, W.K., 1987, Petrology and K-Ar ages of the Misheguk igneous sequence-an allochthonous mafic and ultramafic complex-and its metamorphic aureole, western Brooks Range, Alaska, in Tailleur, Irv, and Weimer, Paul, eds., Alaska North Slope geology: Society of Economic Paleontologists and Mineralogists and Alaska Geological Society Book 50, v. 2, p. 737-745.

Chapman, R.M., Detterman, R.L., and Mangus, M.D., 1964, Geology of the Killik - Etivluk Rivers region, Alaska: U.S. Geological Survey Professional Paper 303-F, p. 325-407.

Dillon, J.T., 1989, Structure and stratigraphy of the southern Brooks Range and northern Koyukuk Basin near Dalton Highway, in Mull, C.G., and Adams, K.E., eds., Dalton Highway, Yukon River to Prudhoe Bay, Alaska, bedrock geology of the eastern Koyukuk
Basin, central Brooks Range, and eastcentral Arctic Slope: Alaska Division of Geological and Geophysical Surveys Guidebook 7, v. 2, p. 158-187.

Hemming, Sidney, Sharp, W.D., Moore, T.E., and Mezger, Klaus, 1989, $\mathrm{Pb} / \mathrm{U}$ dating of detrital zircons from the Carboniferous Nuka Formation, Brooks Range, Alaska: Evidence for a 2.07 Ga provenance (abs.): Geological Society of America Abstracts with Programs, v. 21, no. 6, p. A190.

Irvine, T.N., and Baragar, W.R.A., 1971, A guide to the chemical classification of the common volcanic rocks: Canadian Journal of Earth Science, v. 8, no. 5, p. 523-548.

Jones, D.L., Silberling, N.J., Berg, H.C., and Plafker, George, 1981, Tectonostratigraphic terrane map of Alaska: U.S. Geological Survey Open-file Report 81-792, 20 p., scale 1:2,500,000, 2 sheets.

Macdonald, G.A., and Katsura, T., 1964, Chemical composition of Hawaiian lavas: Journal of Petrology, $v$. 5, no. 1, p. 82-133.

Martin, A.J., 1970, Structure and tectonic history of the western Brooks Range, De Long Mountains and Lisburne Hills, northern Alaska: Geological Society of America Bulletin, v. 81, no. 12, p. 3605-3622.

Mayfield, C.F., Curtis, S.M., Ellersieck, Inyo, and Tailleur, I.L., 1984, Reconnaissance geologic map of southeastern Misheguk Mountain Quadrangle, Alaska: U.S. Geological Survey Miscellaneous Investigations Map I-1503, scale 1:63,360, 2 sheets.

Mayfield, C.F., Tailleur, I.L., and Ellersieck, Inyo, 1988, Stratigraphy, structure, and palinspastic synthesis of the western Brooks Range, northwestern Alaska, in Gryc, George, ed., Geology and exploration of the National Petroleum Reserve in Alaska, 1974 to 1982: U.S. Geological Survey Professional Paper 1399, p. 143-186.

Moore, T.E., 1987, Geochemical and tectonic affinity of basalts from the Copter Peak and Ipnavik River allochthons, Brooks Range, Alaska (abs.): Geological Society of America Abstracts with Programs, v. 19, no. 6, p. 434.

Mull, C.G., 1982, Tectonic evolution and structural style of the Brooks Range, Alaska:An illustrated summary, in Powers, R.B., ed., Geological studies on the Cordilleran thrust belt: Rocky Mountain Association of Geologists, v. 1, p. 1-46.

1985, Cretaceous tectonics, depositional cycles, and the Nanushuk Group, Brooks Range and Arctic Slope, Alaska, in Huffman, A.C., Jr., ed., Geology of the Nanushuk Group and related rocks: U.S. Geological Survey Bulletin 1614, p. 7-36. 
Mull, C.G., 1989, Generalized geologic map of the Brooks Range and Arctic Slope, northern Alaska, in Mull, C.G., and Adams, K.E., eds., Dalton Highway, Yukon River to Prudhoe Bay, Alaska: Alaska Division of Geological and Geophysical Surveys Guidebook 7, v. 1, scale 1:2,851,200, 1 sheet.

Mull, C.G., Crowder, R.K., Adams, K.E., Siok, J.P., Bodnar, D.A., Harris, E.E., Alexander, R.A., and Solie, D.N., 1987, Stratigraphy and structural setting of the Picnic Creek allochthon, Killik River Quadrangle, central Brooks Range, Alaska: A summary, in Tailleur, Irv, and Weimer, Paul, eds., Alaska North Slope geology: Society of Economic Paleontologists and Mineralogists and Alaska Geological Society Book 50, v. 2, p. 649-662.

Nelson, S.W., Nokleberg, W.J., Miller-Hoare, Martha, and Mullen, M.W., 1979, Siniktanneyak Mountain ophiolite, in Johnson, K.M., and Williams, J.R., eds., The United States Geological Survey in Alaska: Accomplishments during 1978: U.S. Geological Survey Circular 804-B, p. B14-B16.

Nisbet, E.G., and Pearce, J.A., 1977, Clinopyroxene composition in mafic lavas from different tectonic settings: Contributions to Mineralogy and Petrology, v. 63 , no. 2 , p. 149-160.

Pallister, J.S., Budahn, J.R., and Murchey, B.L., 1989, Pillow basalts of the Angayucham terrane: oceanic plateau and island crust accreted to the Brooks Range: Journal of Geophysical Research, v. 94, no. B11, p. 15901-15923.

Patton, W.W., Jr., Tailleur, I.L., Brosgé, W.P., and Lanphere, M.A., 1977, Preliminary report on the ophiolites of northern and western Alaska, in Colemen, R.G., and Irwin, W.P., eds., North American ophiolites: Oregon Department of Geology and Mineral Industries Bulletin 95, 183 p.
Roeder, Dietrich, and Mull, C.G., 1978, Tectonics of Brooks Range ophiolites, Alaska: American Association of Petroleum Geologists Bulletin, v. 62, no. 9, p. 1696-1713.

Tailleur, I.L., 1970, Structure and stratigraphy of western arctic Alaska (abs.): American Association of Petroleum Geologists Bulletin, v. 54, no. 12, p. 2508. 1985, Letter to the editor, in Hankins, H., ed., Reverberations: Alaska Geological Society Newsletter, v. 15 , no. 2 , p. 4.

Tailleur, I.L., Mamet, B.L., and Dutro, J.T., Jr., 1973, Revised age and structural interpretation of Nuka Formation at Nuka Ridge, northwestern Alaska: American Association of Petroleum Geologists Bulletin, v. 57, no. 7, p. 1348-1352.

Tailleur, I.L. and Sable, E.G., 1963, Nuka Formation of Late Mississippian to Late Permian age, new formation in northern Alaska: American Association of Petroleum Geologists Bulletin, v. 47, no. 4, p. 632-642.

United States Geological Survey, 1973, Possible mantlederived rocks in western Brooks Range, in Geological Survey research 1973: U.S. Geological Survey Professional Paper 850, p. 64-65.

Yoder, H.S., and Tilley, C.E., 1962, Origin of basalt magmas: An experimental study of natural and synthetic rock systems: Journal of Petrology, v. 3, no. 3 , p. 342-532.

Zimmerman, Jay, and Soustek, P.G., 1979, The Avan Hills ultramafic complex, De Long Mountains, Alaska, in Johnson, K.M., and Williams, J.R., eds., The United States Geological Survey in Alaska: Accomplishments during 1978: U.S. Geological Survey Circular 804-B, p. B8-B11. 


\title{
SAMPLE MEDIA USEFUL FOR A SYSTEMATIC GEOCHEMICAL SURVEY OF UPPER VALDEZ CREEK, ALASKA
}

\author{
By \\ Milton A. Wiltse, ${ }^{1}$ Karen H. Clautice, ${ }^{1}$ and Alfred G. Sturmann ${ }^{1}$
}

\section{INTRODUCTION}

The Valdez Creek drainage in the Healy A-1 Quadrangle, Alaska (fig. 1), contains some of the richest placer gravels in North America. The abundance of gold in Valdez Creek gravels indicates that the bedrock source is large. This source has not been conclusively demonstrated, but favored prospect areas include Gold Hill and Lucky Hill in the upper Valdez Creek drainage. These hills are mantled by extensive soliflucted colluvium that locally contains fine-grained $(<0.1-\mathrm{mm})$ gold.

A program of collecting bedrock, vein, and soil samples on a systematic grid and then analyzing for gold and correlated pathfinder elements is one technique that may be effective in identifying bedrock prospects. To enhance the effectiveness of such a geochemical survey, it is helpful to know the trace-element characteristics of the potential sample media. Therefore, our motivation for the present study was to generate information that will be useful in designing a systematic geochemical survey of Gold Hill and Lucky Hill.

Ross (1933) and Tuck (1938), in their early studies of the Valdez Creek district (fig. 1), concluded that there is no correlation between gold and the abundance of trace sulfide minerals (pyrite, arsenopyrite, pyrrhotite, and chalcopyrite) in bedrock and vein material. Their work implied that there should be little correlation between gold and arsenic, copper, or iron. However, later work disclosed significant elemental correlations between gold and silver, arsenic, copper, and zinc in the Timberline Creek drainage a few kilometers west of Gold Hill (Herzberg, 1980). Smith (1981) found significant correlation between gold, silver, and mercury in samples collected from the broader region of the Healy A-1 Quadrangle.

We collected 20 bedrock and 21 vein samples from Gold Hill and Lucky Hill (Wiltse, 1988) for analysis by fire assay-atomic absorption spectrometry (FA-AAS) and by the inductively-coupled plasma-atomic-emissionspectrometry (ICP-AES) technique to determine whether significant gold:metal correlations could be found in analytical data derived from bedrock and vein samples.

\footnotetext{
${ }^{1}$ Alaska Division of Geological and Geophysical Surveys, 794 University
} Avenue, Suite 200, Fairbanks, Alaska 99709-3645.
We also collected samples from B horizons of alpine soils across the trace of the Yellowhorn gold vein located on the north flank of Gold Hill (fig. 1). Because colluvium mantles most hillsides in the area, soil samples are a necessary part of any systematic geochemical exploration survey there.

Soils on the hill sides are immature and it is difficult to consistently identify soil-horizon boundaries. Because of cryoturbation, parent colluvium is relatively homogeneous in each solifluction lobe. However, solifluction lobes from higher elevations overrun those lower on the hillside so that there are primary textural variations in a typical vertical soil profile.

\section{METHODS}

The bedrock sample suite included 20 rock samples that represent the metamorphosed sedimentary rocks and tuffs in the study area and 21 samples of vein material collected from outcrop and slope rubble. Eight 0.5- to 1-kg B-horizon soil samples and eight 4- to 5-kg Bhorizon soil samples [for heavy-mineral concentration (HMC)] were collected from a line of eight test pits in the vicinity of the Yellowhorn gold vein (fig. 1). All sample material was analyzed for trace gold by FA-AAS and for the following elements by ICP-AES after an aqua-regia digestion: $\mathrm{Al}, \mathrm{Ag}, \mathrm{As}, \mathrm{Ba}, \mathrm{Be}, \mathrm{Bi}, \mathrm{Ca}, \mathrm{Cd}, \mathrm{Co}, \mathrm{Cr}, \mathrm{Cu}$, $\mathrm{Fe}, \mathrm{Ga}, \mathrm{Hg}, \mathrm{K}, \mathrm{La}, \mathrm{Mg}, \mathrm{Mn}, \mathrm{Mo}, \mathrm{Na}, \mathrm{Ni}, \mathrm{P}, \mathrm{Pb}, \mathrm{Sb}, \mathrm{Sc}$, $\mathrm{Sr}, \mathrm{Te}, \mathrm{Ti}, \mathrm{Tl}, \mathrm{U}, \mathrm{V}, \mathrm{W}$, and $\mathrm{Zn}$. Aqua-regia digestion of rocks and soils usually results in incomplete liberation of $\mathrm{Al}, \mathrm{Ba}, \mathrm{Ca}, \mathrm{Cr}, \mathrm{Ga}, \mathrm{K}, \mathrm{La}, \mathrm{Mg}, \mathrm{Na} \mathrm{Sr}, \mathrm{Ti}, \mathrm{Tl}$, and $\mathrm{W}$. However, these elements are included in the following statistical analysis because the sample media are similar and the analytical treatment of the samples is uniform. Partial analyses, therefore, are meaningful within the constraints of this study. Trace-element concentrations of $\mathrm{Be}, \mathrm{Cd}, \mathrm{Ga}, \mathrm{Hg}, \mathrm{La}, \mathrm{Pb}, \mathrm{Sb}, \mathrm{Tl}$, and $\mathrm{U}$ were below detection limits in most samples collected or have virtually no geochemical dispersion (Wiltse, in prep.) and so are not considered further in this paper.

Prior to analysis, rock samples were washed to remove contaminating soil and then pulverized to -150 


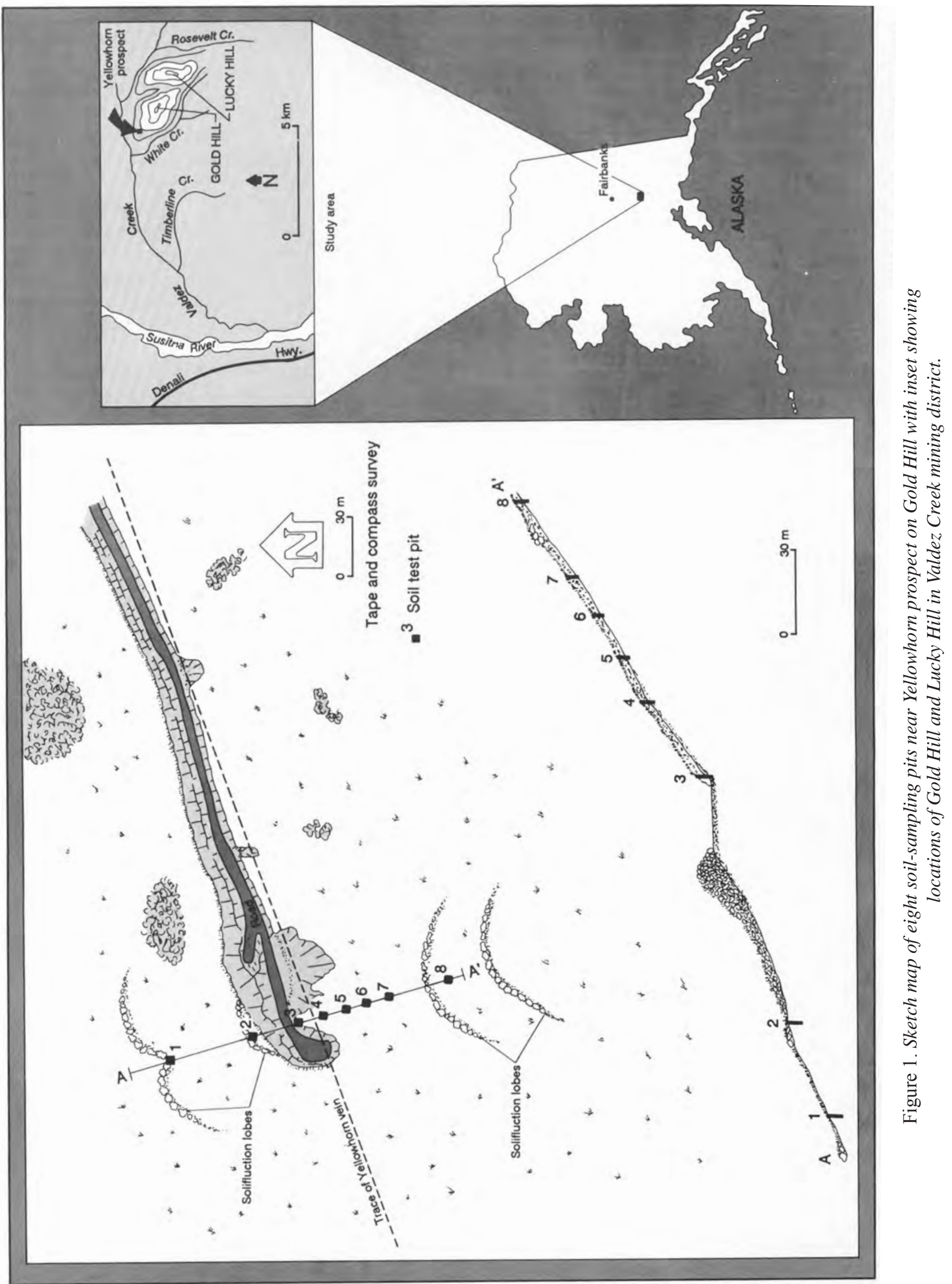


mesh in an agate swing mill. Soil samples were sieved to produce four size fractions: 2 to $0.5 \mathrm{~mm}, 0.5$ to $0.18 \mathrm{~mm}$, 0.18 to $0.063 \mathrm{~mm}$, and $<0.063 \mathrm{~mm}$. Each size fraction was weighed and then pulverized to -150 mesh prior to analysis.

Heavy-mineral soil samples were prepared for analysis by first decanting the $<0.063-\mathrm{mm}$ size fraction and then sieving to extract the 0.5 - to $0.063-\mathrm{mm}$ soil material. Washing the $<0.063-\mathrm{mm}$ size fraction from the sample is effective because of the relatively slow settling rate of $<0.063$-mm-diameter gold particles (Walsh, 1986). To avoid loss of fine-grained gold slightly larger than $0.063 \mathrm{~mm}$, the decant was poured through a $0.063-\mathrm{mm}$ (230-mesh) screen, and retained material was returned to the $>0.063-\mathrm{mm}$ fraction. This process was repeated with clear wash water until the decanted liquid was only slightly cloudy. A size cutoff of $0.063 \mathrm{~mm}$ was used for the HMC because finer grained material is difficult to separate with heavy liquids. The 0.5 - to $0.063-\mathrm{mm}$ size fraction was split in a riffle splitter to obtain about $300 \mathrm{~g}$ of material for subsequent heavy-liquid mineral separation using acetylene tetrabromide (specific gravity $=2.96$ ) The HMC was then pulverized to -150 mesh in an agate swing mill prior to analysis.

Possible correlations between gold and other elements were tested using the Spearman rank-correlation coefficient, $r$ '. This correlation coefficient was chosen instead of the more commonly used Pearsonian product-moment correlation coefficient, $r$, because the sample population is small and some of the data do not have a statistically normal distribution (Rock, 1988).

\section{RESULTS}

Table 1 lists Spearman rank-correlation coefficients of gold with 20 elements in the 20 bedrock and 21 vein samples collected in the Gold Hill and Lucky Hill area. No correlation was calculated for $\mathrm{Ag}, \mathrm{Be}, \mathrm{Bi}, \mathrm{Cd}, \mathrm{Ga}, \mathrm{Hg}$, $\mathrm{La}, \mathrm{Mo}, \mathrm{Pb}, \mathrm{Sb}, \mathrm{Te}, \mathrm{Tl}$, or $\mathrm{U}$ because their concentrations exceeded detection levels in fewer than five samples. If an element correlates in a significantly positive or negative sense with gold at the 95 percent confidence level, the calculated r' for the Au:element pair must exceed the critical value, $r^{\text {** }}$, of the Spearman rank-correlation coefficient. The value of $\mathrm{r}^{* *}$ is a function of the number of element pairs (n) used to calculate r' (Davis, 1986). It is apparent from table 1 that none of the elements listed for rock or vein samples significantly correlates with gold at the 95-percent confidence level. This finding is compatible with the findings of Ross (1933) and Tuck (1938) in the area.

Table 2 lists Spearman rank-correlation coefficients and critical values for gold and 24 elements for each of four size fractions separated from B-horizon soil samples. Review of the r' and r, values demonstrates that there are several elements in each size fraction of soil that significantly correlate with gold. The 0.18 - to $0.063-\mathrm{mm}$ soil fraction has the most pairs of elements showing a significant Au:metal correlation. Figure 2 shows variations in chemical concentrations of gold and significantly correlated elements in the 0.18 - to $0.063-\mathrm{mm}$ soil fraction plotted diagrammatically relative to the pits from which the samples were collected. Pit 3 is located slightly downslope from the projected strike of the Yellowhorn vein (fig. 1). There, the ground surface slopes downward to the north, and the graphs in figure 2 are oriented with north to the left. The maximum peak-tobackground ratio for gold concentrations shown in figure 2 is about $25: 1$.

Figure 3 is a series of box plots for gold concentrations in each of the four soil fractions analyzed. The median value of gold in a soil fraction is represented by the middle bar of the box. The ends of each box include most data values obtained from the eight samples of the given size fraction. Lines extending from the ends of the boxes indicate the extreme range of gold values for a small percentage of samples, and points plotted beyond the ends of the lines are single anomalous values. Velleman and Hoaglin (1981) presented a detailed discussion of the underlying concepts and computations pertinent to box plots. In our study, box plots indicate that all soil fractions contained detectable gold, but the finest size fraction had the highest median concentration of gold. This result is compatible with observations of very fine-grained gold particles visible in soil samples panned in the field.

Table 3 lists Spearman rank-correlation coefficients for gold and 27 elements analyzed in eight HMCs of B-horizon soil samples. It is clear that, in the HMC samples, 16 elements significantly correlate with gold. Figure 4 compares the median and range of gold values in HMC samples and the samples of the four unconcentrated size fractions from soils. In general, analytical values of gold in the HMC of the soil are at least 10 times greater than in any unconcentrated soil fractions.

\section{DISCUSSION OF RESULTS}

\section{Rock ANd Vein SAMples}

Our correlation analysis of the analytical data from rock and vein samples indicates that, for samples subjected to aqua-regia digestion, there is no correlation between gold and other trace elements in Valdez Creek rock and vein material. This lack of significant correlation implies that, among the elements tested in this study using our treatment methods, there are no reliable bedrock pathfinders for gold. In the area investigated, we do not expect 
Table 1. Spearman rank-correlation coefficients ( $\left.r^{\prime}\right)$ and critical values $\left(r^{\prime *}\right)$ indicating correlation between gold and 20 elements analyzed in Gold Hill and Lucky Hill rock and vein samples. $n=$ number of paired analyses. Bold, underlined r'values significant at 95-percent confidence level. $r$ '* from Davis (1986). Analytical data upon which these correlations are based are listed in Wiltse (1988)

\begin{tabular}{|c|c|c|c|}
\hline \multicolumn{4}{|c|}{ Rock } \\
\hline Element & r' & $\mathrm{r}^{\prime *}$ & $\mathrm{n}$ \\
\hline $\mathrm{Al}$ & -.264 & .555 & 13 \\
\hline As & .111 & .636 & 10 \\
\hline $\mathrm{Ba}$ & -.422 & .555 & 13 \\
\hline $\mathrm{Ca}$ & .053 & .555 & 13 \\
\hline $\mathrm{Co}$ & .190 & .555 & 13 \\
\hline $\mathrm{Cr}$ & .147 & .555 & 13 \\
\hline $\mathrm{Cu}$ & .197 & .555 & 13 \\
\hline $\mathrm{Fe}$ & .316 & .555 & 13 \\
\hline K & -.444 & .555 & 13 \\
\hline $\mathrm{Mg}$ & -.111 & .555 & 13 \\
\hline $\mathrm{Mn}$ & .006 & .555 & 13 \\
\hline $\mathrm{Na}$ & -.364 & .555 & 13 \\
\hline $\mathrm{Ni}$ & .171 & .609 & 11 \\
\hline $\mathrm{P}$ & -.419 & .555 & 13 \\
\hline $\mathrm{Sc}$ & -.153 & .580 & 12 \\
\hline $\mathrm{Sr}$ & -.042 & .555 & 13 \\
\hline $\mathrm{Ti}$ & .635 & .683 & 9 \\
\hline $\mathrm{V}$ & -.081 & .555 & 13 \\
\hline W & .202 & .609 & 11 \\
\hline $\mathrm{Zn}$ & -.142 & .555 & 13 \\
\hline
\end{tabular}

\begin{tabular}{|c|c|c|c|}
\hline \multicolumn{4}{|c|}{ Vein } \\
\hline Element & $r^{\prime}$ & $\mathrm{r}^{* *}$ & $\mathrm{n}$ \\
\hline $\mathrm{Al}$ & -.211 & .580 & 12 \\
\hline As & .368 & .580 & 12 \\
\hline $\mathrm{Ba}$ & -.262 & .745 & 7 \\
\hline $\mathrm{Ca}$ & .316 & .580 & 12 \\
\hline $\mathrm{Co}$ & .055 & .580 & 12 \\
\hline $\mathrm{Cr}$ & -.270 & .580 & 12 \\
\hline $\mathrm{Cu}$ & -.098 & .580 & 12 \\
\hline $\mathrm{Fe}$ & .260 & .580 & 12 \\
\hline K & -.110 & .636 & 10 \\
\hline $\mathrm{Mg}$ & .025 & .609 & 11 \\
\hline $\mathrm{Mn}$ & .386 & .580 & 12 \\
\hline $\mathrm{Na}$ & -.067 & .636 & 10 \\
\hline $\mathrm{Ni}$ & -.215 & .636 & 10 \\
\hline $\mathrm{P}$ & -.002 & .580 & 12 \\
\hline $\mathrm{Sc}$ & -.282 & .714 & 8 \\
\hline $\mathrm{Sr}$ & .276 & .580 & 12 \\
\hline $\mathrm{Ti}$ & .263 & .900 & 5 \\
\hline $\mathrm{V}$ & -.594 & .609 & 11 \\
\hline W & . & . & . \\
\hline $\mathrm{Zn}$ & .414 & .414 & 12 \\
\hline
\end{tabular}

to find any of the trace elements analyzed in this study distributed as halos in the rocks surrounding gold sources. Therefore, if an extensive program of lithogeochemical sampling based on analysis for gold by FA-AAS and for trace elements by aqua-regia digestion is conducted in the Lucky Hill-Gold Hill area to locate a bedrock gold source, there is little to be gained by analyzing rock and vein samples for any element but gold. However, other analytical treatments of rock and vein material may produce systematic correlations between gold and some of the elements that were incompletely liberated by our treatments.

\section{Soll SAMPles}

We emphasize that the population of soil samples investigated in this preliminary orientation study is small, and sampling was confined to pits near the Yellowhorn vein. Therefore, caution is required in generalizing the trace-element distributions implied by these data. Regardless, correlation analysis of these preliminary data indicates that, for unconcentrated soil material (table 2 ), the 0.18 - to $0.063-\mathrm{mm}$ soil size fraction contains the greatest number of pathfinder elements that correlate with gold. However, this size fraction does not yield the best median response to the presence of gold in unconcentrated soil (fig. 3). Based on field observations and box plots (fig. 3), it is apparent that considerable gold is contained in the $<0.063-\mathrm{mm}$ soil fraction. However, the $<0.063-\mathrm{mm}$ soil fraction has few elements correlated with gold; for the $<0.063$-mm soil fraction, only silver, molybdenum, and tellurium augment gold data in locating gold-enriched zones. Because pathfinder elements are often more widely dispersed than anomalous gold values, they offer better exploration targets. Thus, the lack of other correlated elements in the $<0.063$-mm soil material is a serious limitation indicating that the finest soil fraction should not be selected as the sample medium for a systematic geochemical soil survey.

As a practical matter, it is time consuming to quantitatively separate $<0.063$-mm material from soil samples or isolate the 0.18 - to $0.063-\mathrm{mm}$ soil fraction. It is desirable to collect a more easily processed soil sample that contains several correlated pathfinder elements and has a high gold-response value. Because sample aliquots of equal size were used to derive our analytical data, a weighted average (based on the weight of each size fraction in the original sample) of elemental concentrations for the two most promising size fractions ( 0.18 to 0.063 $\mathrm{mm}$ and $<0.063 \mathrm{~mm}$ ) should approximate values expected 
Sample Media Useful for a Systematic Geochemical Survey of Upper Valdez Creek

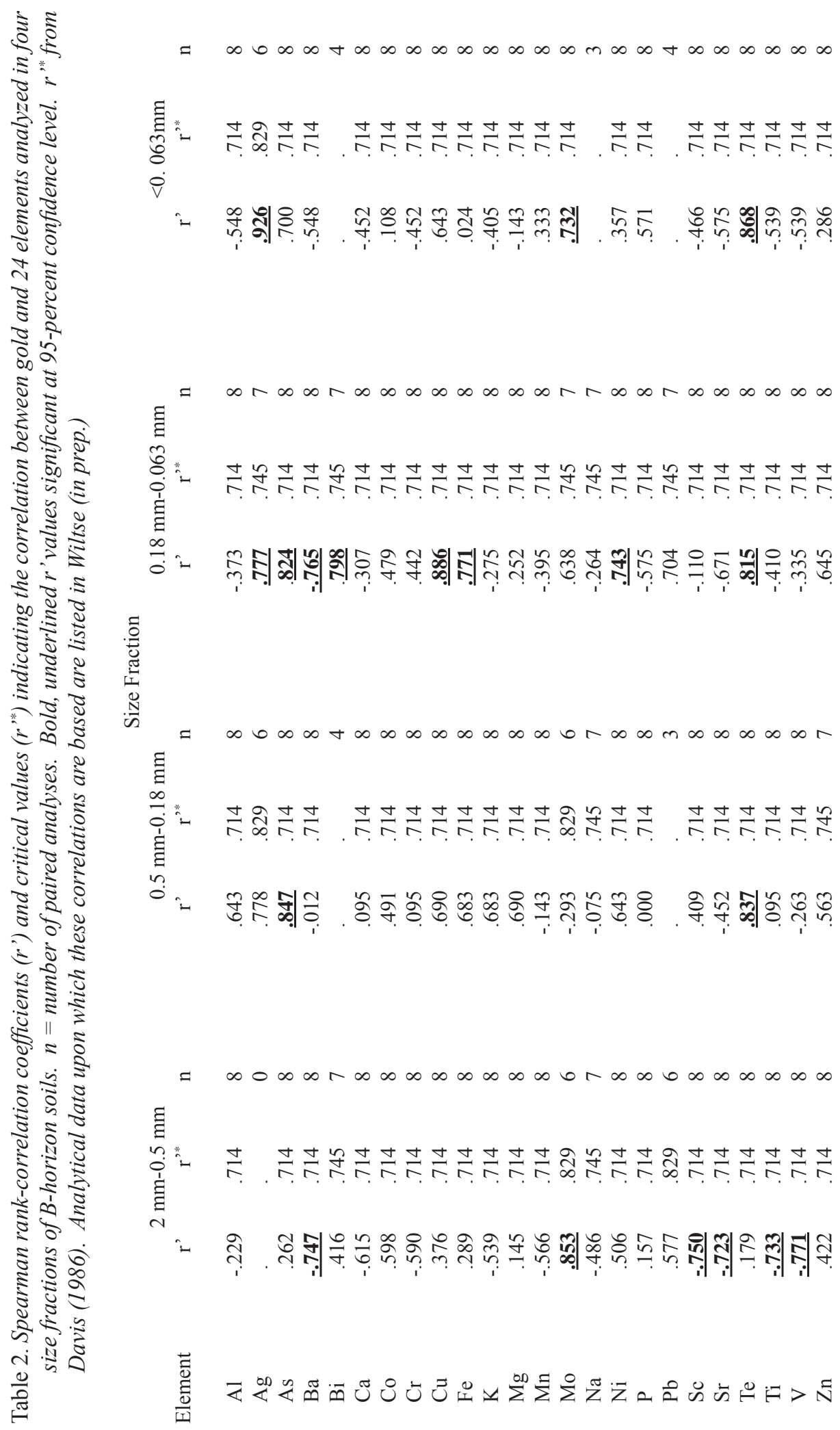



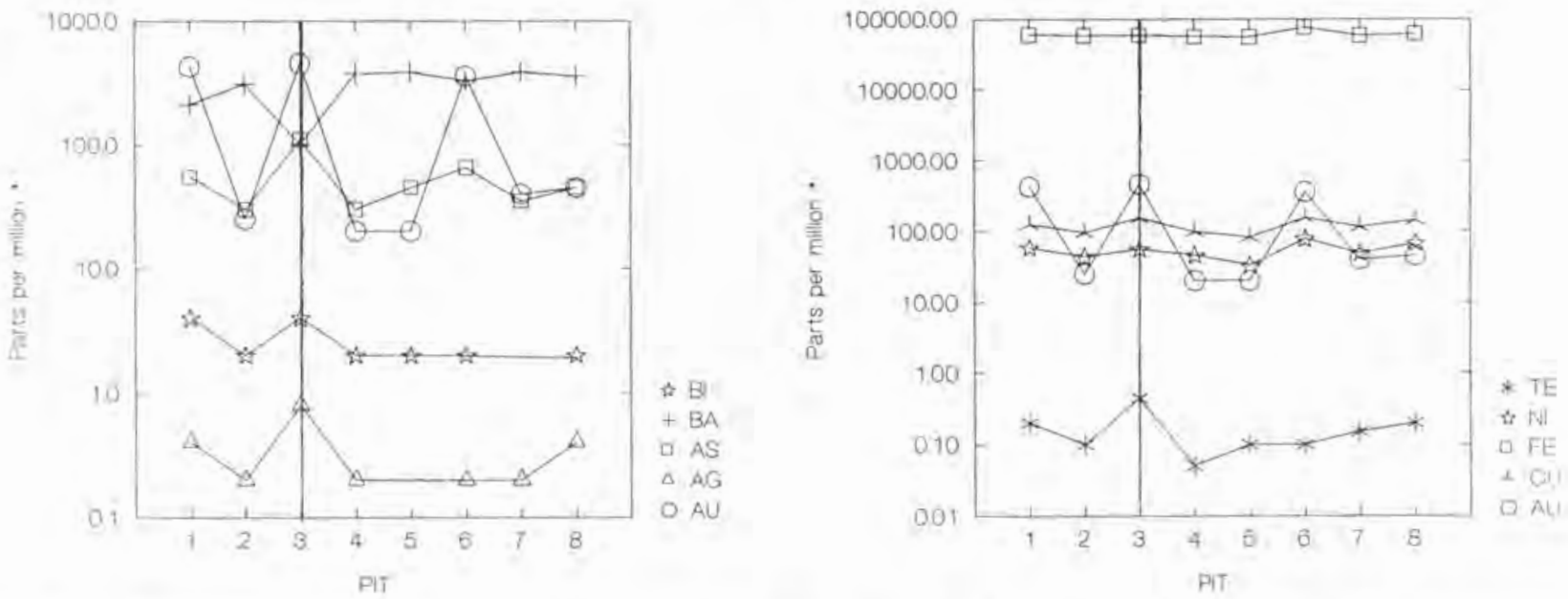

Figure 2. Variations in concentrations of elements significantly correlated with gold (Au) in 0.18- to 0.063-mm size fraction of B soil horizons, Gold Hill-Lucky Hill area. Vertical line represents Yellowhorn vein. * Au in parts per billion. Pits located in figure 1.

from analyzing samples of $<0.18$-mm soil material. At commercial laboratories, the $<0.18$-mm soil fraction is routinely extracted from soils by dry sieving.

Table 4 lists the Spearman rank-correlation values derived from weighted averages of analytical data for the 0.18 - to $0.063-\mathrm{mm}$ and $<0.063-\mathrm{mm}$ soil fractions. Correlation values indicate that four elements correlate significantly with gold in $<0.18$-mm soil material. The

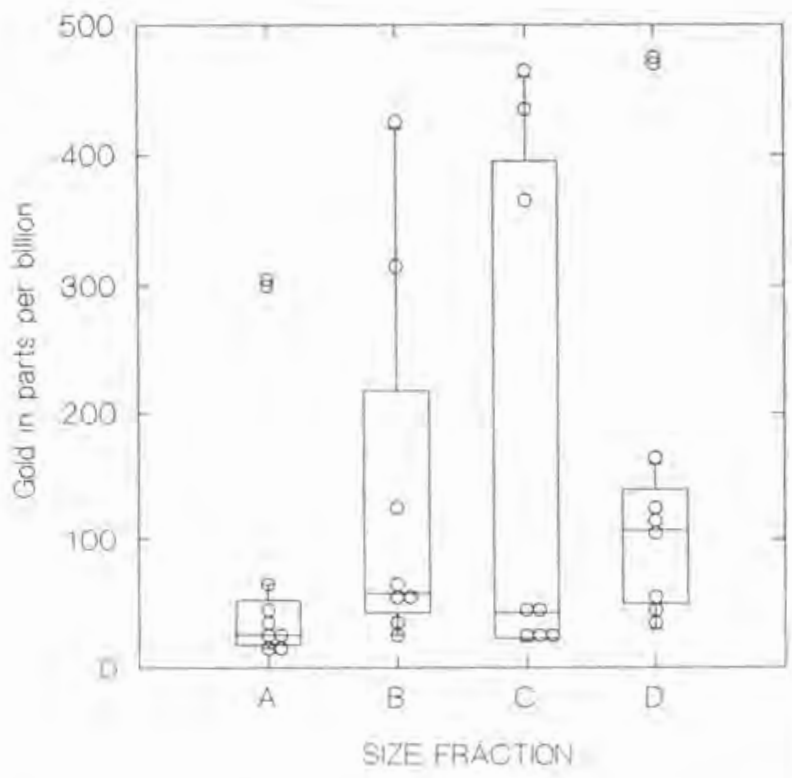

Figure 3. Box plots of gold concentrations in four size fractions of soil horizons collected near Yellowhorn prospect, Gold Hill: $A=2$ to $0.5 \mathrm{~mm}, B=0.5$ to 0.18 $\mathrm{mm}, C=0.18$ to $0.063 \mathrm{~mm}$, and $D=<0.063 \mathrm{~mm}$. $o=$ values of individual samples. box plot of gold concentrations in the original four size fractions and for the weighted average value of the two finest original size fractions shown (fig. 5) indicates that the $<0.18-\mathrm{mm}$ soil fraction provides a reasonably high value for median gold concentration and retains the distribution characteristics of gold in the 0.18 - to $0.063-\mathrm{mm}$ soil fraction. Figure 6 graphically depicts the responses of the four elements $(\mathrm{Cu}, \mathrm{Bi}, \mathrm{As}$, and $\mathrm{Ag})$ that significantly correlate with gold in the weighted average data representing $<0.18-\mathrm{mm}$ soil material. The averaged data indicate that the $<0.18$-mm soil fraction provides an effective sample medium for use in a systematic soil survey of the Gold Hill-Lucky Hill area.

\section{Heavy Mineral Concentrates}

HMC analytical values provide the greatest response of any sample media tested for gold and metallic elements. By removing the diluting effect of light silicate minerals, concentrations are increased for many elements of exploration interest. At higher concentrations of elements associated with heavy-mineral fractions of these soils, there are significant correlations between gold and 16 elements (table 3 ). Although not tabulated here, there are also significant interelement correlations among the metallic elements exclusive of gold. Figure 7 illustrates simultaneous variation in concentration values of gold and significantly correlated elements analyzed in HMC material extracted from Gold Hill soils. The peak-tobackground ratio displayed for gold is about 100:1 in contrast to a peak-to-background ratio for gold of about 25:1 in unconcentrated soil fractions. 
Table 3. Spearman rank-correlation coefficients $\left(r^{\prime}\right)$ and critical values $\left(r{ }^{\prime *}\right)$ indicating the correlation between gold and 27 elements analyzed in heavy-mineral concentrates of B-horizon soil. $n$ = number of paired analyses. Bold, underlined $r$ 'values significant at 95-percent confidence level. $r$ "* from Davis (1986). Analytical data upon which these correlations are based are listed in Wiltse (in prep.)

\begin{tabular}{|c|c|c|c|}
\hline Element & r' & $\mathrm{r}^{*}$ & $\mathrm{n}$ \\
\hline $\mathrm{Al}$ & -.381 & .714 & 8 \\
\hline $\mathrm{Ag}$ & .994 & .714 & 8 \\
\hline As & .762 & .714 & 8 \\
\hline $\mathrm{Ba}$ & .012 & .714 & 8 \\
\hline $\mathrm{Be}$ & .771 & .714 & 8 \\
\hline $\mathrm{Ca}$ &.- .357 & .714 & 8 \\
\hline Co & .833 & .714 & 8 \\
\hline $\mathrm{Cr}$ & -.667 & .714 & 8 \\
\hline $\mathrm{Cu}$ & .833 & .714 & 8 \\
\hline $\mathrm{Fe}$ & .833 & .714 & 8 \\
\hline $\mathrm{K}$ & .347 & .714 & 8 \\
\hline $\mathrm{La}$ & -.577 & .714 & 8 \\
\hline $\mathrm{Mg}$ & .810 & .714 & 8 \\
\hline $\mathrm{Mn}$ & .857 & .714 & 8 \\
\hline Mo & .854 & .714 & 8 \\
\hline $\mathrm{Na}$ & -.964 & .714 & 8 \\
\hline $\mathrm{Ni}$ & .833 & .714 & 8 \\
\hline $\mathrm{P}$ & .690 & .714 & 8 \\
\hline $\mathrm{Pb}$ & .755 & .714 & 8 \\
\hline $\mathrm{Sb}$ & .504 & .714 & 8 \\
\hline $\mathrm{Sc}$ & -.275 & .714 & 8 \\
\hline $\mathrm{Sr}$ & -.838 & .714 & 8 \\
\hline $\mathrm{Te}$ & .826 & .714 & 8 \\
\hline $\mathrm{Ti}$ & $-\overline{.790}$ & .714 & 8 \\
\hline V & -.371 & .714 & 8 \\
\hline W & -.088 & .829 & 6 \\
\hline $\mathrm{Zn}$ & .929 & .714 & 8 \\
\hline
\end{tabular}

Analytical data displayed in figures 4 and 7 indicate that a systematic soil survey of Lucky Hill and Gold Hill that utilizes heavy-mineral concentrates extracted from soil will most reliably identify gold-enriched soils and probably will identify distinct trace-element halos centered on gold-enriched soils. These soil anomalies should be traceable to nearby bedrock sources of mineralization.

\section{CONCLUSIONS}

Fire assay-atomic absorption spectrometry provides a sensitive and effective analytical technique for determining gold in bedrock and vein material in the Lucky Hill and Gold Hill area of the Valdez Creek mining district.

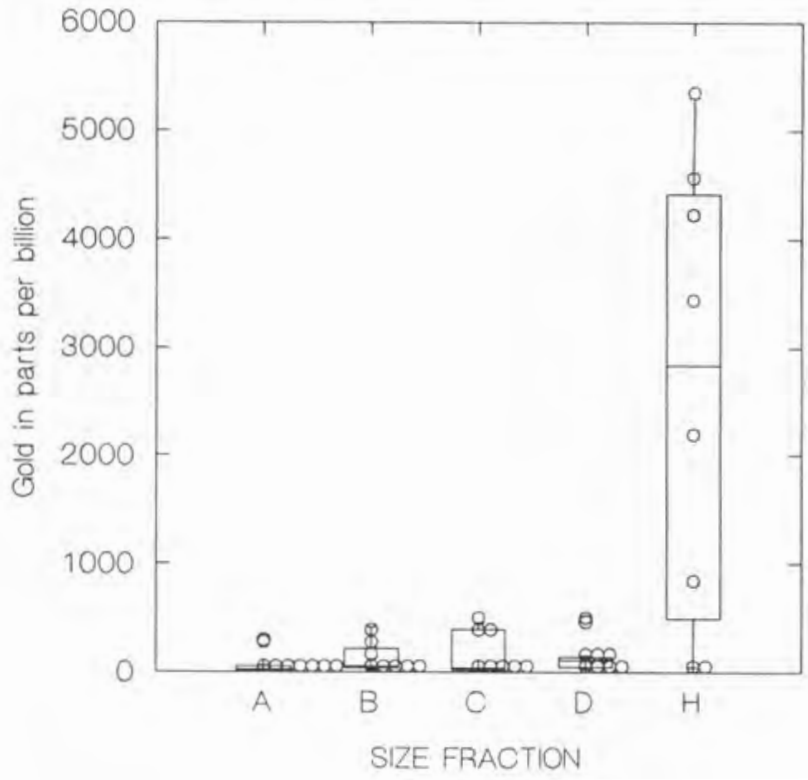

Figure 4. Box plots of gold concentrations in four size fractions of soil and in heavy-mineral concentrates of samples collected near Yellowhorn prospect: $A=2$ to $0.5 \mathrm{~mm}, B=0.5$ to $0.18 \mathrm{~mm}, C=0.18$ to $0.063 \mathrm{~mm}, D=<0.063 \mathrm{~mm}$, and $H=$ heavy mineral concentrates. $o=$ individual sample values.

However, aqua-regia digests of pulverized bedrock and vein material did not yield associated trace-element data that significantly correlated with gold values. Either there is no correlation between gold and other elements in Gold Hill-Lucky Hill bedrock and vein material or digestion of bedrock and vein material by aqua regia is not an effective analytical procedure for extracting these correlations.

The most easily derived unconcentrated soil fraction acceptable for use in a systematic geochemical soil survey is the $<0.18$-mm (-80-mesh) size fraction, which exhibits significant correlation between gold and four pathfinder trace elements $(\mathrm{Cu}, \mathrm{Bi}, \mathrm{As}$, and $\mathrm{Ag})$ and provides anomalous gold concentrations that are sufficiently above analytical detection limits for reliable analysis.

Heavy-mineral concentrates of the 0.5 - to $0.063-\mathrm{mm}$ soil size fraction provided the most responsive sample media tested in this study. Gold concentrations in HMC soil material enhance by about 10 times the gold values in unconcentrated soil material, and the peak-to-background ratio of gold in heavy-mineral concentrates derived from soils is about 100:1 as opposed to about 25:1 in unconcentrated soil fractions. 
Table 4. Spearman rank-correlation coefficients $\left(r^{\prime}\right)$ and critical values $\left(r^{* *}\right)$ indicating the correlation between weighted average values of gold and 24 elements analyzed in $<0.18$ $\mathrm{mm}$ size fractions of B-horizon soils. $n=$ number of paired analyses. Bold, underlined $r$ 'values significant at 95-percent confidence level. $r$ '* from Davis (1986). Analytical data upon which these correlations are based are listed in Wiltse (in prep.)

\begin{tabular}{|c|c|c|c|}
\hline Element & $\mathrm{r}^{\prime}$ & $\mathrm{r}^{\prime *}$ & $\mathrm{n}$ \\
\hline $\mathrm{Al}$ & -.214 & .714 & 8 \\
\hline Ag & .933 & .745 & 7 \\
\hline As & .810 & .714 & 8 \\
\hline $\mathrm{Ba}$ & -.548 & .714 & 8 \\
\hline $\mathrm{Bi}$ & .775 & .745 & 7 \\
\hline $\mathrm{Ca}$ & -.262 & .714 & 8 \\
\hline Co & .071 & .714 & 8 \\
\hline $\mathrm{Cr}$ & -.143 & .714 & 8 \\
\hline $\mathrm{Cu}$ & .738 & .714 & 8 \\
\hline $\mathrm{Fe}$ & .024 & .714 & 8 \\
\hline $\mathrm{K}$ & -.238 & .714 & 8 \\
\hline $\mathrm{Mg}$ & -.095 & .714 & 8 \\
\hline $\mathrm{Mn}$ & .333 & .714 & 8 \\
\hline Mo & .655 & .714 & 8 \\
\hline $\mathrm{Na}$ & -.317 & .714 & 8 \\
\hline $\mathrm{Ni}$ & .571 & .714 & 8 \\
\hline $\mathrm{P}$ & .548 & .745 & 7 \\
\hline $\mathrm{Pb}$ & .393 & .714 & 8 \\
\hline $\mathrm{Sc}$ & -.452 & .714 & 8 \\
\hline $\mathrm{Sr}$ & -.524 & .714 & 8 \\
\hline $\mathrm{Te}$ & .275 & .714 & 8 \\
\hline $\mathrm{Ti}$ & -.333 & .714 & 8 \\
\hline V & -.524 & .714 & 8 \\
\hline $\mathrm{Zn}$ & .357 & .714 & 8 \\
\hline
\end{tabular}

Pathfinder elements that significantly correlate with gold are abundant in the HMC soil fraction of Gold Hill soils and include $\mathrm{Ag}, \mathrm{As}, \mathrm{Be}, \mathrm{Co}, \mathrm{Cu}, \mathrm{Fe}, \mathrm{Mg}, \mathrm{Mn}, \mathrm{Mo}$, $\mathrm{Na}, \mathrm{Ni}, \mathrm{Pb}, \mathrm{Sr}, \mathrm{Te}, \mathrm{Ti}$, and $\mathrm{Zn}$. Therefore, analysis of systematically collected soil HMC samples should identify trace-element halos centered on anomalous soil-gold concentrations.

\section{ACKNOWLEDMENTS}

We thank Thomas D. Light (USGS) and Thomas E. Smith (DGGS) for the many helpful comments made during their review of this paper. Funding for this preliminary study was partially furnished by the U.S. Bureau of Mines.

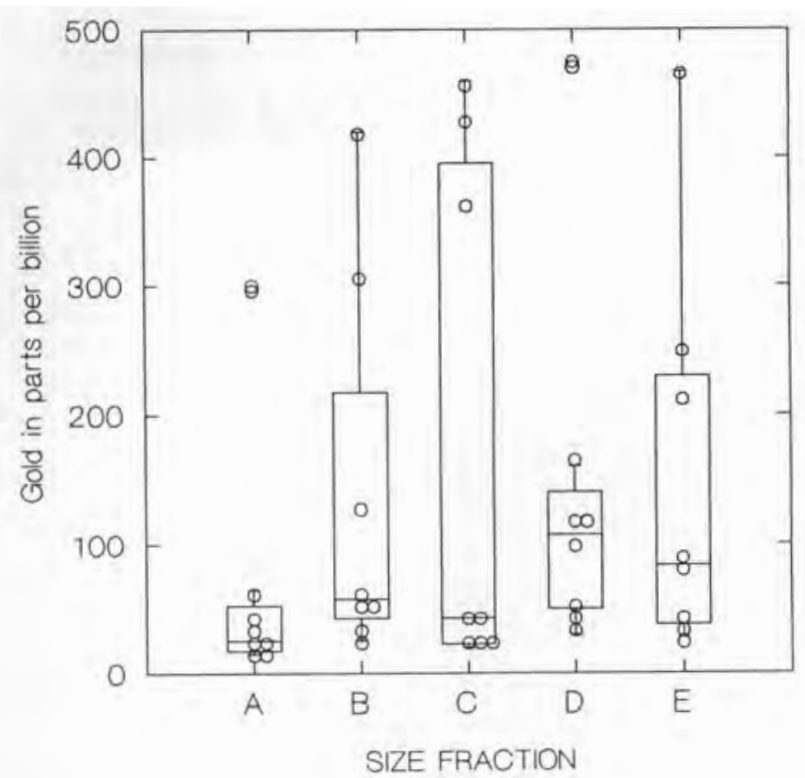

Figure 5. Box plots of gold in four size fractions of soil samples collected near Yellowhorn prospect and weighted average concentrations of gold in $<0.18$ $\mathrm{mm}$ soil fractions: $A=2$ to $0.5-\mathrm{mm}, B=0.5$ to $0.18 \mathrm{~mm}, C=0.18$ to $0.063 \mathrm{~mm}, D=<0.063 \mathrm{~mm}$, and $E=$ weighted average values of $<0.18 \mathrm{~mm}$ size fractions. $o=$ individual sample values.

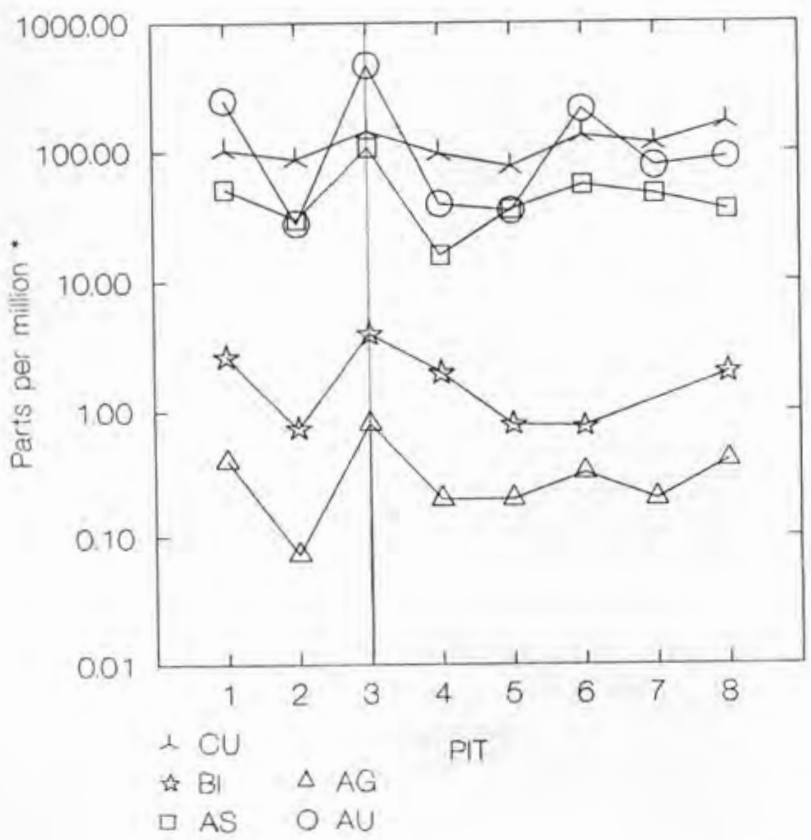

Figure 6. Variations in concentrations of elements significantly correlated with gold (Au) in weighted average analyses of $<0.18-\mathrm{mm}$ soil size fractions. Vertical line represents Yellowhorn vein. ${ }^{*} \mathrm{Au}$ in parts per billion. Pits located in figure 1 . 

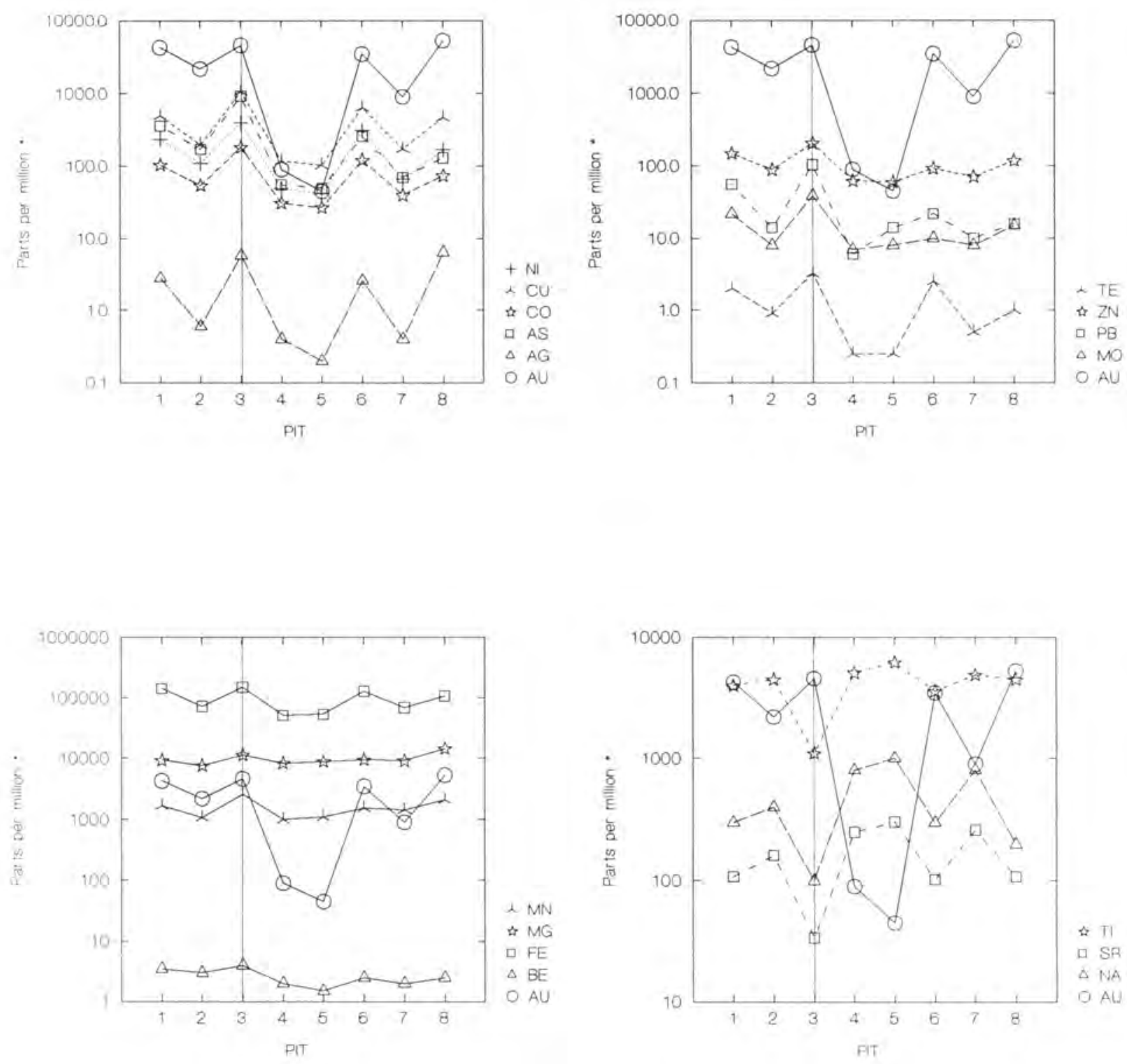

Figure 7. Variations in concentrations of elements significantly correlated with gold (Au) in heavy-mineral concentrates of soils collected near Yellowhorn prospect, Gold Hill. Vertical line represents Yellowhorn vein. * Au in parts per billion. Pits located in figure 1. 


\section{REFERENCES}

Davis, J.C., 1986, Statistics and data analysis in geology: New York, John Wiley and Sons, 646 p.

Herzberg, P.J., 1980, Geology of lode gold occurrences, Timberline Creek area, central Alaska: Fairbanks, University of Alaska M.S. thesis, 120 p., scale 1:9600, 3 sheets

Rock, N.M.S., 1988, Numerical geology: Lecture notes in earth sciences: New York, Springer-Verlag, 427 p.

Ross, C.P., 1933, The Valdez Creek mining district: U.S. Geological Survey Bulletin 849-H, p. 425-468.

Smith, T.E., 1981, Geology of the Clearwater Mountains, south-central Alaska: Alaska Division of Geological and Geophysical Surveys Geologic Report 60, 72 p., scale 1:63,360, 3 sheets.

Tuck, R., 1938, The Valdez Creek mining district, Alaska, in 1936: U.S. Geological Survey Bulletin 897-B, p.109-131.
Velleman, P.F., and Hoaglin, D., 1981, Applications, basics, and computing of exploratory data analysis: Boston, Duxbury Press, 354 p.

Walsh, D.E., 1986, A study of factors suspected of influencing the settling velocity of fine gold particles: Fairbanks, University of Alaska Minerals Industry Research Laboratory final report, U.S. Bureau of Mines Contract 1154102, 75 p.

Wiltse, M.A., 1988, Sample location map, Gold Hill and Lucky Hill, Valdez Creek mining district: Alaska Division of Geological and Geophysical Surveys Public-data File 88-41, scale 1:12,000, 1 sheet.

Wiltse, M.A., in prep., Analytical data for soil samples collected from Gold Hill, upper Valdez Creek, Alaska: Alaska Division of Geological and Geophysical Surveys public-data file. 


\title{
CONTENTS OF PREVIOUS SHORT NOTES ON ALASKAN GEOLOGY
}

\author{
Short Notes on Alaskan Geology-1976: DGGS Geologic Report 51 (out of stock, \$3.50 xeroxed)
}

\author{
Reconnaissance geology along the Variegated Glacier, Saint Elias Mountains \\ Evidence for early Cenozoic orogeny in central Alaska Range \\ The Shumagin-Kodiak batholith: A Paleocene magmatic arc? \\ Speculative tectonic evolution of the Cenozoic Shelikof Trough, south-central Alaska \\ Discovery of blueschists on Kodiak Island \\ Large kaolinite crystals in the Chignik Formation (Upper Cretaceous), Herendeen Bay \\ Occurrence of sodic amphibole-bearing rocks in the Valdez C-2 Quadrangle \\ High-quality coal near Point Hope, northwestern Alaska
}

Short Notes on Alaskan Geology-1977: DGGS Geologic Report 55 (out of stock, \$5.00 xeroxed)

\author{
A Givetian (Late Middle Devonian) fauna from Healy B-4 Quadrangle, central Alaska Range \\ Probable karst topography near Jade Mountains, southwestern Brooks Range \\ Tectonic significance of the Knik River schist terrane, south-central Alaska \\ Geochronology of southern Prince of Wales Island \\ Katmai caldera: Glacier growth, lake rise, and geothermal activity \\ Geology and K-Ar age of mineralized intrusive rocks from the Chulitna mining district, central Alaska \\ The Richardson lineament: A structural control for gold deposits in the Richardson mining district, interior Alaska \\ Boulder Creek tin lode deposits \\ Comparison of mercury-antimony-tungsten mineralization of Alaska with strata-bound cinnabar-stibnite-scheelite \\ deposits of the Circum-Pacific and Mediterranean regions \\ Earthquake recurrence and location in the western Gulf of Alaska
}

Short Notes on Alaskan Geology-1978: DGGS Geologic Report 61 (\$2.00)

Holocene displacements measured by trenching the Castle Mountain fault near Houston

Bluff Point landslide, a massive ancient rock failure near Homer

Recurrent late Quaternary faulting near Healy

Glaciation of Indian Mountain, west-central Alaska

The Cantwell ash bed, a Holocene tephra in the central Alaska Range

Geochronology of metamorphic and igneous rocks in the Kantishna Hills, Mount McKinley Quadrangle

The Chilikadrotna Greenstone, an Upper Silurian metavolcanic sequence in the central Lake Clark Quadrangle

Tectonic and economic significance of Late Devonian and late Proterozoic U-Pb zircon ages from the Brooks Range

Short Notes on Alaskan Geology-1979-80: DGGS Geologic Report 63 (\$1.00)

Lead isotope ratios from the Red Dog and Drenchwater Creek lead-zinc deposits, De Long Mountains, Brooks Range

40K-40Ar ages from rhyolite of Sugar Loaf Mountain, central Alaska Range: Implications for offset along the Hines Creek strand of the Denali fault system

Multiple glaciation in the Beaver Mountains, western interior Alaska

Fossil algae in Lower Devonian limestones, east-central Alaska

Tertiary tillites(?) on the northeast flank of Granite Mountain, central Alaska Range

Evidence for suprapermafrost ground-water blockage, Prudhoe Bay oil field

Short Notes on Alaskan Geology-1982-83: DGGS Professional Report 86 (\$6.00)

An unconformity with associated conglomeratic sediments in the Berners Bay area of southeast Alaska An iron-rich lava flow from the Nenana coal field, central Alaska

Results of shallow seismic survey for ground water at McGrath

Evaluation of a shallow sand-and-gravel aquifer at Eagle River

Correlation of geophysical well logs for a water development in south Anchorage

Garnet compositional estimates as indicators of progressive regional metamorphism in polymetamorphic rocks, Kantishna Hills

Geology of the Miss Molly molybdenum prospect, Tyonek C-6 Quadrangle

Glacial geology of the Mt. Prindle area, Yukon-Tanana Upland 


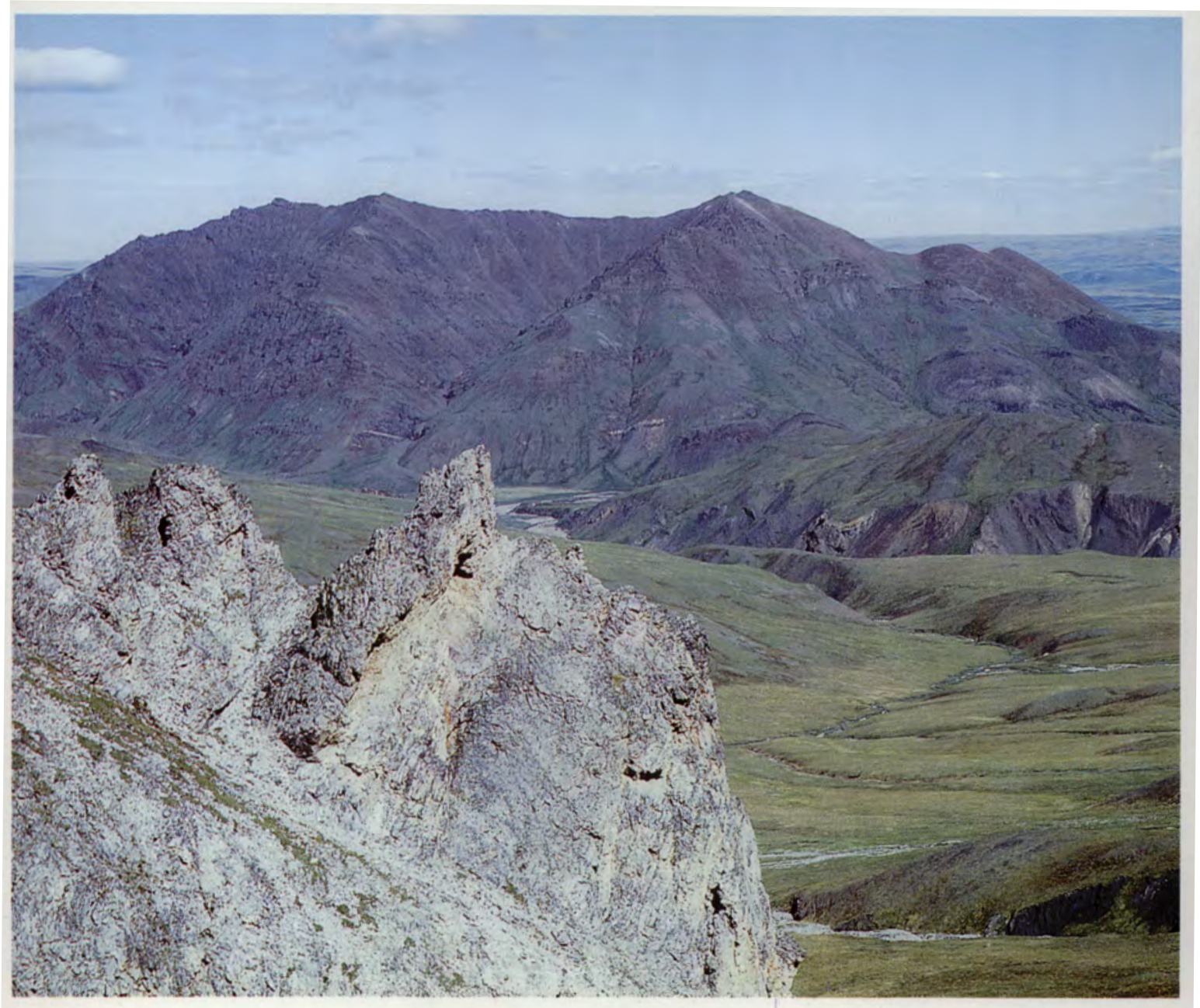

Above: Basalt layers exposed in southwestern flank of Kikiktat Mountain, northcentral Brooks Range. Contact between Kikiktat basalts and underlying Nuka Formation is light-colored zone cropping out of the lower slope near the center of Kikiktat Mountain. Photograph by Charles G. Mull.

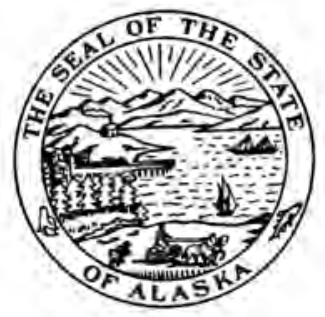

